$$
\text { UNIVERSIDADE DE SÃO PAULO }
$$

FACULDADE DE FILOSOFIA, LETRAS E CIÊNCIAS HUMANAS DEPARTAMENTO DE LETRAS MODERNAS

PROGRAMA DE PÓS-GRADUAÇÃO EM LÍNGUA ESPANHOLA E LITERATURAS ESPANHOLA E HISPANO-AMERICANA

\title{
LAURA SOKOLOWICZ
}

A inclusão da língua espanhola no ensino secundário brasileiro e os primeiros gestos de gramatização: os anos 1920 e a Era Vargas

São Paulo

2020 


\author{
UNIVERSIDADE DE SÃO PAULO \\ FACULDADE DE FILOSOFIA, LETRAS E CIÊNCIAS HUMANAS \\ DEPARTAMENTO DE LETRAS MODERNAS \\ PROGRAMA DE PÓS-GRADUAÇÃO EM LÍNGUA ESPANHOLA E LITERATURAS \\ ESPANHOLA E HISPANO-AMERICANA
}

\title{
A inclusão da língua espanhola no ensino secundário brasileiro e os primeiros gestos de gramatização: os anos 1920 e a Era Vargas
}

Tese de doutorado apresentada ao Programa de Pós-Graduação em Língua Espanhola e Literaturas Espanhola e Hispano-Americana do Departamento de Letras Modernas da Faculdade de Filosofia, Letras e Ciências Humanas da Universidade de São Paulo para a obtenção do título de Doutora em Letras

Orientadora: Profa. Dra. María Teresa Celada

Co-orientadora: Profa. Dra. Elvira Narvaja de Arnoux

São Paulo

2020

Versão corrigida 
Autorizo a reprodução e divulgação total ou parcial deste trabalho, por qualquer meio convencional ou eletrônico, para fins de estudo e pesquisa, desde que citada a fonte.

Catalogação na Publicação

Serviço de Biblioteca e Documentação

Faculdade de Filosofia, Letras e Ciências Humanas da Universidade de São Paulo

\footnotetext{
Sokolowicz, Laura

S683i A inclusão da língua espanhola no ensino secundário brasileiro e os primeiros gestos de gramatização: os anos 1920 e a Era Vargas / Laura Sokolowicz ; orientadora María Teresa Celada ; coorientadora Elvira Narvaja de Arnoux. - São Paulo, 2020 .

$247 \mathrm{f}$.

Tese (Doutorado)- Faculdade de Filosofia, Letras e Ciências Humanas da Universidade de São Paulo. Departamento de Letras Modernas. Área de concentração: Língua Espanhola e Literaturas Espanhola e Hispano-Americana.

1. Ensino e gramatização do espanhol. 2. Arquivo jurídico/legislativo. 3. Anos 1920. 4. Era Vargas. 5. Glotopolítica e Análise do Discurso. I. Celada, María Teresa, orient. II. Arnoux, Elvira Narvaja de, coorient. III. Título.
} 
SOKOLOWICZ, Laura. A inclusão da língua espanhola no ensino secundário brasileiro e os primeiros gestos de gramatização: os anos 1920 e a Era Vargas. Tese apresentada ao Departamento de Letras Modernas da Faculdade de Filosofia, Letras e Ciências Humanas da Universidade de São Paulo para a obtenção do título de doutora em Letras.

Aprovado em: 14/02/2020

\section{Banca examinadora}

Profa. Dra. María Teresa Celada

Instituição: USP

Assinatura:

Profa. Dra. Laura Villa Galán

Instituição: CUNY

Assinatura:

Profa. Dra. Luciana Maria Almeida de Freitas

Instituição: UFF

Assinatura:

Prof. Dr. Adrián Pablo Fanjul

Instituição: USP

Assinatura:

\section{Suplentes}

Profa. Dra.Maria Del Carmen Daher (UFF)

Profa. Dra. Marisa Grigoletto (USP)

Profa. Dra. Fernanda dos Santos C. Rodrigues (USP/UFSCAR) 


\section{ENTREGA DO EXEMPLAR CORRIGIDO DA DISSERTAÇÃO/TESE \\ Termo de Ciência e Concordância do (a) orientador (a)}

Nome do (a) aluno (a): Laura Sokolowicz

Data da defesa: $14 / 02 / 2020$

Nome do Prof. (a) orientador (a): María Teresa Celada

Nos termos da legislação vigente, declaro ESTAR CIENTE do conteúdo deste EXEMPLAR CORRIGI DO elaborado em atenção às sugestões dos membros da comissão Julgadora na sessão de defesa do trabalho, manifestando-me plenamente favorável ao seu encaminhamento e publicação no Portal Digital de Teses da USP.

São Paulo, 27/03/2020

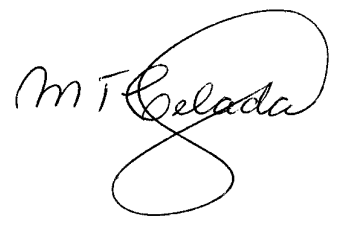

María Teresa Celada - orientadora 
A Susi e Soko, novamente, por muitas outras coisas 


\section{AGRADECIMENTOS}

À minha orientadora, Maite Celada pelas numerosas e cuidadosas leituras, releituras e reformulações, pela dedicação, confiança e incentivo. À minha co-orientadora, Elvira Narvaja de Arnoux, pelas conversas nos "despachos” de Buenos Aires, pelas continuas observações e sugestões, pela cuidadosa leitura final. Maite e Elvira, a vocês duas agradeço os riquíssimos aprendizados de todos estes anos.

À Fernanda Castelano Rodrigues e ao Adrián Fanjul, pela leitura atenta da qualificação e pelas observações, críticas e sugestões trazidas naquela jornada de trabalho. Também agradeço pelas contribuições na minha formação ao longo de todos esses anos.

Ao Núcleo de Documentação e Memória do Colégio Pedro II (NUDOM), especialmente à Elizabeth, pela acolhida, a disponibilização de materiais e o apóio constante durante a pesquisa no Núcleo.

À Luciana Freitas, por compartilhar o seu arquivo de instrumentos linguísticos e ao Anselmo Guimarães, pela disposição com que atendeu as diversas consultas.

Aos amigos historiadores Rita Sampaio, André Motta e Tânia Garcia pelas interlocuções, a indicação de bibliografia e as conversas sobre fragmentos da história do Brasil. Ao André, agradeço também a leitura crítica da primeira parte da tese.

Às novas amizades que a vida acadêmica me trouxe em Buenos Aires, Daniela Lauría e Magui López García, pelas leituras, interlocuções, pela constante indicação e envio de bibliografia, pela enorme generosidade.

À Larissa, Bruna, Aninha e Michele, pelo apoio e carinho e por me resgatar em muitas oportunidades do entremeio das línguas. A Rô Dantas, pelos livros da UNIFESP, pelo afeto e o apoio e a Natália Victuri, pela constante colaboração com questões das mais diversas.

Aos amigos queridos, pelo apoio, as risadas e as conversas, pela proximidade que sempre acalma, agradeço à Fernanda, à Ana Cláudia, à Nati e à Karin, à Joana e ao Cláudio e muito especialmente à Anita, pelo apoio constante, pelas diversas leituras e interlocuções em meio de tantas coisas.

À Luciene, pela simpática, alegre e afetuosa proximidade em parte da reta final.

À Fabi Paiva, agradeço especialmente pela ajuda na diagramação e montagem.

Finalmente, à minha família querida, Susi, Rá, Ale, Juancito, Soki, pela proximidade apesar da distância e pelo apoio e carinho que isso significa.

O presente trabalho foi realizado com apoio da Coordenação de Aperfeiçoamento de Pessoal de Nível Superior (CAPES) - código de financiamento 001. 
SOKOLOWICZ, Laura. A inclusão da língua espanhola no ensino secundário brasileiro e os primeiros gestos de gramatização: os anos 1920 e a Era Vargas. Tese (doutorado) - Faculdade de Filosofia, Letras e Ciências Humanas, Universidade de São Paulo, 2020.

Por meio da análise de dois arquivos principais que funcionam como lugares de memória, o jurídico/legislativo e o dos instrumentos linguísticos que gramatizam o espanhol, esta tese se debruça sobre a inclusão dessa língua na educação básica em dois períodos importantes da historia do Brasil: os anos 1920 e a Era Vargas. Estudam-se as diferentes dinâmicas que em cada um dos momentos históricos selecionados marcaram tal inclusão: pontual no primeiro, com a incorporação da língua como disciplina facultativa no Colégio Pedro II (1920-1925) e com a produção de um único instrumento linguístico para seu ensino, a Gramática de espanhol para uso dos brasileiros, de Antenor Nascentes, e mais expandida no segundo pela ampliação do ensino médio e a inclusão do espanhol como disciplina obrigatória nesse âmbito escolar (1942-1961) como efeito das diretrizes da Reforma Capanema (1942). Essa ampliação produziu uma aceleração na produção editorial, da qual mapeamos certas regularidades e selecionamos o Manual de espanhol (1945), de Idel Becker e as reformulações produzidas pelo próprio autor para um estudo mais aprofundado. A partir de uma perspectiva glotopolítica e do dispositivo da análise de discurso materialista e da história das ideias linguísticas, observam-se mudanças e permanências à luz das transformações das conjunturas políticas, sociais, econômicas e educativas. Mudanças e permanências que permitem acompanhar a construção de uma memória discursiva sobre a língua na escola. Nossas conclusões apontam que um dos aspectos que afeta o movimento de inclusão/exclusão da língua e o tipo de inclusão estaria vinculado às diferentes posições que o Brasil assumiu nas relações internacionais com os Estados Unidos e com os países da América Latina e ao lugar outorgado aos países vizinhos no tabuleiro político. Como efeito, a inclusão da língua no primeiro período se mostrou "tímida" (breve e facultativa), e mais potente (com a obrigatoriedade e a longa permanência) na Era Vargas. Nesse segundo período, as alianças políticas e comerciais com os países da região e as missões culturais outorgaram à língua uma dimensão política que projetava sua contribuição para uma "maior e mais íntima vinculação espiritual com as nações irmãs do continente". Com relação ao processo de gramatização da língua, a pesquisa permitiu identificar na Real Academia Espanhola e nos instrumentos linguísticos produzidos por essa instituição uma matriz de sentidos. Se na Gramática de Nascentes observamos uma ampla adesão a esse dispositivo normativo, embora com estreitas fissuras por onde surgem suaves pinceladas sobre a diversidade da língua e as controvérsias que a habitam, no Manual de espanhol identificamos deslizamentos que, ampliando as fissuras do discurso hegemônico, dão à diversidade e às controvérsias maior visibilidade. Finalmente, vale assinalar que a realização da pesquisa permitiu observar que as biografias de Nascentes e Becker, autores estudados em cada período, parecem condensar questões e tensões de época, relevantes em termos das relações que podem ser estabelecidas entre os lugares sociais que ocupavam e as posições que se materializam na realização das respectivas obras.

Palavras-chave: arquivo jurídico/legislativo, gramatização brasileira do espanhol, ensino secundário, memória discursiva, anos 1920, Era Vargas. 


\begin{abstract}
SOKOLOWICZ, Laura. The addition of the Spanish language in the Brazilian secondary school and the first grammatization initiatives: the 1920s and the Vargas years. Tese (doutorado) - Faculdade de Filosofia, Letras e Ciências Humanas, Universidade de São Paulo, 2020.
\end{abstract}

Through analyzing two main files that work as memory places, the legal/legislative and the linguistic instruments that make the grammatization of the Spanish language, this thesis addresses the insertion of this language in basic education in two important periods in Brazilian history: the 1920s and the Vargas years. Different dynamics that marked this insertion in each of these historical moments selected are studied: specific at the first one, incorporating the language as an optional subject at Colégio Pedro II (1920-1925) and with the production of a single linguistic instrument for teaching it, the Gramática de espanhol para uso dos brasileiros, by Antenor Nascentes, and broader in the second one, because of the expansion of secondary education and the addition of the language as a compulsory subject in this educational area (1942-1961) as an effect of the guidelines in the Reforma Capanema (1942). This expansion produced an acceleration in editorial production, in which we mapped certain regularities and selected the Manual de espanhol (1945), by Idel Becker and the reformulations produced by the author himself for a deeper study. From a glotopolytics, materialistic discourse analysis device and history of linguistic ideas perspective, changes and continuities are observed, in the light of the changes in political, social, economic and educational circumstances. Changes and continuities that allow to track the construction of a discursive memory about the language in school. Our conclusions indicate that one of the aspects that affects the inclusion/exclusion movement of the language and the kind of inclusion would be linked to the different positions that Brazil took on international relations with the United States and with Latin American countries and the given position to neighboring countries in the political stage. As an effect, the addition of the language in the first period was "timid" (brief and optional), and more potent (being compulsory and long remaining) in the Vargas years. In the second period, political and commercial alliances with regional countries and cultural missions gave a political dimension to the language that projected its contribution to a "bigger and closer spiritual connection with the continent sister nations”. In relation to the grammatization process of the language, this research allowed to identify in the Spanish Royal Academy and the linguistic instruments produced by these institutions a senses matrix about the language. If on the Gramática by Nascentes we observe a wide adhesion to this normative device, although with thin fissures through which soft strokes on the diversity of the language and the controversies that inhabit it arise, on the Manual de espanhol we identify slips that, broadening the fissures of the hegemonic discourse, give more visibility to the diversity and controversies. Finally, it is worth to point out that the conducting of this research revealed that Nascentes and Becker's biographies, studied authors in each period, seem to condensate matters and tensions of each period, relevant in terms of relations that can be established between social status occupied by them and the positions materialized in the accomplishment of the respective works.

Key words: legal/legislative file, Brazilian grammatization of the Spanish language, secondary school, discursive memory, 1920s, Vargas years. 
RESUMEN

SOKOLOWICZ, Laura. La inclusión de la lengua española en la enseñanza secundaria brasileña y los primeros gestos de gramatización: los años 1920 y la Era Vargas. Tese (doutorado) - Faculdade de Filosofia, Letras e Ciências Humanas, Universidade de São Paulo, 2020.

Por medio del análisis de dos archivos principales que funcionan como lugares de memoria, el jurídico/legislativo y el de los instrumentos lingüísticos que gramatizan el español, esta tesis estudia la inclusión de esa lengua en la enseñanza secundaria en dos períodos importantes de la historia de Brasil: los años 1920 y la Era Vargas. Se analizan las diferentes dinámicas que en cada uno de los dos momentos históricos seleccionados marcaron tal inclusión: puntual en el primero, con la incorporación de la lengua como materia optativa en el Colegio Pedro II (1920-1925) y con la producción de un único instrumento lingüístico para su enseñanza, la Gramática de espanhol para uso dos brasileiros, de Antenor Nascentes, y más expandida en el segundo por la ampliación de la enseñanza media y la inclusión del español como materia obligatoria en ese ámbito escolar (1942-1961) como efecto de las directrices de la Reforma Capanema (1942). Esa ampliación produjo una aceleración en la producción editorial, de la que mapeamos ciertas regularidades y seleccionamos el Manual de espanhol (1945), de Idel Becker y las reformulaciones producidas por el propio autor para un estudio más específico. A partir de una perspectiva glotopolítica y del dispositivo del análisis de discurso materialista y de la historia de las ideas lingüísticas, se observan cambios y permanencias, a la luz de las transformaciones de las coyunturas políticas, sociales, económicas y educativas. Cambios y permanencias que permiten acompañar la construcción de una memoria discursiva sobre la lengua en la escuela. Nuestras conclusiones señalan que uno de los aspectos que afecta el movimiento de inclusión/exclusión de la lengua y el tipo de inclusión estaría vinculado a las diferentes posiciones que Brasil asumió en las relaciones internacionales con los Estados Unidos y con los países de América Latina y al lugar otorgado a los países vecinos en el tablero político. Como efecto, la inclusión de la lengua en el primer período se mostró "tímida" (breve y optativa), y más potente (con la obligatoriedad y la larga permanencia) en la Era Vargas. En este segundo período, las alianzas políticas y comerciales con los países de la región y las misiones culturales le dieron a la lengua una dimensión política que proyectaba su contribución para una "mayor y más íntima vinculación espiritual con las naciones hermanas del continente”. Con relación al proceso de gramatización de la lengua, la investigación permitió identificar en la Real Academia Española y en los instrumentos lingüísticos producidos por esa institución una matriz de sentidos. Si en la Gramática de Nascentes observamos una amplia adhesión a ese dispositivo normativo, aunque con estrechas fisuras por donde surgen suaves pinceladas sobre la diversidad de la lengua y las controversias que la habitan, en el Manual de espanhol identificamos deslizamientos que, ampliando las fisuras del discurso hegemónico, le dan a la diversidad y a las controversias mayor visibilidad. Finalmente, vale señalar que la realización de la investigación permitió observar que las biografías de Nascentes y de Becker, los autores estudiados en cada período, parecen condensar cuestiones y tensiones de época, relevantes en términos de las relaciones que se pueden establecer entre los lugares sociales que ocupaban y las posiciones que se materializan en la realización de las respectivas obras.

Palabras clave: archivo jurídico/legislativo, gramatización brasileña del español, enseñanza secundaria, memoria discursiva, años 1920, Era Vargas. 
INTRODUÇÃO $\quad \mathbf{1 0}$

1. Contexto de partida e novas indagações $\quad 12$

2. Recorte do objeto e justificativa 17

3. Articulação teórico-analítica 20

4. Estrutura da tese $\quad 22$

CAPÍTULO 1

A inclusão da língua no Colégio Pedro II e a produção da Gramática de Nascentes

1. Relações internacionais: Brasil, Estados Unidos e “a outra América Latina” 30

2. O autor: biografia, filiações teóricas e trajetória intelectual 42

3. Circulação de saberes: tradição e memória 49

3.1. A Gramática numa série plurilíngüe $\quad 50$

3.2. As fontes e a "unidade” da língua 60

\section{CAPÍTULO 2}

Debates e disputas no campo linguístico e os efeitos

na produção da Gramática

1. Norma e língua nacional nos anos $1920 \quad 67$

1.1. Nascentes e o estatuto da língua portuguesa do/no Brasil 71

1.2. O Linguajar Carioca (1922): ideologia dominante e construção de um 73

dizer próprio

$\begin{array}{ll}\text { 1.2.1. Leitores e leituras } & 74\end{array}$

1.2.2. Aproximações e afastamentos do discurso dominante 81

2. Língua e norma na Gramática $\quad 84$

2.1. Enraizamento em uma norma central $\quad 86$

$\begin{array}{ll}\text { 2.1.1. A RAE e a variedade central } & 87\end{array}$

2.1.2. Espanha e "os espanhóis” 97

2.2. Outros dizeres e controvérsias 101

$\begin{array}{ll}\text { CAPÍTULO } 3 & 106\end{array}$

A entrada do espanhol no currículo na Era Vargas e a expansão do mercado editorial

1. Exposição de Motivos e Reforma Capanema: um programa político e um projeto nacional de educação

2. Programa de espanhol dos cursos clássico e científico: representações ampliadas $\quad 129$

3. Um mercado editorial em expansão: a produção acelerada de livros de 133 espanhol

4. Idel Becker: aspectos biográficos e representações sobre a língua espanhola 
Reformulação interdiscursiva: as três versões do Manual de espanhol (1945, 1947, após 1961)

1. Gênero e organização: a reformulação composicional e os destinatários 156

2. Os paratextos: da palavra própria à palavra alheia 160

2.1. Menéndez Pidal e a carta encaminhada a Idel Becker 166

2.2. Rodó e o texto América 172

3. As tensões históricas: entre uma norma central e a diversidade lingüística $\quad 177$

4. As lições preliminares: o contraste entre as línguas 192

5. As leituras iniciais das lições: Espanha e Hispano-américa 194

5.1. O primeiro bloco de leituras: Espanha e a formação pedagógica e moral 196

5.2. O segundo bloco de leituras: Hispano-américa 201

6. Os provérbios: projeção e interpelação do destinatário 204

7. Os exercícios: o papel das línguas e dos tópicos gramaticais 208

8. As notas explicativas da primeira versão: o que se apaga na redução 212

CONSIDERAÇÕES FINAIS E PROJEÇÕES 
INTRODUÇÃO 
(...) algo no plano dos sentidos se realiza de forma independente das políticas linguísticas e suas legislações. Bethania Mariani e Vanise Medeiros, 2007

Esta pesquisa discute aspectos da inclusão da língua espanhola no ensino secundário e os efeitos no seu processo de gramatização - a elaboração de gramáticas e manuais - no espaço de enunciação brasileiro. Analisam-se essas problemáticas em dois períodos fundamentais. O primeiro é o dos anos 1920, por concentrar três acontecimentos inaugurais: a entrada do espanhol no Colégio Pedro II como disciplina facultativa (de 1920 a 1925), o primeiro concurso para ocupar a vaga de professor de espanhol nessa escola e a produção da primeira gramática para o ensino da língua. O segundo período corresponde à Era Vargas, quando o espanhol é incluído como disciplina obrigatória no currículo dos cursos “clássico” e “científico”, medida que permanece vigente entre 1942 e 1961. Essa inclusão no sistema educativo produz uma aceleração na produção editorial, que vê nesses anos o surgimento de diversas gramáticas, antologias e manuais. São, portanto, dois momentos significativos da história da língua espanhola no Brasil, de par com importantes transformações na história do próprio país. Como dois momentos políticos, sociais e educativos diversos, com projetos de país também diferentes, produzem dinâmicas diversas no processo de inclusão da língua e na conseqüente produção de instrumentos linguísticos.

Propõe-se como objetivo geral rastrear e interpretar a rede complexa de condições de produção que, nesses dois períodos da história do país, produziu efeitos na circulação da língua espanhola em diferentes âmbitos educativos, na elaboração de instrumentos linguísticos e nas representações e discursos que foram construindo a memória sobre a língua. Assim, interrogamos a história e a construção de uma memória discursiva sobre a língua espanhola e seu processo de gramatização ${ }^{1}$ à luz das transformações das conjunturas históricas, com especial atenção, por um lado, às relações internacionais que o Brasil estabelece fundamentalmente com os Estados Unidos e com os países da América Latina e,

\footnotetext{
1 Tomamos esse conceito de Auroux ([1992] 2009a), com a ressignificações e ampliações propostas por Orlandi (2001) e Arnoux (2016).
} 
por outro, aos debates e disputas em torno das línguas e dos processos que na elaboração de instrumentos linguísticos vão vinculando o espanhol a um determinado dispositivo normativo.

Em síntese, busca-se compreender como as tramas políticas desses dois períodos históricos específicos afetam o devir dos acontecimentos mencionados. Um dos interesses fundamentais da pesquisa é identificar nos materiais selecionados indícios dos processos históricos e, ao mesmo tempo, as marcas que permitam mapear regularidades, continuidades, descontinuidades e transformações. Para tanto, tomam-se os instrumentos linguísticos como objetos discursivos que se, por um lado, deixam rastros da construção de uma memória sobre a língua estrangeira (projetando representações sobre ela e seu ensino), também permitem entrever as disputas dos saberes em jogo e os processos de seleção e exclusão que, a partir de um determinado dispositivo normativo, vinculam a língua a um padrão linguístico. Entendendo a língua como um campo ideológico de controvérsias, busca-se dar visibilidade às dimensões histórica e política que atravessam a sua circulação e a produção e circulação de instrumentos linguísticos. Dimensões que nos levam a formular algumas indagações iniciais nas quais ressoam os dois planos lançados pela epígrafe desta apresentação: quais são as pistas que permitem compreender as motivações governamentais para a inclusão da língua em cada um desses recortes históricos e como as mesmas se manifestam? E que língua se projeta imaginariamente ao longo da história desse processo, quais as tensões detectadas e como entram em jogo os processos políticos mais amplos?

\section{Contexto de partida e novas indagações}

Fernand Braudel, o historiador francês, escreveu que “a história não é mais do que uma constante interrogação sobre o tempo passado em nome dos problemas e curiosidades e até das inquietações e das angústias - do tempo presente que nos rodeia e nos perturba” $(1987)^{2}$. Essa frase indica de certo modo as inquietações que deram origem a esta pesquisa.

Como ponto de partida, o trabalho toma indagações surgidas no decantar das reflexões desenvolvidas na dissertação de mestrado (Sokolowicz, 2014), permitindo abrir outras dimensões de pesquisa, leitura e interpretação que ampliam o conhecimento já

\footnotetext{
${ }^{2}$ Da apresentação do livro do autor: O mediterrâneo: o espaço e a história, sem numeração de páginas
} 
produzido sobre aspectos da história, da memória e do processo de gramatização do espanhol no Brasil, estudado à luz das diversas conjunturas sócio-históricas de produção.

Naquela pesquisa estudamos o processo de gramatização da língua espanhola no Brasil numa temporalidade recente - a última década do século XX e a primeira do XXI -, colocando em revista a produção e circulação de livros didáticos. Um campo com sentidos naturalizados, tensões, disputas, hegemonias e contradições no qual trabalhamos sobre a dimensão política implicada no processo de gramatização da língua. Reunir e interpretar acontecimentos dispersos e diversos nos permitiu comprovar a potência e a importância de estudar a produção e circulação de instrumentos linguísticos à luz das conjunturas políticas, sociais, econômicas, culturais e educativas, permitindo deste modo rastrear as diversas formas em que o extralinguístico (a história) se faz materialmente presente no linguístico. Em outras palavras, os diversos modos como os materiais nos remetem às condições de produção e a trajetos de uma memória discursiva. Foi a partir dessa constatação que objetivamos dar sequência ao estudo da gramatização do espanhol como língua estrangeira no Brasil, ampliando a temporalidade, o corpus e as problemáticas, e aprofundando a análise histórica, discursiva e ideológica de tal processo com esse retorno à primeira metade do século XX.

Decantadas as ideias dessa pesquisa, surgiram novas indagações. Três aspectos específicos pareciam nodais, configurando “problemas”, “curiosidades” e “até inquietações” para retomar as palavras de Braudel -, que nos levaram ao passado para tentar compreendêlos criticamente. Foi esse voltar-nos à história o que deu forma e fundamento à pesquisa aqui desenvolvida, permitindo delimitar os objetos de estudo e formular as hipóteses iniciais. Os três aspectos disparadores das interrogações iniciais são os seguintes:

(1) Ao estudar a última década do século XX e a primeira do XXI identificamos uma presença intensificada (e até naturalizada) de ideias linguísticas vinculadas a uma matriz de sentidos espanhola que projeta representações específicas sobre a língua e seu ensino. Na pesquisa de mestrado, constatamos que a chegada do Instituto Cervantes ao Brasil, em 1998, como parte da proliferação de projetos que buscavam promover o status do espanhol internacionalmente, para além das fronteiras da Espanha (Del Valle, 2005) e a entrada massiva de instrumentos linguísticos produzidos naquele país a partir dos anos noventa ${ }^{3}$ foram acontecimentos que intensificaram a circulação dessa matriz

\footnotetext{
${ }^{3}$ Pensamos especialmente em livros didáticos para o ensino da língua.
} 
de sentidos $^{4}$ e a reativação da política pan-hispânica ${ }^{5}$, com efeitos na projeção de representações sobre a língua e seu ensino.

A partir dessa constatação nos perguntamos sobre presenças anteriores ou, em termos discursivos, sobre lugares de memória (Nora, 1993) ${ }^{6}$ : em que medida poderíamos reconhecer essa matriz de sentidos em outros momentos e materialidades, favorecendo, por um processo de repetibilidade - mesmo com "disjunções e deslocamentos”, como diria Pêcheux (2010a, p. 56) - essa posterior naturalização? Avançando no estudo e já trabalhando sobre o corpus identificamos outros acontecimentos, mais silenciosos e talvez menos visíveis que os referidos acima, que funcionando como vestígios dessa matriz peninsular de sentidos nos levaram a formular a hipótese de que a valorização de uma tradição linguística espanhola estaria presente em diversos momentos do século XX, afetando de forma heterogênea o processo de gramatização da língua e, por tanto, o jogo de representações projetadas em instrumentos linguísticos chaves na história do ensino de espanhol no Brasil como os estudados neste trabalho: a Gramática de espanhol para uso dos brasileiros de Antenor Nascentes (1920) e o Manual de Espanhol de Idel Becker (1945).

(2) O segundo aspecto - entrelaçado ao anterior - parte de certas tensões já detectadas naquela pesquisa, presentes nas relações que podem ser estabelecidas entre a política linguística explícita do Estado - leis, decretos, projetos de leis, reformas - e a produção de instrumentos linguísticos como instância fundamental do processo de gramatização do espanhol como língua estrangeira. Isto é: que língua é significada (e legitimada) nos instrumentos linguísticos produzidos para o seu ensino e quais são os efeitos glotopolíticos dessa filiação? Que padrão linguístico é projetado no processo de gramatização da língua, dialogando (ou não) com as justificativas dadas nos

\footnotetext{
${ }^{4}$ Essa matriz de sentidos está filiada, em parte, ao governo espanhol e a uma política linguística altamente centralista e normativa.

${ }^{5} \mathrm{O}$ movimento pan-hispânico designa uma comunidade transnacional baseada em vínculos idiomáticos, históricos, religiosos e sociais. Após a perda da maior parte das colônias americanas, no século XIX, a Espanha começou a repensar sua aproximação estratégica aos novos países, tentando reconstruir o imaginário da comunidade pan-hispânica: uma comunidade unida por uma língua comum (e compartida) que, trazendo confiança entre espanhóis e latino-americanos, permitiria ativar essa unidade (Arnoux, Del Valle, 2015; Sepúlveda, 2005). A projeção desse imaginário coexistiu sempre com grupos de resistência que viam nessa política a permanência do espírito expansionista espanhol e o produto de uma política neocolonial por meio da qual a Espanha assume uma missão tutelar como uma forma de manter e recuperar a sua preeminência política e econômica em América (Sepúlveda, 2005; Cifuentes, 2015). Em 2004 é formulada explicitamente a "nova política linguística pan-hispânica”, cujo objetivo é a gestão "democrática" da língua compartida. Ver também Del Valle (2005, 2007); Arnoux e Del Valle (2010); Fanjul (2011).

${ }^{6}$ Freda Indursky (2011, p. 73) trabalha com a noção forjada por Nora e afirma que os lugares de memória "se apresentam sob a forma de objetos, instrumentos, instituições, documentos, vale dizer, traços vivos constituídos no entrelaçamento do histórico, cultural e simbólico".
} 
documentos produzidos pelo Estado e nos próprios textos programáticos das gramáticas e manuais (introduções, prefácios, prólogos, etc)? Essas indagações permitem formular outra hipótese sobre uma regularidade que atravessa discursivamente o século XX: se as justificativas da política linguística do Estado e também em parte dos argumentos presentes nos paratextos dos instrumentos linguísticos trazem a um primeiro plano as relações com os países vizinhos e uma maior vinculação a eles, o processo de gramatização está atravessado por uma matriz de sentidos que valoriza uma tradição propagada a partir da Real Academia Espanhola e que se materializa de diversos modos. Podemos afirmar que as tensões e contradições que se produzem entre esses dois planos (os discursos do Estado - a política linguística explícita - e o processo de gramatização da língua) é também uma regularidade. Diante dessa observação, a pergunta lançada é pelos processos que ao longo da história produziram certas contradições e deram continuidade a elas. Nesse movimento por rastrear traços de uma memória discursiva, também nos perguntamos pelas transformações ocorridas ao longo do tempo.

(3) Finalmente, o terceiro núcleo - e as indagações a ele vinculadas - constitui a problemática mais ampla: por que o fato da língua espanhola ter estado na textualidade de decretos, leis e projetos de leis que, de forma descontínua, atravessam um século de história do Brasil (fazendo referência à importância do aprendizado da língua para o desenvolvimento das relações políticas, culturais e comerciais com os países vizinhos, ou argumentando em favor da integração), não foi suficiente para que a língua espanhola se enraizasse ou assentasse na escola? Por que a lei 11.161 , que reinsere ${ }^{7}$, de forma particular ${ }^{8}$, a língua espanhola no sistema educativo em 2005, sancionada num dos momentos mais sólidos, talvez, em termos de projeção de um imaginário latinoamericanista na América do Sul, que operaria em favor do ensino da língua ${ }^{9}$, teve uma

\footnotetext{
${ }^{7}$ Na instância nacional, o espanhol tinha entrado por lei no Colégio Pedro II em 1919 (decreto lei No 3674), ficando na grade curricular como disciplina optativa até 1925. Num segundo momento, é incorporado ao currículo do ensino médio com a lei Capanema (Lei $\mathrm{N}^{\circ} 4.244$ ), em 1942, âmbito de ensino do qual sai (ao igual que as outras línguas estrangeiras modernas) em 1961 por causa da promulgação, nesse ano, da Lei de Diretrizes e Bases. Em 1958, durante a presidência de Juscelino Kubitschek foi apresentado um projeto para equiparar o idioma espanhol ao inglês e francês nas diversas séries e em horas de aula (Projeto de Lei № 4.606).

${ }^{8}$ Essa lei estabelece a oferta obrigatória da língua espanhola nas escolas do ensino médio e a matrícula facultativa por parte dos alunos.

${ }^{9}$ Vale lembrar aqui que foi o ano do "não ao ALCA" (Área de livre comercio das Américas), um projeto que nasceu com o propósito de expandir o Tratado de Livre Comércio da América do Norte e que foi duramente criticado na IV reunião de presidentes das Américas que aconteceu em Mar del Plata (Argentina) em 2005. As críticas ao projeto, especialmente as de Hugo Chávez (em aqueles anos presidente da Venezuela), assinalavam que era uma ferramenta do imperialismo norte-americano para atuar sobre os países de Hispano-América. O "não" ao ALCA marcou o nascimento da "Alianza Bolivariana para los pueblos de Nuestra América (ALBA), que propunha uma nova forma de intercambio
} 
aplicação tão desigual nas diferentes regiões do Brasil e, em alguma delas, com um alto índice de insucesso? Que elementos da história do Brasil, da memória e representações sobre a língua nessa história, das relações internacionais e das relações políticas e culturais com os países vizinhos irrompem, tendo efeitos nesse insucesso e nesse não enraizamento da língua no sistema educativo brasileiro ${ }^{10}$ ? E, ao mesmo tempo, e a despeito disso, que aspectos nos permitem identificar certas transformações ao longo do tempo?

Vistas de uma perspectiva atual, a memória sobre o espanhol no arquivo jurídico e na legislação educativa e a relação que estabelecem com ela os instrumentos produzidos para o seu ensino continuam apresentando muitas incógnitas e, por isso, suscitando tantas perguntas. Partimos de uma cena contemporânea - e de três aspectos que a integram de forma entrelaçada ${ }^{11}$ - e adentramos no passado para poder compreendê-la de forma mais aprofundada.

Foi esse o ponto de partida, os aspectos que nos levaram à história, buscando por um lado compreender as indagações suscitadas de forma crítica e por outro rastrear os lugares de construção de uma memória. O resultado, depois de muitas redefinições das problemáticas que encadearam a reflexão e a pesquisa - devido a novos materiais e informações que foram surgindo ao longo do percurso, expandindo as inquietações iniciais -, é a tese que apresentamos nos quatro capítulos que concentram o trabalho realizado.

regional, posteriormente "Unión de Naciones Suramericanas (UNASUR, 2008) e mais tarde “Comunidad de Estados Latinoamericanos y Caribeños (CELAC, 2012). Ver também as palavras de Jorge Taiana (parlamentar argentino do Mercosul), em Los debates siguen vigentes e de Agustín Lewit (cientista político e jornalista argentino, pesquisador do Conicet e membro do Centro Estratégico Latinoamericano de Geopolítica) em Una década después, Disponível em: www.pagina12.com.ar/diario/elpais/1-2853642015-11-04.html. Um contexto que deveria ser favorável, mas que se mostrou (e mostra) tortuoso em afirmar essa língua enquanto componente curricular relevante para a formação dos alunos (Barros, Costa, Galvão, 2016) e para o desenvolvimento de uma cidadania regional. Andrea Pontes (2016) afirma que a simples imposição de uma lei não resolve sua aplicação. E Arnoux (2010) e Arnoux e Bein (2015) dão pistas do caminho a ser trilhado, somando à medida do Estado a necessidade de sensibilizar funcionários, docentes e a população no seu conjunto da importância do ensino da língua no processo estratégico de integração regional sul-americano.

10 Poderíamos incluir nessa reflexão as outras línguas estrangeiras modernas, no entanto, damos ao espanhol uma posição diferenciada nessa indagação, não só pelo lugar que ocupa como língua vizinha, próxima e regional, mas, especialmente, pelas justificativas específicas dadas pelo próprio Estado em diferentes momentos da história para a sua incorporação no sistema educativo.

${ }^{11}$ Apenas retomando a modo de síntese: (i) a presença de uma matriz de sentidos vinculada a uma política linguística centralista e normativa, (ii) as tensões entre os discursos do Estado e os textos programáticos dos instrumentos linguísticos e o modo como ocorre o processo de gramatização da língua e (iii) a série de inclusões e exclusões da língua e o seu não enraizamento no sistema educativo. 


\section{Recorte do objeto e justificativa}

Como dito acima, os dois momentos históricos selecionados que são do nosso ponto de vista chaves na história da incorporação do espanhol no ensino secundário no Brasil são os anos 1920 e a Era Vargas. A década de 1920 abriga três acontecimentos inaugurais: a implantação do espanhol no Colégio Pedro II em 1919, o primeiro concurso para ocupar o cargo e o surgimento da primeira gramática produzida no Brasil para o ensino da língua, a Gramática de língua espanhola para uso dos brasileiros, de Antenor Nascentes (1920). Na Era Vargas ocorrem a Exposição de Motivos da Reforma Capanema e a própria Reforma (1942) que determina a obrigatoriedade da língua espanhola nas escolas secundárias do Brasil e, como efeito, a aceleração da produção editorial para atender as demandas surgidas pela inclusão da língua na grade curricular. Do arquivo surgido nessa aceleração, selecionamos o Manual de Español (1945), de Idel Becker, e as reformulações realizadas pelo próprio autor (1947, após 1961), como estudo mais específico sobre a língua e seu ensino.

Cada um desses momentos históricos está marcado por conjunturas e acontecimentos específicos. Do emaranhado que os constitui, algumas diferenças nos parecem especialmente importantes: no primeiro, temos o primeiro gesto de institucionalização do espanhol no ensino secundário, em um Colégio de elite, na capital da República, e a produção da primeira gramática pelo primeiro professor concursado para o cargo, um autor negro em épocas de discursos sobre o branqueamento racial e de transformações significativas da que era por aqueles anos a capital da República, o Rio de Janeiro. Embora o Colégio funcionasse como paradigma e modelo, estamos diante de uma cena bastante pontual, inserida, por um lado, no contexto de um estado oligárquico que passava por um lento processo de dissolução da sociedade escravista e, por outro, em relações internacionais que nessas décadas privilegiavam o alinhamento do Brasil aos Estados Unidos, ficando as relações com os países vizinhos em um segundo plano.

No segundo momento se produz uma mudança significativa, tanto qualitativa quanto quantitativa: o espanhol passa a fazer parte do currículo do ensino médio como disciplina obrigatória. O Brasil se enuncia como nação e embora não exista uma generalização da educação pública, há uma tentativa de levar adiante um projeto de educação nacional, por meio de um processo de reestruturação que buscava torná-la mais democrática. Esse processo projetava outros imaginários e ampliava o campo de ação, expandindo o número de escolas. Também o número de alunos que teria a língua como 
disciplina obrigatória ampliou-se de forma considerada, fato que produziu uma clara aceleração da produção editorial. Assim, em poucos anos foram elaboradas várias gramáticas, compêndios e o Manual de Espanhol de Idel Becker (1945) sobre o qual focaremos a atenção. Esses acontecimentos se produzem durante o Estado Novo (19371945), anos em que, embora com restrições no terreno da cidadania civil e política, o Brasil se tornou mais moderno economicamente e menos excludente socialmente (Gomes, 2005).

Portanto, se a seleção dos dois momentos históricos e a pesquisa realizada sobre eles permitem estabelecer certa simetria na composição do trabalho (detectar e determinar aspectos que comporiam a rede complexa de condições de produção), os processos políticos e educativos, as respectivas sociedades, o modo como ocorre a inclusão da língua e a própria produção de instrumentos linguísticos em cada um deles (aspectos todos sobre os quais nos deteremos nos capítulos da tese), os configuram de forma assimétrica. Dois momentos diferentes em cujas temporalidades também se inscrevem diversos aspectos: a importância outorgada à educação pública, a atividade pedagógica, as concepções sobre o ensino de línguas estrangeiras, a produção de gramáticas e manuais, as representações dos adolescentes, o mercado editorial que precisa sempre posicionar seus livros, as posições políticas e o devir do país.

Além disso, as diferenças também se confirmam no terreno da historiografia. As diversas narrativas produzidas sobre cada período nos exigiram uma tomada de posição distinta diante dos fatos históricos e das diversas posições assumidas pelos historiadores. Se existe um maior consenso entre os estudiosos em que nos anos 1920 havia um Estado oligárquico cuja força estava assentada nas oligarquias regionais de cada um dos Estados da Federação, em que não existia um projeto nacional de educação e em que negros e mulatos eram perseguidos e estigmatizados produzindo uma sociedade partida (Luchessi, 2015), não podemos dizer o mesmo da Era Vargas. Desse período ressalta-se o caráter complexo e ambíguo da experiência vivida, o que também torna ambíguas as definições e representações produzidas. Marcos Napolitano (2017) assinala que entre os anos 1960 e 1980 se deu uma das maiores polêmicas da historiografia brasileira, em torno das interpretações acerca da Revolução de 1930 - que instaura o governo Vargas - e sobre seu impacto efetivo na história do Brasil, produzindo interpretações diversas. O historiador também afirma que se é verdade que o governo Vargas não ameaçou o poder das velhas elites regionais, também é fato que as submeteu a outro projeto político e econômico, pautado pela industrialização e o desenvolvimento nacional (ibid.). 
Na mesma direção, Angela de Castro Gomes $(2014,12)$ argumenta que "poucos períodos na história do Brasil produziram desdobramentos tão duradouros, importantes e ambivalentes como os oito anos que cobrem o chamado Estado Novo (1937-1945)”. A mesma autora (2005) afirma que Vargas foi amado e odiado; endeusado e vilipendiado; chamado de fascista, populista, autoritário e totalitário. Em seu trabalho, Gomes (2014) desmonta algumas dessas classificações, especialmente a de ter sido um governo populista e fascista/totalitário, assinalando que após a década de 1980 essas interpretações foram sendo gradativamente questionadas e abandonadas.

Assim, a proposta de mapearmos as condições de produção foi a mesma nos dois períodos, no entanto a realização do trabalho seguiu caminhos bem diferentes, já que em cada período eram outros os materiais, outros os autores - com suas respectivas trajetórias intelectuais -, outras as disputas e a importância dada à língua e outro o seu processo de gramatização. Em resumo, eram outras e diferentes as conjunturas sócio-históricas de produção. Para alcançar os objetivos da tese, em cada um dos momentos históricos tratados nos centramos nos aspectos que consideramos mais relevantes na configuração dessa rede de condições de produção. Haver tornado mais complexo o emaranhado que a integra adensou os objetos estudados, tornando as interpretações também mais complexas.

Os princípios metodológicos foram diversos. Por um lado, buscamos interpretar como se projeta a inclusão da língua no plano jurídico/legislativo - isso permite indagar a relação que o Estado estabelece com a língua e as tensões e jogos de forças advindas das relações internacionais. Por outro, tentamos compreender como se projeta nos instrumentos linguísticos estudados a imagem dos destinatários - alunos e docentes - e da língua gramatizada. Nesse último aspecto, focamos especialmente o processo por meio do qual a língua vai sendo vinculada a um determinado padrão linguístico, num movimento que ao recortar seleciona e exclui. Ao avançar no trabalho foram aparecendo marcas desse padrão linguístico, que, especialmente no primeiro período e em menor grau no segundo, estava alinhado a uma política linguística vinculada ao Estado espanhol, cujas referências - a Gramática da Real Academia Espanhola e a própria instituição reverberam nos instrumentos linguísticos estudados, funcionando como lugares de memória. Como efeito disso, buscamos compreender por que o processo de gramatização da língua estava marcado tão fortemente por esse dispositivo normativo. Surgiu assim uma indagação que ainda não tinha sido suficientemente explorada nos estudos produzidos até o momento sobre o processo de gramatização do espanhol no Brasil. 
Em síntese, a partir desses dois momentos históricos mapeamos permanências e rupturas para pensar sobre os modos como se produzem, reproduzem e transformam historicamente certos discursos sobre a língua espanhola no Brasil e sobre os diversos aspectos que vão determinando o modo de significá-la no seu processo de gramatização. A partir desses aspectos, abre-se espaço para diversas frentes de reflexão.

O trabalho colhe, organiza e relaciona acontecimentos, fatos e materialidades de diversas ordens, pondo em relevo os processos políticos em que acontecem e buscando aportar conhecimento sobre a história da língua espanhola no Brasil e sobre seu processo de gramatização.

\section{Articulação teórico-analítica}

A gramatização do espanhol como língua estrangeira no Brasil configura um espaço de reflexão glotopolítica. Essa reflexão se produz no cruzamento com a História das Ideias Linguísticas, um campo que remete ao conhecimento das línguas e da memória sobre elas e nos leva a refletir sobre o modo como os instrumentos linguísticos aparecem e se transformam, levando em consideração longos períodos históricos (Nunes, 2007). A pesquisa tem um caráter interpretativo, daí a estreita articulação com a Análise de Discurso materialista ${ }^{12}$. Assim, o trabalho propõe rastrear os modos como os instrumentos linguísticos projetam uma série de representações sobre a língua (variedade, norma, tensões na vinculação a um padrão linguístico etc.) e sobre o próprio processo de ensino-aprendizagem. Representações essas que ultrapassam amplamente o terreno do linguístico e que configuram a dimensão ideológica que atravessa o processo de gramatização em diferentes momentos históricos.

Nesse sentido, no dispositivo teórico-analítico proposto, discurso ${ }^{13}$ (especialmente a dimensão do político na estabilização de sentidos) e condições de produção são conceitos chaves. As permanências e transformações identificadas entre os dois períodos são interpretadas como indícios que nos permitem rastrear traços de

\footnotetext{
${ }^{12}$ Os trabalhos realizados a partir dessa articulação abordam os textos como discursos, isto é, como materialidades históricas e linguísticas que remetem às condições de produção (Pêcheux, 1990; Arnoux, 2006; Orlandi, 2007) por meio do reconhecimento, na materialidade linguístico-discursiva, de vestígios ou marcas dos processos históricos.

${ }^{13}$ Fanjul (2009, p. 190) faz uma síntese interessante para esta noção quando afirma que o discurso é "la dimensión donde lo histórico-social se encuentra con lo lingüístico y lo afecta, lo modifica”.
} 
uma memória discursiva ${ }^{14}$ sobre a língua espanhola. O campo de pesquisa que articula a perspectiva Glotopolítica ao dispositivo teórico analítico da Análise de discurso materialista e da História das Ideias Linguísticas tem demonstrado a força e importância de ler os instrumentos linguísticos como gestos de intervenção política da sociedade civil e do Estado no espaço público da linguagem: objetos discursivos e simbólicos cuja existência intervém de forma forte na construção de memórias e de imaginários.

Nesse sentido, esse trabalho tem relevância especialmente por inserir o estudo da produção e circulação de gramáticas e manuais de espanhol dentro de um campo de pesquisa mais amplo que investiga a gramatização das línguas nacionais como parte de uma tradição pedagógica que vem do Renascimento e que se multiplica no surgimento dos Estados nacionais na Europa e posteriormente em terras americanas. Um campo com tradição e uma importante produção científica sobre os processos pelos quais passaram as línguas nacionais, estudando o modo como os instrumentos linguísticos (especialmente gramáticas e dicionários) foram (e vão) produzindo um imaginário sobre a língua, e mais incipiente ao pensarmos no processo de produção de instrumentos linguísticos que produzem e projetam imagens de uma língua gramatizada como estrangeira.

Assim, o trabalho adentra num campo menos percorrido, com menos formulações e reflexões específicas, especialmente quando pensamos nos processos que vão produzindo a vinculação dessa língua - vizinha, próxima e regional - a um determinado padrão linguístico. Diversas pesquisas contribuem significativamente para a compreensão do funcionamento de uma memória sobre o espanhol no Brasil e sobre a gramatização da língua, focando de forma específica os livros didáticos como objeto de estudo, ou a institucionalização do ensino do espanhol no Brasil, ou ainda, analisando (por meio de diversos recortes temporais) o processo legislativo e jurídico que marca a entrada e saída do espanhol do sistema educativo brasileiro ${ }^{15}$. No entanto, reconhecemos

\footnotetext{
${ }^{14}$ Trabalhamos a noção de memória discursiva a partir da reflexão de Indursky (2011) quem afirma que "se há repetição é porque há retomada/regularização de sentidos que vão constituir uma memória que é social, mesmo que esta se apresente ao sujeito do discurso revestida da ordem do não sabido. São os discursos em circulação, urdidos em linguagem e tramados pelo tecido sócio-histórico, que são retomados, repetidos, regularizados" (ibid. p. 71). A autora acrescenta que a repetição "também pode levar a um deslizamento, a uma ressignificação, a uma quebra do regime de regularização dos sentidos" (ibid.). Dessa forma, a regularização dos sentidos decorrentes da sua repetição "não impedem a movência dos mesmos, ainda que em pequeno grau" (ibid. p. 79). E esse deslizamento "aponta para o modo como os lugares de memória funcionam discursivamente” (ibid.). A memória discursiva se refere a sentidos que se inscrevem em uma formação discursiva. Dessa forma, "ela diz respeito não a todos os sentidos, como é o caso do interdiscurso, mas aos sentidos autorizados pela Forma-Sujeito no âmbito de uma formação discursiva" (ibid. p. 86-87). E também aos sentidos que devem ser refutados.

${ }^{15}$ Podemos mencionar os trabalhos de Celada (2002), Picanço (2003), Rodrigues (2012), Vieira (2012), Cassiano (2013), Freitas et al. (2013), Guimarães (2014, 2018), Recuero (2017) e Danna (2019), dentre outros.
} 
que o aporte específico desta pesquisa se dá na construção da trama que liga processos políticos, sociais e educativos aos dois momentos iniciais de inclusão da língua no ensino secundário e das obras centrais selecionadas, detectando nelas as marcas que remitem às condições sócio-históricas de produção. Nesse sentido, as contribuições da tese não são devidas a abordar períodos ainda não estudados ou a apresentar obras desconhecidas, mas sim por examinar temporalidades e materiais já estudados apontando para questões diferentes, pouco discutidas pela literatura que se debruça sobre eles ${ }^{16}$. Sendo assim, este trabalho expande a rede de conhecimento já produzida e dá visibilidade à densidade que esses instrumentos discursivos têm como objetos de estudo.

Se as séries organizam parte do trabalho, outro elemento organizador são as inúmeras perguntas que o atravessam ${ }^{17}$. Além disso, a articulação teórico-metodológica inclui uma dupla dinâmica do processo de análise que combina uma dimensão sincrônica - que observa os processos em cada uma das duas conjunturas históricas selecionadas (com a riqueza de suas contradições e equivocidades) e permite indagar o interdiscurso de época (o horizonte de discursos possíveis) -, com outra de natureza diacrônica - que considera a produção de sentido a partir de uma perspectiva de longa duração histórica. Tal perspectiva permite identificar continuidades, rupturas, transformações e deslocamentos e tecer considerações sobre a memória discursiva. Esse percurso organizou o trabalho e nos levou a delinear um corpus complexo e dinâmico, não só na sua composição (materiais de arquivo específicos em cada um dos núcleos históricos), mas também, na possibilidade de colocá-lo em relação com outros materiais que o desenvolvimento da pesquisa foi solicitando.

\section{Estrutura da tese}

Além desta Introdução, na qual optamos por apresentar as problemáticas de forma mais geral, a tese possui quatro capítulos e considerações finais. Os dois primeiros focam os anos 1920 e os dois segundos abordam a Era Vargas. No capítulo 1,

\footnotetext{
${ }^{16}$ Por exemplo, os trabalhos de Guimarães (2014, 2018), Recuero (2017) e Danna (2019), já citados, abordam temporalidades e materiais próximos aos nossos, no entanto, a partir de diferentes pontos de vista, lugares de observação e perspectivas, produzem outra construção dos objetos estudados.

17 Arnoux (2008, p. 75) relembra que para Meyer (1987) "toda pregunta constituye un operador de conocimiento ya que muestra dónde está el problema, lo que permite la paráfrasis “la cuestión es saber...”. Já Sarlo (1994) entende que as perguntas permitem armar uma perspectiva para ver. A obra de Michel Meyer citada por Arnoux (2008) é De la problématologie, Bruxelas, Pierre Mardaga, 1987.
} 
trabalhamos sobre aspectos que integram a rede de condições de produção dos três acontecimentos inaugurais do primeiro período. Trabalhamos aqui a partir de três escalas diferentes de observação que organizam as seções do capítulo: as relações internacionais e a projeção de um Brasil fora da América Latina; o autor da obra, sua trajetória intelectual e a cidade e sociedade em que está inserido esse filólogo negro e, por último, a instância institucional, o Colégio Pedro II, tentando compreender aqui a inclusão do espanhol e a produção da Gramática num âmbito plurilingue de ensino. No capítulo 2, abordamos a formação de Nascentes em meio aos debates e disputas linguísticas de época - as décadas iniciais do século XX - e rastreamos, por meio da análise de parte da sua vasta obra sobre o português do/no Brasil, as marcas que funcionam como indícios de suas concepções linguísticas. Na segunda parte do capítulo buscamos compreender as projeções dessas concepções no processo de produção da Gramática de espanhol, e as particularidades (e desafios) desse processo de elaboração. No capítulo 3, apresentamos os discursos do Estado varguista e a projeção da inclusão da língua dentro de um projeto político-educativo. Para tanto, analisamos a Exposição de Motivos da Reforma Capanema e a própria Reforma que promulga a inclusão da língua como disciplina obrigatória, ambas de abril de 1942 e o Programa de Espanhol expedido pela Portaria $\mathrm{N}^{\circ} 127$, de fevereiro de 1943, assinada pelo ministro de Educação e Saúde Gustavo Capanema. Além desses discursos governamentais, abordamos a aceleração da produção editorial, da qual estudamos algumas regularidades. Para finalizar o capítulo, trazemos aspectos da biografia de Idel Becker e rastreamos nos paratextos de três obras de fôlego, escritas entre 1943 e 1945, as suas ideias sobre a língua espanhola, sobre o modo como compreendia a relação entre essa e o português e a projeção dos destinatários - alunos e professores. Finalmente, no capítulo 4, analisamos o Manual de espanhol de 1945 e as reformulações que o próprio autor faz da obra (1947 e posterior a 1961).

Nas considerações finais, num primeiro momento, realizamos uma releitura da textualização desenvolvida retomando determinados aspectos para, num segundo momento, apresentar mais um documento do arquivo legislativo, cuja abordagem nos permite retornar à cena disparadora da pesquisa e propor uma interpretação sobre a construção de uma memória discursiva do espanhol no âmbito escolar brasileiro, atravessada por históricas disputas e sentidos antagônicos. 


\section{CAPÍTULO 1}

A inclusão da língua no Colégio Pedro II e a produção da

Gramática de Nascentes 
No Brasil, os anos vinte do século passado estão marcados por uma atmosfera intelectual, artística e política de muita efervescência ${ }^{18}$ : debates e disputas em torno da língua nacional ainda sem nome definido ${ }^{19}$, das relações internacionais (devedoras do período anterior no qual o Barão do Rio Branco tinha dirigido o Itamaraty entre 1902 e1912) e vivendo os efeitos da escravidão recentemente abolida ${ }^{20}$. Zonas de confronto de uma república em formação que contava com tão só trinta anos.

Esse momento faz parte do regime político que se conhece como Primeira República ou República Velha, entre 1889 e 1930²1. Um período histórico com uma sociedade particular que constitui o marco no qual acontece o primeiro gesto que inclui a língua espanhola no ensino secundário, o primeiro concurso público para preencher a vaga de professor de espanhol no Colégio Pedro II e a produção da primeira Gramática para o ensino daquela língua. Três acontecimentos inaugurais estreitamente vinculados entre si que abordaremos neste capítulo e no próximo a partir de recortes diversos.

Menos que abordar exaustivamente a história do Brasil nesses anos, iluminamos aqui algumas questões relevantes do período que propiciam uma melhor compreensão da sociedade, da cidade e do espaço institucional nos quais acontece a inclusão do espanhol e as condições sócio-históricas de produção da Gramática de Nascentes: um estado oligárquico, uma sociedade que propunha o branqueamento racial, uma educação elitista, representações de um grupo importante da diplomacia brasileira que projetavam

\footnotetext{
${ }^{18}$ Entre outros acontecimentos, essa efervescência acaba desencadeando em São Paulo a "Semana de Arte Moderna", em fevereiro de 1922. É um momento transgressor no uso da linguagem e vários manifestos e revistas expressam o desejo de inovar nas linguagens artísticas e mostram a preocupação por entender a identidade brasileira ou as múltiplas identidades.

${ }^{19}$ Mariani e Medeiros (2010, p. 15) afirmam que "embora a discussão sobre o nome da língua do Brasil tenha ocorrido no século XIX e nas primeiras décadas do século XX, é somente nos anos 1940 que se tem a designação - no campo jurídico - da língua oficial como língua portuguesa".

${ }^{20}$ A Lei Áurea, uma lei imperial de 13 de maio de 1888, dera fim "à instituição que por mais de três séculos marcou de maneira profunda a vida cotidiana do Brasil” (Fraga, 2018, p. 351). A abolição não trouxe uma proposta do Estado para esse negro liberto. Como afirma Lucchesi (2015, p. 115) após a Lei, "a população de ex-escravos [foi] entregue à própria sorte”, já que esse acontecimento "não foi acompanhado de qualquer política governamental de reinserção desse contingente no sistema produtivo do país". Dessa forma, a abolição só reafirmou a situação de uma "sociedade partida" (ibid.), contribuindo para a marginalização do afro-brasileiro (Ventura, 2000).

${ }^{21}$ 1889: data que marca a caída do Império e a mudança do regime político; 1930: golpe de estado pelo qual Getulio Vargas chega ao poder e inicia um novo período político. Um período significativo que compreende a transição de um modo de produção escravista para o modo de produção capitalista no Brasil (Benchimol, 1992).
} 
uma República "fora” da América Latina e a capital da República em intensa transformação, palco dos acontecimentos estudados: o Rio de Janeiro da "belle époque"22.

Com a proclamação da República (1889), o Brasil passava a adotar o mesmo sistema político dos demais países latino-americanos - República Federativa -, “deixando de ser a flor exótica representada por uma monarquia entre repúblicas” (Fausto e Devoto, 2004, p. 147). A despeito da mudança ocorrida com o advento do novo sistema, essa marca diferenciadora (ser uma monarquia entre repúblicas), que afastara o Brasil do resto dos países cujas revoluções tinham provocado a independência da antiga metrópole (a Espanha) e tinham dado lugar à criação dos novos estados, teria efeitos bastante duradouros ao longo de todo o século $\mathrm{XX}$, obstaculizando uma aproximação real com as jovens repúblicas hispano-americanas.

Além disso, a consolidação da República no Brasil se dá sobre uma lenta dissolução da sociedade escravista. Vale lembrar que foi o último país livre independente com escravos e o único Estado na América Latina em que uma monarquia legítima construíra um Estado Nacional. Esse aspecto é significativo e reforça a distância que se estabelece naqueles anos entre o Brasil e os países hispânicos da América Latina ${ }^{23}$.

Com a transformação política, e mesmo antes dela, as elites que estavam no poder apostaram numa exclusão (ou inclusão seletiva) do conjunto da população brasileira. A partir de 1891 e especificamente por meio do art. 70 da Constituição, a República proíbe o voto analfabeto (Fausto et al., [1997] 2006, p. 284). Ao longo do século XIX votava cerca do $10 \%$ da população do país. Após a Lei Saraiva (1881), ainda no período imperial, o corpo político é reduzido a $0,8 \%$ da população: a lei

\footnotetext{
${ }^{22}$ Vale lembrar que entre 1902 e 1906 o Rio passa por uma importante reforma urbanística levada a cabo pelo então prefeito Pereira Passos, que faz da velha capital de ares coloniais uma nova cidade, a "moderna" capital da República. Inspirado nas reformas urbanas de Paris, o Rio se "civilizava" - expressão utilizada pelos contemporâneos nos jornais - e com isso, afastava os extratos mais pobres da população do centro, impulsionando as primeiras ocupações dos morros e dando origem às primeiras favelas. Com a inauguração da Avenida Central saiu vitorioso o combate contra a velha cidade e suas formas de sociabilidade. Porém, restara ali a memória de uma cidade plebéia que o romantismo literário construíra: "o que a reforma urbana aplastava, a memória revivia” (Carvalho, 2019, p. 28). A reforma embelezadora teve ainda uma face sanitarista, com a atuação do médico Oswaldo Cruz e a campanha de vacinação obrigatória, cuja contra-face ficaria conhecida como a "Revolta da Vacina". Na década de 1920, o prefeito Carlos Sampaio dá continuidades às reformas, demolindo o Morro do Castelo e criando uma imensa esplanada no centro, ocupada nos anos seguintes, já no contexto do Governo Vargas, pelos novos Ministérios do Estado Novo (Sevcenko, 1993; Carvalho, 1987; Needell, 1993).

${ }^{23}$ Outro aspecto estabelecera anteriormente essa distância: o fato da Independência do Brasil (1822) não ter acontecido pela via de um corte revolucionário com a metrópole (como tinham feito as jovens nações que se independizaram da Espanha), mas por um processo que resultara de algumas mudanças e muitas continuidades com relação ao período colonial (Fausto, 2015). Uma independência política proclamada por um príncipe português.
} 
dobrava a renda exigida (com comprovante) para poder votar e já era exigida a assinatura em uma sociedade em que o analfabetismo era desolador (ibid.). Na mesma direção, Viscardi (2001, p. 75) faz referência à exclusão do analfabeto do sistema político, assinalando que a primeira medida implementada ao se estabelecer a República “foi garantir a exclusão da participação dos setores populares, pelo estabelecimento normativo do 'voto alfabetizado' e pela criação de meios que possibilitassem a fraude eleitoral”. Dessa forma, a “vontade nacional” era resolvida por uma insignificante minoria. A estabilidade do regime republicano baseou-se no fato de as oligarquias regionais controlarem a política e a economia, sendo a consolidação dessas oligarquias regionais ligadas às atividades agro-exportadoras a base do Estado oligárquico recém constituído (ibid.). Sendo assim, os centros econômicos do país ditavam a ocupação da presidência, acordo que mantinha o controle político do Brasil nas mãos daqueles que controlavam a economia. Viscardi também chama a atenção para a ausência de grupos políticos nacionais duráveis e afirma que o destino da Federação "era decidido por um número restrito de atores, oriundos de um número restrito de estados-membros, eleitos por um corpo restrito de eleitores” (ibid. p. 79).

Após a proclamação da República, diversas ideias, propostas e sentimentos que tinham contribuído para a erosão do edifício imperial entravam em confronto ao pensar-se a República a ser implantada, como afirma Mattos (1989). Segundo esse autor, tais confrontos tinham a ver com os diferentes projetos a respeito das relações sociais na nova nação republicana. As discordâncias estavam nos fundamentos da nacionalidade, na amplitude da cidadania, no papel reservado à educação, entre muitas outras questões (ibid.) ${ }^{24}$.

Nesse contexto, a pouca disseminação da escola primária, secundária e superior impossibilitava o alargamento na composição das elites, favorecendo que as oligarquias fossem pouco combatidas e, ao mesmo tempo, assentassem seu poder sobre esse analfabetismo. A passagem do Império para a República está assim marcada pelas precárias condições do sistema escolar.

O sistema político da Primeira República localiza o poder nos Estados que podiam contrair empréstimos no exterior, decretar impostos de exportação, ter suas próprias constituições e corpos militares, bem como códigos eleitorais e judiciários (Souza, 1968, p. 162-166). Essa conjuntura tem efeitos sobre o sistema escolar, já que são os Estados que procedem a implantar ou reorganizar a administração escolar,

\footnotetext{
${ }^{24}$ Viscardi (apud Bolognesi, 2018) afirma que vão surgindo visões de mundo diferentes e até antagônicas e que é isso o que mais adiante vai conduzir à Revolução de 1930.
} 
criando-se uma espécie de "dualismo” do sistema: a União se encarregava das escolas secundárias e superiores (escolas da "elite”, entre as quais se enquadra o Colégio Pedro II), enquanto os Estados cuidavam da educação primária e técnico-profissional (as escolas do "povo”) (Fausto et al., 2006, p. 289). Não existia ainda um sistema escolar nacional ou uma política nacional de educação (ibid.).

É justamente nesse contexto político, social e educativo que o espanhol é incorporado no Colégio Pedro II, no Rio de Janeiro, e é publicada a Gramática da Língua espanhola para uso dos brasileiros (1920). Sendo a primeira gramática de espanhol produzida no Brasil, pode ser considerada um discurso inaugural já que dá início ao processo de gramatização brasileiro da língua. Seu autor, Antenor Nascentes, fora o primeiro colocado no concurso público que, em 1919, selecionou o primeiro professor catedrático para a cadeira de espanhol, criada no Colégio Pedro II pela Lei n. 3.674, de 7 de Janeiro de 1919. Seu programa tinha sido aprovado - segundo publicação do Diário Oficial da União - em 5 de abril do mesmo ano (Guimarães, 2014). A produção da Gramática deve ser entendida à luz desse acontecimento, também ele inaugural: a entrada da disciplina de espanhol no ensino secundário, num colégio onde desde a sua criação, em $1837^{25}$ se formava a elite dirigente e cujos programas serviam de paradigma para todo o universo educacional brasileiro ${ }^{26}$. Uma obra claramente pedagógica que buscava atender as demandas geradas por esse gesto específico de política linguística do Estado brasileiro.

Assim, tentando compreender a incorporação da língua ao Colégio e a produção da Gramática como dois nós numa rede ampla de entrelaçamentos que constituem as condições sócio-históricas de produção, neste capítulo abordaremos alguns aspectos dessa série de acontecimentos inaugurais. A pesquisa busca alargar e dar visibilidade a um tecido complexo de determinações históricas que têm efeitos diversos nos acontecimentos abordados, ampliando o campo de interpretações em outras direções. Essa trama inclui diversas instâncias, dentre elas, a institucional: a tradição de um

\footnotetext{
${ }^{25}$ As origens do Colégio datam de 1739 quando foi fundado o Colégio dos Órfãos de São Pedro, origem do Seminário de São Joaquim que por decreto de 1837 se transformou no Colégio Pedro II (no dia em que Dom Pedro completava doze anos). Bernardo Pereira de Vasconcelos, ministro do Império, foi o idealizador da fundação dessa instituição federal de ensino que foi (e é) um marco na educação brasileira. Nele se educaram personalidades ilustres de diversas áreas, das letras à política (Doria, 1997). A origem no Colégio dos Órfãos fez com que ao longo da sua história o Colégio mantivesse um número significativo de bolsas de estudo, das quais Nascentes foi um dos seus beneficiários.

${ }^{26}$ A falta de uma legislação educativa nacional deu esse lugar de "escola modelo" ao Colégio Pedro II. Segundo Westphalen (1998, p. vii), os programas desenvolvidos para o Colégio Pedro II representavam, em certa medida, os programas do ensino secundário oficial, tendo-se em vista que o colégio era considerado modelo para os outros estabelecimentos.
} 
colégio de elite com ensino plurilíngue, no qual os alunos tinham aulas de inglês, francês, alemão, grego e latim. Quando se incorpora o espanhol já existiam instrumentos linguísticos - livros e programas de ensino - que haviam sido produzidos para as outras línguas. Também a tradição no ensino de línguas estrangeiras, na qual o contraste e a comparação configuravam, naquela época, uma prática dominante. Por outro lado, pensamos também nas relações internacionais e nas representações sobre os países da América Latina - e do imaginário criado em torno deles -, cuja língua nacional era aquela que estava sendo incorporada. Além das instâncias mencionadas, refletimos sobre os efeitos de Nascentes ser um autor negro em um país com a escravidão recentemente abolida e em uma sociedade específica com discursos médicos e biológicos sobre o branqueamento racial. Como é construída a voz do autor a partir desse lugar subalterno e de que modo a produção da Gramática está afetada pelo lugar ocupado por esse sujeito. Finalmente, no próximo capítulo, trabalharemos sobre os efeitos que as disputas e os debates linguísticos de época têm, não só na formação de Nascentes como lexicógrafo, filólogo e gramático, mas também na configuração de uma norma na Gramática de espanhol.

Assim, de modo geral, busca-se interpretar a obra e o recorte que nela se faz da língua (com a consequente legitimação de uma norma) à luz das instâncias elencadas, isto é, das várias redes de determinações. Tornar mais complexa essa estrutura não só nos faz compreender de modo mais completo a obra - adensando as camadas de interpretações possíveis e ampliando assim as já realizadas -, mas também nos permite iluminar diversos aspectos das condições sócio-políticas de produção, dentre eles, a importância que as relações internacionais do Brasil com os países da América Latina e com os Estados Unidos têm para compreender o processo por meio do qual se dá a inserção do espanhol no sistema educativo.

Na organização do capítulo propomos três seções, que no modo de abordar as problemáticas, remetem a três escalas distintas de reflexão e abordam diferentes redes de determinações: as relações internacionais, o indivíduo - como autor da obra - e a sociedade na qual se insere, e por último, o institucional. $\mathrm{Na}$ primeira seção, abordaremos a entrada do espanhol no sistema educativo brasileiro, buscando interpretar os acontecimentos que levaram à inclusão da língua e, fundamentalmente, o processo como aconteceu essa inclusão (e posterior exclusão), à luz das relações internacionais que o Brasil mantinha com os países hispano-americanos e com os Estados Unidos, pensando os movimentos de inclusão/exclusão como indício das 
condições de produção. Na segunda seção abordaremos aspectos da biografia e a trajetória intelectual de Nascentes, o primeiro professor concursado para a cadeira de espanhol e autor dessa primeira Gramática. Levando em consideração que a Gramática é produzida por um sujeito constituído ideologicamente em condições históricas específicas e que autor e obra são, dialeticamente, produto e produtores da história nesse contexto específico de produção, traçamos percursos que buscam interpretar a trajetória do autor, em relação estreita com uma época, com uma sociedade e com a atmosfera intelectual e política que a conformava ${ }^{27}$. Finalmente, busca-se refletir sobre os efeitos do institucional, da tradição plurilíngue já existente no Colégio, analisando alguns aspectos da Gramática à luz de uma série montada com instrumentos linguísticos para o ensino das outras línguas, para pensar regularidades e diferenças, isto é, as aproximações e afastamentos da obra de Nascentes com relação a essas outras obras, cuja circulação e uso eram anteriores à Gramática de espanhol.

Assim, propomos pensar a Gramática a partir do entrecruzamento de escalas diferentes de análise. Segundo a ideia chave ligada à variação de escala - os "jogos de escala” na expressão do historiador francês Jaques Revel (1998) -, não são os mesmos encadeamentos que são visíveis quando se muda de escala, mas sim conexões diferentes que teriam passado despercebidas. "Variar a objetiva não significa apenas aumentar (ou diminuir) o tamanho do objeto no visor, significa modificar sua trama e sua forma”, diz Revel (ibid., p. 20). Ou seja, nessas três perspectivas propostas, não se trataria apenas de ver o objeto de perto ou vê-lo de longe ou, ainda, de vê-lo de diferentes ângulos, mas de ver diferente em cada uma das instâncias propostas, podendo ver em cada nova escala o que não se viu nas outras.

\section{Relações internacionais: Brasil, Estados Unidos e “a outra América Latina”}

A Gramática, um dos objetos centrais do nosso estudo, é produzida para atender as necessidades que surgem da entrada do espanhol no Colégio Pedro II. Diante desse gesto que compreendemos como parte da política linguística do Estado, cabe perguntar: por que se incorpora o espanhol nessa data em um Colégio frequentado pela elite

\footnotetext{
${ }^{27}$ A perspectiva adotada propõe analisar a Gramática como discurso, isto é, entendendo-a "como um objeto teórico, integralmente linguístico e integralmente histórico, [...] que permite estudar a relação entre a língua (o sistema de signos linguísticos) e a ideologia (como determinação histórica do sentido pelas relações de força que se confrontam numa dada formação social” (Zoppi-Fontana, 1997, p. 34).
} 
carioca? O que acontecia no Brasil e nas relações com outros países da região que, em certa medida, propiciou a incorporação do espanhol como disciplina optativa, ampliando assim o currículo plurilíngue já existente ${ }^{28}$ Que aspectos da política externa do Brasil guardam relação com esse acontecimento?

As palavras do autor na Introdução da Gramática trazem pistas para iluminarmos as indagações formuladas. Nascentes ressalta como dado conjuntural para a criação da cadeira de espanhol o fato de

o Brasil [estar] cercado de países onde se fala [essa língua] e com os quais se acha em relações constantes, de ordem política, comercial, etc. $\left(1934^{29}\right.$, p. 3).

A situação geográfica e as relações constantes com os países vizinhos parecem fundamentais nas palavras do autor. Se o significante “cercado" parece expressar essa proximidade e o fato de o Brasil estar rodeado, circundado por esses países com os quais se relacionava, o efeito polissêmico permitiria ampliar a interpretação e imprimir ao significante os sentidos de "ameaça” que também convoca. Nessa leitura, "estar cercado" se apresentaria como a ponta de um iceberg, condensando tensões dessa conjuntura da qual ficariam ocultos os fantasmas da guerra $^{30}$ e, especialmente, nesse contexto específico, as tensões com a América hispânica, a “outra América Latina”, em palavras de Prado (2001). Uma relação tensa à qual daremos visibilidade ainda neste capítulo.

No entanto, são as constantes relações políticas e comerciais com os países da região as que levam o autor a afirmar que

é de grande vantagem para os brasileiros o conhecimento não perfunctório
daquella lingua, assim como o da língua portuguesa o é para os naturais de
outros países da América do Sul (Nascentes, 1934, p. 3, itálico nosso). Em 1920, Nascentes já tinha a dimensão da importância do aprendizado mutuo dessas duas línguas da região (“para os brasileiros o conhecimento não perfunctório” do espanhol, e o aprendizado da língua portuguesa "para os naturais de outros países da América do Sul”) - antecipando decisões glotopolíticas que apareceriam só no final do

\footnotetext{
${ }^{28}$ A língua espanhola já fazia parte do Ensino Militar Superior desde 1905 e dos Estudos Comerciais desde 1907 (Guimarães, 2014).

29 Realizamos as análises a partir da terceira edição da obra, de 1934. Quando necessário, faremos algumas observações sobre uma primeira edição encaminhada pelo Prof. Adrián Fanjul (em PDF), a quem agradecemos pelo achado no momento do exame de qualificação. Tomamos essa decisão após cotejar ambas as gramáticas e identificar as poucas reformulações presentes na versão que aqui adotamos, dentre elas, certas modificações na ortografia.

$30 \mathrm{O}$ mundo vivia os temores pela primeira grande guerra mundial e de forma mais delimitada geograficamente, viviam-se ainda os temores pelas constantes guerras decorrentes de problemas da demarcação das fronteiras.
} 
século XX com o Mercosul $^{31}$. Segundo Nascentes, foi a compreensão dessa vantagem a que levou o governo do Uruguai a criar uma cadeira de português:

E tanto assim o compreendeu o governo do Uruguai que criou uma cadeira de português, em reciprocidade da qual a lei n. 3.674 de 7 de Janeiro de 1919 criou uma cadeira de espanhol no Collégio Pedro II” (ibid.) ${ }^{32}$.

A afirmação da necessidade de um conhecimento "não perfunctório” da língua, isto é, não superficial, realizado em profundidade, exigia (e justificava) a necessidade de um estudo formal que aprofundasse o conhecimento que se tem pelo simples contato e circulação.

Assim, os argumentos do autor não só parecem apontar para um horizonte de países com os quais o Brasil tinha “relações constantes” (os países da “América do Sul”), mas também para a importância da institucionalização da língua para que o aprendizado fosse possível. Naqueles anos, o âmbito para o estudo de línguas estrangeiras (clássicas e modernas) era a escola, e a entrada do espanhol na grade curricular ampliava o ensino plurilíngue já existente (Rodrigues, 2012). Uma tradição de formação que já contava com programas de estudo, manuais e gramáticas para o ensino das outras línguas.

Vale lembrar aqui que a escola era para poucos - tratava-se, nas palavras de Fausto já citadas, das “escolas da elite” (especialmente no ensino médio e superior, os níveis atendidos pelo Colégio Pedro II) - e que a obra foi produzida especificamente para essa situação de ensino formal que, como abordaremos na próxima seção, o autor conhecera como aluno, bem antes de assumir a cadeira de espanhol. Para essa elite assumia-se um ensino plurilíngue que se deixa entrever em diversos momentos na própria Gramática. Por exemplo, nas explicações do capítulo 1 dedicado à pronúncia das letras o autor exemplifica com formas das línguas que faziam parte do universo escolar dos alunos:

O ch se pronuncia th, como o ch inglez de child ou $c$ italiano antes de e ou de i” (p. 8), “O y soa como $i$. Diante de vogal seu som lembra imperfeitamente o do $j$ português, Toro y Gómez chega a representar por $d j$, som do $j$ inglês em

\footnotetext{
${ }^{31}$ Em 13 de dezembro de 1991, os Ministros de Educação da Argentina, Brasil, Paraguai e Uruguai, levando em consideração os objetivos do Tratado de Assunção assinado em 26 de março de 1991, declaram, no art. 4 do Protocolo de Intenções “[...] el interés de difundir el aprendizaje de los idiomas oficiales del MERCOSUR - español y portugués - a través de los Sistemas Educativos; formales, no formales e informales" (Sokolowicz, 2014, p. 44).

${ }^{32}$ Essa lei foi uma lei orçamentária dos Estados Unidos do Brasil e nela se destinava a verba para que funcionasse no Colégio Pedro II a cadeira de espanhol. Retomaremos esse dado ao longo da seção, já que parece ser uma pista importante para entendermos o que interpretamos como uma "tênue" entrada da língua no ensino básico, ou como afirmam Quintela e Da Costa (2013, p. 439): "um tímido projeto de incorporação do espanhol ao Ensino Médio do Brasil”. Mas, quais seriam alguns possíveis motivos para essa tímida incorporação?
} 
Jhon ou do $g$ italiano antes de $e$ ou de $i$. O som verdadeiro, neste caso é o do iott alemão em jemand (Nascentes, 1934, p. 10).

Outros recortes, ao longo da obra, permitem acompanhar como o autor se vale desse universo plurilíngue conhecido pelos alunos:

A forma neutra do pronome de $3^{\text {a }}$ pessoa singular ello, que não existe em português, pode ser comparada ao il francês de certas frases como Il estvrai, ao it inglês e ao es alemão (ibid., p. 40).

Há ainda em espanhol o pronome Usted, que embora etimológicamente corresponda ao português você, não tem igual emprego. Você é o tratamento que se dá às pessoas com quem temos familiaridade; usted embora seja também familiar, é um tratamento cortês, como o vous francês, o you inglês e o Sie alemão, e neste caso corresponde a o Sr., a Sra. Tem o plural Ustedes (ibid., p. 41).

Hacia significa para (direç̧ão); compare-se com o francês vers: voy hacia Madrid (ibid., p. 72).

O advérbio também nas frases negativas traduz-se por tampoco (cfr o francês aussi, non plus) (p.103).

E ao tratar da conjunção adversativa "sino", comenta:

Há ainda sino cujo emprego se parece com o da conjunção alemã sonders e traz certa dificuldade ao brasileiro (p. 104).

Retomando aqui os argumentos de Nascentes para a inclusão da língua como disciplina optativa - a reciprocidade com uma medida parecida do governo uruguaio que tinha criado uma cadeira de português - cabe perguntar: como se deu essa reciprocidade anunciada por Nascentes e em que medida compreender essa “cordialidade diplomática” e esse ato de correspondência no que se refere ao ensino da língua pode somar elementos para a reflexão aqui proposta?

De fato, como afirma o autor, o governo uruguaio parecia ter compreendido a importância de um aprendizado não superficial do português. Essa compreensão levou, em 1917, a uma resolução que propunha a incorporação do português no terceiro ano da Escola Militar, destacando a importância do conhecimento da língua por parte dos oficiais (e dos futuros oficiais do Exército) que operavam nos departamentos limítrofes, não só pelo contato existente entre os exércitos nessas regiões de fronteira, mas também pelo contato existente com a população brasileira ${ }^{33}$.

Menos de dois meses depois de tomada essa medida, o Uruguai solicitava ao Brasil um ato de reciprocidade, em nota endereçada em 5 de dezembro de 1917 ao

\footnotetext{
${ }^{33}$ Remetemos o leitor que quiser aprofundar sobre a série de decretos, resoluções, avisos, cartas e pedidos diversos aos trabalhos de Recuero (2017) e aos de Anselmo Guimarães (2014, 2018). Trabalhos cujas pesquisas de arquivo auxiliaram o desenvolvimento do nosso.
} 
Ministro das Relações Exteriores do Brasil, Dr. Nilo Peçanha. Junto à nota foi encaminhada uma tradução do decreto e se insistia em que os mesmos motivos que tinham conduzido o Uruguai a ensinar o português (a necessidade de facilitar as relações oficiais) deviam levar o Brasil a adotar uma medida recíproca. No começo do ano seguinte (fevereiro de 1918), Nilo Peçanha destacava que além das vantagens de ordem social, do ponto de vista militar essa medida de reciprocidade se impunha, já que “muito [lucrariam] em efficiencia os nossos officiaes, se tiverem um conhecimento, tão perfeito quanto possível, do idioma de todos nossos vizinhos” (Brasil, 1920, p. 185, apud. Guimarães, 2014, p. 33).

Uma série de notas levou à incorporação do espanhol nos Colégios Militares. A partir de setembro de 1917, outra sequência de escritos encaminhados pelo Ministério de Relações exteriores ao Ministério de Justiça e Negócios Interiores (endereçadas ao Ministro Carlos Maximiliano), sugere corresponder ao gesto do Uruguai com a criação, no Colégio Pedro II, de uma cadeira de língua espanhola, não só como uma forma de homenagem que o Brasil prestaria àquela nação e às demais que falam essa língua, mas também porque facilitaria o intercâmbio intelectual com os países hispano-americanos (Recuero, 2017).

Em outubro de 1917, o Ministro solicitava à Congregação do Colégio Pedro II a criação da cadeira de língua espanhola e literatura hispano-americana (ibid.), medida que só seria implementada dois anos depois. Parece interessante analisar a materialidade desse decreto de política linguística do Estado com relação às línguas estrangeiras, neste caso específico, o espanhol. Diferentemente do que vai acontecer em toda a política linguística posterior, que atravessa o século XX com decretos, leis e projetos de leis nos quais a incorporação do espanhol é defendida e justificada nos próprios textos jurídico/legislativos pelas relações que o Brasil mantém com os países vizinhos, neste decreto específico e após anos de resoluções e pedidos, de notas e argumentos em prol da reciprocidade e da importância do estudo de ambas as línguas, a incorporação do espanhol no Colégio é anunciada por meio do aumento da verba repassada à instituição "para atender as despezas com a creação da cadeira de hespanhol em aquelle collegio, em reciprocidade do acto idêntico da República do Uruguai” (Brasil, Lei 3.674 de 7 de janeiro de 1919, apud. Recuero, 2017, p. 125).

Diante da modalidade do processo que levou à inclusão da língua nos perguntamos se a incorporação do espanhol foi apenas um ato diplomático de reciprocidade. Embora o Ministro das Relações exteriores tenha feito menção à homenagem que com a incorporação da língua o Brasil prestaria não só ao Uruguai, mas 
às demais nações hispano-americanas, facilitando o intercâmbio intelectual com esses países, ainda cabe indagar: qual era o interesse do Brasil na incorporação da língua no Colégio Pedro II? E em que medida pensar sobre essas questões pode ajudar a compreender esse "tímido projeto de incorporação do espanhol ao ensino médio do Brasil”, como observam Quintela e Da Costa (2013) e a curta permanência da língua nesse âmbito escolar. Vale assinalar que ficou no currículo do Colégio Pedro II como disciplina optativa até a reforma João Luiz Alves/Rocha Vaz, de 1925, que a retirou do currículo. A próxima entrada no sistema educativo aconteceria em 1942, na Era Vargas, inclusão mais potente (já que a língua é incorporada no currículo nacional do ensino médio) que estudaremos nos capítulos 3 e 4.

Se a reciprocidade com a política linguística uruguaia tinha sido um dos argumentos para a incorporação da língua no Colégio, a não reciprocidade dos países hispano-americanos na incorporação do português foi um dos argumentos dados pelo Estado para a não permanência da língua, como registra o próprio Nascentes na Introdução do Dicionário Etimológico, de 1931. Diz o autor ao se referir à época em que ministrara a disciplina Língua Espanhola no Colégio Pedro II:

\footnotetext{
A cadeira era facultativa, o que me trouxe os maiores dissabores.

Os que lidam no magistério sabem como são estudadas as cadeiras obrigatórias e bem podem imaginar como o seria uma facultativa. Quando se planejou uma reforma do ensino em 1925, fui ao ministro do interior de então, o Dr. João Luiz Alves, e lhe expus a minha situação, pedindo a obrigatoriedade da cadeira.

O ministro me objetou a sobrecarga do ensino secundário, a falta de reciprocidade por parte dos países hispano-americanos e não me atendeu (Nascentes, 1931, p. X, grifos nossos).
}

Diante do que se apresenta como uma incorporação da língua (facultativa) que buscava dar resposta diplomática ao gesto do Uruguai, é interessante observar os movimentos de Nascentes em busca da institucionalização "plena” da língua (a obrigatoriedade) que a igualaria às outras (francês, inglês e alemão, além do grego e o latim).

A argumentação da reciprocidade na incorporação do espanhol no Colégio Pedro II e da não reciprocidade para tirar a língua da grade (mesmo que optativa), a dinâmica do processo da inclusão e a menção feita pelo autor na Introdução da Gramática à importância das “relações constantes” que o Brasil tinha com os países da América do Sul para o ensino da língua, nos leva a abrir a reflexão para essas relações, e mais do que isso, para as representações e os discursos sobre as relações internacionais que perpassam o imaginário sócio-político daqueles anos. Qual era esse imaginário e quais eram essas relações constantes do Brasil com as nações que tinham o espanhol como língua oficial (e 
nacional)? Essa pergunta parece crucial numa pesquisa que propõe estudar a incorporação da língua no ensino secundário e a obra de Nascentes produzida como efeito desse acontecimento glotopolítico e, simultaneamente, estudar o tempo e a sociedade em que foi produzida, isto é, as condições sócio-históricas de produção.

Para tanto, abordamos as ideias (e os confrontos) da diplomacia brasileira a respeito das relações internacionais e dos ordenamentos regionais possíveis no continente, convocando duas figuras de destaque das primeiras décadas posteriores à independência: 0 Barão de Rio Branco (e alinhado com ele, Joaquim Nabuco) e Oliveira Lima, cujas posições contrapostas com relação à política externa do Brasil representam os embates políticos daqueles anos. Buscamos mapear representações e discursos em jogo sobre os países da América hispânica - muito fortes nessas primeiras décadas do século XX, mas que permanecem ao longo de todo o século - e os possíveis efeitos nas indagações e hipóteses que esta pesquisa levanta, especialmente ao pensarmos que a despeito dos diversos decretos e leis, e das tentativas de ampliar o espaço/tempo da língua na escola, o espanhol não chegou a ocupar o lugar e a ter a potência que essas justificativas pareciam sempre lhe atribuir.

Essas representações sobre os países da América Latina têm sido objeto de estudo de um grupo de pesquisadores do campo da história social ${ }^{34}$, no entanto, têm sido abordadas de forma isolada nos estudos da linguagem, especialmente, para pensar a inclusão, a permanência e a exclusão da língua espanhola do sistema educativo nas décadas iniciais do século XX. Por um lado, vale fazer menção a estudos como os de Prado (2001), que discutem a elaboração de um discurso político, no Brasil do século XIX, que fundou uma interpretação brasileira sobre o mundo hispano-americano, contribuindo, pela repetição, para a constituição de um imaginário que, como afirma a autora, acabou forjando uma memória coletiva sobre a outra América, que a dissocia e separa do Brasil.

Segundo Prado, os ideólogos do Império defendiam a monarquia que se opunha às repúblicas caóticas da parte espanhola, deixando clara a diferença entre o Brasil e os demais países da América do Sul. A autora afirma ainda que a instalação da República, que em tese deveria inaugurar uma mudança nessas relações, manteve os mesmos argumentos, dando continuidade a esse imaginário do Brasil e da “outra” América Latina

\footnotetext{
34 Prado (2000, 2001), Capelato (2000, 2005), Baggio (1998), Reis (2008), dentre outros. Trabalhos que podem ser colocados em relação com os discursos sobre o mito da "Ilha Brasil" - segundo o qual o país, originalmente uma imensa ilha envolvida pelas águas dos rios Amazonas e Prata, formaria sozinho um continente -, recuperado pelo monarquista Eduardo Prado para salientar a singularidade do Brasil em relação ao restante da América. Como afirma Capelato (2000), Eduardo Prado foi um dos autores que mais colaborou para a desqualificação da América hispânica. Para o monarquista, diz a historiadora (ibid., p. 293), o Brasil português em nada se igualava à América espanhola. Cabe registrar também o trabalho de Rodrigues (2012), que colocou esse mito no campo de reflexão sobre a língua espanhola.
} 
ou, no dizer de Capelato (2000, p. 290), do Brasil “fora da América Latina”. Mesmo com o advento da República e com a possibilidade do Brasil deixar de ser "a flor exótica" entre os países do continente (como registramos anteriormente em palavras de Fausto e Devoto) o imaginário perpetuou certas representações diante das quais cabe perguntar: em que medida esse imaginário do Brasil fora da América Latina não afetou a realização de um verdadeiro programa de inclusão da língua na escola?

Além desse imaginário com relação aos países da América Latina e em meio a esses embates políticos alinham-se as aproximações que, com o advento da República e, especialmente, na década de gestão do Barão do Rio Branco a frente do Itamaraty (19021912), o Brasil teve com os Estados Unidos. Esse período abriu uma era de marcada influência norte-americana, estimulando "a reflexão sobre a posição brasileira face de todo o continente” (Cândido, 2004, p. 145). Esse alinhamento com os Estados Unidos criou "um novo sulco na trilha que afastava o Brasil dos países hispano-americanos" (Prado, 2001, p. 140).

Como já afirmamos, na diplomacia brasileira existia outro grupo, encabeçado por Oliveira Lima que, em confronto com o anterior, propunha a aproximação do Brasil aos países da América Latina, especialmente para se opor aos perigos da política imperialista dos EUA (Oliveira Lima, 1907, 1920, 1953). A esse respeito é importante esclarecer que esse diplomata defendia a monarquia e mais do que por uma identificação com os países hispano-falantes, essa aproximação buscava frear o avanço dos Estados Unidos no Brasil, um avanço que se perpetuava já desde começos do século XIX com a Doutrina Monroe ${ }^{35}$.

No recorte dos anos 1920 abordado neste capítulo, o Brasil ainda vivia os efeitos da década em que o Barão do Rio Branco tinha dirigido o Itamaraty (1902-1912), imprimindo rumos que marcaram a política externa do Brasil ao longo do século XX (Lessa, 2012, Fausto, 2006). Em maio de 1915 foi assinado, depois de uma década de tratativas, o tratado ABC. O acordo significava uma aliança estratégica entre Argentina,

\footnotetext{
${ }^{35}$ A Doutrina Monroe datava de 1823 e foi aceita sem muita resistência pelos países latino-americanos, preocupados e empenhados nas suas independências políticas (Sampaio Malan, 1984). Justo (1983) assinala que a Doutrina tinha uma dupla interpretação: "protectora y agresiva" e reproduz palavras do general argentino Alvear, quem nos anos da entrada em vigor da Doutrina era ministro de Rosas (governador da província de Buenos Aires) em Estados Unidos. As palavras transmitem a preocupação diante do avanço imperialista propiciado pela doutrina. Diz Alvear: "poco más de medio siglo ha bastado para que a su política simpática y protectora hacia el resto de la América, haya sucedido una hostil y ambiciosa”, e conclui: "una República Americana considerada hasta ahora como la protectora de las demás, se convierte de pronto en el enemigo más temible, supuesto que todos sus planes de engrandecimiento se fundan en todo el resto de América como presa más fácil de devorar” (apud Justo, p. 27). Após a anexação de Texas, Alvear é categórico: "este pueblo se lanza y continuará en la carrera de las usurpaciones sin que sea posible contenerlo por otros medios que no sean la fuerza y poder que se empleen resistiéndole" (ibid.).
} 
Brasil e Chile, tentando limitar a carreira armamentista dos três países e comprometendo-os à solução dos conflitos por via da arbitragem ou da mediação (Dalponte, Marinkeff, 2009) ${ }^{36}$. Embora assinado em 1915, o acordo faz parte dos debates que aconteceram durante a gestão do Barão do Rio Branco no Ministério das Relações exteriores do Brasil, quem já tinha proposto um projeto semelhante, em 1909. Para o diplomata, a integração com esses dois países da região era um dos principais eixos das relações externas do país; o outro, de maior importância e forte marca da sua gestão, estava nas relações com os Estados Unidos (Bueno, 2012). Lessa (2012) afirma que durante a gestão de Rio Branco concluiu-se a migração do Brasil para o sistema de poder daquele país, assumindo as relações brasileiro-norte-americanas um lugar central $^{37}$. A partir de então, segundo o autor, o Brasil estaria alinhado à visão de mundo da grande potência hemisférica. Essa política levada adiante por Rio Branco decorreu da aspiração, por um lado, em diferenciar o Brasil do conjunto de nações do segmento sul do hemisfério (nações que o "cercavam”, pensamos retomando Nascentes), identificadas com convulsões políticas e insolvência financeira (Bueno, 2012) e, por outro, em colocar o país numa posição hegemônica nessa região sul do continente.

A historiografia das relações internacionais do Brasil tem visões divergentes sobre as justificativas para esse estreitamento dos laços com os EUA. Segundo Conduru (1998), as relações comerciais entre os dois países (mais do que os laços políticos e diplomáticos), teriam sido o fator determinante dessa política de aproximação. Naqueles anos, o mercado norte-americano era o principal consumidor das exportações brasileiras. Seja por uns motivos ou por outros (as relações comerciais ou os laços políticos e diplomáticos), segundo o Barão do Rio Branco, a possibilidade de união da América hispânica para se contrapor aos EUA era inútil (Bueno, 2012).

Assim, o Brasil se alinhava muito cedo ao movimento pan-americanista e expansionista dos EUA (que já vinha desde começos do século XIX com a Doutrina Monroe) em um momento em que o contexto regional sul-americano punha resistência ao

\footnotetext{
${ }^{36}$ Segundo Dalponte e Marinkeff (2009), o tratado só foi ratificado pelo Brasil. Na Argentina, a oposição era no sentido de que pudesse ser percebido pelos outros países da América do Sul como uma aliança militar ofensiva e, apesar das pressões dos Estados Unidos para que não fosse ratificado, foi aprovado no Senado, mas freado na câmara dos Deputados. No caso chileno, o Congresso rechaçou o tratado argumentando que não satisfazia os interesses nacionais a partir dos quais a iniciativa tinha sido aprovada. Ao longo da década de 1920 houve algumas iniciativas do Chile para dar um novo impulso, mas só a partir de 1946, o "Novo ABC" é promovido por Perón, quem já ocupava a presidência argentina. Desta vez era uma proposta que, como afirmam os autores mencionados, não buscava unicamente evitar a guerra, mas impulsionar explicitamente a integração.

${ }^{37}$ Nessa direção, Fausto et al. (2006) defende que o eixo diplomático se deslocou de Londres para Washington.
} 
avanço imperialista daquele país ${ }^{38}$. Como já foi dito, o debate sobre o pan-americanismo e as relações da América Latina (fundamentalmente do Brasil) com os EUA criou embates entre importantes intelectuais brasileiros: de um lado, os que eram críticos à política expansionista dos EUA (Eduardo Prado, Oliveira Lima, José Veríssimo, Manoel Bomfim), de outro, defensores ardorosos do pan-americanismo (Rio Branco, Joaquim Nabuco, Artur Orlando, Euclides da Cunha) (Baggio, 1998).

Na primeira década do século XX, Oliveira Lima escreve Pan-americanismo (Monroe, Bolívar, Roosevelt) (1907), um livro no qual ataca abertamente a política externa dos Estados Unidos, denunciando o caráter imperialista e mostrando os perigos futuros para o Brasil e para a América Latina, como afirma Prado (2001). No texto, o autor faz algumas considerações previas à que seria a terceira sessão de reunião das duas Américas, no Rio de Janeiro (após as acontecidas em Washington e México). Dentre essas considerações se refere ao "fermento fecundo de discórdia aguda" (Oliveira Lima, 1907, p. 33) que levaria à reunião a "pretensão insistentemente aventada pelo presidente dos Estados Unidos (...) de tornar efetiva a tutela americana, moral até ser material, sobre o resto do continente independente”. Na leitura do texto é possível perceber as preocupações do diplomata com relação às transformações da Doutrina Monroe, compreendida por ele como um "instrumento de utilidade continental” cuja feição estava sendo alterada. O que preocupava Oliveira Lima era que de "arma de salvaguarda” a Doutrina se transformasse em “arma de subjugação, quiçá de domínio por anexações” (ibid., p. 35). Os recortes que apresentamos são muito claros enquanto às preocupações do diplomata:

\begin{abstract}
Os Estados Unidos já queriam em tempo de Monroe, exatamente como agora em tempo de Roosevelt, ser um acima de todos, e por isso fizeram constantemente ouvidos de mercador às reivindicações e acenos de camaradagem de suas irmãs latinas (ibid., p. 39).
\end{abstract}

A doutrina de Monroe não mudou com o desenvolvimento dos Estados Unidos: transformou-se, envolvendo-se. Na essência é sempre a mesma, feita de ciúme e de ambição, porém, indispensável quando surgiu, e fatal no seu presente aspecto. Foi, no seu início, defensiva, e, pela continuação, passou, naturalmente, à ofensiva, como acontece quando se ganha forças para alcançar o que se cobiça (ibid., p. 41)

É força ter presente que a doutrina de Monroe só veda conquistas na América aos europeus, não as veda aos americanos do norte, pelo menos enquanto for exclusiva a doutrina; e se esses na própria Europa, e agora até no Estado

\footnotetext{
${ }^{38}$ Esse movimento é evidente na anexação do norte do México, e retomado a partir de 1898 com a intervenção norte-americana na guerra hispano-cubana. Vale lembrar que é de 1900 o Ariel de Rodó, um texto inspirado, ao menos em parte, pelo avance imperialista dos EUA (Prado, 2001). Na América Latina esse movimento expansionista resultou numa matriz discursiva antiimperialista que levou à valoração da cultura hispânica e ao questionamento da doutrina Monroe (Arnoux, Del Valle, 2015), reforçando essa separação entre o Brasil e a “outra” América Latina.
} 
Livre do Congo, estão em cada passo intervindo como agentes, porque deixariam na América Latina de exercer a função tutelar que se reservaram? (ibid., p. 99).

Se as colocações do autor são claras com relação às ambições dos Estados Unidos, também são claras sobre as resistências que as "Repúblicas espanholas de América do Sul” faziam àquela expansão e sobre as aspirações que o Brasil tinha, buscando dividir a hegemonia hemisférica com os Estados Unidos. Vale a pena, mais uma vez, ler as palavras do autor pela clareza e força sobre as questões colocadas:

\begin{abstract}
As Repúblicas espanholas de América do Sul, como a Argentina e o Chile à frente, fazem tacitamente causa comum na resistência contra aquela extensão, que se lhes afigura perigosa para a sua soberania. O Brasil, porém, que tem consciência de ser um país maior, mais ordeiro, mais progressivo do que qualquer dos seus vizinhos, sente que nada tem a temer e até se sente com vigor para aspirar a dividir com os Estados Unidos a "hegemonia hemisférica” (ibid., p. 42).

Os Estados Unidos procuram com toda a razão alargar a sua esfera mercantil no continente sul, o que é lícito e até louvável, alegando, não injustificadamente no nosso caso, que são eles os grandes compradores do nosso café, o que, contudo, não autorizaria a tornarem-se os compradores da nossa absoluta autonomia política (ibid., p. 44).
\end{abstract}

Ainda antes, numa metáfora contundente sintetizava suas preocupações:

Deixar que alguém nos entre em casa, para dirigir discricionariamente a sua economia e até as nossas relações, não é muito diferente de presenteá-lo com a casa e seus pertences (ibid., p. 35).

Mas, se abrimos a reflexão sobre o Brasil e as relações internacionais com os países da América Latina e com os Estados Unidos nesse começo do século XX, e sobre as representações que perpassam o imaginário de época, é porque nos parece interessante pensar a relação entre os discursos e debates dos intelectuais e da diplomacia brasileira relacionados à política exterior do Brasil e a legislação produzida pelo Estado com a consequente incorporação da língua espanhola no Colégio Pedro II que permaneceu apenas cinco anos como disciplina optativa. Com esse imaginário de época sobre os países da América Latina que tentamos apresentar sucintamente, podemos nos perguntar se existia um interesse forte, por parte do Brasil, para a inclusão da língua na escola e mais especificamente, no Colégio que formava essa classe dirigente.

Aqui vale a pena retomar indagações que Prado fez no final do trabalho já citado com relação a outro momento da história. Em 2001, a autora se perguntava se a criação do Mercosul levaria a mudanças na esfera das relações culturais, se seria possível transformar velhas imagens e ideias e se isso levaria à elaboração, no Brasil, de outras concepções sobre a América Latina. Prado (2001, p. 147) indagava sobre as 
possibilidades concretas para que surgisse uma nova visão brasileira com relação a essa outra América, “tão próxima e, ao mesmo tempo, tão distante”. Como vemos, para a autora, esse imaginário atravessara o século $\mathrm{XX}$ e, por isso, se perguntava sobre as possibilidades de mudanças. Essa série de indagações parece bastante produtiva para as perguntas formuladas neste trabalho. Entendemos que essas representações e discursos que atravessaram todo o século XX podem lançar luz nas indagações e incógnitas despertadas por uma reflexão contemporânea (que constitui um dos pontos de partida deste trabalho) sobre a história e a memória sobre o espanhol no Brasil, e sobre as muitas contradições identificadas nesse percurso ${ }^{39}$.

Essas questões nos levam a mais uma pergunta que fazemos inspirados em afirmações de Arnoux e Del Valle (2010, p. 8): em que medida o ensino de espanhol no Brasil e o processo de gramatização da língua que têm esses acontecimentos inaugurais em 1920 estão marcados pelos diferentes projetos de integração que, inscritos em memórias diferentes, atravessam o século XX e XXI e, como efeito disso, marcados pelas tensões e contradições surgidas desses embates? Arnoux e Del Valle (2010, p. 8 e 22) afirmam que "latinoamericanismo" e "panamericanismo" são vocábulos que designam dois projetos políticos contrapostos que apelam a memórias diferentes. Segundo os autores, o "latinoamericanismo" "remite a las diferentes tentativas que, con posterioridad a las guerras de la independencia hispanoamericana, buscaron unir los países ubicados al Sur del Río Grande”. Por sua vez, o "panamericanismo" "propone la integración del continente americano bajo la hegemonía norteamericana” (Arnoux, Del Valle, ibid., p. 22).

Ao longo do trabalho retomaremos essas questões que, entendemos, são cruciais para propormos possíveis interpretações sobre o modo como a presença da língua espanhola como disciplina oscilou (e oscila) no sistema educativo e sobre o processo de gramatização que a instrumentaliza para o seu ensino. Não só essas relações internacionais parecem cruciais, como também o modo como ao longo da historia do

39 Como afirmamos na Introdução desta tese, uma das indagações centrais da pesquisa surge de uma reflexão contemporânea: compreender por que nem mesmo nos momentos nos quais houve gestos de projeção na América do Sul de um imaginário latino-americanista, como foi o contexto da promulgação da lei 11.161, em 2005, que estabeleceu a oferta obrigatória da língua espanhola nas escolas do ensino médio e a matrícula facultativa por parte dos alunos, conseguiu um verdadeiro enraizamento da língua na escola. Por isso, no começo do trabalho nos perguntávamos sobre os aspectos da história do Brasil e da memória sobre a língua que foram tendo efeitos nesse pouco sucesso ou nessa frágil presença da língua na escola. De qualquer forma, é interessante observar que nos momentos em que diferentes governos tiveram uma maior aproximação aos países da América Latina, em conjunturas marcadas por jogos diversos de interesses, como foi o caso do governo Vargas (1930-1945), do governo Kubitschek (1956-1961) e do governo Lula (20032011), a língua espanhola ocupou outro lugar ou, ao menos, foi objeto de tentativas nesse sentido. 
Brasil as elites propõem uma maior ou menor aproximação aos países da América Latina. As representações em jogo não são inocentes e o modo como é anunciada a incorporação da língua no Colégio Pedro II, por meio de um decreto que faz parte da lei orçamentária dos Estados Unidos do Brasil (Lei 3.674 de 7 de janeiro de 1919), no qual se menciona o aumento da verba destinada ao Colégio para cobrir as despesas decorrentes da criação da cadeira de espanhol, parece ser uma pista sobre o modo como o Estado encarou esse gesto glotopolítico.

Após a inclusão da língua no Colégio, abre-se o primeiro concurso oficial (realizado entre os dias 9 e 23 de setembro de 1919) ${ }^{40}$ para a cadeira de espanhol, assumida no ano seguinte por Antenor Nascentes ${ }^{41}$ que, como era comum à época, produz o material didático que daria suporte ao curso. Levando em consideração que a Gramática é produzida por um sujeito constituído ideologicamente em condições históricas específicas, na próxima seção iluminaremos aspectos da biografia e da trajetória intelectual do autor, à luz da sociedade específica em que acontece.

\section{O autor ${ }^{42}$ : biografia, filiações teóricas e trajetória intelectual}

Antenor Nascentes - filólogo, gramático e lexicógrafo brasileiro - participa desde jovem dos debates sobre os rumos que deveria seguir o português no Brasil. A produção científica vinculada a essa língua e sua labor docente fizeram com que passasse à história das Letras no Brasil (Quintela, Da Costa, 2013). O autor da Gramática nasceu no Rio de Janeiro em 17 de junho de 1886, dois anos antes da Lei Áurea que, em 13 de maio de 1888, aboliu a escravidão. Em meados do século XIX, a cidade foi a maior no hemisfério em população escrava e chegou a ser o maior terminal de tráfico do Atlântico (Reis, 2000). Esses escravizados “marcaram em profundidade os costumes, o imaginário, a cultura e até, através de uma intensa miscigenação, o próprio perfil étnico-racial da população”, diz Reis (ibid., p. 244). Nessa cidade nasceu, cresceu, estudou e se formou Nascentes.

\footnotetext{
${ }^{40}$ Para um estudo mais detalhado sobre o concurso, sobre os candidatos e sobre o modo como a imprensa acompanhou esse acontecimento, remetemos aos trabalhos de Guimarães (2014) e Recuero (2017).

${ }^{41} \mathrm{O}$ anuncio oficial sobre a classificação dos participantes saiu no dia 26 de setembro (Guimarães, 2014).

${ }^{42}$ As informações para a síntese biográfica que apresentamos foram retiradas de uma série de trabalhos e de forma mais específica de Silva (2012).
} 
O seu sobrenome advém da família da qual sua avó paterna foi escrava, como era costume à época. Negro, de família pobre, fez o curso primário numa escola pública e tendo tirado a nota máxima nos exames de conclusão, teve assegurado o ingresso gratuito no Colégio Pedro II, como era praxe na época (Ribeiro, 2014), onde cursou como aluno bolsista integral o ensino médio - naqueles anos o colégio não era gratuito. Contou para isso com a ajuda da Profa. Dona Amélia Costa quem, percebendo a vontade de estudar do menino e a falta de condições financeiras da família, prontificou-se a ajudar para que Nascentes não abandonasse a escola (Alves, 2006). Dedicado e disciplinado nos estudos, recebeu o Prêmio Panteão Escolar pelo seu desempenho. Nascentes parecia ter vislumbrado desde pequeno, por um lado, o que Schwarcz (2017, p. 24) assinala como uma maneira eficaz de distinção e ascenso social naqueles anos: a formação educacional e, por outro, que “as letras habilitavam [os mestiços] a penetrar na tradição do grupo dominante” (Silva Neto, 1963, apud Lucchesi, 2015, p. 120).

Sua formação acadêmica continuou na mesma instituição, no curso de Ciências e Letras, tornando-se bacharel em $1902^{43}$ e na Faculdade de Ciências Jurídicas e Sociais do Rio de Janeiro, sediada no Colégio Pedro II, onde se formou em $1908^{44}$. Após essa formação não teve dificuldades em passar em concursos públicos: foi funcionário dos Correios e Telégrafos e por ter se formado em direito, concursou na Secretaria do Ministério da Justiça e Negócios Interiores (1904). Antes de ingressar ao Colégio Pedro II para assumir a cadeira de espanhol, foi professor de escolas particulares. Posteriormente participou das discussões e elaboração de vários programas de ensino de importantes instituições de nível superior e foi convidado por Capanema para dar aula na Universidade, cargo que não aceitou para poder terminar a carreira de professor no Colégio Pedro $\mathrm{II}^{45}$.

Uma abordagem que leve em conta as determinações históricas dos processos de significação, como a que propomos neste trabalho, e fazendo parte delas a história de

\footnotetext{
${ }^{43}$ Obteve matrícula gratuita na faculdade como prêmio por ter revelado o melhor aproveitamento no curso secundário.

${ }^{44}$ Em entrevista concedida a Pedro Bloch e apresentada em parte, em 2006, no X Congresso de Linguística e Filologia, Nascentes afirma que conseguiu ser matriculado de graça na faculdade - onde a matrícula era de trinta mil-réis - em virtude das suas notas e da apresentação de um atestado de pobreza.

${ }^{45}$ Bechara (2003, p. 8) transcreve parte do discurso pronunciado por Nascentes em 1952 quando lhe foi entregue o título de professor emérito do Colégio Pedro II. Assim falara o autor da Gramática naquela ocasião: "minha carreira aproximava-se de seu fim quando se criou a Faculdade Nacional de Filosofia. O Ministro Dr. Gustavo Capanema mostrou desejo de me ver na cadeira de língua e literatura espanhola da novel Faculdade, em caráter efetivo, aproveitando o meu concurso aqui. Eu já pensava em deixar o magistério. Quando o ministro me fez a proposta eu respondi: perdoe-me V. Exa. Não abandono o meu Colégio centenário por uma Faculdade recém criada. Já penso em sair. Quero acabar onde comecei”.
} 
vida (o sujeito e sua individualidade, a infância e a vida familiar), deve se precaver da ilusão de transparência do real, da lógica dos acontecimentos, da linearidade progressiva, de imaginar a vida como um todo coerente e coeso (Montagner, 2007) ${ }^{46}$. Indagar a vida do autor da Gramática nos coloca, por um lado, diante de um sujeito inserido numa sociedade específica (inserção que buscamos compreender) e, ao mesmo tempo, diante de dualidades que a conformam dialeticamente: indivíduo/sociedade, ação individual/coletiva, liberdade/determinismo (ibid.).

Diversos aspectos da biografia do autor no contexto específico da sociedade brasileira daqueles anos nos permitem iluminar essas relações dialéticas que sempre colocam desafios e limites interpretativos ao pesquisador, mas que possibilitam uma reflexão mais aprofundada sobre o "lugar” desse sujeito (Pêcheux [1969] 2010b). Nascentes era negro e era neto de uma escrava liberta, num país onde como assinalam Schwarcz e Starling (2015, p. 343) “a partir de argumentos biológicos e sociais se apontava para um futuro branco e pacífico, com os negros e mulatos desaparecendo para dar lugar a uma civilização ordenada e crescentemente branqueada”. As autoras fazem essas afirmações a partir das palavras formuladas pelo diretor do Museu Nacional do Rio do Janeiro, João Batista de Lacerda, em trabalho apresentado no I Congresso Internacional de Raças (Londres, 1911). Nesse trabalho, Lacerda afirmava que era lógico supor que na entrada do novo século os mestiços teriam desaparecido do Brasil, fato que coincidiria com a extinção paralela da raça negra (apud Schwarcz, Starling, 2015, p. 343 $)^{47}$. Naqueles anos, a eugenia ${ }^{48}$ estava na ordem do dia e o "racismo e a exclusão social e política pautavam”, segundo Napolitano (2017, p. 53), “o pensamento das oligarquias republicanas dominantes”. Seria esse um dado menor na trajetória intelectual de um autor negro nessa sociedade específica e nesse Colégio de elite?

Não seria essa uma questão em um país que quase um século depois, em 2019, continua fazendo campanhas publicitárias em que a educação funciona como uma espécie de branqueamento racial ${ }^{49}$ ? Como marcam esses aspectos da sua vida a sua

\footnotetext{
${ }^{46} \mathrm{O}$ autor toma como base os trabalhos de Bourdieu em que o sociólogo francês estuda materiais biográficos.

${ }^{47}$ Não podemos desconhecer a violência simbólica de discursos como esse e perguntar: ao final, por meio de que processo aconteceria esse branqueamento? Somado aos argumentos sobre o branqueamento, desde meados da década de 1870, as teorias deterministas raciais vinham ganhando força (Schwarcz, Gomes, 2018). Assim, a biologia introduzia uma diferença ainda mais radical entre os homens (ibid.).

${ }^{48}$ Como afirma Schwarcz (2018, p. 406), "o saber sobre as raças levou a um `ideal político' que previa a submissão ou eliminação das 'raças inferiores': a eugenia”.

49 A nota "Campanha do MEC é acusada de racismo ao embranquecer mulher negra", publicada em 15/6/2019 assinala que no século XXI, o racismo, expresso a partir do próprio Estado, continua sendo uma questão. Não o seria um século atrás? Disponível em: www.metropoles.com/brasil/educacaobr/campanha-do-mec-e-acusada-de-racismo-ao-embranquecer-mulher-negra. Acesso em: 18/6/2019. Essa
} 
trajetória intelectual e o modo como o autor se inserta num campo científico por meio da sua atuação e sua produção teórica?

Ter essas questões presentes nos permitiu rastrear em diversas falas e escritos do autor e de comentaristas da sua obra algumas poucas pistas interessantes, detalhes menos evidentes (Ginzburg, 1998), nos quais Nascentes faz referência às dificuldades de um descendente de negro. Duas dessas pistas surgem na apresentação de João Bortolanza “Antenor Nascentes. Testemunhos e considerações etimológicas” (2006) ${ }^{50}$, um trabalho que traz depoimentos e testemunhos da presença de Nascentes em Paraná e registra as lembranças de alunos do curso "Língua portuguesa: ortografia e estruturalismo", ministrado pelo autor de 20 a 23 de junho de 1967, na Faculdade Estadual de Filosofia, Ciências e Letras de Londrina.

Nelso Attilio Ubialdi, um dos alunos do curso, conta que Nascentes "dizia que era o único sul-americano convidado na Europa para tratar de assuntos de Filologia” e acrescenta que o autor "lia em português com desenvoltura textos escritos em alemão ${ }^{51}$, deixando os ouvintes boquiabertos”. “Queria mostrar”, explicava o próprio Nascentes, "que um descendente de negro era capaz e que o brasileiro não era o que imaginavam muitos” (apud. Bortolanza, 2006, p. 2). Joaquim Carvalho da Silva, outro aluno do curso, conta que o acompanhou em diversos passeios e que neles "muito comentou sobre como era discriminado por ser descendente de negro” (ibid.). Finalmente, mais uma pista aparece na Seção Memória de estudante, escrita por Fernando Segismundo (1987) em edição comemorativa do sesquicentenário do Colégio (1837-1987). O autor dessas memórias sobre Nascentes afirma que "nascera mulato e pobre e foi aluno laureado do Colégio Pedro II. Complexado devido à cor - retroceda-se aos fins do século passado - impôs-se toda sorte de sacrifícios para obter a cátedra” (ibid., p. 44-45). Em outras

campanha do Estado teve repercussão em diferentes lugares do mundo. Na Argentina, o jornal Página12, também publicou uma nota sobre a polêmica publicidade do Ministério de Educação: "La mujer negra que se transforma en blanca, la campaña racista de Bolsonaro”. Disponível em: www.pagina12.com.ar/201088-la-mujer-negra-que-se-transforma-en-blanca-la-campana-racist. Acesso: 18/6/2019.

${ }^{50}$ Texto apresentado no X Congresso Nacional de Linguística e Filologia e transcrito na série de Cadernos: Serie X, Número 17, em homenagem a Antenor Nascentes, 2006. Disponível em: http://www.filologia.org.br/xcnlf/17/04.htm. Acesso em: 15 de setembro de 2017.

${ }^{51}$ Na entrevista concedida a Pedro Bloch, já mencionada - publicada em 2006 nos Cadernos do X Congresso Nacional de Linguística e Filologia, Volume X, no. 17 -, Antenor Nascentes afirma que Said Ali tinha sido o magnífico professor de alemão que saiu falando do colégio. Isso dá uma pista do nível da formação linguística no começo do século XX, no Colégio Pedro II. 
palavras, Nascentes foi o que os estigmas da cor e da pobreza o teriam impossibilitado de ser: um aluno laureado, não sem muitos sacrifícios e disciplina no estudo ${ }^{52}$.

Os recortes apresentados acima abordam a questão da cor e da classe social de forma explícita. No entanto, no que apresentamos a seguir, extraído da Introdução do Dicionário Etimológico (Nascentes, 1931), o autor busca defender seu trabalho, seu conhecimento e contesta aos que o questionaram quando, após ter sido fechada a cadeira de espanhol no Colégio Pedro II, em 1925, assumiu a de português sem fazer concurso. Diz Nascentes na Introdução:

Passei para a cadeira de português sem concurso. Grave pecado! Em nosso país, um concurso, embora medíocre, embora apagado, é a única prova de competência. E eu não havia dado esta prova! (ibid., p. X).

E alguns parágrafos adiante, continua:

Pois bem. Não fiz concurso para a cadeira de português, mas o fiz para uma língua irmã, havendo escrito um ensaio de fonética diferencial lusocastelhana, havendo vertido para o espanhol um trecho difícil de um sermão de Vieira. Desde 1904 ensino particularmente a língua que recebi no berço. Examinei em preparatórios desde 1916. Examinei candidatos a livre-docente e a catedrático de português. Escrevi sobre redação oficial, fiz um estudo dialectológico do linguajar da capital do país, elaborei uma série de livros didáticos que vão das noções sobre o alfabeto, em começo de curso primário, à estilística e à literatura, no limiar do curso superior. Nada disto foi suficiente?

Escrevo então este dicionário (ibid.).

O tom é claramente contestatório e de uma mostra de méritos. O Dicionário, obra chave dos estudos etimológicos da língua, fora montado a partir das mais de 40.000 fichas que Nascentes escrevera a partir de 1911, quando "na impossibilidade de adquirir o Dicionário de Adolfo Coelho” - conta nessa mesma Introdução - resolveu “fazer um pequeno vocabulário etimológico para [seu] uso próprio” (ibid.).

Além disso, ao afirmar que "um concurso, embora medíocre, embora apagado, é a única prova de competência”, parece questionar, em certa medida, a instância institucional. Consciente de que nessas críticas à falta de concurso para a cadeira de português seus méritos não estavam sendo reconhecidos, faz uma longa enumeração de tarefas já realizadas que, entende, o habilitariam a ocupar essa cadeira - “desde 1904 ensino a língua”, “examinei em preparatórios”, “examinei candidatos a livre-docente e a catedrático de português”, “escrevi sobre redação oficial”, “fiz um estudo dialectológico

\footnotetext{
${ }^{52}$ Na entrevista mencionada na nota anterior, Nascentes se referia assim a um desses sacrifícios: "para conseguir comprar as Historias da Carrocinha vim a pé da cidade para casa durante um mês juntando um tostão por dia” (Bloch, 2006, p. 2).
} 
do linguajar da capital”, “elaborei uma série de livros didáticos”. E, finalmente, reconhecendo que isso não havia sido suficiente: “escrevo então este dicionário”.

Duas décadas após a publicação dessa obra, no discurso pronunciado ao receber o título de professor emérito do Colégio, em 1952, volta a fazer referência à transferência para a cadeira de português, quando fora fechada a de espanhol, em 1925. Passados mais de vinte cinco anos desse fechamento assim fazia referência ao acontecimento: "minha transferência para português deu que falar. Respondi a estes murmuradores com a publicação do Dicionário Etimológico. O Dicionário valeu por um concurso" (apud Bechara, 2003, p. 8) ${ }^{53}$.

O autor, desde um lugar subalterno na sociedade das primeiras décadas do século XX, tinha chegado por concurso à cadeira de uma língua aparentemente também projetada em uma posição subalterna (o espanhol era facultativo, ficando em uma posição diferente com relação às outras línguas do currículo plurilíngue da época). E a partir dessa posição, por um lado, tenta conseguir em conversa com o Ministro do interior, embora sem sucesso, que o espanhol ascenda à categoria das outras línguas ${ }^{54} \mathrm{e}$, por outro, chega (sem concurso) à cadeira de português (“grave pecado!”): a língua nacional, para muitos a língua herdada do Império e que ele tinha recebido "no berço”. Certos setores da elite não perdoariam esse fato levado adiante numa instituição que, ela sim, parecia privilegiar os méritos mais do que qualquer outro aspecto social ou racial.

Ainda caberia pensar sobre outro aspecto já observado acima: em que medida a infância de Nascentes num entorno familiar, possível de ter sido linguísticamente heterogêneo ${ }^{55}$, favoreceu uma sensibilidade que permitiria que, como autor, reconhecesse uma língua em sua diversidade. Vale lembrar as palavras de Mattoso Câmara Jr., em um texto de 1972 que é re-publicado em 2014 no número XIV da Revista da Academia de Filologia, em homenagem a Antenor Nascentes, ao afirmar que o autor é reconhecido “pelo alto mérito de introduzir na escola secundária a língua materna na sua realidade oral (...)” (Mattoso Câmara Jr., 2014, p. 37), um aspecto que o coloca como um inovador na

\footnotetext{
${ }^{53}$ A retomada que o autor faz em 1931 e em 1952 sobre a sua nomeação para a cadeira de português, ocorrida em 1926, assinalam o que entendemos foi, em certa medida, um fato vivido de forma traumática. ${ }^{54}$ Na mesma Introdução do Dicionário Etimológico, Nascentes comenta: “A cadeira era facultativa, o que me trouxe os maiores dissabores. Os que lidam no magistério sabem como são estudadas as cadeiras obrigatórias e bem podem imaginar como o seria uma facultativa. Quando se planejou uma reforma do ensino em 1925, fui ao ministro do interior de então, o Dr. João Luiz Alves, e lhe expus a minha situação, pedindo a obrigatoriedade da cadeira" (1931, p. x).

${ }^{55}$ Não conseguimos acessar aspectos biográficos que nos permitam afirmar isso com mais certeza: como transcorreu a infância e juventude, se conviveu ou não com a sua avó, com a sua mãe. O trabalho de Silva (2012), talvez o que mais aprofundadamente aborda a biografia do autor, tampouco revela aspectos nessa direção.
} 
dialetologia ${ }^{56}$ e filologia brasileira. Nesse mesmo texto, referindo-se ao Idioma Nacional, um livro posterior à Gramática que analisamos, Mattoso Câmara Jr. afirma que "para compreender o alcance [dessa obra], é preciso que nos lembremos do que era o tratamento do assunto nas gramáticas escolares dos seus predecessores” e conclui: "não havia a percepção de uma língua oral, viva e cotidiana” (ibid. p. 39).

Determinado e ativo intelectual, a vastíssima produção de Nascentes atravessa 65 dos 86 anos vividos ${ }^{57}$, ao longo dos quais tem também uma intensa participação em instituições, comissões e conferências oficiais. Silva (2012), citando Barbadinho Neto (1990), apresenta alguns exemplos: foi membro da Comissão de Unificação da Ortografia Oficial (1924), da Conferência promovida pelo Instituto Histórico para tratar da grafia dos nomes geográficos (1924), da Academia Brasileira de Filologia e da Academia de Filologia de Lisboa ${ }^{58}$. Durante a presidência de Getúlio Vargas participa como conferencista dos eventos promovidos pelo Departamento de Imprensa e Propaganda (DIP) sobre “linguagem como fundamento da reconstrução nacional” (ibid.) e recebe o convite do Ministro Capanema para elaborar o vocabulário ortográfico da língua nacional ${ }^{59}$. Já durante a presidência de Juscelino Kubistchek, também participa

\footnotetext{
${ }^{56}$ Em palavras de Domingues e Henriques (2014, p. 93): "se hoje já não é mais ponto de disputa o reconhecimento de que a variação em língua portuguesa ocorre em função de diferentes parâmetros no que tange aos dialetos (geográficos, sociais, etários, de gênero) e registros (graus de formalidade, modalidade e sintonia), atingindo todos os níveis do sistema (fonético, fonológico, morfológico, sintático, lexical e discursivo) devemos isso a um grupo pioneiro de estudiosos no qual se inclui Antenor Nascentes".

${ }^{57}$ Não pretendemos abordar aqui essa vasta obra já que foge aos objetivos deste trabalho, mas vale a pena citar algumas poucas palavras do prefácio de Serafim Silva Neto, do Tomo II do Dicionário Etimológico da língua portuguesa, de Antenor Nascentes (1952). Sobre o autor da obra, diz: "a sua curiosidade científica, ampla e variada, levou-o a muitos setores da Filologia portuguesa” (1952, p. 1). E faz a continuação uma enumeração das temáticas e das obras correspondentes: "desde os traços diferenciais dessa língua em relação ao espanhol” (Um ensaio de fonética diferencial luso-castelhana. Dos elementos gregos que se encontram no espanhol, tese de concurso, 1919); "até o português do Brasil” (O linguajar carioca, 1922); "à metodologia de ensino" (O Idioma Nacional, 1933); "à regência” (O problema da regência, 1944); "às frases feitas" (Tesouro da fraseologia, 1945); "à etimologia” (Dicionário etimológico, 1932), dentre outros.

${ }^{58}$ Um dado que nos parece especialmente significativo é o fato de Nascentes fazer parte das duas Academias: a Brasileira e a de Lisboa.

${ }^{59}$ Sobre essa obra específica, vale a pena um pequeno parêntese, já que tem uma relação estreita com questões que trataremos no próximo capítulo. Em 1941, Nascentes envia uma carta a Capanema acompanhada do original e de uma copia do Vocabulário Ortográfico da Língua Nacional (a obra encomendada). Nessa carta comenta que tomou por base o vocabulário existente: Vocabulário Ortoépico da Língua Portuguesa, organizado pela Academia Brasileira de Letras e Academia das Ciências de Lisboa. Explica que embora não tenha se afastado do acordo realizado entre as duas Academias, a tarefa fundamental que teve que empreender com o vocabulário das duas Academias "foi o de corrigir o que se me afigurou errado" ([1941], 2003h, p. 656). Depois, afirma, "procedi à supressão dos vocábulos que, no meu entender, não deviam figurar num vocabulário destinado a entender às necessidades atuais do Brasil” (ibid.). "Assim”, continua, "suprimí arcaísmos, neologismos não radicados, regionalismos de Portugal, africanismos e asiaticismos inúteis (...)" e, para concluir, explica na mesma carta: "finalmente, procurei preencher as lacunas incluindo muitos vocábulos encontrados em vários léxicos, mas ausentes do vocabulário acadêmico e adaptando vocábulos estrangeiros necessários e consagrados pelo uso” (ibid. p. 657).
} 
na elaboração da "Nomenclatura Gramatical Brasileira” (NGB) (Baldini, 1999). Como vemos, uma figura destacada, afetada pelas contradições que em qualquer momento histórico determinam uma sociedade particular e cuja atuação - intensa e próxima ao aparelho do Estado - atravessa importantes períodos políticos do Brasil.

Como afirmamos no começo do capítulo, nas décadas iniciais do século XX as disputas entre uma tradição portuguesa (homogênea, culta e estandardizada) "que pregava abertamente a submissão ao cânone gramatical português” (Lucchesi, 2015, p. 118) e as especificidades da língua no Brasil (diversificada nas suas muitas falas regionais) eram pauta de discussão. É em meio a essas disputas em torno à língua nacional brasileira que o autor se filia teoricamente e é em meio a elas que vai assumindo posições não só com relação à língua do/no Brasil, mas também, no tratamento dado à língua na Gramática de espanhol, escrita para ensinar a disciplina no Colégio Pedro II.

Desse modo, buscamos compreender a Gramática e a posição do autor à luz de várias redes de determinações. Se na primeira seção propusemos pensar o acontecimento que marcou a entrada do espanhol no Colégio Pedro II (que tem efeito direto na produção da obra) à luz da política exterior do Brasil e das relações internacionais com os países da América Latina e os Estados Unidos, e nesta, aspectos da biografia e da trajetória intelectual do autor à luz de uma sociedade específica, na próxima seção propomos uma escala interpretativa diferente que tenta compreender os efeitos de possíveis determinações institucionais. Para tanto, analisamos a obra à luz de uma tradição de ensino plurilíngue já existente no colégio, na qual, para as outras línguas estrangeiras, já tinham sido produzidos instrumentos linguísticos: livros e programas de estudo.

\section{Circulação de saberes: tradição e memória}

Como já foi dito, a entrada do espanhol no Colégio Pedro II em 1920 ampliou a grade curricular já existente de ensino plurilíngue. O fato de o espanhol ter sido a última língua incorporada ao aprendizado nos levou a pesquisar outra série de instrumentos linguísticos: os manuais e gramáticas utilizados no ensino das outras línguas. Essa análise permite pensar em que medida os diversos materiais que já circulavam no Colégio podem ter determinado, em certo grau, a elaboração da obra de Nascentes. Daí a proposta de pensarmos, em 3.1., como se alinha essa gramática específica de espanhol em uma 
tradição já existente, ou seja, em que medida a obra de Nascentes se aproxima ou se afasta dos modos em que as outras línguas são projetadas nos paratextos dos instrumentos linguísticos elaborados para o seu ensino. Obras contemporâneas à Gramática no uso em sala de aula, e produções que, inclusive num momento anterior, tinham participado da formação de Nascentes como aluno do Colégio.

A análise dessa série reafirmou a necessidade de refletir sobre as produções que tinham funcionado como fontes na elaboração da Gramática, aspecto que abordaremos em 3.2.

\subsection{A Gramática numa série plurilíngue}

Após a leitura dos manuais e/ou gramáticas disponíveis no Núcleo de Documentação e Memória do Colégio Pedro II (NUDOM) ${ }^{60}$, optamos por duas variáveis na seleção dos materiais que comporiam a série de análise: por um lado, que a produção fosse anterior à Gramática de Nascentes e, ao mesmo tempo, que as obras tivessem sido escritas por autores brasileiros, professores das línguas para as quais produziram as obras já desde a segunda metade do século XIX e, preferentemente, docentes do Colégio Pedro II. Dos livros selecionados, analisamos as introduções de dois compêndios de alemão - “Noções práticas da língua Allemãa” (1859) e “Noções teóricas da língua Allemãa” (1860), do professor Berthold Goldschmidt, produzidos especialmente para o Imperial Collégio de Pedro II -, e de dois livros de francês “Curso graduado de língua franceza” (1901), um método prático para aprender a língua franceza, de Henrique Monat e Gastão Ruch, professores no Gymnasio Nacional e "Primeiras Noções de Grammatica Franceza”, obra escrita por Carlos Ploetz e traduzida do alemão e adaptada à língua portuguesa por Said Ali (21 a ed., 1935) ${ }^{61}$. Para o caso do inglês, cabe registrar que os livros disponíveis eram todos posteriores a 1920.

$\mathrm{Na}$ análise da série, identificamos certas regularidades que atravessam as diversas obras: (i) a necessidade de instrumentos linguísticos escritos em português, (ii) a inclinação a um ensino prático que se afasta da língua clássica e reforça a proximidade com a língua falada e escrita (a língua em uso) e (iii) o contraste entre as línguas como uma das principais ferramentas de trabalho.

\footnotetext{
${ }^{60}$ Com o trabalho em andamento, encaminhamos uma consulta a esse núcleo para saber que materiais havia e se estariam disponíveis para pesquisa e fomos informados da existência de três livros de alemão do século XIX, quatorze de francês e treze de inglês.

${ }^{61}$ A $1{ }^{\mathrm{a}}$ edição é de 1893.
} 
Na Introdução do livro “Noções práticas da língua Allemãa” (Goldschmidt, 1859), o autor afirma que desde o primeiro momento em que se dedicou ao ensino dessa língua, sentiu falta de uma gramática escrita em português. Suas palavras também deixam entrever as dificuldades técnicas para elaborar uma obra com essas características: "ha muito me teria encarregado de fazer desapparecer esta lacuna si, á grande difficuldade de obter no paiz impressões correctas da língua allemãa, não acrescesse ainda a extraordinaria carestia dessas impressões” (Goldschmidt, 1859, p. III). Goldschmidt manda imprimir as obras na Alemanha, desvanecendo as dificuldades e obtendo, segundo ele, "não somente uma impressão mais correcta, mas ainda por um preço mais módico” (ibid.). Essa opção por produzir manuais ou gramáticas em português, vai se repetir nos livros de francês e no próprio livro de Nascentes, fato que assinala também a importância atribuída nesse processo de gramatização à língua nacional. Said Ali, em "Primeiras Noções de Grammatica franceza”, obra de Carlos Ploetz, traduzida por ele do alemão e adaptada à língua portuguesa afirma que

\begin{abstract}
a falta de uma grammatica franceza elementar escripta em portuguez a qual, por meio de poucas regras, porém claras e concisas ensinasse de cada uma das partes d’ella, o estrictamente necessário para comprehender phenomenos mais communs da língua e, por outro lado, o desejo de prestar um serviço à instrucção pública, determinaram-me a traduzir e a apresentar ao publico um livro por onde os meninos poderão sem difficuldade iniciar o estudo da língua franceza e adquirir os conhecimentos essesnciais da grammatica para traduzirem ou verterem linguagem fácil sem commetterem graves erros (1935, p. 6).
\end{abstract}

Essas produções em português, regularidade que atravessa os livros de alemão, francês e espanhol, também deixariam mais autônomo o estudo dos alunos.

O segundo aspecto que aparece como regularidade é a necessidade de um “ensino prático” da língua e o lugar que ocupam nele os aspectos gramaticais. Goldschmidt (1859), no livro de alemão, compara o estudo das línguas com a evolução física de um recém nascido. Nesse sentido afirma que, assim como o bebê é amamentado ao nascer e sucumbiria caso não fossem observadas as leis da natureza e fosse alimentado com substancias pesadas ainda que mais nutritivas; do mesmo modo, para o estudo de qualquer ciência é importante, previamente, que o indivíduo tenha sido preparado pela instrução primaria e secundária, começando pelo mais fácil até chegar a compreender o mais difícil. E nessa linha de raciocínio, o autor afirma que ninguém contestará o fato que "a parte material da língua, isto é, sabel-a fallar, é a mais fácil” (Goldschmidt, 1859, p. VII), e apóia essa afirmação na facilidade do aprendizado da língua materna e de qualquer outra língua por parte da criança. 
Essas ideias são reforçadas no começo do segundo volume: "Noções teóricas da língua Allemãa” (1860), do professor Berthold Goldschmidt quem diz:

No primeiro volume desta grammatica, ou "Noções prácticas da língua allemãa” demostrei as vantagens do ensino practico das línguas precedendo o ensino theorico, não somente por ser aquelle mais adequado às forças do alumno, que começa a dedicar-se ao estudo de huma língua, mas ainda por ser o methodo natural em conformidade com o qual aprendemos a nossa língua vernácula, methodo este, por cujo intermedio e intelligencia se desenvolve progressivamente e se habitua ao estudo, para poder depois comprehender com facilidade a parte mais difícil da língua (Goldschmidt, 1960, p. v).

Nessa direção, na obra de Nascentes podemos $l \mathrm{le}^{62}$ :

O ensino prático de uma língua estrangeira deve ser feito pelo processo natural, que é o semelhante àquelle pelo qual uma criança aprende a falar a língua materna: ouvir e tentar falar. É assim que aprendem os imigrantes, é assim que aprendem os viajantes (1934, p. 116).

Como os imigrantes e os viajantes, também os alunos deveriam aprender a língua por um processo natural que implicava em ouvir e tentar falar.

Por sua vez, assim começam Monat e Ruch (1901) a introdução do "Curso Graduado de língua franceza”

O caráter prático dado ás cadeiras de línguas vivas do Gymnasio Nacional justifica a apresentação d’este livro despretencioso fundido nos moldes modernos, expressão da revolução feita pelo decreto de 8 de abril de 1899

- AO ESTUDO DAS LÍNGUAS VIVAS SERÁ DADA FEIÇÃO EMINENTEMENTE PRÁTICA. Art. 6 \& II (ibid., p. III).

Os autores anunciam um decreto revolucionário que teria imprimido o caráter prático ao ensino de línguas estrangeiras marcado por uma tradição que tinha na tradução das línguas a ferramenta central. Monat e Ruch afirmam que o caráter revolucionário estaria em afirmar que “o ensino será prático, mas esclarecido pela theoria” (ibid., p. IV).

Poucas regras e muitos exercícios, afirmam Monat e Ruch em defesa desse ensino prático. E continuam: “é o lemma, que a commissão encarregada pela Congregação de formular os programas dos cursos, estabeleceu de accordo com a orientação moderna no ensino de línguas” (ibid., p. III). Essa afirmação traz uma pista do funcionamento interno do Colégio. Uma comissão formulava os programas e a partir deles, os professores, ao

\footnotetext{
${ }^{62}$ A cita corresponde a uma seção - "O ensino prático de hespanhol” - que não estava presente na primeira edição, mas sim a partir da segunda (1928) - conforme observação realizada pela professora Luciana Freitas na defesa da presente tese. Atribuímos essa inclusão ao curto período que o autor teve entre a realização do concurso e o começo das aulas em 1920. O decreto de 1931 (como parte da Reforma de Francisco Campos) reforçaria a existência dessa seção, indicando o uso do método direto no ensino de línguas estrangeiras.
} 
igual que no caso de Nascentes, elaboravam os livros ${ }^{63}$. Insistindo com a mudança de paradigma, Monat e Ruch afirmam que até esse momento as línguas vivas se ensinavam pelos mesmos métodos que as mortas e que ao finalizar o curso, o aluno

conhece mil subtilezas, mil curiosidades grammaticaes, comprehende todo o mecanismo philologico, podendo com desembaraço accompanhar um termo, uma construção em sua evolução desde o estado atual até o seu ponto de partida; traduz admiravelmente os clássicos, mas difficilmente apanha o sentido de uma phrase ouvida, nem se quer entende uma local, quando por acaso lhe cae um jornal de Pariz ou Londres sob a mão, ou encontra um dialogo num romance (ibid.).

Como vemos, as ideias dos autores sobre a necessidade do aprendizado prático da língua alinham-se com as já citadas de Goldschmidt e de Nascentes. E na mesma direção, Said Ali, após afirmar que “o conhecimento de varias línguas é um meio, um instrumento com que podemos alargar os horizontes da nossa intelligencia”, assinala que se os métodos modernos diferem entre si em vários pontos, convergem todos para um mesmo fim:

tornar o menino senhor da linguagem atual, empregando-se sobretudo o processo prático e reduzindo-se, ou mesmo eliminando, tanto quanto possível, as longas e enfadonhas regras com que outrora se torturavam e se extenuavam com resultados relativamente insignificantes, quando não era negativo, os cérebros dos jovens estudantes (p. 5, grifos nossos).

O autor destaca que o que a pedagogia moderna não tolera "é que se inicie o estudo de uma língua pelo systema exhaustivo”, especialmente, diz, sendo os destinatários crianças que ainda não têm uma preparação geral indispensável para compreender obras dessa natureza. Ou seja, não se nega a teoria, nem as regras que configuram a gramática, mas ela é questionada quando tomada como ponto de partida. Nesse sentido, vejamos ainda outras intervenções dos autores. Como apresentamos acima, Goldschmidt era a favor de um ensino prático, fazendo referência, para apoiar essa proposta, às dificuldades que encontram sempre para se comunicarem os que gastaram a vida inteira no estudo teórico de uma língua. Na mesma direção, Nascentes diz:

O processo clássico de temas e versões, traduções, regras de gramática, etc., não habilita o aluno a compreender nem a falar a língua estrangeira; habituao a lê-la, a traduzir e a verter. Quando, porém, ele ouve uma conversação, mal percebe uma ou outra palavra e, ao tentar falar, tem as hesitações de quem precisa recordar-se do significado das palavras e das mil e uma regrinhas de gramática (1934, p. 116).

\footnotetext{
${ }^{63}$ Naqueles anos, de modo geral, cada professor produzia sua própria gramática. Não havia circulação de materiais importados, fato que criava a necessidade de uma produção nacional. Outro fator interessante dessa produção nacional é, justamente, o reconhecimento de certas particularidades quando um aluno brasileiro estuda uma língua estrangeira (seja alemão, francês ou espanhol, como estamos analisando). Esse reconhecimento tinha o contraste e a comparação entre as línguas como ferramenta fundamental, reforçando a produção de materiais em português que, segundo os autores, seriam mais proveitosos.
} 
Com relação a um estudo mais teórico, Goldschmidt assinala que não condena o estudo da gramática, ao contrário, afirma que deve ser estudada com rigor, desde que o seu estudo não se torne fastidioso e o estudante esteja preparado para compreendê-la com facilidade.

Ao que parece, o decreto de 1899 sobre o ensino prático tinha tido seus efeitos no Colégio, instaurando essa proposta metodológica nas diversas línguas - ou pelo menos na projeção dessa proposta nos paratextos - e sentando as bases de mudanças posteriores. Pensamos que esse decreto pode ter sido inspirador de outro posterior, de 1931 (como parte da Reforma Francisco Campos), bastante conhecido e citado na literatura sobre o ensino de línguas estrangeiras, que integra as reformas de ensino do governo de Getúlio Vargas, dentre as quais está a que legisla sobre a necessidade de utilizar o “método direto” nas aulas de línguas estrangeiras ${ }^{64}$.

Como deixam transparecer os recortes selecionados, nas intenções anunciadas havia uma tentativa de deslocar o estudo meramente gramatical. Essa nova proposta de ensino prático vinha estreitamente relacionada a outra questão importante, que parece estar bem delineada no "Curso Graduado de língua franceza” (Monat, Ruch, 1901) e que diz respeito ao lugar do professor no processo proposto. Na Introdução, se projeta a imagem de um professor cuja presença é importante para o processo de ensino/aprendizagem da língua e para o funcionamento do método. Além disso, se projeta a imagem de um professor autônomo e conhecedor da língua tanto prática quanto teoricamente. Sem o mestre, afirmam Monat e Ruch (1901), o método dificilmente seria útil. Sem mestre, insistem, "seria impossível aprender a pronúncia” e se perguntam: “como formular as regras?” “[como] representar em portuguez as variantes do "a” francez, do “e” mudo?” e concluem que "só se aprende a pronunciar ouvindo pronunciar” (ibid., p. iv e v). No método, por tanto, o professor era totalmente necessário ${ }^{65}$.

Também na obra de Nascentes pareceria haver a projeção de um professor autônomo. No último parágrafo da pequena seção acrescentada na edição de 1934 - O ensino prático do hespanhol - afirma-se que "para evitar aos professores a monotonia de repetir sempre as mesmas frases" são apresentados "quase sempre apenas os

\footnotetext{
${ }^{64}$ A reforma de 1931 introduziu mudanças não apenas quanto aos conteúdos, mas principalmente, quanto à metodologia de ensino das línguas estrangeiras, dando instruções metodológicas para o uso do método direto, ou seja, o ensino da língua através da própria língua (Leffa, 1999).

${ }^{65}$ Nesse texto introdutório de um livro de francês de começo do século XX, vemos projetada a imagem de um professor que, aparentemente, teria mais autonomia e preparo que o professor antecipado pelos livros produzidos atualmente, para quem se elabora um volume específico com as indicações de tudo o que ele deve fazer nas aulas e no uso dos materiais.
} 
materiais de cada lição, grifando as palavras que diferem muito das portuguesas” (Nascentes, 1934, p. 117). Ou seja, esperava-se do professor que imaginasse formas possíveis para abordar os materiais.

A terceira regularidade detectada refere-se a uma tradição de ensino que tem, na comparação das línguas, a base da metodologia de trabalho. Os diferentes livros analisados nesta seção se inscrevem numa tradição pedagógica escolar e numa tradição de ensino de línguas estrangeiras que propõe a comparação da língua ensinada com as línguas conhecidas (Sánchez, 1992) ${ }^{66}$. Um dos aspectos da comparação aponta a pensarmos as representações das línguas que estão sendo comparadas. No "Curso Graduado de língua franceza”, Monat e Rusch (1901, p. vi) afirmam que “o Methodo procurou fazer o estudo parallelo entre o portuguez, que fallamos no Brasil, com todos os seus vícios perdoáveis, e o francez que se fala e escreve em França, estabelecendo confrontos”. Essa afirmação, além de oferecer pistas sobre como são projetadas as línguas em jogo, parece coerente com uma posição que se opõe à adoção de uma norma central e que, como apresentaremos ainda nesta seção, valoriza a língua em uso ${ }^{67}$.

No caso da Gramática de Nascentes, a comparação é um elemento estrutural da obra: o autor se refere às semelhanças entre o espanhol e o português devido à mesma origem latina - semelhanças que o autor apresenta como evidências que não se discutem (“como toda a gente sabe”, “o espanhol é parecidíssimo como o português” (1934, p. 4). “Quem conhece o português”, continua, “com facilidade lê e compreende o espanhol, sentirá, é verdade, algumas deficiências”68) - e, paradoxalmente (como ele mesmo afirma) se refere a essas semelhanças como à maior dificuldade:

A extrema semelhança das duas línguas, entretanto (parece até um paradoxo) é a maior dificuldade que encontramos, pois quando mal pensamos que uma palavra, uma locação, ou uma forma, se encontra em ambas as línguas, defrontamos profunda diferença (ibid.) ${ }^{69}$.

\footnotetext{
${ }^{66}$ As obras se alinham aos estudos comparados que era a tradição em países que já tinham produzido instrumentos linguísticos para o ensino da língua, como a França e a Alemanha (Sánchez, 1992).

${ }^{67}$ Ainda sobre a caracterização do português presente nesse prólogo, vale a pena observar que uma das funções do estudo de uma língua estrangeira é poder pensar a partir de outra perspectiva a língua própria. Os autores fazem referência ao português falado no Brasil com todos "os seus vícios perdoáveis". Essa afirmativa num livro de francês permite olhar para a língua própria a partir de uma perspectiva pouco presente nos estudos feitos sobre o português como língua nacional, nos quais, de modo geral, o purismo não perdoava "os vícios".

${ }^{68}$ Para compreender o sentido da "facilidade" ao qual Nascentes se refere, é importante situar a relação português/espanhol em meio a um ensino plurilíngue e a uma formação em que os alunos saiam lendo em alemão, inglês e francês. Sem dúvida, havia nesse par linguístico uma "facilidade", que deve ser compreendida nesse contexto específico de formulação.

${ }^{69}$ Esses parágrafos da Introdução da Gramática foram extraídos quase textualmente da Tese de concurso (Nascentes, 1919).
} 
No parágrafo seguinte da Introdução configura-se a justificativa que dá corpo ao que é, ao nosso entender, um dos objetivos do livro:

Daí a necessidade de precisarmos fixar especialmente o que há de diferente nas duas línguas; foi esse o nosso escopo (ibid., itálico nosso).

Como vemos, o autor não se propõe a fazer uma Gramática de espanhol, mas das diferenças entre as duas línguas: “foi esse o nosso escopo”, diz, o que novamente coloca a comparação e o contraste num lugar de destaque. As semelhanças pareceriam ficar omitidas ou em um segundo plano. Fixar esse objetivo produz, evidentemente, certas determinações e restrições no modo de abordar o trabalho com a língua nesse material que será utilizado como apóio para seu aprendizado na escola.

Estabelecer fundamentalmente as diferenças entre as línguas leva implícito um trabalho de contraste que nos ajuda a compreender certas direções que os sentidos tomam no livro. Por exemplo, o fato de que a despeito de reconhecer, por momentos, aspectos da diversidade da língua, quando tem de estabelecer as diferenças entre o português e o espanhol (lembremos que é o objetivo do autor, "seu escopo"), o autor pareceria não poder se aferrar a essa diversidade ou, inclusive, a uma oralidade marginal $^{70}$ (ambas apresentadas de uma ou outra forma, especialmente na Introdução da Gramática). As diferenças entre as duas línguas - eixo que organiza a produção da obra pareceriam apresentar a necessidade de fixar um "núcleo duro”, um núcleo mais estável de comparação que explicitamente o autor define como sendo o da Gramática da RAE de 1917 e que vai atravessando com outros dizeres e vozes.

Na obra de Nascentes, outra questão também diz respeito ao contraste, mas neste caso, ampliando para os efeitos que esse contraste específico (português-espanhol) teria no método proposto e no modo de olhar o trabalho. Embora não esteja presente na primeira edição da Gramática, como já foi dito, a incorporação a partir de 1928 (2 edição) da curtíssima seção chamada $O$ ensino prático do hespanhol nos leva a uma última reflexão. Após se referir ao processo natural pelo qual deve ser feito o ensino prático de uma língua, o autor menciona a revolução feita pelos métodos Berlitz, Paillardan, Gouin, Thora Goldschmidt no ensino das línguas vivas. Nessa primeira colocação aborda as línguas vivas de forma ampla e geral e, a continuação, ao pensar no ensino de espanhol, lamenta serem outros os resultados:

\footnotetext{
${ }^{70}$ Língua falada "pelos judeus espanhóis expulsos da patria no século XV”, na África "pelos judeus marroquinos e nos presídios e possessões espanholas", diz Nascentes (1934, p. 3).
} 
Pena é que o método Berlitz, que tão bons resultados dá no ensino do francês, do inglês e do alemão, não dê os mesmos resultados quanto ao espanhol (Nascentes, 1934, p. 116).

E justifica a afirmação feita da seguinte forma

para um inglês ou para um norteamericano, o espanhol é uma língua muito diferente; por conseguinte, justifica-se a distribuição das lições.

Com o português não se dá a mesma coisa: não há necessidade de gastar uma lição para ensinar as dimensões e as cores, por exemplo, pois o vocabulário é por demais semelhante para que se empregue tanto tempo em ensiná-lo (ibid.).

Segundo Nascentes, a especificidade desse par linguístico, a proximidade e o estreito parentesco entre ambas as línguas tinha que ser levado em conta na hora de elaborar um curso. Diz o autor:

Daí [de toda a explicação feita anteriormente], a necessidade de um curso prático que leve em conta o estreito parentesco entre o espanhol e o português (ibid.).

A proximidade entre as línguas e a especificidade dessa proximidade não eram um aspecto menor para o autor. Podemos reforçar essa afirmação ao analisarmos a determinação presente no título (Gramática da língua espanhola para uso dos brasileiros): não estamos diante de uma Gramática passível de ser usada por qualquer aluno (caso o título fosse apenas Gramática da língua espanhola), mas estamos diante de uma Gramática para uso dos brasileiros. Como vemos, atender a especificidade do par linguístico e do aluno exigia um tratamento também específico. Parece interessante pensar que nas primeiras décadas do século XX isso era uma preocupação para o autor e um eixo organizador no processo de produção da obra ${ }^{71}$.

O problema da proximidade (não só linguística, mas também sócio-histórica) será, a partir da virada do século XX para o XXI, uma problemática que estará presente em diversas reflexões feitas sobre o espanhol em Brasil ${ }^{72}$. Porém, se por um lado, isso se torna um núcleo na produção de conhecimento no Brasil - estamos pensando especialmente nos trabalhos de González (1994), Serrani (1994), Kulikowski e

\footnotetext{
${ }^{71}$ Isso abre um espaço interessante de reflexão, especialmente quando se pensa numa historia mais recente e, mais especificamente, nos livros espanhóis que tomaram conta do mercado editorial a partir dos anos 1990, atendendo aproximadamente 85\% da demanda total (Sokolowicz, 2014). Essas produções pensadas para o âmbito europeu, evidentemente, não estavam preocupadas com o par linguístico espanhol-português, nem sequer na possibilidade de contemplar alunos espanhóis e portugueses. A partir de 2001, esses livros espanhóis chegaram ao Brasil com a marca do Quadro Comum de Referência Europeu estampado nas capas, uma marca que funcionava (e funciona) como selo de qualidade. Em análises anteriores (Sokolowicz 2014, 2018) apresentamos as contradições que surgem quando esse Quadro de Referência, pensado para outro espaço geopolítico de enunciação, é "transportado" ao Brasil, sem contemplar as "transferências” (Orlandi, 1993) necessárias ou as adequações e discussões que a migração de conceitos requer (Arnoux, Bein, 2015). Como afirmamos anteriormente com base em Bourdieu e Waqant (2002), um gesto de imperialismo cultural que foi sendo naturalizado (Sokolowicz, 2014).

${ }^{72}$ Retomaremos essa questão no capítulo 4 da tese.
} 
González (1999), Celada (2002), Fanjul (2002, 2009, 2017) -, por outro, para uma grande produção do mercado editorial, especialmente as produções espanholas que chegaram de forma massiva a partir dos anos 1990, esse aspecto da proximidade pareceria não fazer (e não ter feito) nenhuma diferença ${ }^{73}$. Para Nascentes e, como apresentaremos no capítulo 4, também para Becker, a proximidade linguística dava características próprias e específicas ao trabalho com esse par linguístico.

Até aqui abordamos três questões que nas análises configuraram regularidades presentes nos diversos livros. Uma primeira se refere à necessidade sentida pelos professores/autores de terem disponíveis obras em português. Uma segunda regularidade diz respeito ao ensino prático das línguas e ao lugar ocupado pelas regras gramaticais e, em estreita relação com isso, à projeção de um professor autônomo. A última regularidade se relaciona com o objetivo de estabelecer o contraste e a comparação entre as línguas e, no caso específico da Gramática de Nascentes, tentamos mostrar como o "estreito parentesco" entre o português e o espanhol (segundo palavras do autor) e o fato de ser dirigida a um aluno determinado (o brasileiro e, mais especificamente, um brasileiro com formação plurilíngue) configura um elemento chave no processo de produção da obra.

Se essas regularidades parecem importantes para compreendermos alguns aspectos sobre o modo de abordar o ensino plurilíngue no começo do século XX no Colégio Pedro II e de entender a Gramática de Nascentes nessa conjuntura histórica, social e educativa, também parece importante abordar um último aspecto, presente no livro de francês de Monat e Ruch (1901): a oposição a uma norma central. Essa oposição nos chamou especialmente a atenção pelo seu tom inovador e contestatório a respeito de uma tradição. No começo da Introdução, os autores se perguntam "se seria possível conservar-se a língua nos moldes estritos que tinha quando foi confiada à Academia Franceza, fundada para velar pela pureza do legado que lhe era entregue?” (ibid., p. v). Em diversos parágrafos os argumentos apresentados vão dando respostas a essa indagação inicial: “a língua é feita pelo povo e para o povo. Só elle cria e impõe” (ibid.), afirmam, no que nos parece uma posição anti-purista. Vale a pena recuperar um trecho mais longo dessa mesma Introdução, no qual Monat e Ruch se referem aos barbarismos para precisar os argumentos de oposição à Academia:

\footnotetext{
${ }^{73}$ Para uma melhor compreensão das afirmações, ver Sokolowicz $(2014,2018)$.
} 
Osmose é para ella [a Academia] um barbarismo que nem Littrê ${ }^{74}$ registra: mas os chimicos, os physicos, os agricultores, os médicos continuão a se servir do termo; presidentiel é um adjectivo que ainda não mereceu ser reconhecido, mas os políticos fallão todos os dias em regime presidentiel, sem embargo de saberem, ou não, que o adjectivo é um barbarismo; os literatos servem-se de romantisme, outro barbarismo; ha pouco foi criticado um concurrente por se ter servido n'uma prova do substantivo ressassement: Larousse o emprega e com elle todos os grammaticos. Mas a Academia não o registrou ainda (p. vi).

A opção pela língua em uso é, no recorte, uma evidência, reforçada pela afirmação explícita dos autores de que o Methodo aceita e não hesita diante do "que é de uso corrente”. E para deixar isso mais claro, a modo de exemplo apresenta-se uma lista de mais de vinte "barbarismos” e “mil outros” que, segundo os autores,

não tiveram ainda ingresso no diccionario da Academia, mas que são hoje indispensáveis, e todos os dias são pronunciados por homens de todas as classes sociaes - sábios e ignorantes - mathematicos e industriaes, militares, etc. (...) Eis ahi por que o Methodo frequentemente desobedece à autoridade da Academia (p. vi e vii).

Os autores, ao afirmar que o Methodo “desobedece” a autoridade da Academia justificam ter escolhido o vocabulário no meio próximo, "nas necessidades de todos os dias”, necessidades que atravessariam as diferentes classes sociais. Afirmam ainda que as frases do livro destoam daquilo a que se estava acostumado à época: “em vez dos exemplos clássicos de assumptos nobres, prefere elle ensinar a linguagem de todos os dias com o seu vocabulario trivial, chato, realista” (ibid., p. vii). Concluem a Introdução afirmando, a modo de confissão, que o método “é modesto na forma; no fundo, porém é um livro de reação, revolucionário (...)” (ibid.).

O tom contestatório a essa norma central que representava uma tendência purista no francês apresenta marcas da polêmica entre diversas posições teóricas com relação às línguas. Uma polêmica que, de modo geral, é inerente à formação dos Estados Nacionais e a sua unificação política e que, nas primeiras décadas do século XX, não só está presente num livro que circulou no Colégio Pedro II para o ensino de francês a alunos da elite brasileira, mas que fundamentalmente, está presente nos debates e disputas sobre a língua do/no Brasil que abordaremos no próximo capítulo.

Essas disputas linguísticas dos primeiros anos do século XX são fundamentais, já que fazem parte do ambiente em que Nascentes se forma como gramático, filólogo e lexicógrafo e têm efeitos não só na estabilização de uma norma na Gramática, mas,

\footnotetext{
${ }^{74}$ Nome do filósofo e lexicógrafo francês, autor do Dictionnaire de la langue française, mais conhecido como o Littrê.
} 
fundamentalmente, nos vaivens e oscilações entre essa norma central que o autor tenta estabilizar e aspectos da diversidade da língua apresentados de forma mais periférica.

A posição tomada na apresentação do livro de francês nos mostra que a opção pela língua em uso e por uma oposição direta à Academia era possível para ensinar francês no Colégio Pedro II no começo do século XX. Não foi essa a posição assumida por Nascentes, embora, como apresentaremos no próximo capítulo, fosse um filólogo, lexicógrafo e gramático que tinha presente a diversidade da língua. Quais podem ter sido as variáveis nas opções feitas pelo autor? Quais eram, nesse momento histórico, as disputas linguísticas nas jovens repúblicas emancipadas da Espanha e quais eram os instrumentos linguísticos disponíveis que funcionaram como fontes de consulta para a elaboração dessa Gramática escolar específica. Entendemos que há aí uma chave para uma possível compreensão das diferenças operadas entre o livro de francês e a Gramática de Nascentes e para compreendermos de forma mais aprofundada a direção que as questões linguísticas tomam nesse instrumento linguístico ${ }^{75}$.

\subsection{As fontes e a “unidade” da língua}

Se o livro de francês parece se apoiar de forma explícita num dos lados da polêmica: o da língua em uso, o da variedade, o do vocabulário de todos os dias, o do léxico indispensável que ainda não teve ingresso no Dicionário da Academia Francesa dentre outras das expressões dos autores -, o livro de Nascentes, por sua vez, apóia-se no dispositivo normativo da Gramática da RAE de 1917, que é atravessada, em diversos momentos, por uma tímida referência à diversidade da língua. Os instrumentos linguísticos que já tinham sido produzidos e que Nascentes utilizou como fontes para a elaboração da obra são fundamentais para compreendermos o seu processo de produção. Claramente há uma hierarquia no agenciamento que autor faz delas, numa expressiva adesão - anunciada já na Introdução - à “autoridade soberana da Academia” e corroborada ao longo da obra, inclusive por uma questão quantitativa de frequência de citações. No entanto, cabe perguntar: quem são esses autores, ou melhor, que posições representavam com relação à língua? E, a partir daí, qual poderia ter sido a margem de

\footnotetext{
75 As questões apresentadas no próximo capítulo terão também sua continuação (ampliando e aprofundando explicações) no último capítulo da tese, ao analisarmos as reformulações do Manual de espanhol de Idel Becker.
} 
manobra do autor da Gramática de espanhol no tratamento dado à língua e no modo como vai se vinculando ao dispositivo normativo da Gramática da RAE?

As interrogações colocadas nos obrigam a indagar no horizonte de discursos possíveis do campo dos estudos gramaticais da época e, especialmente, os autores e as obras fontes. Arnoux (2008) explica que esse procedimento é necessário, não só porque desse horizonte de discursos extrai cada obra o universo de objetos e as modalidades de exposição, mas também, porque é o espaço a partir do qual se define a obra e com o qual dialoga (ibid. p. 205-206). Embora Nascentes afirme que "em matéria de ortografia, prosódia, morfologia, purismo de linguagem, vernaculidade, a autoridade soberana da Academia [Espanhola] é obedecida sem discrepância” (Nascentes, 1934, p. 4), expondo assim uma ideologia vinculada a essa instituição e seus instrumentos normativos, ao longo da obra vão sendo citadas outras vozes que, mesmo que timidamente, mostram algum aspecto da diversidade da língua e de lugares de controvérsia.

Além da Gramática da RAE, os autores mais citados são Menéndez Pidal, Bello, Salvá, Toro y Gómez e, com muita menos frequência Velasco, Diez, Rufino Cuervo, dentre outros. Para além dos parâmetros dados pela Gramática normativa da RAE, o livro está atravessado pelo lugar científico que assume a perspectiva do linguista. Estão presentes, por um lado, as referências ao filólogo espanhol Menéndez Pidal, especialmente quando Nascentes se refere à historia da língua e, por outro, as menções ao “ilustre” Bello (assim nomeado por Nascentes). Com esse último autor, venezuelano, e com Rufino Cuervo, colombiano, abre-se um espaço para a produção científica americana, embora nela não se propusesse uma ruptura com a Academia Espanhola, defendendo, como ela, a unidade da língua. Asencio (2004) assinala diversos autores dentre eles Arnoux (1999) ${ }^{76}$, Niño-Murcia (1997) ${ }^{77}$, Rama (1982) ${ }^{78}$ - que identificaram na obra de Bello o interesse por preservar a unidade idiomática na América hispânica.

Aqui há um ponto chave - que iremos aprofundando ao longo dos capítulos -, para compreendermos não só o processo de produção da Gramática de Nascentes, mas, de forma mais ampla, a produção de gramáticas e manuais que acontece ao longo do século XX e especialmente o modo como esses instrumentos se vinculam a um dispositivo normativo. Isso nos leva a perguntar: Quais eram as disputas ao interior das

\footnotetext{
${ }^{76}$ Arnoux, Elvira Narvaja de. El discurso normativo en los textos gramaticales de Andrés Bello. Prácticas y representaciones del lenguaje ed. por E. Arnoux e R. Bein, 37-62. Buenos Aires: Eudeba, 1999.

${ }_{77}$ Niño-Murcia, Mercedes. Ideología lingüística hispanoamericana en el siglo XIX: Chile (1840-1880). Hispanic Linguistics 9.1. 100-142, 1997.

${ }^{78}$ Rama, Carlos. Historia de las relaciones culturales en tre España y América Latina. Sigla XIX. México: FCE, 1982
} 
políticas linguísticas e as tensões entre a Espanha e os países emancipados no século XIX? E ainda, quais eram os instrumentos linguísticos elaborados até esse momento no processo de gramatização da língua? Embora com diferenças, todos eles defendiam a manutenção da unidade linguística, apesar de alguns deles reconhecerem programaticamente as variedades dialetais cultas.

Para começar a abordar essas questões trazemos as reflexões de Fanjul (2011), quem analisa os "deslocamentos na vida política da língua espanhola”79 adentrando no que reconhece como uma era policêntrica e um longo século (desde os últimos anos do século XIX) atravessado por uma política linguística pan-hispânica. Um questionamento que levanta no texto é "por que a separação das ex-colônias [especialmente na segunda metade do século XIX] não deu lugar a algum tipo de entidade glotopolítica enunciada como outra em relação à Espanha, uma “outra língua com nome” (Fanjul, 2011, p. 309). Existiria a possibilidade, diz Fanjul, de que um Estado ou conjunto de Estados “enuncie sua variedade de prestígio como uma nova língua”. Isso, evidentemente, poria em xeque a unidade. Nesse sentido, faz referência ao projeto de Reforma Ortográfica produzido no Chile na década de 1840, talvez como o mais significativo nessa direção ${ }^{80}$. Porém, chama a atenção para o que entende que é uma atitude paradoxal: "Os dirigentes mais comprometidos com o desenvolvimento cultural autônomo das novas nações, e ainda com uma perspectiva de unidade continental”, diz Fanjul (p. 310), "mostraram preferência pela manutenção da unidade linguística, embora isso significasse uma mesma identidade linguística com a Espanha”. Foi essa, segundo o autor (ibid. p. 311) a política que predominou. Na mesma direção, embora com algumas diferenças interpretativas, Asencio auxilia na compreensão da “atitude paradoxal” - mencionada por Fanjul - de alguns dos dirigentes hispanoamericanos mais comprometidos. A autora assinala que os processos de independência política das colônias americanas determinaram nas últimas décadas do século XIX uma situação sociolinguística de conflito. Ela assim o expressa:

\footnotetext{
${ }^{79}$ É esse o subtítulo do capítulo: "Policêntrico" e "Pan-hispânico". Deslocamentos na vida política da língua espanhola (2011, p. 299-331).

${ }^{80}$ Esse projeto tinha sido proposto pelo argentino Domingo F. Sarmiento e apoiado inicialmente pelo venezuelano Andrés Bello, naquele tempo reitor da universidade nacional chilena (Fanjul, 2011). Segundo Asencio (2004, p. 222), a Reforma era "una dura crítica a los sistemas ortográficos basados en criterios etimologizantes (como el empleado por la RAE entonces)". A autora afirma que a proposta, basada em un criterio fonético, "consiste en algunas sustituciones ortográficas destinadas a facilitar el aprendizaje de la lengua” (ibid.).
} 
los países recién constituidos son independientes en el plano político, pero siguen manteniendo el carácter de "colonias" en los planos lingüísticos y cultural (Asencio, 2004, p. 219).

As afirmações dos dois autores nos permitem fazer uma primeira observação: se os dirigentes hispano-americanos que pregavam a independência política - e, para Fanjul (2011), também o desenvolvimento cultural autônomo das novas nações apresentavam, ao mesmo tempo, uma preferência pela manutenção de uma unidade linguística com a Espanha, qual era a possibilidade de Nascentes fazer uma obra que se afastasse dessa unidade e dessa preponderância dada a uma normativa central presente na Gramática produzida por ele no Brasil? Como pareceria ter sido a opção anunciada pelos autores do livro de francês que consideraram certa diversidade, fazendo referência ao que hoje chamaríamos aspectos dialetais, socioletais e de registro.

Para dar sustento e compreender os fundamentos dessa política de preservação da unidade, Fanjul analisa o prólogo da gramática de Andrés Bello, de 1847, buscando mostrar a preocupação do venezuelano com “a possível balcanização linguística”:

\footnotetext{
Mas o maior mal de todos, aquele que, se não for eliminado, vai nos privar das inapreciáveis vantagens de uma língua comum, é a torrente de neologismos de construção, que inunda e turva muito do que se escreve na América e, alterando a estrutura do idioma, tende a transformá-lo em uma multiplicidade de dialetos irregulares, licenciosos, bárbaros, embriões de idiomas futuros, que, durante uma longa elaboração, reproduziriam na América o que foi a Europa no tenebroso período da corrupção do latim (Bello 1984, p. 33, apud Fanjul 2011, p. 311).
}

Embora seja clara a preocupação de Bello com a possível transformação do idioma numa “multiplicidade de dialetos”, Fanjul afirma que essa atitude estava longe de qualquer subordinação à norma produzida na Espanha e um novo recorte da Gramática de Bello apresentado pelo autor permite compreender a "legitimação de uma padronização policêntrica apoiada nos usos de prestígio local” (ibid., p. 312).

O estudioso reconhece nesse autor uma preocupação representativa de uma tendência do campo intelectual hispano-americano que "alça a unidade como força perante a possibilidade de dispersão ou de influências `bárbaras’” (ibid. p. 312). Se a unidade da língua era alçada, mesmo pelo emergente campo intelectual hispanoamericano, e pela Gramática de Bello (que é uma das fontes americanas para Nascentes na produção da sua obra), qual teria sido, insistimos, a possibilidade de manobra - como afirmamos acima - para não aderir a essa unidade ou para que o livro não estivesse regido pela "soberana autoridade” da Academia, reforçando a norma central que era 
imposta à língua? Especialmente se pensarmos nas condições de produção da Gramática que Nascentes elaborara para ensinar essa língua como estrangeira.

Ao analisarmos essa obra, no próximo capítulo, buscaremos rastrear as marcas e os efeitos dessas reflexões e debates do campo intelectual. Em que medida é possível rastrear a ideia historicamente construída de “unidade do espanhol” na Gramática produzida para o ensino de espanhol no Colégio Pedro II e, em que medida, vemos emergir certos dizeres que buscam apresentar aspectos da diversidade da língua.

Neste primeiro capítulo buscamos compreender aspectos das condições sóciohistóricas de produção dos acontecimentos inaugurais abordados, a partir de três escalas particulares de observação que nos permitiram pensar possíveis redes de determinações do discurso: as relações internacionais, o autor da obra e a cidade e sociedade na qual se insere, e o institucional. A incorporação do espanhol no Colégio Pedro II, o primeiro concurso e a produção da primeira Gramática de espanhol para uso dos brasileiros (Nascentes, 1920), vistos e estudados a partir do entrecruzamento de escalas diferentes de observação, foi esse o itinerário do capítulo. Esse movimento intensificou a densidade dos objetos estudados, possibilitando uma interpretação que levasse em conta sua complexidade. Um capítulo que encontra continuação no próximo, no qual abordaremos a formação do autor em meio aos debates e disputas de época, analisando, por um lado, as marcas que funcionam como indícios de suas ideias e concepções linguísticas e, por outro, o modo como essas ideias se materializam na Gramática de espanhol produzida nos anos 1920. 


\section{CAPÍTULO 2}

Debates e disputas no campo linguístico e os efeitos na produção da Gramática 
As independências políticas e a constituição dos novos Estados Nacionais na América Latina instalaram nos debates, já desde as décadas centrais do século XIX, a questão linguística. As disputas em torno à língua, que haviam começado durante o período colonial, foram mais acirradas no cerne dos debates políticos nas jovens nações após os processos de independência: era o momento de construção e delimitação das línguas nacionais. Arnoux e Del Valle (2015, p. 146) examinam como as antigas metrópoles - que continuam atuando sob uma lógica colonial - e as antigas colônias, lutam, naqueles anos, pela gestão de uma língua compartilhada. Os autores assinalam que essa gestão ocorre por meio de ações que revelam a tensão entre o colonialismo de uns e a proteção da soberania nacional de outros. Assim, os confrontos e conflitos entre as tendências puristas que queriam impor a língua da metrópole, fosse ela Portugal ou Espanha, propondo uma continuidade e os que queriam um distanciamento ou, até, uma separação definitiva, deixaram suas marcas nos discursos em circulação e na produção de diversos instrumentos linguísticos, dentre eles, as gramáticas que começavam a ser elaboradas ${ }^{81}$.

No Brasil, as décadas iniciais do século XX estão marcadas pelas disputas linguísticas entre os que tomavam uma tradição portuguesa (homogênea, culta e estandarizada) como modelo e os que propunham uma ruptura, defendendo as especificidades da língua no Brasil (diversificada nas suas muitas falas regionais) (Guimarães, 2004) ${ }^{82}$. Duas matrizes de sentido que regulam o que pode e deve ser dito. Partindo da hipótese que esses discursos científicos de época, que se vinculam a

\footnotetext{
${ }^{81}$ As primeiras décadas do século XX apresentam marcas da polêmica entre diversas posições teóricas com relação às línguas. Uma polêmica que, de modo geral, parece inerente à formação dos Estados nacionais e à unificação política dos mesmos, a partir da segunda metade do século XIX. Alguns trabalhos que apresentam considerações sobre o mundo lusófono são: Orlandi ([1990] 2008), Guimarães (2004), Mattos, Medeiros (2013), para o mundo hispânico: Glozman e Lauria (2012), Ennis (2008, 2013), Arnoux (2014). Diego Bentivegna (2013) no Estudio Preliminar à obra de Gramsci por ele traduzida (Escritos sobre el lenguaje) apresenta essas tensões nos anos de unificação política da Itália: de um lado, uma tradição positivista e biologizante e, de outro, uma que centrava a mudança linguística a partir de um olhar histórico-cultural.

${ }^{82}$ A discussão proposta por Guimarães trabalha sobre as disputas desses dois grupos. Mariani (2011) retoma essas duas matrizes de sentido, afirmando que para uns "no solo brasileiro há uma variante brasileira da língua portuguesa e essa variante tem normas, um modo próprio de usar a língua, que divergem do português padrão" (ibid., p. 237); para outros, porém, "a língua falada no Brasil é herdeira do gênio e da gramática da língua portuguesa” (ibid.). A autora acrescenta que entre essas duas matrizes haveria uma terceira: "os que defendem os clássicos, mas aceitam, em parte, o modo brasileiro de escrita e fala” (ibid. p. 237-238).
} 
formações discursivas antagônicas formam parte da rede complexa de condições sóciohistóricas de produção e atravessam o discurso gramatical, o objetivo deste capítulo é abordar esse aspecto específico. Trata-se de compreender os efeitos desses debates linguísticos não só na formação de Nascentes como lexicógrafo, filólogo e gramático, mas também nas repercussões dessa formação na configuração da língua projetada na Gramática produzida para o ensino da língua espanhola no Colégio Pedro II.

Para tanto, na primeira parte do capítulo nos interrogamos sobre os discursos científicos de época e analisamos as marcas que funcionam como indicio das posições que o autor vai ocupando (ou assumindo) com relação ao português do Brasil e as que especialistas da área - leitores da sua obra - atribuem a ele. Desse modo buscamos rastrear as ideias linguísticas presentes nas reflexões desse autor que em 1920 lança a primeira gramática de espanhol para o ensino dessa língua no curso secundário. Na segunda parte, vamos nos deter no funcionamento discursivo da Gramática, buscando compreender a dimensão política do processo de estabilização da norma. Se de modo geral, a obra de Nascentes legitima a norma linguística da Gramática da Real Academia Espanhola de 1917 (por meio de um processo que já na Introdução da obra anuncia essa preferência e que recorta e estabiliza determinados saberes, conformando um imaginário sobre a língua), também é verdade que nela a língua é apresentada como um terreno onde também existem controvérsias entre as vozes que conformam as fontes consultadas.

\section{Norma e língua nacional nos anos 1920}

Ao se referir ao português do Brasil, Orlandi (2002) identifica uma "identidade dupla”: uma heterogeneidade linguística constitutiva própria de línguas que passaram por processos de conquista e colonização. Fala-se a mesma língua, mas se fala diferente, diz a autora, referindo-se a um "fundo falso, em que o mesmo abriga, no entanto, um outro, um diferente histórico que o constitui ainda que na aparência do mesmo” (ibid., p. 23). A história da colonização e da formação dos países marca as línguas de forma diferente e, desse modo, embora recobertas pela aparência do mesmo, produzem discursos distintos e significam diferentemente (ibid.) ${ }^{83}$, aspectos todos que marcam a produção de instrumentos

\footnotetext{
${ }^{83}$ A homogeneização que produz o efeito do mesmo é produto do processo de colonização pelo qual passaram tanto o português do Brasil como o espanhol da América, nesse sentido (e em outros) línguas próximas. As palavras de Borges em El idioma de los argentinos (1928), embora se referindo ao
} 
linguísticos. Essa mesma língua que significa diferentemente - o mesmo que abriga um outro - ocupava o centro das disputas linguísticas desses anos.

Com o objetivo de observar mais especificamente os estudos do português do Brasil a partir do final do século XIX, Guimarães (2004) propõe uma periodização que divide o processo de gramatização brasileira do português em quatro períodos, levando em consideração fatos de ordem política e institucional. Nesse trabalho, identifica a etapa que vai da segunda metade do século XIX até os anos 1930 como o segundo período da gramatização ${ }^{84}$. Conforme o autor, nesse período iniciaram-se os estudos do português do Brasil com a publicação de gramáticas que defendiam especificidades para a língua brasileira. O pesquisador afirma que uma das características do conjunto de estudos sobre o português no Brasil nesse momento "é o trabalho de demonstrar que o português que aqui se falava e escrevia era diferente do português de Portugal” (ibid., p. 24), fato que abre, segundo o próprio Guimarães, um novo processo nos estudos de língua. Essas novas posições nos estudos da linguagem disputavam com outras que defendiam a unidade da língua em Portugal e no Brasil (ibid.).

Mariani (2011, p. 246-247), retomando a periodização de Guimarães, afirma que “é um período de publicações de importantes gramáticas e dicionários caracterizados pela inclusão do determinante "brasileiro” em alguns títulos” e dá o exemplo do Dicionário brasileiro da língua portuguesa, de Antônio Joaquim de Macedo Soares.

Esses trabalhos convivem com outros que assumem posições puristas (mais dominantes naqueles anos), produzindo-se tensões que dão continuidade a outras

espanhol, iluminam a disputa de sentidos entre a ex metrópole e as ex colônias: "Muchos, con intención de desconfianza interrogarán: ¿Qué zanja insuperable hay entre el español de los españoles y el de nuestra conversación argentina? Yo les respondo que ninguna, venturosamente para la entendibilidad general de nuestro decir. Un matiz de diferenciación sí lo hay: matiz que es lo bastante discreto para no entorpecer la circulación total del idioma y lo bastante nítido para que en él oigamos la patria. No pienso aquí en los algunos miles de palabras privativas que intercalamos y que los peninsulares no entienden. Pienso en el ambiente distinto de nuestra voz, en la valoración irónica o cariñosa que damos a determinadas palabras, en su temperatura no igual. No hemos variado el sentido intrínseco de las palabras, pero sí su connotación. Esa divergencia, nula en la prosa argumentativa o en la didáctica, es grande en lo que mira a las emociones. Nuestra discusión será hispana, pero nuestro verso, nuestro humorismo ya son de aquí. Lo emotivo -desolador o alegrador- es asunto de ellas y lo rige la atmósfera de las palabras, no su significado. La palabra súbdito es decente en España y denigrativa en América. La palabra envidiado es formulación de elogio en España (su envidiado tesoro de voces pintorescas, felices y expresivas, dice la Gramática oficial de los españoles), y aquí, jactarse de la envidia de los demás nos parece ruin” (apud Glozman, Lauría, 2012, p. 54-57).

${ }^{84}$ Nessa periodização, Guimarães coincide com Nascentes a respeito da obra que inauguraria o segundo período (Grammatica Portugueza, de Júlio Ribeiro, em 1881), embora as periodizações difiram. Segundo Cunha (2003), Nascentes "foi quem primeiro esboçou a periodização da história da filologia portuguesa no Brasil em dois artigos enfeixados nos Estudos Filológicos - "A Filologia Portuguesa no Brasil" e "O Pedro II e a Filologia Portuguesa", contribuições que serviram de base para os que posteriormente escreveram sobre o assunto". Os artigos citados encontram-se em Estudos Filológicos, $1^{\text {a }}$ série. Rio de Janeiro, Civilização Brasileira, 1939. 
anteriores, como a célebre polêmica entre José de Alencar e o escritor português Pinheiro Chagas pelas críticas deste último à linguagem de Alencar em Iracema ${ }^{85}$. De início de século e como marca também do litígio em torno do purismo é a polêmica entre Rui Barbosa e Ernesto Carneiro Ribeiro sobre a redação do Código Civil (Nascentes, 1939) ${ }^{86}$. As tensões surgidas nos debates por questões linguísticas não eram assuntos novos.

Essa segunda fase da gramatização brasileira do português nos interessa porque faz parte do ambiente em que Nascentes se forma e, sendo assim, das condições de produção nas quais surge a Gramática estudada. Como afirmamos acima, os litígios e as disputas acontecem entre os que tomam os modelos portugueses de língua como modelares e os que propõem uma ruptura. Conflitos em torno à língua que, como afirma Lucchesi (2015), fazem parte das disputas ideológicas determinadas pelas contradições sociais. É nesses anos que Nascentes produz a Gramática que estamos estudando e é essa obra - adotada numa instituição modelo de ensino secundário (Dezerto, 2013) - a que inaugura uma tradição: a gramatização brasileira do espanhol, isto é, a produção (no Brasil e por brasileiros) de instrumentos linguísticos para o ensino da língua. Por isso, cabe fazer mais uma série de perguntas: Quais são as filiações teóricas a partir das quais Nascentes significa as línguas? E com relação às duas matrizes de sentido: Que impacto teve no autor da Gramática a memória da tradição positivista (purista) em circulação naquela época, que via a língua do/no Brasil no lugar do erro, da deturpação, do desvio (uma variação doente da língua matriz portuguesa) (Guimarães, 2004; Mattos e Medeiros,

\footnotetext{
${ }^{85}$ Essa polêmica aconteceu em 1870, quando Pinheiro Chagas critica Alencar por ter a "mania de tornar o brasileiro uma língua diferente do velho português por meio de neologismos arrojados e injustificáveis e de insubordinações gramaticais" (apud. Nascentes 2003d, p. 189). Nascentes explica que as insubordinações consistiam "no uso parcimonioso do artigo definido, na omissão do pronome se junto aos verbos reflexivos, na colocação dos pronomes pessoais que servem de complemento ao verbo [...] (ibid.). Lucchesi (2015) também faz referência a essa polêmica. O autor comenta que embora a independência política tenha desencadeado manifestações e movimentos indigenistas que tentaram abordar a língua adequando-a a essa nova realidade cultural, como no caso de José de Alencar, o autor de Iracema foi alvo de críticas provenientes do purismo gramatical: "o enfrentamento da questão da língua no Brasil tem sido crítico desde a formação da nacionalidade” (Lucchesi, 2015, p. 23). O estudioso faz uma observação muito interessante sobre a especificidade da língua: "Mais uma vez, a língua se deslocou dos demais aspectos da cultura; pois, se todos os elementos representativos da brasilidade deviam ser valorizados em detrimento dos símbolos da velha ordem colonial, a linguagem brasileira passou a ser vista como imprópria e corrompida, devendo prevalecer o cânone coimbrão, da antiga metrópole colonial” (ibid., p. 24). A teorização desenvolvida pelo autor, que segue o caminho trilhado por Milroy e Milroy, tenta apreender os conflitos sociais em torno da língua como partes das disputas ideológicas determinadas pelas contradições sociais (ibid., p. 72). Nesse sentido, "a vitória dos puristas na questão da língua no Brasil, ocorrida entre final do século XIX e o início do século XX, expressa a essência do projeto elitista e excludente da classe dominante brasileira, expressão legítima de uma sociedade patriarcal e latifundiária, assentada no trabalho escravo" (ibid., p. 24).

${ }^{86}$ Em A redação do código civil: polêmica linguística, jurídica ou política? Mariani (2011) faz uma análise dessa polêmica.
} 
2013)? Que impacto tiveram as vozes que defendiam um falar brasileiro? E, finalmente, como se manifestam esses sentidos em seus escritos e produções?

Em função dessas indagações, buscamos rastrear em diversos escritos do autor (livros, cartas, artigos etc.), elementos que permitem vislumbrar como vão se configurando posições em meio a essas controvérsias e conflitos de época. Interessam-nos, especialmente, algumas marcas que funcionam como indícios de um sujeito que oscila e transita por esses discursos antagônicos, atravessado pelas tensões que surgem do debate sobre a norma (a unidade em relação à diversidade linguística; a norma padrão em oposição às variedades). Partimos da hipótese que essas oscilações com relação à língua do/no Brasil (uma língua que vai se diferenciando daquela da metrópole) têm ressonância e podem ser rastreadas na Gramática de língua espanhola na qual a forte adesão a uma norma filiada à RAE é atravessada por outras vozes e por uma apresentação (mesmo que tímida) da diversidade linguística. Para tanto, propomos pensar quais efeitos tiveram as tensões entre uma tradição purista e outra que propunha uma ruptura, não só na posição do autor com relação à língua do/no Brasil (produzindo continuidades, rupturas, transformações), mas também com relação ao tratamento dado ao espanhol na elaboração da Gramática.

Diversos escritos nos permitem afirmar que Nascentes estava atento ao que era a ciência aceita na época, a ciência dominante. No entanto, partindo dessa ciência dominante, também observamos que Nascentes vai marcando diferenças, ampliando o olhar e intentando construir um dizer que apresenta marcas dos discursos antagônicos sobre a língua. As análises desenvolvidas adiante buscam dar sustento a essa afirmação.

Surge assim um eixo importante de reflexão para compreendermos as filiações teóricas e gramaticais do autor e, consequentemente, os modos de significar a(s) língua(s). Para abordarmos essas questões, em primeiro lugar (em 1.1. e 1.2.), apresentamos essa problemática rastreando o modo como Nascentes vai construindo uma voz com relação ao português do Brasil. Buscamos compreender quais são suas concepções linguísticas e o imaginário projetado sobre a língua. Nesse sentido, formulamos uma pergunta organizadora a partir de uma questão que preocupava particularmente esse estudioso e sobre a qual manifestou opiniões diversas (Cunha, 2003): qual era o estatuto linguístico do português do Brasil? Tentando nos aproximar a possíveis respostas, mapeamos opiniões de especialistas e dele próprio em diversos escritos e, especialmente, em sequências do livro O linguajar carioca (Nascentes, 1922), uma obra fundamental para os estudos dialetológicos do português no Brasil - que tomam 
forma mais específica nesses anos (Guimarães, 2004, p. 31) - e bastante expressiva para compreendermos as posições e as ideias de Nascentes em matéria linguística.

Em segundo lugar (no item 2), propomos refletir sobre as "ressonâncias” dos vaivens detectados com relação à língua portuguesa do/no Brasil, na obra produzida para o ensino de espanhol no ensino secundário. Ou seja, em que medida essas concepções linguísticas mais amplas podem ser rastreadas na Gramática de espanhol e, ao mesmo tempo, que outras variáveis e particularidades entram em jogo nessa obra específica, uma gramática de uma língua que para ele era estrangeira, ou, como veremos, "singularmente estrangeira”.

\subsection{Nascentes e o estatuto da língua portuguesa do/no Brasil}

Em diversos escritos, produzidos em momentos diferentes de sua carreira e de sua produção científica, Nascentes deixa transparecer como entende a língua - o "Idioma Nacional”, como preferia chamá-la (nem língua portuguesa, nem língua brasileira) ${ }^{87}$. A seguinte frase, referida à diferença na pronúncia da língua em Portugal e no Brasil, parece conter uma síntese do seu pensamento: "O certo é que a diferença entre elas é tão grande que chega a levar à impressão errada de que as línguas são duas” (2003a, p. 392) ${ }^{88}$. Para Nascentes as diferenças eram claras e significativas, no entanto, isso não criava uma situação de ruptura e por isso considerava “errado” pensar “que as línguas [eram] duas”.

Em outra oportunidade, em carta escrita em resposta às críticas de Jorge Guimarães Dupiás ao livro O Linguajar Carioca, Nascentes comenta: "Não sou tão partidário, como a V. Ex.a. pareceu, da separação linguística absoluta entre Portugal e o Brasil” (Nascentes, [1924] 2003c, p. 613) e, imediatamente acrescenta: "acredito que os elementos conservadores, a comunicação constante dos dois países e outras causas concorrerão para se manter uma relativa unidade, o que não exclui a existência de diferenças mais ou menos importantes” (ibid.).

Apesar de reconhecer e assinalar as diferenças, Nascentes entendia que não se podia pensar em línguas diferentes. Assim se expressava sobre o vocabulário no artigo $A$ língua brasileira: “A língua falada e escrita no Brasil é a língua portuguesa com alterações pelo uso de vocábulos exclusivamente nacionais ou regionais que enriqueceram a língua, tornando-a mais opulenta, mas que não bastam para construir língua nova”

${ }^{87}$ O Idioma Nacional é o título de uma série didática produzida por Nascentes, cujo primeiro volume é de 1927.

${ }^{88}$ Publicado inicialmente em: Mélanges de Linguistique et de Littérature Romanes Offerts à Mario Roques, Paris, Librairie Marcel Didier, t. III, MCMLII, pp. 177-83. Na mesma direção, na Introdução de O Idioma Nacional (1927, p. 8) afirma: "uma criança brasileira de quatro anos até distingue logo quando quem fala é um patrício seu ou é um português”. 
(Nascentes, 2003b, p. 312). Nesse mesmo artigo o estudioso comenta o projeto apresentado em 1935 à Câmara Federal do Distrito Federal para que nos livros didáticos, nos programas de ensino e nas denominações das cadeiras de ensino de língua pátria a denominação fosse "Língua Brasileira" ${ }^{89}$. O projeto foi bastante combatido, inclusive na imprensa, aspecto que Nascentes apresenta no seu artigo. Nele também reproduz sua opinião ao respeito publicada no vespertino O Globo em 29 de julho de 1935 em resposta à seguinte pergunta: “E que vem a ser a língua falada no Brasil?”:

\begin{abstract}
Um dialeto muito caracterizado da língua portuguesa e nada mais que um dialeto. Faltam-lhe as características que lhe dêem a categoria de uma língua. $\mathrm{O}$ sistema fonético é o mesmo do português; na pronúncia normal só se nota a ausência do e reduzido. As flexões são idênticas, morfemas de número (o s), de gênero (o a), de grau (íssimo), desinências pessoais e temporais dos verbos não apresentam discrepância. A sintaxe, a não ser o caso da colocação dos pronomes oblíquos, poucas variações apresenta. A diferença de sotaque (notada dentro dos próprios países), é secundária. O abundante vocabulário de origem tupi e africana não atinge o cerne da língua portuguesa [...] (2003b, p. 314). O mesmo motivo que há para se criar uma língua brasileira atualmente, haveria para se criar uma algarvia, uma paulista, uma paraense. Se não se quiser chamar língua portuguesa, denomine-se língua vernácula, idioma nacional, português de América, tudo, menos língua brasileira (ibid. p. 315).
\end{abstract}

Já em 1922, ao escrever O linguajar carioca, aceitara a classificação de dialeto dada por Leite de Vasconcelos ${ }^{90}$ e admitira a existência de quatro subdialetos (Cunha, 2003, p. 157). Em 1935, como mostra o recorte apresentado acima, Nascentes manteve essa posição. No entanto, Cunha (2003, p. 157) assinala que na reedição do livro $O$ Linguajar carioca, em 1953, Nascentes retificaria sua posição e passaria a denominar “falar brasileiro” à forma expressional em seu conjunto.

Essa mudança conceitual também apresenta um estudioso atento às transformações dos conceitos com o passar do tempo, de acordo com o progresso da ciência e da linguagem. Num artigo intitulado Quarenta anos de amizade, o próprio Nascentes conta uma história acontecida com um dos que fora seu companheiro no

\footnotetext{
${ }^{89} \mathrm{O}$ projeto, apresentado pelo vereador Frederico Trotta em 5 de junho de 1935 foi aprovado com algumas alterações e vetado pelo prefeito Dr. Pedro Ernesto em 7 de agosto do mesmo ano (Nascentes, 2003b, p. 309-310). ${ }^{90}$ Nascentes afirma que o linguista e filólogo português Leite de Vasconcelos ataca, de início, a questão de saber se o português do Brasil é dialeto ou não. Vasconcelos afirma que se ele chama dialeto o português de Trás-os-Montes, com mais razão deve dar esse nome ao português do Brasil. Nascentes concorda com o Mestre (como o chama) e afirma: "Nem que ele não chamasse dialeto o português de Trás-os-Montes ou outro qualquer de Portugal continental, desdouro algum haveria em falar-se um dialeto. É uma situação criada pela vida, como foi outra da mesma natureza a de Portugal ter sido romanizado. Não vejo razão para se exacerbarem melindres nacionais” (Nascentes, 2003e, p. 743). Ou seja, Nascentes não via problema em chamar de dialeto a língua falada no Brasil, até pelas explicações dadas anteriormente: a despeito das diferenças, existia para ele uma relativa unidade e as diferenças não criavam a existência de duas línguas, todos eram dialetos. Como tentamos mostrar, essas afirmações vão sendo repetidas ao longo dos anos, mesmo defendendo a necessidade de não submeter o falar diferente do Brasil às formas de Portugal.
} 
Colégio Pedro II, Manuel Bandeira, com quem teve uma relação “que o tempo”, diz o próprio Nascentes, “se encarregou de transformar em amizade até [aquele momento] inquebrantada”. E acrescenta:

Bandeira era dos mais vivos do grupo, dos mais brigões; corrigia qualquer erro que se cometesse. Foi com ele que comecei a tomar cuidado com a colocação dos pronomes à portuguesa. Não lhe agradeço este serviço; criou-me um hábito que hoje me impede de colocar os pronomes à brasileira (2003i, p. 726).

Foi sempre um observador dos modos diferentes do funcionamento linguístico a ambos os lados do Atlântico. Mas se não reconhecia a intensidade que permitiria falar em duas línguas diferentes, também é verdade que seus escritos estão atravessados pela descrição dessas diferenças. Em 1929, Nascentes afirmava que, refletindo sobre a língua que se fala no Brasil, não teve a coragem de chamá-la portuguesa, e foi esse o motivo para intitular a série de livros escrita para a escola O Idioma Nacional.

Poderíamos continuar pinçando manifestações do autor sobre esta questão, já que foram muito numerosas e diversas ao longo de sua reflexão. No entanto, para finalizar este item no qual buscamos ver como vai se posicionando com relação às disputas sobre o português do/no Brasil, focamos alguns aspectos de uma obra fundamental da historia da dialetologia (O Linguajar Carioca, 1922) - contemporânea da Gramática de espanhol -, na qual o autor expõe sua visão com relação à língua nacional e que, já no prólogo, nos permite vislumbrar a compreensão histórica e social que Nascentes tinha sobre ela.

\subsection{O linguajar carioca (1922): ideologia dominante e construção de um dizer próprio}

No livro O linguajar carioca, publicado em 1922 e reeditado em 1953 - com algumas modificações -, Nascentes inova na área de geolinguística propondo um estudo das falas da região (Silva, 2012). Apresentamos sinteticamente a recepção da obra em décadas posteriores, recuperando leituras e leitores que deram ao livro e ao autor um lugar de destaque na dialetologia brasileira. Desde então, os trabalhos do autor foram reconhecidos como um dos pilares dos estudos dialetológicos no Brasil. 


\subsubsection{Leitores e leituras}

No número especial da Revista da Academia de Filologia, em Homenagem a Antenor Nascentes (2014) ${ }^{91}$, Ribeiro (editor da revista) e Bechara apontam o caráter inovador que obra e autor tiveram à época da publicação. Ribeiro afirma que os trabalhos de Nascentes buscaram observar a "variedade da linguagem” que ocorre em todas as línguas, e isso "constituiu um avanço, numa época em que a tradição gramatical era muito comum e muito ainda não se tinham livrado da influência portuguesa” (2014, p. 7). Bechara, ao igual que Ribeiro, ressalta a posição inovadora de Nascentes. Diz o autor: “numa época em que a grande preocupação consistia no purismo gramatical, o livro era como um crime de lesapátria” (2014. p. 26) ${ }^{92}$. Crime esse do qual Nascentes parece ter tido consciência já nessas primeiras décadas do século XX, ao afirmar, logo na primeira página do livro:

\footnotetext{
Conhecemos bem o nosso meio: não ignoramos os remoques que nos hão de trazer os estudos de patologia lingüística que empreendemos.

Paciência. Nosso trabalho não é para a geração actual; daqui a cem anos, os estudiosos encontrarão nele uma fotografia do estado da língua e neste ponto serão mais felizes do que nós que nada encontramos do falar de 1822 (Nascentes, 1922, p. 9, itálico nosso).
}

O autor antecipava-se ao tom ofensivo (“os remoques”) que possíveis contestações ao trabalho poderiam traze-lhe, ofensas que, no entanto, não o amedrontavam. Ao mesmo tempo, projetava seu trabalho para o futuro, para os dias atuais, vaticinando a felicidade dos estudiosos - "daqui a cem anos os estudiosos encontrarão nele uma fotografia do estado da língua e neste ponto serão mais felizes do que nós” - e se lamentava por não ter uma fotografia da língua de cem anos atrás (“que nada encontramos do falar de 1822”). Nesse sentido, vemos um estudioso consciente da construção de conhecimento sobre a língua e da importância histórica desse conhecimento.

Bechara (2014, p. 26) também assinala que o autor tinha sua atenção voltada à "língua materna” e que tais estudos despertaram interesse nos meios científicos estrangeiros, fato que sem dúvida motivou que Meyer-Lübke ${ }^{93}$ pedisse em carta a Nascentes “informações a respeito das alterações sofridas no Brasil pela língua portuguesa”. Esse pedido despertou nele - como conta o próprio Nascentes (1922) - a

\footnotetext{
${ }^{91}$ O número da Revista reúne artigos escritos em diferentes épocas e por diferentes estudiosos.

92 Essa mesma força inovadora é reconhecida nos comentários de Mattoso Câmara Jr. (2014) e Domingues e Henriques (2014) já apresentados no capítulo anterior, na seção "O autor: biografia, filiações teóricas e trajetória intelectual”.

${ }^{93}$ Wilhelm Meyer-Lübke ( Suíça, 1861 / Alemanha, 1936) foi um importante filólogo suíço da escola de Neogramática que estudara com Diez, o grande especialista da romanística européia e que escreveu o Prefácio ao Dicionário Etimológico (1931) de Antenor Nascentes.
} 
ideia de organizar as notas sobre as questões de dialetologia portuguesa no Brasil. Essas notas surgiram das observações atentas do autor: “anotávamos o que de mais importante encontrávamos”, diz no Prefácio de O linguajar Carioca, “quer na fonética, quer na morfologia, quer na sintaxe, quer no léxico” (ibid. p. 9).

O livro está constituído por um Prefácio, uma espécie de introdução chamada $\mathrm{O}$ dialeto brasileiro e quatro partes: Fonologia, Morfologia, Sintaxe e Léxico. Integrando essa última um vocabulário assim definido pelo autor numa página final (observações):

Isto não passa de uma tentativa de vocabulário das locuções populares do Rio de Janeiro; é um ligeiro esboço que outros poderão melhorar.

Reconhecemos que há quem melhor do que nós, pode fazer êste trabalho. Raul Pederneiras, o apreciado autor das Scenas da Vida Carioca, Elysio de Carvalho, o compilador do dicionário de gíria, Carlos Bittencourt e Cardoso Menezes, a parceria que na scena teatral tanto tem mostrado conhecer a alma do nosso povo, Oduvaldo Vianna e tantos outros.

Nisto, como em tudo, no começo é que está a dificuldade. Apareçam os aperfeiçoadores (Nascentes, 1922, p. 126).

Como em outras intervenções, nessas observações o autor se apresenta novamente como um inovador que inicia um trabalho cujo começo é sempre difícil e que poderá ser aperfeiçoado.

Em uma cidade atravessada pela mestiçagem, certamente o esboço de vocabulário das locuções populares do Rio provinha da enorme massa de mestiços que tinha sido “expulsa” da região central da cidade em todo o processo de alteração urbanística levado adiante na primeira década do século XX.

No começo do livro, Nascentes se projeta como um autor que vê a constante alteração das línguas. Logo de início expressa que

é facto por demais sabido que, mesmo dentro do próprio território, por diversas causas entre as quais sobresaem a lei do menor esforço e a necessidade de clareza de expressão, as línguas tendem a alterar-se (ibid. p.11, itálico nosso).

E, continua a explicação afirmando que

Maiores alterações sofrem ainda, quando são transplantadas de uma região para outra. Assim, o latim se transformou nas actuais línguas românicas e estas, por sua vez, nas colônias muito vieram a diferir do falar das metrópoles: haja-se em vista o francês do Canadá e o espanhol da América. Outro tanto aconteceu ao português implantado em nosso país (ibid.).

Nessas páginas iniciais, Nascentes deixa entrever a sua concepção histórica do processo linguístico. Essa visão clara da alteração das línguas “transplantadas”, dentre as quais “o espanhol da América”, será fundamental na hora de analisar a Gramática. Nessa textualidade o sujeito se mostra conhecedor das diferenças entre a língua das colônias e das metrópoles (ou ex-metrópoles) e, ao mesmo tempo, consciente de que era necessário 
um estudo apurado para fixar as causas das alterações (ibid.), no entanto, vai apresentando alguns dos motivos mais evidentes:

Nem que fosse falada apenas por portugueses e seus descendentes puros, nem por isso deixaria ela de alterar-se graças às causas que apontamos acima; mas a língua portuguesa no Brasil sofreu grandes alterações porque teve de ser aprendida por homens de duas raças que falavam línguas de estrutura inteiramente diversa do tipo flexional (ibid., p. 12).

O índio foi o primeiro a aprender o português; é natural, pois foi o povo autóctone.

Só mais tarde aparece o outro factor etnográfico, o negro (ibid.).

(...)

Desde meados, pois, do século XVI, colonos portugueses, índios, africanos, seus descendentes puros ou mestiçados, começaram, cada qual a seu jeito, a modificar a língua portuguesa e mais tarde as modificações por eles introduzidas vieram a constituir a variante brasileira.

O afastamento da metrópole, a independência política e outras causas tornaram autônomo o português do Brasil (ibid.).

E citando a João Ribeiro conclui: “a língua nacional é essencialmente a língua portuguesa, mas enriquecida na América, emancipada e livre nos seus próprios movimentos” (ibid.). Como veremos ainda, emancipação e liberdade da língua são recorrentes.

Como apresentam os recortes acima, para Nascentes não era possível que a língua não se transformasse, mesmo que ela "fosse falada apenas por portugueses e seus descendentes”. E mais ainda no Brasil, onde teve que ser aprendida por índios e negros (“duas raças que falavam línguas de estrutura inteiramente diversa do tipo flexional”). $\mathrm{O}$ contato linguístico foi o principal fator de modificação e essas sucessivas modificações constituíram a "variante brasileira”, autônoma do português de Portugal, incluso, pelo “afastamento da metrópole” e pela “independência política”. E na que talvez seja uma das afirmações mais expressivas dessa espécie de manifesto sobre a língua, o autor se mostra sensível à dimensão política da língua:

Submeter o nosso falar diferente às formas portuguesas é um absurdo desprezível e servilmente colonial (...) (ibid.).

Das entrelinhas parece surgir a ideia de uma língua nacional que vai se construinda a partir de particularidades. Não reconhecer a soberania que a língua portuguesa foi adquirindo nos novos territórios, seria “um absurdo desprezível e servilmente colonial”. Para o autor, a língua no Brasil seguiu outros rumos:

Certas leis da gramática portuguesa perderam aplicação entre nós; falamos diferentemente sim que por isso falemos errado, pois nos exprimimos de acordo com os novos rumos por que marchou no Brasil a língua portuguesa (ibid., p.13) ${ }^{94}$.

\footnotetext{
${ }^{94}$ No parágrafo seguinte, o autor afirma que o que se deu com a língua pode ser comparado com o processo de multiplicação vegetal conhecido pelo nome de mergulhia. Como vemos, em suas concepções
} 
Apesar da constante imigração portuguesa, apesar do constante intercâmbio literário entre Portugal e Brasil, nada pode deter a nossa marcha (ibid.).

Era um falar diferente, mas, no entanto, para Nascentes não se apresentava como um falar errado $^{95}$. O português em terras brasileiras “[prosseguiu] hoje evolução à parte”, afirma, “como a península ibérica prosseguiu a sua depois do desmembramento do império romano” (ibid. p. 13). Mais uma vez, o autor compara a evolução do português no Brasil com outros processos históricos de transformação das línguas.

A série de recortes apresentados permite uma aproximação às concepções linguísticas do autor e nos permite inferir, por um lado, que para Nascentes a transformação da língua - que foi constituindo a "variante brasileira"96 - era uma expressão da soberania com relação a Portugal (uma colocação que apresenta uma clara consciência da dimensão política da língua) e, por outro, também podemos inferir que a posição de Nascentes em matéria linguística não era exatamente purista: se por um lado, as diferenças com relação ao português de Portugal não significava “um falar errado”; por outro, nada podia deter a marcha do português do/no Brasil: nem a "constante imigração portuguesa”, nem o “constante intercâmbio literário entre Portugal e Brasil”, dois aspectos que tendiam a manter certa unidade.

Fazemos essa afirmação de uma posição não purista do autor após realizar um recorrido exploratório por diversos materiais, dos quais apresentamos acima alguns recortes - incluída a obra de 1922 -, e após interpretá-los à luz das conjunturas sóciohistóricas de produção: uma época e uma sociedade específica na qual o autor lança as ideias de seus estudos e observações sobre a língua a partir de uma posição diferente à ocupada por uma elite que por esses anos falava em branqueamento racial ${ }^{97}$.

está presente essa ciência linguística biologizante e naturalista, a “ciência aceita” na época a partir da qual vai expandindo as concepções. Retomaremos a comparação e a explicação do processo dada pelo autor ao debatermos com o trabalho de Mattos e Medeiros (2013).

95 Essa é a leitura modernista, lembremos que o lançamento de $O$ linguajar carioca coincide com a semana modernista de 1922, levada adiante em São Paulo.

${ }^{96}$ A questão para o autor era entender se essa variante independente constituía um dialeto. E de forma muito afinada com um saber científico, afirma que a resposta depende do conceito que se fizer de dialeto. Afirmação após a qual faz uma explicação das diferentes compreensões, especialmente a de Leite de Vasconcelos, a quem se refere como “a maior autoridade em dialectologia portuguesa” (Nascentes, 1922, p. 14). Mas para o autor, a questão ia além da designação: "haja ou não haja dialeto brasileiro, questão que se discute desde a célebre polêmica entre Alencar e Castilho, o que não se pode contestar é a existência da variação entre a língua do Brasil e a de sua antiga metrópole e é isso principalmente o que nos interessa e o que nos cumpre estudar" (ibid. p. 14).

${ }^{97}$ Estamos diante de uma sociedade específica e de disputas particulares em torno à língua. Sobre essa questão, parece significativo o livro de Lucchesi (2015): Língua e Sociedade partidas. A polarização sociolinguística do Brasil em que o autor apresenta a constituição do português brasileiro articulado ao processo econômico-social de formação da nação brasileira. O estudioso assinala que "a universalização 
O autor toma ideias da ciência aceita na época e sem estabelecer uma ruptura vai dando corpo a essa voz (e construindo uma posição) que desliza entre matrizes de sentido antagônicas. Uma construção que não poderia deixar de ser oscilante e, por vezes, contraditória. Especialmente dois recortes do prólogo de $O$ linguajar Carioca dão sustento à afirmação que acabamos de fazer e nos permitem rastrear marcas do discurso científico dominante, especialmente ideias naturalistas e derivadas da biologia. Por um lado, o sujeito desse discurso se refere aos estudos de "patologia linguística” que estava empreendendo no livro. Por outro lado, compara a língua com um processo de multiplicação vegetal:

O que se deu pode perfeitamente ser comparado com o processo de multiplicação vegetal conhecido pelo nome de mergulhia: até se criarem raízes, o ramo vergado e mergulhado no solo é sustentado pela seiva vegetal que sofre a operação; uma vez brotadas raízes que possam haurir seiva para a nova planta, um corte no ramo a separa e ela vai separadamente prosseguir sua evolução (ibid. p. 13).

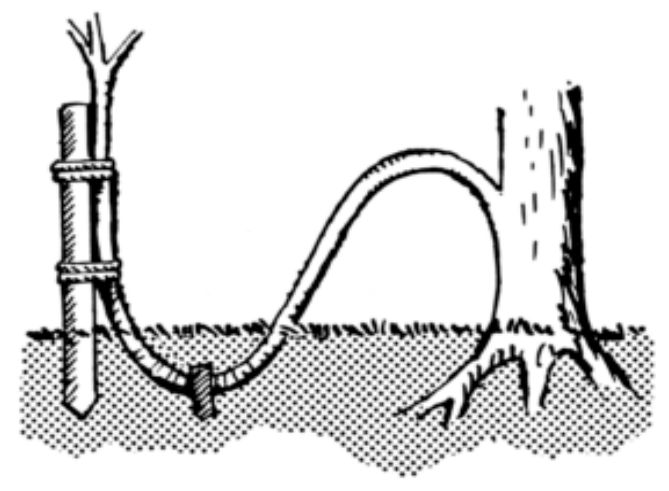

Esquema de uma mergulhia ${ }^{98}$

O mais interessante é que esse fragmento que compara o processo histórico de uma língua com o de multiplicação vegetal, se aproximando na comparação dos discursos provenientes da biologia, vem imediatamente após se referir à autonomia do português do Brasil, à emancipação da língua, a um falar diferente sem que por isso seja errado. Ou seja, se é verdade que a ciência dominante está presente em algumas intervenções de cunho naturalista, também é verdade que esse aspecto não o impede de reconhecer a soberania, independência, emancipação e rumo próprio que a língua foi tomando no Brasil, permitindo-nos identificar, nas diversas afirmações, a posição de um estudioso, marcada por uma consciência clara do processo histórico, social e político de

de representações que atendem a interesses particulares, e não universais, está na base da construção da hegemonia ideológica da classe dominante” (ibid., p. 27), e no plano da língua, reafirma que "essa universalização promovida pelo discurso ideológico transforma a língua da elite na própria língua, abolindo a pluralidade do idioma” (ibid., p. 28).

${ }^{98}$ Extraído de: https://pt.wikipedia.org/wiki/Mergulhia. Acesso: setembro de 2017. 
transformação das línguas. Alguns recortes do interior do livro, especialmente da seção Sintaxe, reafirmam o que acabamos de observar:

Em matéria de colocação de pronomes pessoais oblíquos grande a divergência entre o falar de Portugal e do Brasil (Nascentes, 1922, p. 69).

E nas páginas seguintes, expande essa afirmação em diversos fragmentos, alguns com certa ironia, nos quais fica claro como o autor entende a transformação da língua e o seu uso a ambos os lados do Atlântico:

A nossa maneira phantasista (como alguns lhe chamam) de collocar os
pronomes, forçosamente diversa da de Portugal, não é errônea, salvo se a
grammatica, depois de annunciar que observa e registra factos, depois de
reconhecer que os phenomenos linguísticos tem o seu histórico, a sua evolução,
ainda se julga com o direito de atirar, ciosa e receiosa da mutabilidade, por
cima do nosso idioma, a tunica de Nessus das regras arbitrarias e inflexíveis
(ibid., p. 70-71).
As línguas alteram-se com a mudança de meio; e o nosso modo de falar diverge
e ha de divergir, em muitos pontos, da linguagem lusitana. Muitas são as
differenças actuaes, que passam desapercebidas por não haver um estudo feito
neste sentido. Não é caso para eternamente nos julgarmos inferiores aos nossos
"maiores" (ibid.).
(...)
A verdadeira conclusão scientífica não pode ser senão esta: em Portugal é certa
a collocação dos pronomes por ser de uso geral; no Brasil também é certo o
nosso modo de empregar os pronomes por ser igualmente de uso geral (ibid.) ${ }^{99}$.

Dando continuidade à proposta de transitar pelas leituras realizadas por diferentes autores, nos parece interessante estabelecer um debate com outro trabalho que também analisa o prólogo do livro O Linguajar Carioca, e cujas interpretações apresentam diferenças com as nossas. Mattos e Medeiros (2013) analisaram O Linguajar Carioca em relação a uma obra anterior, pioneira da dialetologia brasileira: O Dialecto caipira, de Amadeus Amaral (1920). Partindo dessas duas obras fundamentais para os estudos dialetológicos no Brasil, os autores buscaram (segundo eles mesmos afirmam), por um lado, identificar posições-sujeito que comparecem no discurso do filólogo da década de 1920 no que diz respeito à língua do/no Brasil e, por outro, compreender de que modo essas duas obras se tocam e se relacionam (em confronto ou em aliança) projetando uma discursividade sobre a língua do/no Brasil.

Mattos e Medeiros se perguntam em que medida comparece no livro O linguajar Carioca, de Nascentes, a memória positivista/naturalista de Amaral (presente no $O$ Dialeto Caipira) que contribui, segundo os autores, para formar em Nascentes uma

99 É interessante observar que nos anos 1990 essa afirmação de Nascentes sobre a divergência na colocação de pronomes pessoais oblíquos (certa tanto em Portugal quanto no Brasil) foi um dos parâmetros que levou Charlotte Galves $(1998,79)$ a afirmar, a partir do gerativismo, que "os falantes de português europeu e de português brasileiro não têm a mesma gramática, ou Língua-Interna”. 
posição discursiva lusitana que coloca a língua do/no Brasil no lugar do erro, do desvio, da deturpação. É especialmente essa conclusão com a que intentamos debater, já que, embora Nascentes faça referência à "patologia linguística" ${ }^{100}$, os recortes acima apresentados e outros que iremos abordando nos levam a afirmar que as ideias linguísticas do autor estavam longe de compreender a língua do/no Brasil como erro, desvio e moléstia. Lembremos, por exemplo, o seguinte recorte apresentado anteriormente: “Certas leis da gramática portuguesa perderam aplicação entre nós; falamos diferentemente sim que por isso falemos errado [...]" (itálico nosso). Ou, inclusive, os recortes que trazem as considerações sobre os pronomes oblíquos.

Poderíamos identificar uma posição lusitana num filólogo que fala da transformação das línguas, da transformação das "línguas transplantadas” e da importância dos contatos linguísticos para que essas transformações ocorram? E, especialmente, poderíamos identificar essa posição (“lusitana”) em um autor que associa língua à soberania? Entendemos que há aqui um ponto importante de divergência entre o recorte do objeto realizado pelos autores e o que tem lugar no presente trabalho. Enquanto Mattos e Medeiros identificam no discurso do autor uma posição lusitana que coloca a língua do/no Brasil como erro, desvio, moléstia - embora reconheçam "sentidos que rompem (em certa medida) com [o] assujeitamento da língua do Brasil à língua portuguesa (ibid. p. 4) -; a nossa leitura coloca o foco no reconhecimento que o autor faz da língua do/no Brasil como sendo um falar diferente, autônomo e soberano das formas que a língua tinha em Portugal.

Anterior ao artigo de Mattos e Medeiros, Mattoso Câmara Jr. ([1972] 2014, p. 39) também realiza uma comparação entre a obra de Nascentes e a de Amaral. O linguista afirma que O linguajar Carioca “estabeleceu a primazia da fonologia e da gramática para caracterizar um dialeto, superando a fase de mera coleta de termos regionais”. Câmara Jr. assinala que Nascentes tinha dado um passo adiante com relação a Amadeu Amaral quem, segundo o linguista, "não soube desvincular-se da indevida supremacia da lexicologia”, relegando informações gramaticais e filológicas a uma breve Introdução do livro O Dialeto Caipira (ibid. p. 40). Como já vimos, o passo adiante dado por Nascentes se fazia necessário para compreender a singularidade do português brasileiro.

100 Os autores identificam, por um lado, uma posição discursiva lusitana e, por outro, pelo fato de identificarem que esse autor vê a língua "no lugar da patologia, da moléstia, organismo lacunar e degenerado, variação doente da língua matriz portuguesa”, reconhecem uma "memória naturalista" (Mattos e Medeiros, 2013, p. 2). 


\subsubsection{Aproximações e afastamentos do discurso dominante}

Até aqui apresentamos, permeada por nossas leituras e interpretações, a posição que Nascentes vai assumindo com relação à língua portuguesa do/no Brasil. Uma posição que envolve identificações com o discurso dominante na ciência, mas que não o impedem de ampliar a visão sobre a língua, apresentando uma compreensão histórica, política e social das transformações do português em terras brasileiras. É a partir dessa visão ampliada que, entendemos, se constrói e se faz ouvir uma voz particular, nem lusitana nem purista. Nesse esforço ficam as marcas das tensões que esse vaivém de aproximações e afastamentos produz; contradições, aliás, constitutivas de qualquer discurso.

A nossa interpretação sobre uma não ruptura com o discurso dominante está configurada por dois aspectos. De acordo com o primeiro, Nascentes parece ter claro que há uma ciência aceita numa determinada época e que é a partir dela que outras construções são possíveis. Diversas marcas dão sustento à nossa afirmação. Reconhecemos uma delas no texto Adolfo Coelho e a Etimologia (Nascentes, [1949], 2003g), no qual Nascentes comenta o Dicionário Manual Etimológico da língua portuguesa (de Coelho, 1890) em relação à etimologia.

Do seu artigo em defesa ao Dicionário de Coelho, trazemos palavras que iluminam esse aspecto da nossa interpretação, especialmente quando argumenta para refutar a crítica feita por José Leite, quem afirma que "pretende ser etimológico”, que “nada ou pouco adianta ao que se lê em Diez ${ }^{101}$ ” e que "peca por métodos e por definições” (Nascentes, 2003g, p. 733). Refutando as palavras de Leite, Nascentes afirma:

Não pretende ser etimológico; é. Com todas as suas lacunas, com todos os seus erros. Até hoje se consulta, nem que seja para divergir da sua opinião" (ibid.).

Para Nascentes "foi uma obra útil que levou a etimologia portuguesa a um ponto que ela não havia ainda alcançado" [...] "preparou o terreno para os que vieram depois e nisto está o seu maior mérito” (ibid., p. 734). Mas o mais interessante para o nosso argumento está no seguinte recorte que mostra, também, uma sensibilidade a respeito do funcionamento da memória:

\footnotetext{
101 Frederico Diez (Friederich Christian Diez) de Giessen, Alemanha, nascido em 1794 e falecido em 1876, é considerado o fundador da filologia românica ao publicar a sua Gramatik der romanischen Sprachen, Gramática das línguas românicas (1836-1844), onde aplica o método histórico-comparativo. Disponível em: http://topicosdelatinidade.blogspot.com/2011/12/filologia-romanica-e-seu-fundador.html. Acesso em: 6/10/2018.
} 
Repetiu o que disse Diez, como não podia deixar de repetir: era a ciência aceita na época, do mesmo modo por que quem veio depois de Meyer-Lübke não podia deixar de repetir Meyer-Lübke. Não se vão inventar etimologias estapafúrdias só para divergir de Diez ou divergir de Meyer-Lübke (ibid., p. 733).

Como Coelho, também Nascentes parte da ciência aceita na época para, a partir daí ampliar e construir outra visão. As palavras do autor no próximo recorte fecham este aspecto da nossa interpretação sobre o modo como esse estudioso pensava a relação entre a produção de conhecimento linguístico e a ciência aceita numa determinada época e, a modo de dobradiça, produzem um enlace com o outro aspecto proposto, o viés biográfico:

Aproveitando-se da ciência de Diez, prestou um grande serviço aos que não podem adquirir a obra do mestre alemão, aos que, podendo adquirir, não conhecem a língua alemã e por isso não poderiam utilizar-se dela (ibid., p. 734).

Nascentes tinha uma forte consciência da sua própria história e essa consciência atravessa também seus escritos. Vale lembrar que ele não tinha podido adquirir nem o trabalho de Diez nem o Dicionário de Coelho, obra que, copiando uma a uma as definições, servira de base para a elaboração de seu próprio Dicionário Etimológico $(1931)^{102}$. A sua história pessoal ("nascido na humildade, crescido no estudo e feito por si, na árdua arremetida contra um mundo hostil” (Oiticica [1933], 2003, p. 171)) marca, sem dúvida, suas posições. Nascentes termina o artigo afirmando:

Esses dicionários lacunosos e errados, sobre os quais os críticos se atiram com unhas e dentes, uma virtude ao menos possuem: dão azo a que certas origens sejam reestudadas com elementos novos e assim a ciência vai progredindo, até um dia ter-se então a obra perfeita, sem erros, sem lacunas, que eles ajudaram a erguer. Glória, pois, a Adolfo Coelho, o benemérito que colocou a Filologia Portuguesa em bases verdadeiramente científicas (2003g, p. 734-735).

O recorte permite acompanhar o reconhecimento de Nascentes para os esforços de quem ia (como ele próprio em outras situações, inclusive em $O$ linguajar carioca) abrindo caminhos. Como já expusemos ao falar da sua vida, a produção de conhecimento desde um lugar subalterno - como entendemos que era ser mulato nessa sociedade que falava em eugenia - não segue o mesmo percurso, nem tem o mesmo formato que quando se fala a partir de posições ocupadas pela elite branca que não só

\footnotetext{
102 Nascentes foi, justamente, um dos que vieram depois de Coelho, e um dos que pode aproveitar o que esse dicionário tinha avançado nos estudos etimológicos, especialmente para a produção de seu próprio trabalho.
} 
tinha o controle político e econômico do país, mas também, na sua grande maioria, o da produção de conhecimento ${ }^{103}$.

Nessa sociedade complexa e desigual, e dentro de um espírito de época em que os intelectuais vindos da elite rural e política se perguntavam “que lugar atribuir ao africano e seus descendentes, ex-escravos recém libertos” e “como garantir a vitória da civilização sobre a barbárie em uma terra povoada por uma maioria de negros, índios e mestiços” (Ventura, 2000, p. 331), Nascentes ia produzindo seus trabalhos e fazendo suas leituras.

Com relação ao português, a posição que vai sendo traçada nos escritos parece clara. É sua “língua materna” e é a língua nacional, na relação de (dis)continuidade apontada por Payer (2006). É a língua da escolarização e a língua sobre a qual desenvolveu suas pesquisas e sobre a qual escreveu ao longo de seis décadas, pensando nela como uma língua de “dialetos” e "falares”. Ao irmos ao espanhol e à Gramática produzida para ensinar a língua na escola secundária, o movimento é diferente, embora também possa ser rastreada, como no português, essa relação (inclusive mais estreita) com o discurso dominante. E como no português, também são apresentados outros dizeres e algumas controvérsias com as que o autor parece se identificar. Um movimento que produz oscilações entre uma norma mais purista (da variedade culta do centro norte da Espanha) e tímidas pinceladas de diversidade da língua, apresentadas de forma mais periférica.

A relação com a língua espanhola é diferente, o espanhol é uma língua estrangeira, uma língua que Nascentes teve que estudar (imaginamos que de forma autodidata) para fazer o concurso, para produzir a tese do concurso e para poder escrever a Gramática. Nesse movimento, os instrumentos linguísticos que funcionaram como fonte foram fundamentais no processo de produção. Como apresentado no final do capítulo anterior, a obra chave para a elaboração foi a Gramática da RAE de 1917. E já na Introdução, as representações sobre a língua estrangeira se apresentam enraizadas em uma matriz linguística peninsular ${ }^{104}$, não sem certos vaivens que abordaremos na próxima seção.

103 Fazemos essa afirmação, mesmo sabendo que os negros que ascendiam socialmente “embranqueciam”, como afirma Lucchesi (2015). O autor cita o caso de Machado de Assis e afirma que nesses casos ocorria a assimilação dos modelos linguísticos da elite, fato que era condição para tal ascensão social. Embora, no caso de Nascentes possa ter existido esse “embranquecimento” - não só pelo ascenso social, mas também se observarmos que Nascentes produziu parte da sua obra dentro do aparelho estatal - entendemos que o fato de ser negro marca as posições discursivas identificadas nos diversos escritos produzidos ao longo da sua vida.

${ }^{104}$ Ao longo do trabalho tomamos o termo "matriz" (matriz linguística, matriz discursiva), não como um conceito alinhado a alguma teoria ou pensamento de autor, mas no sentido corrente do termo que poderia 


\section{Língua e norma na Gramática}

Qualquer padrão linguístico é uma criação histórica, produto de complexos processos de codificação, embora o imaginário social o acabe identificando simplesmente com a própria língua (Lagares, 2011, p. 9).

Nesta seção, vamos abordar alguns aspectos da Gramática de espanhol para uso dos brasileiros, observando o movimento que vai vinculando a língua a um determinado padrão linguístico que, como afirma Lagares na epígrafe escolhida, é "uma criação histórica”. Diante dessa afirmativa caberia perguntar: quais são as tensões nesse processo de elaboração que vincula a língua a um padrão linguístico? E quais são os efeitos quando se compreende essa questão como uma questão política (ibid. p. 10)? Se, como afirma Monteagudo (2011, p. 39), “a base do código normativo padrão é uma variedade linguística associada a usos e usuários privilegiados ${ }^{105}$ ”, parece interessante rastrear como acontece isso na Gramática, enquanto instrumento linguístico da língua espanhola produzido no Brasil.

Parte das reflexões propostas se centra na compreensão da força simbólica da norma - ou parâmetro, ou modelo de língua ideal (Bagno, 2011, p. 359) - que se desenha na Gramática e nos efeitos dessa força na construção de uma memória sobre a língua. Como em outros processos históricos, vincular a língua a um determinado padrão constitui, segundo Bagno (2011, p. 365), "um processo de seleção e, como todo processo de seleção, um processo simultâneo de exclusão”.

se aproximar ao de "molde”, "forma”, "contorno" ou, inclusive, ao de uma série de regularidades geradora de outras.

${ }^{105}$ No trabalho, o autor se refere à base do código normativo padrão que se estabelece numa língua nacional. Embora a nossa pesquisa abranja um plano de reflexão diferente (já que pensamos no modo como se gramatiza o espanhol para ser ensinado como língua estrangeira nos anos 20 no Colégio Pedro II), entendemos que constitui uma reflexão produtiva ao pensarmos o código normativo que se plasma em uma gramática elaborada para ensinar a língua na escola secundária. De fato, a maior parte das reflexões e debates sobre a norma linguística foram traçados por estudiosos de diferentes perspectivas teóricas para refletir, especialmente, sobre a constituição das línguas nacionais. Tentamos aproveitar as ideias e questões colocadas nesse outro plano, buscando compreender as particularidades de pensarmos a gramatização de uma língua estrangeira (próxima e vizinha): quais seriam os aspectos que dão a essa gramatização uma fisionomia particular? Na mesma direção que Monteagudo, Bagno (2011) se pergunta sobre os critérios (sempre políticos, diz o autor) que poderiam ser empregados para definir uma língua oficial (está pensando na constituição dos Estados nacionais a partir do Renascimento) e continua: "em meio à diversidade linguística que sempre caracterizou todos os países da Europa, que língua ou que variedade de língua será arrancada de sua dinâmica social para se transformar em monumento, em símbolo de identidade nacional” (ibid., p. 365). Com muito cuidado, essa questão poderia passar por um processo de transposição para as nossas preocupações. Nas indagações deste trabalho a questão seria entender que variedade do espanhol se transforma em "monumento" da língua ou "modelo de língua ideal", projetando uma representação da língua estrangeira e, fundamentalmente, por meio de que processo. 
Diante dessas questões, cabe perguntar: que se seleciona e que se exclui da Gramática? E por meio de que processo são produzidas as descrições e prescrições sobre a língua?

Como apresentamos no capítulo 1, a obra foi produzida para atender as demandas surgidas como efeito da política linguística do Estado (lei n. 3.674, de 7 de janeiro de 1919): a incorporação do espanhol ao já existente ensino plurilíngue no Colégio Pedro II. O autor, Antenor Nascentes, fora o primeiro colocado no concurso público para assumir a cadeira e escrevera a Gramática acompanhando os pontos que tinham sido fixados no Programa de Ensino da disciplina, aprovado pela Congregação do Colégio em 5 de abril do mesmo ano e publicado no Diário Oficial. Desse modo, o próprio programa da disciplina é um determinante estrutural da obra já que vai estabelecendo o que se seleciona e o que se exclui. Se o autor poderia ter "certa autonomia” na forma de abordar as temáticas, é verdade que os tópicos desse programa delimitam aspectos que deveriam ser abordados, tópicos gramaticais que também vão delimitando a língua e a norma que determina o uso.

A Gramática está organizada da seguinte forma: uma Introdução escrita pelo autor na qual se abordam os motivos de sua incorporação como instrumento linguístico no Colégio Pedro II e se expõem questões da história da língua e do método de trabalho. Após a Introdução, 27 capítulos que abordam um amplo espectro dos pontos apresentados no Programa. Uma terceira seção apresenta o que o autor denomina Parte Pratica ${ }^{106}$, com 32 lições dedicadas a vocabulários específicos e encabeçada por uma espécie de introdução própria “O ensino prático do hespanhol”; nela o autor reflete sobre o caminho que um ensino prático deve seguir, sobre os métodos que existiam para o ensino de diversas línguas estrangeiras e, finalmente, sobre o "estreito parentesco entre o espanhol e o português” e a necessidade de levar em conta tal particularidade. Fechando o livro está incluída a carta enviada pela Real Academia Espanhola em 29 de outubro de 1920 a propósito da tese de concurso do autor para a cadeira de espanhol do Colégio Pedro II, enviada por Nascentes a essa instituição ${ }^{107}$.

\footnotetext{
${ }^{106}$ Essa seção aparece a partir da $2^{\mathrm{a}}$ edição, de 1928.

107 Cabe registrar aqui que nessa carta de agradecimento pelo envio do exemplar parte do título da obra foi retirada. Fazemos a transcrição na íntegra, porque ela antecipa um aspecto que voltará a acontecer na obra de Becker, como veremos no capítulo 4:

“La Real Academia Española acordó a una voz, en junta celebrada anoche, dar a V. cordialísimas gracias por el testimonio de consideración y aprecio con que se ha servido favorecer a este Cuerpo literario, dedicándole para su Biblioteca un ejemplar de su obra titulada "Um ensaio de phonetica diferencial luso-castelhana” [havendo sido retirada a segunda parte do título da tese: "Dos elementos gregos que se encontram no espanhol”].
} 
Embora a produção da Gramática vincule fortemente a língua ao dispositivo normativo da Gramática da RAE, na obra vão sendo apresentadas algumas pinceladas de diversidade e certas controvérsias que assinalam, mesmo que timidamente, o que eram suas concepções linguísticas. Seguindo essa afirmativa, dividiremos o movimento de análise em dois momentos: no primeiro, rastrearemos as marcas que na obra dão contorno às ideias linguísticas de uma ideologia dominante assentada na Gramática da RAE de 1917, mapeando o processo que recorta e estabiliza determinados saberes. No segundo momento, tentaremos mostrar que, embora sejam valorizados os parâmetros impostos pelo dispositivo normativo da Gramática da RAE, também podem ser rastreadas marcas que funcionam como indicio de um sujeito que no trabalho de autoria desse instrumento linguístico reconhece a diversidade sociolinguística do mundo hispânico e traz outros dizeres, ampliando assim a compreensão sobre a língua e, consequentemente, mesmo que de forma suave, sobre a norma.

\subsection{Enraizamento em uma norma central}

Pelas ideias expostas nesse texto programático, entendemos que a Introdução da Gramática de Nascentes pode ser dividida em duas partes. Na primeira, o autor fala da origem da língua (“latina”, “como o português”), de certas características no modo de projetá-la (“sonora, graciosa”), do número de falantes e dos espaços (até os mais remotos) onde a língua é falada. Também são abordadas algumas questões já trabalhadas no capítulo 1: as relações constantes com os países da região, a vantagem de estudar o português e o espanhol de forma não perfunctória e a incorporação da língua no Colégio Pedro II em reciprocidade ao gesto do governo uruguaio. Também, a extrema semelhança das línguas, do que decorre para o autor a necessidade de "fixar especialmente o que há de diferente”, reforçando que foi esse “o escopo” do trabalho.

A partir daí e definido o escopo, o que chamamos de segunda parte, na qual o autor se aproxima da língua e da história da língua e sua denominação. Nesse movimento reconhecemos aspectos que nos levam a falar em "enraizamento em uma norma central”: por um lado, o lugar hierárquico dado à Real Academia Espanhola (“autoridade soberana”) e aos instrumentos linguísticos por ela produzidos (ortografia,

Lo que tengo la honra de comunicar a V. cuya vida guarde Dios muchos años.

Madrid, 29 de octubre de 1920

El secretario

Emilio Cotarelo" 
dicionário e gramática) e os efeitos na posição central que a variedade do centro norte da Espanha vai ocupando no texto. Por outro, o lugar dado à Espanha e aos espanhóis, como espaço geopolítico e sujeitos de referência com relação à língua. Esses aspectos compõem este item e serão observados respectivamente em 2.1.1. e 2.1.2, especialmente com recortes da Introdução da Gramática, mas também com outros do interior do livro.

\subsubsection{A RAE e a variedade central}

Definido o escopo, na primeira aproximação da língua é apresentada a instituição - a Real Academia Espanhola - e os instrumentos linguísticos - o dicionário e a gramática - que fizeram do espanhol uma "língua disciplinada”:

O espanhol é talvez a língua mais disciplinada que haja. Filipe V em 1713 fundou uma academia da língua, a qual, entre outros encargos, recebeu o de elaborar uma gramática e um dicionário. O dicionário apareceu em 1726 e está hoje na $15^{a}$ edição; a gramática surgiu em 1771, sendo de 1917 a última edição (Nascentes, 1934, p. 4).

À diferença do português, projetada como língua de “falares diferentes” e “dialetos”, na qual Nascentes reconhece “a variante brasileira” autônoma do português do Portugal ${ }^{108}$, o espanhol é antecipado aqui como uma língua “disciplinada”, talvez, a “mais disciplinada que haja”. A fundação da Real Academia Espanhola em 1713 (instituição que se encarregou de instaurar, manter e propagar um modo de disciplinar a língua ao longo dos séculos) esteve estreitamente vinculada ao projeto político de Felipe V. A imposição da língua espanhola funcionou como instrumento de integração (e de fortaleza) do Novo Estado e requeria de um eficaz processo de estandardização, como afirma Fabro (2018), retomando palavras de Medina, Del Valle e Monteagudo $(2015)^{109}$. Nascentes faz referência a esse processo e à elaboração dos instrumentos linguísticos que sustentaram e projetaram a representação de "unidade da língua”: o dicionário (1726) e a gramática (1771) ${ }^{110}$, sendo de 1917 a última edição e a que o autor cita. Essa alegada unidade linguística, como assinala Luis (1998), não era dada ou pertencente à língua, mas construída historicamente.

108 Esse modo como Nascentes vê a língua encontraria formulações muito mais contundentes nos trabalhos de Galves (1998) - a partir do gerativismo - e de Orlandi (1994) - a partir da Análise do Discurso. As autoras chegam a falar em duas línguas.

${ }^{109}$ MEDINA, Alberto; DEL VALLE, José; MONTEAGUDO, Henrique. Introducción a la creación del español: perspectivas ibéricas. In: DEL VALLE, José (ed.) Historia Política del español. La creación de una lengua. Aluvión Editorial, 27-36, 2015.

110 À publicação do dicionário - em seis volumes escritos entre 1726 e 1739 - seguiu-se uma ortografia, em 1741 e, finalmente, uma gramática, em 1771 (Fabro, 2018). 
Sobre esse alto grau de estandardização e controle, Blanco (1999, p. 80) - quem estudou gramáticas e antologias no período de reorganização da escola secundária na Argentina no final do século XIX, destacando o caráter altamente purista das primeiras $^{111}$ - afirma que a Real Academia Espanhola "se reservaba el derecho de legislar sobre la lengua y rechazaba todo apartamiento de la norma que imponía a través de su gramática y su diccionario"112. Já Manzione (2018), num trabalho com observações próximas às de Blanco, mas centrado no Uruguai, discute aspectos vinculados ao purismo e nacionalismo na produção de instrumentos linguísticos durante a expansão da escola secundária nesse país, ao longo da segunda década do século XX. A autora analisa uma série de obras produzidas nesses anos, especialmente a Gramática razonada del idioma castellano ([1910] 1913) de Francisco Gámez Marín. No trabalho assinala-se que o autor indicava à RAE como referente da unidade da língua. Vejamos:

fieles a nuestro deseo de allanar dificultades y atentos à Pedagogía, hemos seguido los preceptos y resoluciones de la Real Academia, así como también, en cuanto ha sido posible, la nomenclatura de la docta Corporación (Gámez Marín (1913) apud Manzione (2018, p. 13))

Também no Uruguai, o principal manual destinado à escola secundária respeitava os ditames da Real Academia Espanhola para preservar a unidade da língua.

Nesse contexto mais generalizado, Nascentes não podia escapar a esse modelo unitário de língua, e assim como as gramáticas escolares argentinas (com os matizes assinalados em nota) e uruguaias, enraizava as representações numa matriz que projetava a ideia de norma central por meio de um sistema normativo que tem sua origem na "autoridade soberana da Academia”:

Em matéria de ortografia, prosódia, morfologia, purismo de linguagem, vernaculidade, a autoridade soberana da Academia é obedecida sem discrepância; por isso a citamos sempre que queremos afastar contestações (Nascentes, 1934, p. 4) ${ }^{113}$.

\footnotetext{
${ }^{111}$ Referindo-se às gramáticas, a autora afirma que "describir e prescribir son dos momentos de una única función: fijar arbitrariamente un modelo de lengua” (Blanco, 1999, p. 100).

112 Arnoux (2017) amplia essa questão e afirma que a classe dirigente recorre a esses autores de gramáticas, muitos deles espanhóis, dentre outros motivos "para subalternizar a los hijos de inmigrantes que en forma creciente asistían a la escuela secundaria” (2017, p. 38). A perspectiva hispanizante e homogeneizante que difunde a norma acadêmica cumpria essa função. Na implantação dessa medida na escola secundária, esses gramáticos e docentes espanhóis tiveram um papel fundamental. No entanto, Arnoux também destaca o fato de que os diversos autores manifestavam um olhar particular sobre os fatos da linguagem, expondo diferenças no registro dos usos locais, na própria distância entre norma e uso e na tolerância às transgressões. Pode-se observar que a norma era instaurada de forma geral, mas não hegemonicamente.

113 No texto Figueiredo esse mal julgado ([1955] 2003f) Nascentes faz uma defesa ao dicionário de Figueiredo. No decorrer do texto o autor afirma: "não quero dizer, com a minha defesa de Figueiredo, que o seu Dicionário seja um guia absolutamente seguro, como são o Larousse, o Dicionário da Real
} 
A “autoridade soberana” dessa instituição, “obedecida sem discrepância”, é anunciada por meio de um sintagma indeterminado que apaga o agente. Quem a obedecia sem discrepância? A força da indeterminação, a falta de especificação do sujeito e o modo como se apresenta sua autoridade produzem um efeito de generalização e de evidência: a RAE era obedecida por todos, inclusive por Nascentes que parece se identificar ao fazer esse reconhecimento, embora a voz da Academia não seja a única presente na Gramática $^{114}$. Nesse sentido, as fontes consultadas e citadas pelo autor são diversificadas mostrando, ao apresentar posições distintas, que a descrição linguística está sujeita a controvérsias ${ }^{115}$. No entanto, o discurso dá pistas da hierarquização que o agenciamento das vozes produz no decorrer do texto. É possível reconhecer na Introdução uma tomada de posição do autor: a naturalização de uma norma linguística central (citada para afastar contestações) que vai configurando uma unidade imaginária da língua. O não dito, o silenciado nesse discurso normativo que se impõe a partir de um centro, diz respeito à relação da língua com a história (Gadet, Pêcheux, 2010) - uma história de conquista e colonização - e à construção política desse imaginário de língua.

No interior do livro esse aspecto é reforçado de dois modos. Por um lado, explicitando “a autoridade soberana da Academia” e, por outro, colocando a variedade do centro norte da Espanha numa posição central. Com relação ao primeiro, no capítulo IV - "Prosódia”, o autor afirma:

Não há dúvida sobre a acentuação de palavra espanhola alguma. Neste particular, como em ortografia, a Academia com sua soberana autoridade em boa hora procedeu a uma completa sistematização (Nascentes, 1934, p. 19).

Academia e tantos outros” (p. 740). Vê-se que os instrumentos linguísticos da RAE tiveram para o autor uma voz de autoridade.

${ }^{114}$ Parece interessante trazermos uma observação de Luis (1998) que, embora abordando outra questão com relação à RAE, retoma os efeitos e sentidos implicados numa indeterminação/generalização que, por sua vez, produz um efeito de invisibilização. Diz o autor: "la firma RAE implica el anonimato de los autores: una gramática sin yo ni nosotros, la impersonalidad del academicismo. La firma como institución no deja ver a los individuos, y esa invisibilidad produce el efecto de que es la lengua misma la que declara las reglas” (ibid., p. 35).

115 Essa observação parece se aproximar da que faz Mattoso Câmara Jr. ([1972] 2014), com relação ao português, ao comentar o Dicionário Etimológico de Nascentes, obra cujos primeiros esboços datam de 1920 e que se termina de imprimir em outubro de 1932. Câmara afirma que "nas etimologias controvertidas [Nascentes] limita-se quase sempre a enumerar os étimos propostos, sem uma escolha explícita entre eles, e evita apresentar outras por conta própria” (ibid. p. 39). Parece ser esse um dos procedimentos que em alguns pontos específicos Nascentes adota no interior da Gramática, quando apresenta comentários de diversos autores sobre um mesmo assunto, por vezes destacando a hierarquia da Academia e, em outras, apenas mencionando o que dizem ao respeito esses autores, sem assumir nenhuma posição. 
No Capítulo XX - "Syntaxe do pronome”, identificamos outro recorte que assinala a importância da Academia nas controvérsias sobre a língua:

A colocação dos pronomes antes ou depois do verbo tem variado muito. Os clássicos usavam-nos enclíticos mais do que hoje se usam; nas Astúrias e em Leão ainda hoje domina a ênclise (ibid. p. 91).

Primeiro são apresentados diferentes usos e, a continuação, diz-se com relação a eles: “A Academia em boa hora estabeleceu as seguintes regras" (ibid.), que passam a ser listadas para indicar que é preciso se ater a elas. No entanto, mais do que as regras estabelecidas, interessa-nos esse lugar dado à Academia que, “em boa hora”, ajuda a resolver as controvérsias e deixa clara a norma linguística. Rastros que no discurso funcionam como indícios do funcionamento da ideologia, neste caso, a naturalização pelo modo como se apresenta uma autoridade soberana que dita as normas linguísticas.

Passamos a examinar algumas marcas que colocam a variedade do centro norte da Espanha numa posição central, reforçando a lógica centro/periferia e atribuindo às particularidades excluídas valorações negativas e predicações de modalidade deôntica como: “não deve ser pronunciado”, “grave defeito”, “é um barbarismo”. Valorações que na observação do erro, do defeito e do que não deve ser pronunciado introduzem um forte aspecto normativo-prescritivo que apresenta uma variedade como legítima e assinala o que fica fora da língua: as variedades rechaçadas ${ }^{116}$.

Encontramos marcas dessas valorações negativas no capítulo 1, dedicado ao alfabeto e à pronúncia das letras:

o $c$ brando não deve ser pronunciado como s, como faz a generalidade dos americanos; isto constitui um grave defeito que os espanhóis chamam sesear" (Nascentes, 1934, p. 8, itálico nosso) ${ }^{117}$.

Acentua-se o caráter normativo-prescritivo do texto escolar, sancionando a pronunciação indistinta do $c$ e dando um lugar de destaque para a oposição produzida nessa variedade peninsular (entre sibilantes dentais e alveolares). Adota-se um critério purista que considera um "grave defeito” essa característica fonológica general do espanhol falado na América. Mais adiante, e ainda sobre a necessidade de oposição, o autor afirma: "é um barbarismo pronunciar o z como s” (ibid. p. 11). Esses aspectos levariam a concluir que

\footnotetext{
${ }^{116}$ Fazemos essa afirmação com base em Arnoux (1999).

117 O seseo significa a pronunciação indistinta do c, do s e do z. A afirmação feita no recorte implica tomar a variedade do espanhol de Castela como norma padrão a partir da qual o resto é caracterizado. $\mathrm{E}$ nessa caracterização omite-se que o seseo - a falta de oposição entre sibilantes dentais e alveolares - não só é um traço fonológico geral do espanhol americano, mas é compartido também pelo espanhol de Andaluzia e Canárias (Fontanella de Weinberg, 1992, p. 133).
} 
seria um barbarismo o espanhol falado no território americano (e no de Andaluzia e Canárias), já que em toda a sua extensão apresenta a ausência de oposição. E justifica:

a pronúncia diferente destas duas letras às vezes distingue parônimos: casa, caza; losa, loza, o que também se da com o $c$ antes de $e$ e $i$ : cima, sima; concejo, consejo (ibid.).

Blanco (1999), na obra citada acima, observa nas gramáticas escolares produzidas para o ensino da língua na escola secundária na Argentina o tratamento dado a alguns aspectos nos quais o uso do castelhano nesse país foi se afastando da norma acadêmica até conformar uma variedade local. No Curso Gradual de Gramática Castellana, de José Hidalgo Martínez (um docente espanhol que dava aulas em um dos colégios nacionais), assim é tratada essa peculiaridade prosódica com relação ao uso de $c, s$ e $z$ que acabamos de apresentar:

C, S, Z. No hay vicio más arraigado, sobre todo en los americanos, y más difícil de corregir, que el de dar a las letras c, s y z un mismo sonido, no pudiéndose distinguir por él el diferente significado de las palabras baza y basa, caza y casa, cima y sima, cocer y coser, lazo y laso, loza y losa, maza y masa, riza y risa, roza y rosa, etc. (Hidalgo Martínez apud Blanco, 1999, p. 85).

A continuação o autor dá uma recomendação aos professores para "la corrección de estos vicios” (ibid.).

Como já foi dito, a obra chave na elaboração da Gramática produzida para ensinar espanhol no Colégio Pedro II tinha sido a Gramática da RAE de 1917. No entanto, no diálogo com o trabalho de Blanco buscamos registrar que essa era a norma instaurada (de modo geral, mas não totalmente hegemônico) no ensino da língua em grande parte do mundo hispânico e, dessa forma, a norma que se instaurava, também de forma generalizada, quando essa língua se ensinava como estrangeira. Vemos que Nascentes pouco se afasta do modo como a língua era apresentada, por exemplo, nas gramáticas escolares na Argentina e no Uruguai.

Em mais um caso que interpretamos na direção de privilegiar uma língua central que apaga as variedades do território americano, no Capítulo X - "Pronomes”, o autor afirma:

\footnotetext{
o pronome sujeito da segunda pessoa do plural é vosotros, reservando-se vos para quando se fala com Deus ou aos Santos, para composições dramáticas, para certas peças oficiais onde a lei ou o costume o exige, para a poesia, onde aliás hoje é raro este uso (p. 41).
}

A língua é a materialidade do discurso, e este, um dos espaços onde a ideologia se mostra. Novamente se vislumbra o apagamento de uma regularidade do espanhol no espaço americano que, como traço gramatical geral, perde a oposição vosotros / ustedes 
para o tratamento plural de segunda pessoa. Um apagamento que ainda hoje, quase um século depois, está presente em alguns instrumentos linguísticos produzidos na Espanha que circulam no Brasil. É interessante observar, mais uma vez, que se para o autor, as relações com os países vizinhos tinham sido a justificativa para incorporar o aprendizado de espanhol na escola, de modo geral, o lugar desses espaços (com seus falantes) não é protagônico nas referências linguísticas ou nos seus modos de falar, surgindo aí uma subordinação com relação à norma central.

Não só a Gramática da Academia de 1917 foi produzida a partir de uma língua unitária, mas também a de Bello, outro dos autores citados e um dos gramáticos hispano-americanos mais importantes, como apresentamos no capítulo anterior. Arnoux (2008) assinala que em 1934 Bello publica diversos artigos no Chile, nos quais adverte sobre o uso da língua castelhana, se centrando para isso nos usos impróprios e defeitos que observara no Chile (onde tinha chegado em 1929, informa a autora) e sobre a necessidade de extirpar os atentados à norma, norma essa também instituída a partir de uma compreensão unitária da língua.

A centralidade da variedade castelhana é reforçada na Gramática de Nascentes em um capítulo que aborda dois tópicos que não estavam formulados no Programa da disciplina: os barbarismos e os solecismos ${ }^{118}$. Esses tópicos introduzem uma forte questão normativa, iluminando com força a regra e apontando para o que está “errado”. Novamente, a regra formulada a partir de uma concepção unitária de língua.

Vale a pena aqui ampliar a reflexão. Tentando compreender essas questões sobre a regra e o que está errado, Auroux se pergunta, na reflexão empreendida no livro Filosofia da Linguagem, “o que é uma regra?” (2009b, p. 81). Na resposta, afirma que

sob sua forma mais explícita, é o enunciado de uma estipulação que basta seguir para obter, a partir de elementos dados, uma frase correta na língua em questão. A noção de "correção" introduz um aspecto "normativo": passam a existir "erros" (os antigos reconheciam essencialmente dois deles: o barbarismo e o solecismo). O “erro" é imputável ao fato de não se seguir uma "regra" (ibid. p. 81-82).

Como vemos, "barbarismo" e "solecismo" são categorias gramaticais que existem desde a antiguidade e assinalam o que está “errado”, o que não segue a regra. Gadet e Pêcheux (2010, p. 30) também fazem referência aos barbarismos quando abordam as controvérsias no modo como historicamente se refletiu sobre a linguagem e,

\footnotetext{
118 O ponto 21 do Programa está dedicado a Gramática histórica: “Alterações lexicais: archaismos, neologismos e idiotismos. Modificações sofridas pelo hespanhol nas Repúblicas Americanas” (Diario Oficial, 5 de julho de 1919). Note-se que não há referências a barbarismos e solecismos.
} 
especialmente, sobre as diversas formas de olhar para as “irregularidades”. Nessa reflexão, apresentam o modo como, desde antes de se configurar uma ciência linguística “o fato da língua já se encontra[va] no centro do debate” e fazem um percurso mostrando como as controvérsias que durante séculos opuseram grupos antagônicos estão presentes, com efeitos "transformados ou deslocados", nos confrontos mais recentes (ibid. p. 29).

Os autores afirmam que, embora as posições tenham mudado ao longo do tempo, “a questão de um real da língua inscreve-se nessa disjunção maior entre a noção de uma ordem própria à língua, imanente à estrutura de seus efeitos, e a de uma ordem exterior, que remete a uma dominação a conservar, a reestabelecer ou a inventar”. É nesse ponto que abordam a designação arcaica de barbarismo, que julgam “ao mesmo tempo linguística e política” (ibid., p. 30). Vale a pena reproduzir o contexto mais amplo em que eles abordam essa categoria:

\footnotetext{
Para os que sustentam que a língua trabalha com a existência de uma ordem própria, o real da língua reside naquilo que dela faz Um, a assegura no Mesmo e no Idêntico e a opõe a tudo o que da linguagem cai para fora dela, nesse inferno ininteligível que os Antigos designavam pelo termo "barbarismo": o campo do interdito na linguagem é, assim, estruturalmente produzido pela língua, do interior dela mesma (ibid.).
}

Os barbarismos (vistos como aquilo "que da linguagem cai para fora dela”) constituem um campo de interdito. E “é justamente nesse ponto do interdito em que os adversários dessa posição situam suas suspeitas” (ibid.). Segundo Gadet e Pêcheux, “eles não querem ser enganados por uma obrigação social dissimulada em uma ordem natural, por uma coação política, fazendo-se passar por necessidade linguística” (ibid.). Os autores se perguntam, então, sobre a ordem da língua, uma ordem que para eles não é "nada mais do que a ordem política na língua”. E arrematam: “uma incessante vigilância de tudo o que - alteridade ou diferença interna - arrisca questionar a construção artificial de sua unidade e inverter a rede de suas obrigações” (ibid. p. 31). As palavras de Gadet e Pêcheux fazem clara referência à construção artificial da unidade da língua como efeito do processo de padronização.

Essa categoria sobre a qual acabamos de refletir - "Barbarismos e solecismos" teria, assim, um forte caráter normativo. Embora não fizesse parte do Programa de espanhol do Colégio Pedro II como tópico específico, o seu estudo foi proposto por Nascentes e tratado no capítulo XXIV. Nesse capítulo, as palavras iniciais colocam novamente a Academia como autoridade inconcussa (sólida e inabalável) que não pode 
ser contestada: "Vejamos os barbarismos capitulados pela Academia neste ponto autoridade inconcussa”, diz Nascentes (1934, p. 107, itálico nosso). Ao cotejar o texto da obra de Nascentes com o da Gramática da RAE de 1917, vemos que foi a partir dela, mas com uma série de reformulações, que o autor escreveu sobre esses aspectos normativos-prescriptivos.

A primeira diferença é não apresentar a definição de barbarismo, altamente normativa, que estava presente na Gramática da RAE da seguinte forma

\begin{abstract}
Capítulo XXVII - De los vicios de dicción. Los principales vicios de dicción en que puede incurrir quien habla o escribe son el barbarismo, el solecismo, la cacofonía, la anfibología u obscuridad y la monotonía y pobreza, o empleo muy frecuente de poco número de vocablos. a) Consiste el barbarismo en escribir o pronunciar mal las palabras, o en emplear vocablos impropios; y el solecismo, en faltar a las reglas dadas acerca del oficio y uso de las distintas partes de la oración [...] (Gramática da RAE, 1917, p. 444).
\end{abstract}

Na obra de Nascentes aborda-se esse tópico sem uma definição prévia, sem fazer referência a vícios de dicção, a defeitos ou àqueles que "escrevem, acentuam ou pronunciam mal”. Assim, na Gramática produzida para os alunos do Colégio Pedro II, o aspecto prescritivo pareceria ter passado por uma modalização.

A Gramática da RAE estabelece as seguintes categorias para o subtítulo "DEL BARBARISMO”. Diz o texto:

incurren en este defecto" [e a continuação são estabelecidas três categorias:] I. Los que escribem mal las palabras" [com os exemplos], 2. Los que acentúan y pronuncian mal [e] 3. Los que truecan por vocablos de otras lenguas los castellanos genuínos y expresivos (ibid.).

Nascentes escolhe outro modo de categorizar que, junto com a ausência da definição inicial apresentada acima, pareceria atenuar a estigmatização do falante. O autor reformula cada uma das categorias mencionadas, e lhes outorga uma nova designação. No primeiro caso, em vez de anunciar a categoria como "los que escriben mal las palabras”, o autor opta por "barbarismos gráficos”. Para a segunda categoria "los que pronuncian y acentúan mal” -, o autor prefere "prosódicos”. A terceira categoria - "los que truecan por vocablos de otras lenguas los castellanos genuínos y expresivos” - é anunciada assim por Nascentes: “A Academia, ciosa do purismo do castelhano, repele o estrangeirismo, seja de que procedência for, até do latim; desde que haja um termo castelhano genuino que seja expressivo da ideia” (itálico do autor, p. 108). Vale notar nesse fragmento um gesto de distanciamento do autor ao registrar a autoria da Academia. 
No capítulo reservado aos "barbarismos" e "solecismos”, no trabalho de autoria da Gramática, o autor poderia, seguindo o pautado pela Gramática da RAE, ter expressado de forma mais contundente o aspecto prescritivo, o "erro". No entanto, observamos certas modalizações nos recortes extraídos da Gramática fonte (a da RAE de 1917), retirando, por vezes, justamente as marcas mais prescritivas.

Voltando à Introdução da Gramática de Nascentes, o próximo fragmento irrompe $^{119}$ de forma bastante indeterminada. Após apresentar a criação da RAE e a elaboração dos instrumentos linguísticos e de argumentar que "a autoridade soberana da Academia é obedecida sem discrepância”, no parágrafo seguinte o autor afirma:

Uma lei de 9 de setembro de 1857 declarou a gramática da Academia o texto único e obrigatório das escolas de ensino (Nascentes, 1934, p. 4).

Diante dessa afirmação cabe perguntar: uma lei de onde? De qual Estado? Onde fora promulgada? E, consequentemente, nessa indeterminação, quais escolas estariam aí referidas. Por que foi necessário declarar essa gramática um “texto único”? Qual é a disputa que embora apagada, mostra-se nas bordas, nas falhas que a materialidade da língua apresenta?

Antes de avançarmos na abordagem dessas indagações, vale a pena mencionar que a Gramática da RAE de 1917 começa a “Advertencia Preliminar” com o seguinte enunciado:

La ley de 9 de septiembre de 1857, en su artículo 88 declara que la GRAMÁTICA de la Academia Española es texto obligatorio y único en las escuelas de enseñanza pública (Academia, 1917).

Ou seja, embora na textualidade da Gramática de Nascentes não apareçam as marcas da citação, podemos inferir que o autor extrai quase que textualmente essa menção. A partir da reformulação feita na obra, cabe perguntar sobre os efeitos que produz a passagem do sintagma determinado na Gramática da RAE: “la ley de 9 de septiembre de 1957” a um outro indeterminado, na de Nascentes: “uma lei”. A determinação linguística que surge na formulação da Gramática da RAE - determinante + núcleo: la ley + sintagma preposicional - suporia a unicidade de um referente. Examinaremos o estudo de Leonetti (1999) para quem, desde um ponto de vista semântico, “los determinantes determinan la referencia del sintagma nominal”. O autor destaca que "la definitud es la indicación de que el referente del SN es identificable para el receptor en el contexto de uso" (ibid, p. 38-39). Dessa forma, percebe-se que a

${ }^{119}$ Entendemos que "irromper" é o melhor significante para remeter a uma formulação que surge de forma isolada, solta e com marcas de indeterminação na horizontalidade do intradiscurso. 
determinação, no caso, permitiria a identificação do referente (da lei e, posteriormente, das escolas em que é aplicada). No entanto, o mais importante para Leonetti é que:

[...] la familiaridad del receptor con el referente no es una condición necesaria y general de la definitud. En muchas ocasiones, los sintagmas nominales definidos, especialmente cuando van encabezados por el artículo, no se refieren a entidades consabidas para el receptor (ibid., p. 38). (...) El rasgo central de las expresiones definidas no es el conocimiento previo del objeto por parte del receptor, sino la identificabilidad del referente, es decir, la presuposición de que el receptor puede construir una representación mental adecuada del mismo. Un SN definido transmite el supuesto de que el referente es identificable de forma unívoca, sin ambigüedad (ibid., p. 39, destaque nosso).

“La Ley” apresenta um referente possível de ser identificado de forma unívoca, sem ambigüedad: a lei promulgada em 9 de setembro de 1857 na Espanha, cujo artículo 88 estabelece a obrigatoriedade da Gramática nas escolas do território espanhol. Estamos diante de um sintagma que não se submete a nenhuma inflexão. Mas a passagem da determinação do sintagma "la ley” para a indeterminação de "uma lei” elidindo a citação da fonte - produz efeitos de sentido diferentes.

O sintagma definido fecha o contorno do referente, operação que auxilia ainda na compreensão dos sintagmas finais do recorte apresentado, no qual se afirma que a lei de 1857 declarou que a Gramática da RAE “[seria] texto obligatorio y único en las escuelas de enseñanza pública”. Pelo efeito da determinação no texto da RAE, produzido no começo de século XX na Espanha, também parece claro o conjunto delimitado pelo sintagma "las escuelas de enseñanza pública". No entanto, no texto de Nascentes para os alunos do Colégio Pedro II, o mesmo sintagma, produto de uma indeterminação anterior que não especifica o Estado em que essa lei foi promulgada, pareceria projetar um conjunto indefinido ou, em palavras de Pêcheux ([1988] 2008, p. 20) “profundamente opaco”.

A lei mencionada pelo autor, conhecida como "Ley Moyano" (primeira lei integral de educação da Espanha), concedia exclusividade à norma gramatical da RAE, declarando que tanto a Gramática como a Ortografia seriam as normas únicas e obrigatórias que deveriam ser ensinadas na emergente educação pública espanhola (Villa, 2015; Arnoux, 2014). Impunha-se, assim, “um texto único” que se, por um lado, mostrava o profundo vínculo da RAE com a estrutura do Estado espanhol - uniformizando os textos que iam circular no ensino público (Arnoux, 2014) -, por outro, tentava silenciar 
uma série de gramáticas que competiam com a da $\mathrm{RAE}^{120}$ e que, como afirma Villa (ibid., p. 114), haviam ganhado a aceitação do público e estavam tomando conta do mercado de livros escolares, quebrando a hegemonia da RAE nesse campo. O trabalho da autora enfatiza a complexidade política desse processo de estandardização (ibid. p. 107), complexidade que aparece neutralizada no texto de Nascentes como efeito do apagamento das condições de produção desse fragmento.

Mas ainda caberia perguntar: por que são feitas na Gramática referencias à criação da RAE, aos instrumentos linguísticos produzidos por essa instituição e à Lei Moyano (uma lei de educação espanhola) que dava exclusividade a esses instrumentos normativos, em uma obra dirigida aos alunos do Colégio Pedro II? Qual é a imagem construída pela voz que enuncia e que autor projeta? Qual é o destinatário desses sentidos mobilizados no texto introdutório?

Se não podemos definir exatamente a quem são dirigidas essas intervenções (seriam a principio os alunos que trabalhariam com a Gramática, mas são eles realmente?), sim podemos reconhecer que elas contribuem na construção da imagem de um autor que se mostra conhecedor do "mundo do espanhol” sobre o qual se debruça para produzir a Gramática, e que conhece também os debates e disputas envolvidos na produção de instrumentos linguísticos que vinham sendo elaborados desde o século XVIII (no caso da Academia) e desde metade do século XIX após a constituição dos novos Estados nacionais em América. Em síntese, um autor que se mostra como um conhecedor da historia (e da historia política) da língua e como um sujeito que sabe e, portanto, que ocupa uma posição de saber.

\subsubsection{Espanha e “os espanhóis”}

O segundo aspecto que detectamos para designar o enraizamento da Gramática em uma norma central é o lugar de destaque dado à Espanha como espaço geopolítico de referência com relação à língua. Nesse contexto, o primeiro aspecto que chama à atenção é o fato de, a despeito de começar a Introdução mencionando as relações com os países vizinhos e o decreto por meio do qual é incorporado o espanhol ao Colégio Pedro II (retribuindo um gesto do governo uruguaio), Nascentes feche nas fronteiras da Espanha os

\footnotetext{
${ }^{120}$ Essas gramáticas: Gramática de la lengua castellana según ahora se habla (Salvá, 1831) e Gramática de la lengua castellana destinada al uso de los americanos (Bello, 1847) (Villa, 2015) também são fontes consultadas e citadas por Nascentes na Gramática.
} 
contornos da língua. Isso fica claro quando o autor explica que, embora na Espanha existam “províncias onde o povo não fala espanhol” - o galego falado na Galícia, o vasconço das Províncias Bascas e o catalão e suas variantes da Catalunha, Valença e Baleares -, "o espanhol é a língua oficial de todo o reino” (Nascentes, 1934, p. 3-4). Naturaliza-se, assim, esse fechamento geográfico e político: há outras línguas na Espanha - mencionadas pelo próprio autor - e há outros Estados nacionais onde é falado o espanhol - também elencados por ele -, no entanto, a partir desse momento, as fronteiras que delimitam a língua que está sendo apresentada ao leitor são as fronteiras "de todo o reino”. Os países vizinhos da América do Sul (e o espanhol neles falado), argumento que dava sustento à justificativa da incorporação da língua no Colégio, são abafados e a língua passa a ser significada, preferentemente, a partir de uma matriz colonial.

No interior do livro também há momentos que podemos identificar como de fechamento da fronteira da língua, quando o sujeito do discurso se refere aos espanhóis para abordar uma questão gramatical que tem um funcionamento mais geral no universo hispano-falante. Um exemplo disso ocorre no Capítulo XIX - "Sintaxe do artigo, do substantivo e do adjectivo”. Após explicar os diversos funcionamentos do artigo neutro, Nascentes acrescenta: “os espanhóis teem orgulho desta forma neutra do artigo que nas outras línguas românicas não existe ${ }^{121}$ [...]” (Nascentes, 1934, p. 86, itálico nosso). A presença desse gentílico que vincula a língua a um espaço específico está também no Capítulo XX - “Syntaxe do pronome”, no qual, inicialmente, o autor aborda a problemática das orações impessoais transitivas e intransitivas e das orações passivas para, a continuação, abordar as "reflexivas indirectas". Em palavras de Nascentes:

os espanhóis usam mais do que nós as orações que chamam reflexivas indirectas, isto é, em que o objecto indirecto é o próprio sujeito: Juan se bebe un tonel de vino. Aliás o caso mais parece de dativo de interesse (dativus commodi)" (ibid., p. 91).

No entanto, o uso das orações reflexivas indiretas não seria uma particularidade "dos espanhóis”, mas um uso mais estendido ao mundo hispânico. Vemos assim que em diversos recortes naturaliza-se o lugar dado à Espanha e aos espanhóis como espaço e sujeitos de referência. Propomos recuperar uma marca desse processo de naturalização, que irrompe quando o autor explica a designação do título da obra que ao invés de Gramática Espanhola poderia ter sido Gramática Castelhana, estruturando a argumentação em diferentes etapas e começando da seguinte forma:

\footnotetext{
${ }^{121} \mathrm{O}$ autor faz uma aclaração em nota dizendo: “existe no catalão, por influência espanhola”.
} 
A língua espanhola também é chamada castelhana, porque, "havendo Castela, diz a Academia, contribuido de modo preponderante na formação da nação espanhola, logrou que sua língua prevalecesse sobre os dialetos afins que se falam nos antigos reinos de Leão, Aragão e Navarra, e fez que se propagasse pela conquista à Andaluzia, à Murcia e à Extremadura” (Nascentes, 1934, p. 5).

Nessa primeira argumentação, pareceria haver uma relação de equivalência entre as duas designações: “a língua espanhola também é chamada de castelhana”, no entanto é na explicação introduzida por "porque” (atribuída à Academia) que a construção política da língua (Del Valle et al. 2015) - e de sua designação - e os discursos sobre o lugar central do dialeto de Castela na formação da nação, mostram-se e se fazem ouvir. Castela contribuiu "de modo preponderante na formação da nação espanhola”, diz o autor, impondo-se sobre "os dialetos” e se propagando com a conquista "logrou que sua língua prevalecesse sobre os dialetos afins que se falam nos antigos reinos de Leão, Aragão e Navarra” (p. 5). Para concluir a explicação, há uma exemplificação:

Desta denominação de castelhana há exemplos desde o século XIII; alguns autores clássicos e gramáticos repeliram-na por inexacta (PIDAL). Não obstante, a Academia, embora empregue ambas, a prefere (ibid.).

Convocando novamente a autoridade da Academia, o autor dá uma explicação que pareceria apoiar a denominação “castelhana”, num sentido contrário à designação dada por ele no título da obra (“língua espanhola”). É no final dessa explicação, no último parágrafo da Introdução, onde é apresentada a justificativa da escolha:

No estrangeiro foi sempre geral a denominação de espanhola (PIDAL) e a razão é fácil: no estrangeiro apagam-se as divergências dialetais para só considerar a língua da Espanha. Eis porque, a exemplo de muitos autores ${ }^{122}$, denominamos nosso livro “Gramática Espanhola” e não "Gramática Castelhana” (ibid. p. 5).

A que "estrangeiro" se refere Nascentes, poderíamos perguntar como leitores diante da primeira aparição do significante ("no estrangeiro foi sempre geral a denominação de espanhola”)? Como havíamos anunciado, naturaliza-se o fechamento do contorno da língua ao interior das fronteiras da Espanha, mas é o movimento que ultrapassa essas fronteiras o que justifica a designação do autor: "no estrangeiro apagam-se as divergências dialetais para só considerar a língua da Espanha”. As observações de Asencio (2009) ajudam a compreender as passagens da Introdução apresentadas acima com relação ao nome da língua. O autor explica que até 1920 as gramáticas da Academia se chamavam Gramática de la lengua castellana.

\footnotetext{
${ }^{122}$ Há aqui uma das poucas diferenças com a $1^{a}$ versão. Em vez de "muitos autores”, o autor lista uma série de gramáticos e hispanistas "estrangeiros": Chalumeau de Verneuil, Gorra, Paiva, Gottfried Baist, Adolf Zauner.
} 
Diferentemente, os gramáticos que publicavam no estrangeiro (isto é, fora da Espanha) desde o século XVI preferiam de modo geral chamá-la Gramática de la lengua española. Asencio parte das preferências da Academia para os títulos dados às gramáticas por ela produzidas, ficando claro, nessa situação, o alcance do significante “estrangeiro”, clareza que fica escura no processo de naturalização no qual interpretamos que se inscreve a obra de Nascentes. Nessa textualidade ficam expostas as contradições sobre as quais o autor justifica o título da obra, legitimando um sistema normativo centralizado que, originado em operações de inclusão e exclusão, naturaliza a norma do centro-norte da Espanha.

Amado Alonso, uma das principais figuras no campo da linguística hispânica, também auxilia na compreensão das explicações dadas na Introdução da Gramática de Nascentes para a designação da obra e para o sentido dado ao sintagma “estrangeiro”. No livro Castellano, español, idioma nacional ([1943] 1979), o autor faz um levantamento de obras escritas ou traduzidas desde o século XVI por espanhóis que se encontravam fora da Espanha (no estrangeiro). Esse levantamento o leva a afirmar que

En el extranjero, en medio de lo no español, se impone más claramente la visión de España como entidad unitaria y la del idioma como instrumento nacional (Alonso, [1943] 1979, p. 20).

Um pouco adiante, o próprio autor afirma que esses espanhóis que vivem no estrangeiro “dejan el habitual y heredado nombre de castellano para emplear el nuevo de español ${ }^{123}$, porque éste hacía referencia explícita a la perspectiva nacional e internacional que del idioma tenían” (ibid., p. 24). Além dos espanhóis, havia uma perspectiva análoga em escritores estrangeiros que afianzara a designação, levando Alonso a afirmar que "por española, sin duda, y no por castellana, se hizo lengua universal: el instrumento de comunicación del Imperio, de su administración, de sus conquistadores y navegantes, el habla que España trasplanta al Nuevo Mundo” (ibid. p. 36). O sintagma estrangeiro poderia apresentar esses dois sentidos expostos acima, ambos fortalecendo a designação de “língua espanhola” adotada por Nascentes.

A Gramática faz parte das obras iniciais de Nascentes. Como já se disse, no Brasil daqueles anos estava em curso uma etapa importante do processo de gramatização brasileira do português, um movimento que se por um lado argumenta a

\footnotetext{
123 Antes disso, o autor explica o surgimento do neologismo "español” para designar a língua (antes “castellana”), e o convívio de ambos os vocábulos. A nova designação respondia a uma também nova consciência de nacionalidade. Em palavras do autor: "El nuevo sentido estaba engranado con la visión de la magna entidad nacional, también nueva, `el idioma de la nación` era este sentido, y, como ya le venía pequeño el nombre de castellano, se puso en circulación el de español para expresarlo con más justeza” (ibid., p. 18).
} 
favor de um rompimento com a tradição gramatical portuguesa, também deixa entrever o litígio com discursos puristas que tomam o modelo português como parâmetro (Guimarães, 2004). A disputa entre língua central e variedades periféricas estava instalada no imaginário de época, no Brasil, e é em meio ao confronto desses discursos que o autor forma suas matrizes linguísticas e gramaticais. Com relação à língua portuguesa, nas seções anteriores, as análises nos permitiram apresentar a visão histórica e social do processo linguístico, o reconhecimento de falares, de dialetos e uma variante brasileira do português, a partir das afirmações do autor em diversos escritos. Com relação ao espanhol, a opção feita não só para a designação da obra e para as explicações em favor dessa designação, mas também com relação à Gramática da Academia (a autoridade legitimadora) deixa entrever a centralidade da matriz linguística assumida (ou anunciada) e uma relação estreita com o discurso dominante. No entanto, como apresentamos a continuação, mesmo com o pouco espaço e as poucas ferramentas para expandir a fronteira e a concepção da língua, o autor apresenta outros falares e a identificação com certas controvérsias.

\subsection{Outros dizeres e controvérsias}

Embora o autor anuncie, já na Introdução, uma obra vinculada à “autoridade soberana” da Academia e à Gramática produzida por essa instituição, também se pode afirmar que vai atravessando essa matriz de sentidos com outros dizeres que lhe permitem construir uma posição “mais ampla” com relação à língua. Surgem assim certos vaivens que nos permitem afirmar que se, por um lado, existe um processo que recorta e estabiliza determinados saberes - inclusive por uma questão quantitativa na frequência de citações que estabelece uma hierarquia no agenciamento das vozes presentes no texto -, também é verdade que, mesmo que esporadicamente, são apresentados aspectos da diversidade da língua e pinceladas em que a língua é mostrada como um objeto sobre o qual existem controvérsias e diferentes posições.

Já na Introdução o autor apresenta uma sensibilidade que olha para a diversidade social do mundo hispânico, apontando múltiplas situações de fala que incluem setores mais marginalizados. Ao enumerar onde e por quem essa língua é falada, se diz:

Na Europa, além de falada na Espanha, também é nos Balcans pelos judeus espanhóis expulsos da pátria no século $X V$. Na África é falado pelos judeus marroquinos e nos presídios e possessões espanholas (Tanger, Ceuta, Melilla, Rio do Ouro, Ilhas Canárias, Ilhas de Fernando Pó, Elobey e Ano BM, Corisco, 
Guiné Espanhola). Na América, em todos os países da Sul América, excepto o nosso Brasil e as Guianas, na América Central, no México, em Cuba, em Porto Rico, em São Domingos, em alguns Estados na União Americana (Arizona, Florida, Texas, Novo México, Baixa Califórnia, Colorado). Na Oceania, nas Filipinas, Carolinas e Palaos (Nascentes, 1934, p. 3).

O recorte aponta para uma consciência por parte do autor sobre os espaços mais marginais onde a língua era falada. No interior do livro, diversos fragmentos apresentam o funcionamento diverso da língua, especialmente no capítulo referido à pronúncia das letras.

Ao se referir ao som do "Ill” e do “y”, apresenta a fala da região do "Prata”. Com relação à primeira letra, afirma que “o ll tem o som de lh português. No Prata soa como o nosso j” (ibid., p. 9) e para se referir ao “y” diz: “o y, inicial ou médio, no Prata soa como nosso j” (ibid., p. 10).

Para abordar o som da letra "v", traz as variedades presentes em diferentes regiões da Espanha. Segundo o texto: “o v na maior parte da Espanha tem pronúncia igual à do b (ACADEMIA). Em bôca de catalães e valencianos o v espanhol soa como o v português” (ibid.). Embora de forma rápida, o autor ilumina espaços onde a língua vai apresentando variações.

No Capítulo IX - “Graus de significação”, encontramos as particularidades da língua em diferentes regiões da Espanha: “O sufixo in é mais asturiano que castelhano: calcetín; o sufixo ino é próprio da Extremadura: palomino; o sufixo iño da Galicia (port. inho): corpiño” (ibid. p. 37).

Também apresenta um aspecto da língua no espaço chileno. No Capítulo XV “Conjunções coordenativas”, numa das explicações, registra-se: “A conjunção y se transforma em $e$ diante de palavras começada por i ou por hi que não faça parte do diptongo [...]. No Chile se escreve i em lugar de y” (ibid. p. 74). Essa observação do autor nos faz realizar indagações que entram em relação com outras já formuladas: qual é a importância dessa observação sobre esse detalhe do funcionamento da língua, nesse livro específico e para esses alunos específicos? Seria uma observação alinhada a outras que, mesmo sem muita importância acabam apresentado uma língua que varia segundo as regiões? Seria mais uma observação que vai construindo e forjando a imagem de um autor conhecedor dessas especificidades da língua e da sua historia? ${ }^{124}$.

\footnotetext{
${ }^{124}$ Vale salientar que o uso apresentado pelo autor fez parte da Reforma ortográfica, aprovada em 1843 pela Universidade do Chile. A Reforma tinha sido proposta por Domingo F. Sarmiento e apoiada no início pelo reitor da universidade nacional chilena, o venezuelano Andrés Bello (Fanjul, 2011). Como afirmamos no capítulo anterior, essa reforma propunha algumas substituições ortográficas buscando facilitar a aprendizagem da língua. Com relação à observação realizada na Gramática de Nascentes, Asencio (2004, p. 222), citando palavras de Niño-Murcia (1997), assinala que o texto da Reforma
} 
Se, como acabamos de apresentar, diversos recortes permitem identificar, mesmo que de forma tênue, a presença de certas especificidades da língua nas diferentes regiões do mundo hispanofalante, também detectamos outros que funcionam como indícios de um estudioso que entende a construção do saber sobre a língua ora como um campo de controvérsias (no qual existem diferentes posições), ora de coincidências (em que diferentes autores assumem uma mesma posição), ora de complementações.

Ao abordar os barbarismos e solecismos, o autor deixa entrever diferentes posições, como se lê na seguinte afirmação:

Resta-nos falar da locução apenas si, muito encontrada em Martínez de la Rosa e aconselhada por Bello apesar de considerar tomada do francês. Essa locução se acha em bons escritores: Apenas si se hablaron ya hasta volver a casa (Valera); a Academia não a consigna nem na Gramática nem no Dicionário (ibid., p. 110).

Embora a locução não seja abordada pelos instrumentos linguísticos produzidos pela Academia, o autor faz questão de mostrar que existem outros gramáticos, como o “ilustre” Bello que a aconselham e a utilizam.

Também no uso do auxiliar, apresenta-se a tensão entre a prescrição e o uso culto:

O auxiliar castelhano da conjunção ativa é haber; o uso de tener é considerado um barbarismo, um lusitanismo (Cuervo), do qual, aliás há exemplos em Cervantes, Santa Teresa, Lope de Vega, Frei Luiz de Granada (ibid., p. 97).

O autor apresenta o uso normativo, neste caso conforme Cuervo e na sequência os grandes escritores que, apesar do caráter prescritivo da norma, utilizam o auxiliar tener. Existe a prescrição, mas, como vemos, também existe o uso transgressor, um uso culto que intercepta a norma e que o autor faz questão de mostrar.

Outro exemplo próximo ao anterior, em que a literatura culta não se deixa afetar pela prescrição da norma, surge na seguinte afirmação em meio às explicações dadas para os usos do gerúndio: “O emprego com o predicativo ou com o objecto indirecto a Academia considera incorrecto apesar de exemplos de Cervantes, Espronceda, etc.” (ibid., p. 99). Os casos aqui trazidos apresentam as tensões entre a prescrição e a literatura culta que a subverte.

Mas, como afirmamos, existem outros casos que abordam a língua como campo de coincidências. Um deles aparece após uma serie de explicações sobre o gerúndio e uma afirmação final do autor em que diz: "Por isso Bello, Salvá, Cuervo e a Academia censuram a frase: te envío una caja conteniendo libros; Salvá acoima de galicismos e a

propunha "reemplazar la (y) como conjunción con la (i) de manera que la (y) se reservaba para usos consonánticos". O texto de Niño-Murcia citado por Asencio é "Ideología lingüística hispanoamericana en el siglo XIX: Chile (1840-1880)". Hispanic Linguistics 9.1. 100-142. 
Academia manda dizer con libros ou que contiene libros” (ibid. p. 99). Como vemos, não é só a Academia quem censura usos, mas gramáticos do peso de Bello, Salvá e Cuervo.

Finalmente, é possível achar recortes que indicam que, por vezes, o autor vê nas vozes citadas complementações que lhe permitem ampliar a fronteira da regulação proveniente da Gramática da RAE. É o caso seguinte, tomado do capítulo em que são abordados os barbarismos e solecismos. Em primeiro lugar, como apresentamos acima, o autor apresenta a série recortada da Gramática da RAE de 1917, para depois afirmar: “Além dêstes, apontados pela Academia, vejamos outros indicados por Bello” (ibid., p. 109). A continuação, Nascentes assinala uma série de exemplos dados por esse autor que complementariam os apresentados a partir da Gramática da RAE ${ }^{125}$. Um segundo caso, também de controvérsia, pode ser encontrado quando na Gramática de Nascentes se aborda, no Capítulo XXI - "Sintaxe do verbo”, o uso dos particípios e, especialmente, aqueles que apresentam duas formas. Nos pares prendido e preso, proveído e provisto, rompido e roto, apresentam-se com exemplos as preferências de Salvá e as de Bello para os pares de particípios mencionados (ibid., p. 100).

As vezes, sem dar referências específicas, o autor indica, mesmo que de forma bastante indeterminada, o uso variado da língua. No capítulo XXIII “Arcaismos e Neologismos”, apresenta o estudo dividido nos diferentes estratos: fonéticos, morfológicos, de léxico, sintácticos, gráficos. Após essa apresentação, afirma que “muitos arcaismos se conservam vivos na linguagem dos povos hispano-americanos” (ibid., p. 107).

Nascentes afirma que “o léxico espanhol, que é tão parecido com o português na forma das palavras, também o é na significação” (ibid., p. 114). Comparando as palavras na forma e no sentido, no capítulo XXVIII “Noções de semântica”, o autor faz um estudo mais específico, passando por aquelas que têm a mesma significação ("homônimos homossemânticos”) e significação diversa ("homônimos heterossemânticos”) ${ }^{126}$. Assim como para os "heterônimos” (as "palavras diferentíssimas na forma”) o autor afirma que “só o dicionário ou a prática poderão explicar a significação” (ibid., p. 115). Mas é na parte prática dessa terceira edição, dividida em 32 lições, onde são abordadas formas lexicais específicas, com indicações de uso em diferentes países. Nessa seção o autor vai

\footnotetext{
${ }^{125}$ Alguns dos indicados por Bello são: "o uso de primero, postrero e último, regendo infinito com a preposição en: primero en apresentarse; o verbo ser seguido de que: a la libertad de la tribuna es que se debe atribuirse, allí fue que se edifico la ciudad; o uso do adjectivo possessivo em vez de pronome pessoal oblíquo: sus ojos se llenaron de lágrimas (sés yeux se remplirent de larmes) en vez de se le llenaron los ojos de lágrimas” (Nascentes, 1934, p. 109-110), dentre outros.

${ }^{126}$ Funda-se nessas designações uma maneira de ver a língua e se referir a ela que permanecerá até os dias atuais.
} 
apresentando diferenças de léxico por meio de uma lista que seria de uso geral e algumas formas específicas no dizer de um país. Vale observar que uma alta freqüência dessas formas específicas é da Argentina. Por exemplo: a lição que aborda os animais: "benteveo o bichofeo (Argentina)”, “alondra, hornero, pinzón, corneja, chingolo (Argentina)”, “Insectos: abejorro, escarabajo, luciérnaga, cucaracha (barata en Chile)” (ibid., p. 130).

O começo do século XX está marcado no Brasil pelas disputas em torno à língua nacional. Época de formação e das primeiras produções do autor da Gramática de espanhol elaborada especialmente para ensinar a língua no Colégio Pedro II, essas tensões marcam as ideias linguísticas na produção de Nascentes. Neste capítulo tentamos mostrar que, sem abandonar as ideias do que podemos reconhecer como discurso dominante na área dos estudos linguísticos, o autor vai expandido suas concepções e reconhecendo características particulares do português "transplantado ao Brasil”. Essa expansão que o autor faz a partir das ideias dominantes nesse campo de conhecimento, também pode ser identificada na Gramática de espanhol, uma obra que inaugura uma memória sobre o processo de gramatização do espanhol em Brasil e inaugura o que é quase um século de presença - por momentos dominante - de uma matriz ideológica, discursiva e cultural peninsular. Naquela época, os instrumentos linguísticos da RAE eram fontes bastante hegemônicas na produção de outros instrumentos linguísticos para o ensino de espanhol como língua estrangeira em diversos países. Essa hegemonia também está presente na Gramática, embora em diversos momentos esteja também presente a visão do autor sobre a diversidade linguísticas e as transformações pelas que passam as línguas, especialmente as "transplantadas”. A análise fica mais complexa quando se cruza a historia, a formação intelectual e a atuação profissional de um autor, com as disputas e hegemonias de um campo científico específico. Se a memória do processo de gramatização do espanhol em Brasil se inicia com essa forte marca de uma matriz discursiva peninsular, também é verdade que existem outras marcas (que também participarão da construção de uma memória sobre a língua) que, embora timidamente, abrem uma fissura nesse discurso hegemônico e apresentam indícios da historia e da formação intelectual desse autor negro que entendia as transformações linguísticas e as independências políticas estreitamente vinculadas. 


\section{CAPÍTULO 3}

A entrada do espanhol no currículo na Era Vargas e a expansão do mercado editorial 
Esta segunda parte do trabalho se propõe discutir, por um lado, o processo de reestruturação da educação que leva a obrigatoriedade da língua espanhola ao ensino secundário, com a chamada Reforma Capanema, e por outro, a aceleração na produção de instrumentos linguísticos, como efeito desse gesto da política linguística, em especial, buscando compreender a produção do Manual de Español, de Idel Becker (1945) em meio a essa expansão editorial.

O objetivo mais amplo é dar continuidade às reflexões iniciadas no núcleo anterior, indagando sobre como as condições de produção desse processo de transformação do país, da sociedade e do sistema educativo operam nos processos de produção de sentido (Pêcheux, [1969] 1990), especialmente na elaboração do Manual de Espanhol, que marcou por quase meio século a história do ensino da língua no Brasil.

A Reforma Capanema e a consequente aceleração na produção de instrumentos linguísticos para o ensino da língua se desenvolvem no contexto da Era Vargas (19301945) que marca uma etapa da história do Brasil com um forte viés nacionalista. A entrada do espanhol no currículo acontece, mais especificamente, durante a fase conhecida como Estado Novo (1937-1945) ${ }^{127}$, período em que ocorre uma centralização político-administrativa - por meio do sistema de interventorias (Al Assal, 2013) - e no qual Getúlio Vargas impôs a censura aos meios de comunicação e perseguiu seus inimigos políticos (Napolitano, 2017). Entretanto, mesmo que com restrições no terreno da cidadania civil e política, “o Brasil experimentou políticas públicas que o tornaram mais moderno economicamente e menos excludente socialmente, embora não menos desigual” (Gomes, 2005, p. 106). Ressalta-se assim o caráter complexo e ambíguo da experiência vivida nesses anos e o desenho de uma outra "arquitetura institucional de Estado, de fundo antiliberal e intervencionista” (ibid. p. 108) ${ }^{128}$. Nesse contexto, os trabalhadores teriam pela primeira vez certos direitos sociais garantidos por lei.

\footnotetext{
${ }^{127}$ Segundo Oliveira (2001, p. 47), o Estado é novo “na medida em que procura modernizar o país” e é novo "porque pela primeira vez se apresenta voltado para as verdadeiras raízes da nacionalidade".

${ }^{128}$ Ver também Gomes (2014). Na mesma direção, Paul Singer (1984, p. 218) manifesta que após 1930, a grande mudança foi a prioridade máxima que o poder deu ao desenvolvimento do mercado interno, "ao crescimento para dentro, adotando uma estratégia em que a industrialização aparece como instrumento para tornar a economia nacional o menos dependente possível do mercado mundial”.
} 
Desenhava-se uma nova forma de Estado marcado pela centralização política em torno da figura do presidente (Payer, 2006). Uma centralização que, segundo Fausto (2015), o distinguia do Estado oligárquico das décadas anteriores e se caracterizava por uma irradiação do poder do centro para a periferia (e não ao contrário) e pela própria perda de terreno do poder de tipo oligárquico que estava baseado na força de cada um dos Estados do país. O historiador afirma que esse novo Estado regulador buscava promover a industrialização e que o crescente interesse por tal promoção, a partir de 1937, também teve efeitos no campo educacional, levando a organizar o ensino industrial $^{129}$. Para Schwartzman, Bormeny e Costa (1984, p. 18), o que houve foi um processo de modernização conservadora.

Sobre a dimensão econômica, vários estudiosos coincidem no reconhecimento de que até a segunda guerra os principais parceiros comerciais foram os Estados Unidos e a Alemanha. Cervo (2003) observa que os anos entre 1930-1940, posteriores à crise de 29, marcam no Brasil - e em outros países da região - uma etapa desenvolvimentista, com um modelo de inserção internacional. Devido às relações que o Brasil mantinha com esses dois eixos de poder em ascensão, a política exterior desses anos foi apontada como de “jogo duplo”. Para Napolitano (2017), a geopolítica brasileira dos anos 1930 foi marcada, em grande parte, pelos interesses desses dois países. Esse equilíbrio foi rompido em agosto de 1942 com a declaração da guerra ao eixo. O Brasil finalmente tinha tomado uma posição com relação à guerra, ficando os Estados Unidos como o principal parceiro comercial $\left(\mathrm{Cpdoc}^{130}\right.$, s/d). Desse país obteve algumas vantagens econômicas como a construção da usina siderúrgica de Volta Redonda, financiada por ele (Napolitano, 2017) ${ }^{131}$. Em todo esse contexto também acontecem nessa década importantes tratados comerciais com os países vizinhos.

\footnotetext{
${ }^{129}$ É de 1942 a criação do Serviço Nacional de Aprendizagem Industrial (SENAI), uma entidade que surge para dar assistência ao trabalhador e formar rapidamente operários qualificados para a indústria, preparando-os para funções mais especializadas (Al Assal, 2013).

${ }^{130}$ CPDOC: Centro de Pesquisa e Documentação de Historia Contemporânea do Brasil, Fundação Getúlio Vargas.

${ }^{131}$ No mesmo trabalho, o historiador chama a atenção para a complexidade das relações com os Estados Unidos e para a penetração da influência cultural e econômica da potência do norte em território brasileiro, suplantando a tradicional presença de franceses e ingleses nessas respectivas áreas. Se a siderúrgica de Volta Redonda responderia a essas mudanças, também seria mostra disso a chegada em 1942 da Coca-Cola - símbolo máximo do capitalismo norte-americano - e, ainda antes, em 1940, a criação da chamada Office of the Coordinator of Inter-American Affairs, uma agência de coordenação de programas de colaboração entre as potências do norte e os países latino-americanos (ibid., p. 125 e 129). Tudo isso dentro do marco da "Política de Boa Vizinhança", desenvolvida pela elite política e econômica norte-americana para se aproximar de brasileiros e latino-americanos em geral, buscando evitar a contaminação das elites políticas pelas ideias nazifascistas (ibid. p. 129).
} 
No mesmo sentido de modernização e desenvolvimento econômico, de construção de políticas públicas e de organização do Estado, e de um “desejo” governamental de maior aproximação e vinculação com os países da região ${ }^{132}$ (anseios que retomaremos adiante), também no setor educativo haveria mudanças no sentido de elaborar um projeto de educação para o país. A instauração da obrigatoriedade da língua espanhola nas escolas secundárias do Brasil acontece como efeito do Decreto Lei 4.244 (1942), conhecido também como Lei Orgânica do Ensino Secundário, ou Reforma Capanema ${ }^{133}$. Uma reforma do ensino secundário que se caracterizaria "pela intenção de consolidar a escola secundária como principal instituição educacional e, através dela, formar novas mentalidades, criar uma cultura nacional comum e disciplinar as gerações para garantir a continuidade da pátria”"134 (Schwartzman, Bormeny e Costa, 1984, p. 202).

A Reforma Capanema - dando continuidade à de Francisco Campos (1931), e à Constituição de 1934 - propunha um projeto educativo nacional, ausente na década de 1920. Schwartzman, Bormeny e Costa (1984, p. 49) assinalam que segundo o artigo 150 da Constituição de 1934, “caberia à união fixar o Plano Nacional de Educação ${ }^{135}$ para todos os graus e ramos de ensino, comuns e especializados”. Também caberia “a coordenação e fiscalização da execução do plano em todo o território do país; e a organização do ensino secundário e superior nos territórios e no Distrito Federal” (ibid.). Nesse sentido, a Constituição de 1934 é um marco: foi a primeira vez "que o Estado assumiu a responsabilidade de traçar as diretrizes de todos os graus e ramos, comuns e especializados, coordenando e fiscalizando sua execução em todo o território nacional”136 (Ferreira, 2008, p. 25).

\footnotetext{
${ }^{132}$ Esse movimento de aproximação aos países da região - sobre o qual trabalharemos ao longo do capítulo - se faz visível em diversos âmbitos do acionar político do governo: por um lado, nos documentos que propõem e anunciam a incorporação da língua no currículo escolar, também na firma de tratados comerciais com os países da América Latina (as relações econômicas e comerciais propiciavam essa aproximação) e, além disso, na proposta e efetivação de levar adiante uma missão cultural nos países vizinhos.

${ }^{133}$ A Reforma Capanema foi proposta por Gustavo Capanema que ocupou o Ministério de Educação e Saúde de 1934 a 1945 (Fausto, Devoto, 2004) e consagra a divisão entre o ginásio (que passaria a ter 4 anos e não cinco) e um segundo ciclo de 3 anos, com a opção entre o que se chamou de clássico e científico.

${ }^{134}$ A reforma estabeleceu a obrigatoriedade da frequência à escola secundária.

135 Segundo Schwartzman, Bormeny e Costa (1984, p. 182), o Plano Nacional de Educação foi encaminhado em 1937. O documento buscava consagrar uma série de princípios, normas e opções educacionais que não eram consensuais. Vale lembrar as tensões entre o movimento da Escola Nova e a Igreja Católica (que controlava quase que a totalidade das escolas privadas do país) que via com receio a subordinação da educação ao Estado. Os católicos próximos ao governo, como Alceu Amoroso Lima, pressionavam para que a educação moral e cívica fosse realizada através do ensino religioso. Al Assal (2013) assinala que é importante compreender o Estado Novo como um cenário com contradições inerentes, de acomodação de pluralidades para a construção da unidade nacional.

${ }^{136}$ Para compreender a centralização do Estado é importante fazer uma comparação com a Constituição anterior, de 1891, que regeu o país até 1934. Nessa constituição dava-se aos Estados grande autonomia,
} 
No entanto, cabe indagar: Quais são as mudanças que, no plano educativo, nos permitem falar em reformas, em novos paradigmas e representações? Candido (2011, p. 220) afirma: "não foi o movimento revolucionário de 1930 que começou as reformas [educativas], mas ele propiciou a sua extensão por todo o país”, projetando na escala nacional (ao igual que com a cultura) fatos que antes ocorreram no âmbito das regiões. O próprio Candido (ibid. p. 219) se refere a outro aspecto importante: “o surgimento de condições para realizar, difundir e "normalizar" uma série de aspirações, inovações, pressentimentos gerados no decênio de 1920, que tinha sido uma sementeira de grandes mudanças”. Essas reformas locais, ocorridas na década anterior, tinham se iniciado em 1920, em São Paulo, com a reforma de Sampaio Dória que buscou modernizar os métodos pedagógicos e procurou tornar realidade o ensino primário obrigatório incrementando as escolas rurais. Também foram importantes as reformas de Lourenço Filho no Ceará (1924); a de Francisco Campos em Minas (1927) e a de Fernando de Azevedo no Distrito Federal (1928). Segundo Candido, todas elas "visavam a renovação pedagógica expressa na designação de "Escola Nova”, que representava posição avançada no liberalismo educacional” (ibid. p. 221) e que viria a ter uma atuação importante no governo Vargas. Educadores ligados ao movimento da Escola Nova começaram a trabalhar para o governo, como uma forma de legitimar e intervir com suas ideias nesse projeto nacional de educação (Sampaio, 2010) e de tentar inovar em termos educativos ${ }^{137}$.

Os números indicam o esforço por expandir um sistema escolar que nos anos 1920 contava com um índice de analfabetos de quase 70\% (Fausto, 2015). Em aqueles anos os “meninos e meninas entre 5 a 19 anos que freqüentavam a escola primária ou média era de cerca de 9\%”, tendo chegado, em 1940, a pouco mais de $21 \%$ (ibid., p. 217). “As esperanças postas na Educação eram enormes”, comentam Schwartzman, Bormeny e Costa (1984, p. 17). A educação se expandiu, embora não atingisse o horizonte que as ideias em jogo e um projeto nacional de educação pareciam potencializar ${ }^{138}$.

inclusive, como afirma Ferreira (2008, p. 25), "para que criassem instituições de ensino superior e secundário, além de poderem legislar sobre a educação primária e profissional”.

${ }^{137}$ Os educadores vinculados à Escola Nova lançaram em 1932 o Manifesto dos Pioneiros da Escola Nova. Segundo Napolitano (2017, p. 147), nele se defendia "de maneira contundente, uma escola pública, gratuita e laica, com métodos de ensino mais modernos e estimulantes do que a velha técnica de repetição e memorização". Ainda segundo a perspectiva do historiador, essa escola deveria ser "um elemento de democratização da sociedade, ajudando a superar as diferenças socioeconômicas de origem” (ibid., p. 148). ${ }^{138}$ As reformas educativas argumentavam em favor da modernização do país, no entanto, Rodrigues (2012, p. 68-73) assinala, a partir do trabalho de Zotti (2006) e de Payer (2006), que a Reforma Capanema (1942) não interrompeu a tradição predominante na educação que continuava estando ao serviço dos interesses da elite, tanto ao pensarmos na presença e distribuição curricular das línguas estrangeiras, quanto na supervalorização do português enquanto língua nacional. Essa supervalorização 
A maior crítica feita ao regime varguista no aspecto educativo foi a de não ter encampado a expansão da escola primária. Isso entra em relação com o que Candido (2011) designa como "ampla reforma", negando que haja havido uma "revolução educacional”, observação que o leva a abordar as diferenças, como podemos ver no seguinte fragmento:

\begin{abstract}
As reformas na educação não geram mudanças essenciais na sociedade, porque não modificam a sua estrutura e o saber continua mais ou menos como privilégio. São as revoluções verdadeiras que possibilitam as reformas do ensino em profundidade, de maneira a torná-la acessível a todos, promovendo a igualitarização das oportunidades (ibid., p. 222).
\end{abstract}

Nesse sentido, nota-se que após a reforma, as oportunidades mais modestas, que corresponderiam à escolarização primária continuavam sendo irrisórias ${ }^{139}$. Candido esclarece que esse fato não acontecera nem com as escolas médias nem com o ensino técnico sistematizado, que tiveram um aumento significativo. E é justamente nesse âmbito educativo do ensino médio em expansão que a língua espanhola é incorporada ao currículo.

Levar isso em consideração é importante para a análise dos instrumentos linguísticos, já que nessa mudança de paradigma, não só a estrutura do sistema muda, mas mudam também, expandindo-se, os sentidos projetados para a educação. Já não se tratava apenas de formar intelectualmente a elite que continuaria seus estudos na Europa e voltaria para conduzir politicamente o país (como nos anos de 1920), mas de oferecer um ensino secundário que “deveria formar uma verdadeira 'consciência patriótica' própria de `homens portadores das concepções e atitudes espirituais que é preciso infundir nas massas, que é preciso tornar habituais entre o povo'”, como assinalam Schwartzman, Bormeny e Costa (1984, p. 194) ao abordar sequências do Plano Nacional de Educação. Observe-se que se fala em "massas" e se elabora um Plano que, entendemos, produziu efeitos, independentemente de pensarmos o verdadeiro alcance que isso possa ter tido. Por isso, na análise é relevante abordar as marcas que esse projeto de massificação e de formação de um "homem novo" deixa na produção de instrumentos linguísticos, inclusive nos elaborados para atender a demanda pela inclusão da língua espanhola na grade curricular da escola.

pode ser melhor compreendida ao pensarmos que o programa político do governo projetava uma Nação que devia ter uma língua única como elemento fundamental da sua construção.

${ }^{139}$ Segundo Londres (2001, p. 117), o fracasso de Gustavo Capanema com relação ao ensino primário se deveu, em parte "ao fato de que as próprias interventorias estaduais acabaram se opondo às intenções unificantes do regime, criando assim um impasse para o Estado autoritário na implantação de sua política para esse nível de ensino", fato que também apresenta as tensões que existiam dentro desse Estado. 
A permanência de Capanema no Ministério de Educação e Saúde (1934-1945) deu continuidade e estabilidade às políticas desenvolvidas pelo governo e permitiu delinear mudanças significativas. O Ministério foi se convertendo num dos principais pontos de apoio ao regime, tendo um papel decisivo para sinalizar a importância atribuída à cultura no novo modelo, no qual era um assunto de Estado (Schwarcz, Starling, 2015, p. 377) ${ }^{140}$. Isso também sinaliza uma diferença importante com os anos 1920, nos quais não havia a presença do Estado e sim a supremacia e poder das oligarquias regionais. Segundo Candido (2011), depois de 1930 teria se esboçado uma mentalidade mais democrática a respeito da cultura, e pelo menos em tese, esta começou a ser vista como direito de todos, contrastando com a visão aristocrática que predominara no Brasil até esse momento. Assim, por exemplo, se nos anos iniciais do Brasil republicano tinha havido um recrudescimento sobre as práticas de candomblé, sobre a capoeira, os batuques e sambas e sobre qualquer manifestação que se identificasse como “africana” (Fraga, 2018), a partir de 1937, a capoeira passaria a ser valorizada, ganhando por parte do Estado Novo o status de modalidade esportiva nacional, como o próprio candomblé, oficializado nesse mesmo contexto e autorizado a ser praticado (Schwarcz, Starling, 2015, p. 379).

Desse modo, pode-se compreender como cultura e educação seriam dois pilares importantes do governo Vargas, estratégias de construção de um "homem novo” para um "Estado Novo" que buscava construir os valores de "brasilidade" forjando "uma nação-povo integrada e blindada contra os regionalismos desagregadores da Primeira República” (Napolitano, 2017, p. 136).

Mas se houve transformações, também é verdade que continuaram em vigência aspectos da República Velha. Com relação às continuidades, Schwarcz e Starling (2015, p 367) assinalam algumas, dentre elas: a estrutura agrária que se conservou inalterada e que, segundo as autoras, manteve o trabalhador rural fora da legislação protetora do trabalho $^{141}$ bem como a exclusão dos analfabetos do processo eleitoral e ainda a restrição das garantias individuais dos imigrantes.

Se o nacionalismo existente levou à expansão do sistema educativo e da industrialização do país, também afetou outros aspectos da sociedade no Brasil, dentre

\footnotetext{
${ }^{140}$ Para Londres (2001, p. 101) “a gestão Capanema à frente do Ministério de Educação e Saúde teve o caráter de gesto fundador das relações entre Estado e cultura no Brasil, implantando um modelo não apenas institucional como também de relação entre poder público e intelectuais".

${ }^{141}$ Napolitano (2017, p. 122), em observação mais crítica, afirma que com relação aos trabalhadores rurais "o Estado no atuou para retirá-los do círculo de poder dos coronéis e da miséria secular a que estavam condenados”.
} 
eles a vida de algumas comunidades de imigrantes sobre as quais o Estado Novo desenvolveu uma política de vigilância e de nacionalização cultural. Diferentemente dos governos anteriores que tinham visto na imigração uma solução para o país e para o desenvolvimento da economia (especialmente após a libertação dos escravos), o governo Vargas encarou as regiões de colonização estrangeira e especialmente as colônias de imigrantes que mantinham costumes, tradições e língua próprias, como um problema nacional (Bueno, 2008). Assim, levou adiante um amplo projeto nacionalizador no qual a questão da língua era estratégica. Para Payer (2006, p. 30), nos anos 1930 “a questão nacional se colocou de modo vigoroso com relação à língua”. A partir do governo, afirmava-se que “o conhecimento seguro da própria língua constitui para uma nação, o primeiro elemento de organização e de conservação de sua cultura” (Brasil, 1942a, Exposição de Motivos da Reforma Capanema). Sendo a língua algo fundamental para a nação, o ensino do português foi ampliado "tornando-se obrigatório em todas as sete séries, com a mesma intensificação para todos os alunos” (ibid.).

Como observam Schwartzman, Bormeny e Costa (1984), a formação do Estado Nacional passaria necessariamente pela homogeneização da cultura, dos costumes, da língua e da ideologia. Para esse projeto, as escolas seriam verdadeiros pólos a partir dos quais irradiaria o ideário nacionalista, buscando fazer dos jovens "autênticos brasileiros”, por meio de uma cultura política na qual a formação moral respondesse aos interesses do Estado (Ferreira, 2008). Pretendia-se atingir de forma especial regiões mais isoladas que haviam recebido movimentos migratórios importantes, especialmente de imigrantes que falavam alemão e italiano (Campos, 2006). A política de vigilância e nacionalização cultural proibiu o ensino de alemão e italiano nas escolas comunitárias e religiosas do Sul do Brasil, que passaram a ser vistas com desconfiança, pois eram tidas como potenciais aliadas do exército alemão ${ }^{142}$ (Napolitano, 2017).

Mais do que indagar os quinze anos em que Vargas esteve no poder, apresentamos até aqui algumas questões relevantes, especialmente aquelas que de modo geral marcam uma mudança de paradigma, ou certas continuidades, com respeito ao período abordado anteriormente, seja no âmbito educativo ou no modo de se pensar um projeto de país. Buscamos mostrar que o que ocorria na área da educação e da cultura

\footnotetext{
${ }^{142} \mathrm{~A}$ despeito dessa proibição, como veremos adiante, as diretrizes da legislação educativa produzidas com a Reforma recomendavam a inclusão do alemão e do italiano como línguas optativas, pelo "valor cultural e a importância bibliográfica" e por constituir um elemento auxiliar de primeira necessidade para os estudos científicos e técnicos (Brasil, 1942a, Exposição de Motivos da Reforma Capanema).
} 
naqueles anos estava inserto em todo esse processo mais amplo de mudanças e transformações do país.

Nesse contexto, é importante compreender a entrada do espanhol no currículo e a produção de instrumentos linguísticos à luz dessa conjuntura histórica marcada pela proposta de um projeto nacional de padronização do sistema educativo, e no plano econômico, dentro do que Fausto (2015, p. 214) reconhece como a promoção de um capitalismo nacional sustentado pela ação do Estado.

Para abordar aspectos que integram a rede complexa de condições de produção, organizamos o capítulo em quatro seções. Na primeira, buscamos entender as orientações dos textos ministeriais, isto é, os sentidos projetados a partir do Estado na Exposição de Motivos da Reforma Capanema, na própria Reforma e na criação da Comissão Nacional do Livro Didático (1938). Na segunda seção, analisamos as diretrizes do Programa de Espanhol formulado a partir do Ministério de Educação e Saúde para ser aplicado no ensino secundário. Na terceira parte do capítulo, indagamos os efeitos dessa política linguística do Estado - a incorporação da língua ao currículo e a produção de um Programa específico para seu ensino na escola - na expansão do mercado editorial de livros de espanhol, buscando rastrear regularidades e diferenças dentro dessa ampla produção e justificar a escolha do Manual de Español, de Idel Becker (1945) como objeto de estudo por considerá-lo instrumento linguístico paradigmático de uma época. Finalmente, abordamos aspectos biográficos e da trajetória profissional do autor do Manual e rastreamos, em uma série de três obras escritas entre 1943 e 1945, as representações sobre a língua espanhola - objeto de gramatização - e sobre os destinatários.

\section{Exposição de Motivos e a Reforma Capanema: um programa político e um projeto nacional de educação}

A Exposição de Motivos da Reforma, um texto encaminhado por Gustavo Capanema em $1^{\circ}$ de abril de 1942 ao Presidente da República para submeter à consideração o projeto de lei orgânica do ensino secundário, apresenta, já de saída, considerações fundamentais que são importantes para compreendermos a mudança de rumo que o governo tentou imprimir ao projeto educativo logo após chegar ao poder na década de 1930. Na explicação inicial desse documento de 1942 são retomadas ações 
que tinham sido desenvolvidas nos primeiros anos de governo e que estavam vinculadas ao sistema vigente do ensino secundário que datava de 1931. O documento retoma explicitamente a Reforma Francisco Campos (1931) que dentre outros aspectos ampliou o ensino secundário de cinco a sete anos e "homogeneizou, de forma inédita, a cultura escolar do ensino secundário brasileiro, pois estabeleceu oficialmente procedimentos administrativos e didático-pedagógicos para todos os ginásios do território nacional” (Dallabrida, 2009, p. 185).

O documento dá destaque a uma política educativa de Estado e a um projeto educativo nacional iniciado uma década antes, anunciando que a lei projetada em 1942 encontrava “terreno amplo e condições favoráveis" para prosseguir o "trabalho de renovação e elevação do ensino secundário no país” (Brasil, 1942a, Exposição de Motivos). Anunciava-se uma mudança significativa com relação aos anos anteriores ao Estado varguista, afirmando que o sistema vigente desde 1931, trouxera a vantagem para a educação do país de uma concepção cuja base consistiria na afirmação “do caráter educativo do ensino secundário” (ibid.), estabelecendo assim uma contraposição com a prática reinante até aqueles anos em que esse âmbito de ensino era considerado um conjunto de preparatórios que funcionava como mero estudo de passagem para os cursos de ensino superior (ibid.).

Também se assinala que a legislação em vigor até aquele momento tinha facilitado a generalização do ensino secundário, antes ao alcance de poucos, nos diferentes pontos do país. Os números apresentados são significativos: em 1931 havia no Brasil menos de duzentas escolas secundárias, já em 1942, elas eram quase oitocentas. Assim, a lei de 1942 era promulgada após uma década marcada por uma proposta de expansão do ensino secundário.

Em outra parte do documento, afirma-se que a reforma atribui a tal ensino a faculdade fundamental de formação da personalidade adolescente (ibid.), fazendo a ressalva de que "formar a personalidade, adaptar o ser humano às exigências da sociedade, socializá-lo, constitui finalidade de toda espécie de educação” (ibid.) e registrando, a continuação, a especificidade desse ensino:

O que constitui o caráter específico do ensino secundário é a sua função de formar nos adolescentes uma sólida cultura geral, marcada pelo cultivo a um tempo das humanidades antigas e das humanidades modernas, e bem assim, de neles acentuar e elevar a consciência patriótica e a consciência humanística.

Este último traço definidor do ensino secundário é de uma decisiva importância nacional e humana (ibid., itálico nosso). 
Nesse contexto é que entrou o espanhol no currículo, numa malha de estabelecimentos educativos que em uma década (entre 1930 e 1940) praticamente tinha quadriplicado. Nessa rede estendida buscava-se "elevar [nos alunos] a consciência patriótica e a consciência humanística” e desenvolver neles uma "sólida cultura geral”, aspectos que deixariam suas marcas na produção de instrumentos linguísticos de modo geral, inclusive no Manual de Español de Idel Becker que analisaremos no próximo capítulo.

“Acentuar e elevar a consciência patriótica e a consciência humanística” era "de uma decisiva importância nacional e humana” (Brasil, 1942a). Ao mesmo tempo em que a consciência humanística implicava que os jovens compreendessem a importância do seu destino no mundo (“a compreensão do valor e do destino do homem”, “do que é o homem” e “uma concepção do ideal da vida humana”) ia se configurando um aspecto central que atravessava tanto a Exposição de Motivos como a própria Reforma: a formação patriótica dos adolescentes. No texto há marcas de que a autoria desse projeto tinha consciência de que esses estudantes iam conformar no futuro o aparelho estatal, participando nele:

É que o ensino secundário se destina à preparação das individualidades condutoras, isto é, dos homens que deverão assumir as responsabilidades maiores dentro da sociedade e da nação, dos homens portadores das concepções e atitudes espirituais que é preciso infundir nas massas, que é preciso tornar habituais entre o povo (Brasil, 1942a).

E formar os quadros políticos que integrariam futuramente o Estado não estava vinculado, como em outros momentos da historia do Brasil, unicamente a uma elite, como nos permite pensar o próximo recorte:

São estabelecidos preceitos destinados à diminuição do custo do ensino secundário e ao desenvolvimento da assistência aos escolares necessitados. A providência tem em mira proporcionar, o mais que for possível, a educação secundária aos adolescentes bem dotados (ibid.).

A classe dirigente não tinha que provir, necessariamente, das famílias pertencentes à burguesia, mas dos adolescentes que estivessem "bem dotados” para desenvolver essa função, e o Estado - que parecia requerer essas outras experiências e trajetórias - teria que dar as oportunidades para a participação de jovens vindos de outras classes sociais.

Reforçando essa questão, e marcando uma mudança significativa com relação à história próxima da jovem república, o art. 90 da Reforma Capanema expressa: 
Constitue obrigação dos estabelecimentos de ensino secundário, federais, equiparados e reconhecidos, reservar anualmente determinada porcentagem de lugares gratuitos e de contribuição reduzida para adolescentes necessitados. Essa porcentagem será fixada, em cada caso, mediante a aplicação de critério geral (Brasil, 1942b).

O Estado não só manifestava o interesse de uma participação mais ampla da sociedade, mas dava diretrizes para que isso pudesse ser materializado.

Tanto na Exposição de Motivos como na Reforma, reitera-se a série pátria/patriótico/patriotismo como modo de especificar (e de significar) fundamentalmente o objeto desse discurso: o ensino, seus fins, seus meios. Vejamos:

Ele [o ensino secundário] deve ser, por isto, um ensino patriótico por excelência, e patriótico no sentido mais amplo da palavra, isto é, um ensino capaz de dar aos adolescentes a compreensão da continuidade histórica da pátria, a compreensão dos problemas e das necessidades, da missão e dos ideais da nação, e bem assim dos perigos que a acompanhem, cerquem ou ameacem, um ensino capaz, além disto, de criar, no espírito das gerações novas, a consciência da responsabilidade diante dos valores maiores da pátria, a sua independência, a sua ordem, o seu destino (Brasil, 1942a).

Essa série se manifesta em outros diversos momentos, fazendo referência a uma "base de patriotismo", às atividades que deverão transcorrer "em termos de elevada dignidade e fervor patriótico" e à formação de uma “consciência patriótica”. Também se afirma que é relevante "desenvolver nos alunos uma justa compreensão da vida e da pátria", uma “consciência da significação histórica da pátria”, “da responsabilidade diante dos valores maiores da pátria”. E sobre o currículo do ensino secundário, afirma-se que dele “deveriam provir as individualidades responsáveis e dirigentes, as individualidades esclarecidas de sua missão social e patriótica, e capazes de cumpri-la”. Essas sequências funcionam como indícios de que a Reforma materializava um discurso que interpelava os indivíduos como patriotas dentro de um projeto mais amplo de cunho nacionalista.

Esse programa político justificava o objetivo de expansão do ensino secundário. A proposta de estendê-lo vem a tona em outro dos pontos da Exposição de Motivos que tratam da sua reorganização: a Divisão em dois ciclos. No documento se afirma que

a reforma conserva a divisão do ensino secundário em dois ciclos, dando, porém, uma configuração diferente a essa estrutura. O primeiro ciclo compreenderá um só curso: o curso ginasial, de quatro anos. O segundo terá dois cursos paralelos, cada qual com a duração de três anos, sendo qualquer deles acessível aos candidatos que tenham concluído o curso ginasial ${ }^{143}$.

\footnotetext{
${ }^{143}$ Vale lembrar que a antiga estrutura, que tinha sido definida na Reforma Francisco Campos de 1931, também estava dividida em dois ciclos. O primeiro, fundamental, de cinco anos, era um curso comum a todos e conferia formação geral. O segundo, complementar, de dois anos, era preparatório para o curso superior (Dallabrida, 2009, p. 186). Também é relevante lembrar que a estrutura dada pela Reforma Capanema permaneceu até início da década de 1970, quando foi criado o primeiro grau, a partir da fusão do curso primário com o ciclo ginasial, e o segundo grau, formado pelo ciclo colegial (ibid.).
} 
No entanto, o mais interessante dessa mudança na estrutura é compreender a sua finalidade. Limitar o curso ginasial a quatro anos traria algumas vantagens. Por um lado, "a de tornar a educação secundária, na primeira fase, ao alcance de um número maior de brasileiros” (Brasil, 1942a). Mais um gesto na direção de democratizar, propondo uma educação geral que pudesse chegar a mais pessoas. Por outro lado

a possibilidade de uma conveniente articulação do primeiro ciclo do ensino secundário com o segundo ciclo de todos os ramos especiais do ensino de segundo grau, isto é, com o ensino técnico industrial, agrícola, comercial e administrativo e com o ensino normal, servindo de base a essas categorias de ensinos, o que ocorrerá para maior utilização e democratização do ensino secundário, que assim não terá, como finalidade preparatória, apenas conduzir ao ensino superior (ibid.).

Havia uma preocupação com o mundo do trabalho e, desse modo, a articulação do primeiro ciclo aconteceria com "todos os ramos especiais do ensino de segundo grau”, ligados às práticas sociais (“ensino técnico-industrial, agrícola, comercial e administrativo e com o ensino normal”) e, novamente, se faz menção a um ensino que não se reduziria a uma finalidade preparatória para a fase superior, mas que nas diferentes articulações com o segundo ciclo de todos os ramos especiais buscava "uma maior utilização e democratização do ensino secundário”.

Outro ponto relevante de destacar é o que diz respeito a $O$ ensino das línguas vivas estrangeiras. Nele afirma-se que

O ensino secundário das nações cultas dá em regra a cada aluno o conhecimento de uma ou duas línguas vivas estrangeiras. Esse número é elevado a três pelos países cuja língua nacional não constitui um instrumento de grandes recursos culturais.

A reforma adotou esta última solução. Claro está que o francês e o inglês não poderiam deixar de ser conservados no número das línguas vivas estrangeiras do nosso ensino secundário, dada a importância desses dois idiomas na cultura universal e pelos vínculos de toda sorte que a eles nos prendem.

A reforma introduz o espanhol no grupo das línguas vivas estrangeiras de nossos estudos secundários (ibid.).

Nesse recorte, se faz presente uma formulação que introduz o espanhol como terceira língua dentro da tríade de línguas estrangeiras que aí se apresenta como regra geral. De acordo com ela, assume-se a posição de que o Brasil pertenceria ao segundo grupo de países, formando parte daqueles “cuja língua nacional não constitui um instrumento de grandes recursos culturais” (ibid.) e, por tal motivo, elevando a três o número de línguas estrangeiras ensinadas que, em caso das “nações cultas”, seriam duas. O espanhol é introduzido no grupo das línguas vivas estrangeiras, somando-se ao histórico ensino de 
francês e inglês ${ }^{144}$, línguas que, segundo o documento, “claro está”, "não poderiam deixar de ser conservad[as] (...) dada a importância desses dois idiomas na cultura universal e pelos vínculos de toda sorte que a eles nos prendem”. Não só interessa ressaltar a ordem em que são apresentadas as línguas (“francês e inglês”), mas o sintagma que introduz a formulação: “claro está”, apresentando sua presença como efeito de um pré-construído.

Em oposição ao modo como se dá continuidade ao ensino do francês e do inglês, a inclusão do espanhol vai sendo construída no discurso, expondo-se no documento os motivos que justificam a inclusão dessa terceira língua, em uma sequência que numeramos para a análise e que nos leva a ampliar as interpretações levantadas até agora sobre as mudanças ocorridas no quadro de línguas obrigatórias e a considerar outros aspectos

(i) Além de ser uma língua de antiga e vigorosa cultura e de grande riqueza bibliográfica para todas as modalidades de estudos modernos, (ii) é o espanhol a língua nacional do maior número dos países americanos. (iii) Adotá-lo no nosso ensino secundário, estudá-lo, não pela rama e autodidáticamente, mas de modo metódico e seguro, (iv) é um passo a mais que damos para a nossa maior e mais íntima vinculação espiritual com as nações irmãs do continente.

Analisando a primeira parte do recorte (i), Vieira (2012, p. 41) observa que o espanhol se vinculava a sentidos de uma língua de cultura notável e de acesso a uma riqueza de produção bibliográfica e isso, acrescentamos, parece se apresentar para o sujeito desse discurso também como uma evidência, um aspecto regularizado na memória (“além de ser...”). A autora também ressalta o enunciado (ii) em que se afirma que o espanhol é “a língua nacional do maior número dos países americanos”, observando que não se faz referência à Espanha ${ }^{145}$. Essa consideração parece bastante significativa e parece assinalar as preocupações do Estado com os países da região e com a importância política outorgada ao estudo de espanhol. Em relação com o ponto (ii), estudar a língua seria (iv) “um passo a mais” que o governo daria, nessa espécie de gradativa somatória para uma “maior e mais íntima vinculação espiritual com as nações irmãs do continente”. Materializa-se no discurso uma preocupação de aproximação do Brasil com os países hispano-americanos e isso daria à questão da língua e de seu aprendizado um lugar de maior relevância.

\footnotetext{
${ }^{144}$ Leffa (1999) afirma que muitos alunos terminavam o ensino médio lendo os autores na língua original. Para o estudioso, visto de uma perspectiva histórica, as décadas de 40 e 50, sob a Reforma Capanema, formam os anos dourados das línguas estrangeiras no Brasil.

145 Para Vieira (2012), esse apagamento poderia ser um gesto que materializaria o posicionamento do governo Vargas que buscava evitar relações com os países europeus vinculados a regimes nazifascistas, como era o caso da Espanha.
} 
Se na Exposição de Motivos se projeta essa aproximação ("vinculação espiritual”) com os países da região, relacionada também, nesse caso, com o aprendizado da língua, outros indícios reafirmam esses anseios.

Um deles refere-se à firma de tratados comerciais com países da América Latina, indicando esse movimento de aproximação com os países da região levado adiante durante o governo Vargas. Em um estudo histórico sobre as relações internacionais da América Latina, Cervo observa que na primeira metade da década de 1930, entre 1932 e 1936

Inúmeros tratados de comércio foram firmados entre países da América Latina com o intuito de abrir mercados aos países vizinhos, em oportuna política de contrapeso ao fechamento econômico observado no mundo em conseqüência da crise do capitalismo (2001, p. 66).

O autor também menciona o tratado firmado com a Argentina em 1941, na visita realizada por Oswaldo Aranha (Ministro das Relações Exteriores) a Buenos Aires em novembro desse ano. Assim, destaca (ibid., p. 76) que nessa visita "os dois grandes do Atlântico sul também firmaram um tratado de comércio cujo espírito era o de induzir uma união aduaneira aberta à adesão dos vizinhos”146. Segundo o estudioso, Aranha combinava o estímulo ao pan-americanismo (“a solidariedade com os países latinos”"147 [ibid. p. 77]) por um lado, com o americanismo ("a fiel e estreita relação com os Estados Unidos”). Porém, ainda segundo Cervo, demonstrando sua autonomia na política exterior, “o governo brasileiro soube com arte política separar suas relações especiais com os Estados Unidos da determinação desse país de castigar a Argentina pela sua neutralidade” na segunda guerra mundial (ibid. p. 66), estendendo-lhe a mão em nome da solidariedade latina (ibid. p. 50 e 77) ${ }^{148}$. Além dos sentidos expressos na Exposição de Motivos, as relações econômicas e comerciais também propiciavam a aproximação entre os países do continente.

\footnotetext{
${ }^{146}$ O Tratado sobre Livre Comércio Progressivo tinha o propósito de estabelecer um regime de livre intercâmbio comercial que pudesse chegar a uma união aduaneira com os países limítrofes (Rapoport, 1998). ${ }^{147}$ No primeiro capítulo da tese trouxemos o modo como Arnoux e Del Valle (2015) compreendem as diferenças entre "panamericanismo" e "latinoamericanismo", estabelecendo para o primeiro sentidos diferentes aos manifestados aqui por Cervo. Aqui reproduzimos as palavras do estudioso das relações internacionais do Brasil, mas vale salientar que nos inscrevemos na compreensão que Arnoux e Del Valle fazem ao respeito dos conceitos.

${ }^{148}$ Sobre esse assunto, ver também Cervo e Rapoport (1998). Em janeiro de 1942, na Conferência Panamericana reunida no Rio de Janeiro, os Estados Unidos buscaram obter que os países latino-americanos rompessem suas relações com as potências do Eixo. A Argentina e o Chile mantiveram uma posição neutral criando enfrentamento e tensão nas relações com os Estados Unidos (Rapoport, Madrid, 1998).
} 
Nesse mesmo sentido, identificamos três $\operatorname{cartas}^{149}$ que reafirmam a preocupação do governo para se aproximar aos países da região e que têm Gustavo Capanema - o autor da Exposição de Motivos - ora como destinatário, ora como autor do intercâmbio epistolar. Na primeira delas, endereçada a ele por Gilberto Freire, de Recife em 21 de agosto de 1941, o sociólogo pernambucano faz menção a uma conversa que teria colocado a amizade com Capanema "em uma nova fase" e na qual o ministro teria mencionado seu interesse pelos estudos de Freire sobre as condições intelectuais nos países americanos “para uma melhor articulação da nossa cultura com a deles”. Para contribuir com o plano de Capanema, Freire se propõe a desempenhar a missão de “observador cultural”, tanto das condições daquele momento, como das que seriam necessárias para uma aproximação intelectual com esses países, "no sentido de intercâmbio universitário, em particular, e científico, literário e artístico, em geral”. E para isso, Freire propõe uma viagem de seis meses, começando pela Argentina, Uruguai e Paraguai para terminar nos Estados Unidos ${ }^{150}$. O sociólogo acrescenta que poderia fazer um trabalho de certo interesse dentro do plano de Capanema, o qual qualifica como sendo de "inteligente interamericanismo cultural" e define como bem diverso do que teria existido até esse momento. Freire solicita a Capanema a possibilidade de resolver a concretização da viagem junto ao presidente Vargas.

Na segunda carta, escrita dois meses depois (28.10.1941), Capanema se dirige ao presidente Vargas, explicando a proposta e as despesas que a missão de Freire envolveria

\begin{abstract}
Sr. Presidente:
Apresento a V. Excia um plano de início de um cuidadoso trabalho de sondagem do ambiente cultural das nações hispanoamericanas, para verificação do que é possível fazer no sentido de uma maior, mais segura e mais continua penetração da cultura brasileira ${ }^{151}$.

A cultura brasileira é quase inteiramente desconhecida dessas nações. Vencer essa distância, não só em proveito de um maior entrelaçamento espiritual na América, senão também para que se alargue o prestígio do esforço intelectual de nosso país, é tarefa que se impõe aos homens do governo brasileiro (...).
\end{abstract}

\footnotetext{
${ }^{149}$ As cartas fazem parte de uma longa série apresentada no Apêndice do livro Tempos de Capanema, de Schwartzman, Bomeny e Costa (1984).

${ }^{150}$ Na mesma carta, Freire comenta com Capanema que a missão de observador cultural que estava sugerindo teria também o interesse de lhe servir de "viagem de núpcias", "daí a urgência”, "a grande urgência”, afirma o escritor pernambucano (ibid.). A viagem aconteceu e foi, assim, viagem de trabalho e de núpcias. Em Viagem como vocação, no capítulo dedicado a Gilberto Freyre e suas miradas sobre a América hispânica, Peixoto (2015, p. 116) também observa que "a viagem de núpcias ao sul do continente americano é também viagem de trabalho". Uma viagem que coincidiu com a publicação espanhola de Casa-grande \& Senzala e na qual foram realizadas diversas palestras e conferências nos países visitados cujo tema era América Latina (ibid.).

${ }^{151} \mathrm{O}$ fragmento em itálico parece antecipar as palavras que pouco tempo depois Capanema escreveria na Exposição de Motivos: "nossa maior e mais íntima vinculação espiritual com as nações irmãs do continente”.
} 
O trabalho, a ser realizado pelo escritor Gilberto Freire, deverá iniciar-se pelos países em que a tarefa parece mais fácil: Argentina, Uruguai, Paraguai e Bolívia. (apud Schwartzman, Bomeny e Costa, p. 316-317).

Nas duas cartas, a aproximação com os países americanos se projeta de forma nítida e, nessa última, claramente vinculada à intenção de que a cultura brasileira - "quase inteiramente desconhecida dessas nações” - “penetrasse” de forma continua. Essa série de aspectos nos permite alargar o contexto da incorporação da língua ao currículo.

Uma terceira carta, escrita por Freire em 31 de janeiro de 1942 desde o “profundo e misterioso” Paraguai, tal como ele mesmo registra já na missão pelos países vizinhos, também traz pistas interessantes. Freire afirma a importância da viagem com Capanema e observa o desejo dos paraguaios de um maior contato com a cultura brasileira:

Do que estou certo é de que esta viagem de estudo não será inútil para o Brasil. Aqui tenho encontrado da parte dos paraguaios a maior simpatia e vivo desejo de maior contato com a cultura brasileira. Seria ótimo que a Academia Brasileira de Letras, por exemplo, que não é nenhuma pobretona, estabelecesse aqui uma cadeira de estudos brasileiros que poderia se especializar no estudo de coisas de interesse comum sobre nossas origens ameríndias (ibid., p. 321 e 322).

E ainda retomando conversas anteriores com o Ministro, volta a mencionar velhos projetos e ideias:

A propósito: como supunha e como lhe disse, este ponto pode ser bastante natural, nada forçada, de maior aproximação cultural dos povos da América espanhola conosco. Já tenho falado do nosso congresso, para o ano, de estudos ameríndios e encontrado entusiasmo pela idéia. Nós somos, dos grandes povos da América do Sul, e, ao lado do México, o menos europeu e, essencialmente, o menos colonial na sua cultura e por conseguinte, em posição de ser o pioneiro de uma nova cultura americana, na qual se valorizem, em vez de se subestimarem, os elementos não-europeus (ibid.).

Freire falava da possibilidade de o Brasil ser "pioneiro de uma nova cultura americana”, assumindo uma posição de avançada, quase de liderança ${ }^{152}$.

E comenta, ainda, uma ideia “esplêndida” de Capanema sobre as origens ameríndias dos povos da América e sobre a projeção de Vargas como líder

A idéia do monumento ao índio - uma de suas esplêndidas idéias - será recebida com entusiasmo em toda a Indo-América, que também começa a sentir - e com razão - que o nosso Vargas é um dos seus leaders (ibid.).

Nos recortes acima, apresentamos diversos aspectos em que a aproximação com os países da região aparece anunciada de forma clara em diferentes materiais: na

\footnotetext{
152 Parecem ressoar aqui as palavras de Oliveira Lima apresentadas no capítulo 1 sobre as aspirações do Brasil de dividir a hegemonia hemisférica com os Estados Unidos, assumindo assim "essa liderança” e esse desejo de "uma maior e mais continua penetração cultural brasileira", como afirma Capanema na carta enviada a Vargas.
} 
Exposição de Motivos, em tratados comerciais e nas cartas. A soma dessas amostras dá sustento à possibilidade de trazer outra interpretação com relação à exclusão do alemão da grade de disciplinas obrigatórias e à inclusão do espanhol. Até aqui os argumentos de diversos pesquisadores (Rodrigues, 2012; Vieira, 2012) defendiam a ideia de que a exclusão do alemão do currículo de disciplinas obrigatórias (e a inclusão do espanhol no seu lugar) estaria relacionada à posição tomada pelo Brasil na guerra, alinhando-se aos aliados (Estados Unidos, Grão Bretanha, Francia e Rússia) em oposição aos países do eixo (Itália, Alemanha, Japão). As análises apresentadas nos permitem formular outros motivos possíveis para as mudanças ocorridas, levantando a hipótese que mais do que a guerra teria sido essa política de aproximação com os países da região a que teria marcado os movimentos acontecidos no currículo com relação às línguas estrangeiras.

Se as cartas fazem referência explícita a uma aproximação e a um desejo de maior conhecimento sobre os países da “América espanhola”, a Exposição de Motivos traz mais uma pista na direção da nossa hipótese. No próprio documento se faz referência ao alemão (e ao italiano), dando força a nossa interpretação que propõe somar sentidos ao que até agora tinha sido lido apenas como uma exclusão/inclusão de línguas (de alemão e de espanhol respectivamente) por causa da guerra. No documento se afirma que

\footnotetext{
É preciso não esquecer o valor cultural e a importância bibliográfica de outras línguas modernas, notadamente o alemão e o italiano.

Na impraticabilidade de ensiná-las nos limites de tempo e de capacidade pedagógica da escola secundária, será medida sem dúvida útil e de possível adoção introduzir o seu estudo, pelo menos em caráter facultativo, nos estabelecimentos de ensino superior, ao lado dos estudos científicos e técnicos para os quais elas constituem elemento auxiliar de primeira necessidade (Brasil, 1942a).
}

A despeito da proibição do ensino de alemão e de italiano (como línguas de imigração) nas comunidades do Sul do Brasil, no recorte fica clara a proposta para que essas duas línguas pudessem ser ofertadas de forma facultativa no ensino superior, ao lado dos estudos científicos e técnicos, devido ao valor cultural e à importância bibliográfica. O gesto de relacionar o ensino de alemão e italiano aos estudos científicos e técnicos nos leva a pensar que o aspecto humanístico do ensino ficaria vinculado mais estreitamente às outras línguas. E, se por um lado, nas diretrizes ministeriais não se faz nenhuma referência aos motivos que levaram a excluir o alemão do quadro de línguas obrigatórias, há um reforço da importância dessa língua na formação, por ser um “elemento auxiliar de primeira necessidade”. A série de fragmentos apresentada nos 
leva a pensar que, ao que parece, havia questões políticas de diversas ordens que implicavam uma mudança no quadro das relações entre as línguas e o espanhol passava a ter uma posição de maior destaque nesse espaço de enunciação (Guimarães, 2002). Em definitivo, aquela “maior e mais íntima vinculação espiritual com as nações irmãs do continente”, parecia não ser possível sem um estudo da língua, estudo esse que se antecipava como devendo ser mais aprofundado.

Retomamos, assim, a análise do recorte da Exposição de Motivos, no qual numeramos (i, ii, iii, iv) as justificativas da inclusão da língua espanhola no currículo, para abordar especialmente o item iii:

Adotá-lo [o espanhol] no nosso ensino secundário, estudá-lo, não pela rama e autodidáticamente, mas de modo metódico e seguro.

Sobre esse aspecto, Vieira (2012) chama a atenção para a proposta de estudar a língua "não pela rama e autodidáticamente”, ou seja, para não estudá-la sem aprofundamento e de maneira superficial, com a espontaneidade e informalidade de um autodidata, mas, “de modo metódico e seguro". Em contraposição a um estudo autodidata, os adjetivos "metódico e seguro” parecem remeter à escola, o âmbito onde poderia ser feito um estudo formal.

Ampliando a interpretação, interessa-nos assinalar que essa sequência do documento parece retomar sentidos que Nascentes formulara na Introdução da Gramática de espanhol escrita em 1920, na qual se referia à grande vantagem de ter um conhecimento "não perfunctório" (não superficial) da língua ${ }^{153}$. Assim como para o autor da Gramática de 1920, para quem o lugar de estudar uma língua estrangeira de modo não superficial era a escola, o documento que expõe os motivos para levar adiante a Reforma Capanema também parecia reconhecer que a escola era o lugar para que a língua espanhola fosse estudada "não pela rama”, nem "autodidáticamente”, "mas de modo metódico e seguro”.

Nas passagens presentes na Gramática de 1920 (“não perfunctório”) e na Exposição de Motivos de 1942 (“não pela rama nem autodidáticamente”) é significativo observar o paralelismo das negações e expandir a reflexão a partir delas. Segundo Indursky (2013), a negação é um dos processos de internalização de enunciados oriundos de outros discursos e seu estudo possibilita evidenciar o caráter heterogêneo

\footnotetext{
${ }^{153}$ Retomando as palavras do autor já apresentadas ao abordarmos a Gramática no capítulo 1: “Estando o Brasil cercado de países onde se fala o espanhol e com os quais se acha em relações constantes, de ordem política, comercial, etc. é de grande vantagem o conhecimento não perfunctório daquella língua, assim como o da língua portuguesa o é para os naturais de outros países da América do Sul” (Nascentes, 1934, p. 3).
} 
do discurso. Se por um lado, as marcas da negação são explícitas: não, nem; o discurso do outro é implícito: "não pode ser dito pelo[s] sujeito[s]" desses discursos - tal como nos permite afirmar Indursky (ibid. p. 266). A própria autora ressalta que para identificar esse discurso que não está explicitado, é preciso transformar metodologicamente a negação em afirmação (ibid., p. 277), só assim, observa, o outro discurso pode ser tangenciado. Realizando essa operação, podemos pensar que ter um conhecimento superficial da língua e estudá-la de forma autodidata (discursos do sentido comum, apresentando-se como óbvios e sabidos no funcionamento da memória) seriam duas operações suficientes para certo domínio da língua, sentidos que os discursos de 1920 e de 1942 parecem querer interromper, negando-os. Vale aqui pensar que excetuando os cinco anos em que o espanhol esteve presente na grade do Colégio Pedro II (de 1920 a 1925), o estudo provavelmente era de forma autodidata.

Além disso, a partir das argumentações presentes na Introdução da Gramática (1920) e na Exposição de Motivos (1942), podemos inferir que nessas décadas o Mercado ainda não tinha desenvolvido uma indústria de ensino privado em torno às línguas estrangeiras para disputar com a escola o seu ensino. O lugar de estudar línguas estrangeiras de forma aprofundada, metódica, segura e plurilíngue era a escola. O desenvolvimento dessa indústria paralela que vai disputar com a escola do Estado o ensino de espanhol vai acontecer com força a partir de 1990 (Sokolowicz, 2014), mudando o paradigma da primeira metade do século XX e tentando negar a escola como espaço prioritário para a formação linguística dos estudantes.

Na Exposição de Motivos observavam-se também aspectos metodológicos (em uma formulação na qual ecoam ideias dos educadores escolanovistas), propondo certas mudanças com relação à velha memorização de regras, teorias e denominações, e projetando a inter-relação marcada pela cooperação no trabalho, a necessidade “de discutir e verificar”, “de ver e fazer”. Propunha-se, nesse sentido, uma mudança na atitude do professor:

No ensino científico, mais do que em qualquer outro, falhará sempre irremediávelmente o processo do erudito monologar docente, a atitude do professor que realiza uma experiência diante dos alunos inexpertos como se estivesse fazendo uma representação, o método de inscrever na memória a ciência dos livros. Nas aulas das disciplinas científicas, os alunos terão que discutir e verificar, terão que ver e fazer. Entre eles e o professor é necessário estabelecer um regime de cooperação no trabalho, trabalho que deverá estar cheio de vida e que seja sempre, segundo o preceito deweyano, uma "reconstrução da experiência” (Brasil, 1942a). 
De fato, a relação professor-aluno puxava o carro do ensino científico projetando um novo paradigma. Isso, transposto às humanidades e ao ensino das línguas, também implicava em outros métodos e na incorporação da dimensão oral da língua no processo de ensino-aprendizado, até então desconsiderada, como veremos no próximo item.

O Ministério da Educação contava com intelectuais de diversas filiações ideológicas (Napolitano, 2017). Nesse contexto, administrar os confrontos e debates (especialmente entre a corrente católica e a da Escola Nova) e abrigar as diversas posições foi uma característica do governo. Já concluindo a Exposição de Motivos, o Ministro esclarece que "foi ouvida a opinião de representantes de todas as correntes pedagógicas”, procurando “conciliar tendências opostas ou divergentes”. As pressões das diferentes correntes, buscando defender a presença de suas ideias na Reforma Educativa, deixaram marcas nos dois documentos ministeriais. Segundo Napolitano (2017), o resultado foi uma Reforma que procurou acomodar interesses e posições.

Na carta dirigida a Vargas, que acompanha a Exposição de Motivos, Capanema afirmava que se a Reforma merecesse aprovação, era de crer que o ensino secundário daria um passo a mais no sentido da renovação e da elevação. Em 9 de abril de 1942, uma semana após ter recebido a Exposição de Motivos, o Presidente da República decretou a Lei Orgânica do Ensino Secundário ${ }^{154}$. Do texto jurídico nos interessam alguns pontos que iluminam as posições que o Estado foi assumindo e são marcas das disputas de interesses, e outros, mais específicos, que reforçam certos aspectos já assinalados na Exposição de Motivos. Sobre os primeiros, parece importante chamar a atenção para a incorporação da educação física como prática educativa obrigatória até os vinte anos (capítulo IV, art. 19), uma imposição, segundo Napolitano (2017), das Forças Armadas. Também, a referência à educação militar que seria obrigatória para os alunos do sexo masculino dos estabelecimentos de ensino secundário (capítulo V, art. 20). Na Reforma também se afirma que o ensino da religião era parte integrante da educação dos adolescentes (capítulo VI, art. 21). Com relação a essa última e na disputa de interesses, Napolitano assinala que a Igreja - que não tinha simpatia pela expansão

\footnotetext{
${ }^{154}$ Vale lembrar aqui que ao longo do Estado Novo, o congresso se manteve fechado. Dessa forma, as decisões do governo não passavam nem pelas tensões, nem pelos obstáculos, nem por possíveis recusas nas Câmaras. Um aspecto significativo, quando se trata de compreender as diferenças com outros momentos históricos. Pensamos, especificamente, nas dificuldades enfrentadas pelo governo de Juscelino Kubitschek, no que foi, entendemos, o projeto mais ousado na historia do espanhol no Brasil e que propôs, em 1958, a equiparação do espanhol ao inglês e ao francês no sistema educativo, tanto em anos, quanto em número de horas destinadas ao ensino. A impossibilidade da aprovação esteve vinculada às disputas de forças que o funcionamento das câmaras impunha. Voltaremos a esse projeto nas Considerações finais da tese.
} 
de um ensino público e laico e que "comandava uma vasta rede escolar privada” (ibid. p. 147) - foi atendida na manutenção do ensino religioso na escola pública. É interessante observar que o Estado estabelecia a liberdade do ensino religioso (que era opcional), mas não era ele que iria regulá-lo: “Os programas de ensino de religião e o seu regime didático serão fixados pela autoridade eclesiástica” (Brasil, 1942b). Por último, cabe assinalar que o capítulo VII da Reforma demarcava todo o que dizia respeito à educação moral e cívica.

Ao longo da Reforma, especialmente nas Finalidades do Ensino Secundário, se reforçavam aspectos já formulados na Exposição de Motivos: a formação ampla, humanista e da personalidade integral dos adolescentes e a elevação da "consciência patriótica” que trouxe uma ênfase nos conteúdos nacionalistas. Também, o anúncio já feito com relação aos dois ciclos. O primeiro, o ginasial, de quatro anos e, o segundo, o curso clássico ou científico, com duração de três anos.

A menção à inclusão do espanhol aparecia no título "Da estrutura do ensino secundário”, especificamente na seção: “Dos cursos clássico e científico”. No artículo 14 e 15 enumeravam-se as disciplinas dos dois cursos, ficando da seguinte forma na grade curricular:

Art. 14. As disciplinas constitutivas do curso clássico terão a seguinte seriação: Primeira série: 1) Português. 2) Latim. 3) Grego. 4) Francês ou Inglês. 5) Espanhol. 6) Matemática. 7) História geral. 8) Geografia geral. Segunda série: 1) Português. 2) Latim. 3) Grego. 4) Francês ou Inglês. 5) Espanhol. 6) Matemática. 7) Física. 8) Química. 9) História geral. 10) Geografia geral. Terceira série: 1) Português. 2) Latim. 3) Grego. 4) Matemática. 5) Física. 6) Química. 7) Biologia. 8) História do Brasil. 9) Geografia do Brasil. 10) Filosofia (grifos nossos).

Art. 15. As disciplinas constitutivas do curso científico terão a seguinte seriação: Primeira série: 1) Português. 2) Francês. 3) Inglês. 4) Espanhol. 5) Matemática. 6) Física. 7) Química. 8) História geral. 9) Geografia geral. Segunda série: 1) Português. 2) Francês. 3) Inglês. 4) Matemática. 5) Física. 6) Química. 7) Biologia. 8) História geral. 9) Geografia geral. 10) Desenho. Terceira série: 1) Português. 2) Matemática. 3) Física. 4) Química. 5) Biologia. 6) História do Brasil. 7) Geografia do Brasil. 8) Filosofia. 9) Desenho (grifos nossos).

O espanhol era oferecido nas duas primeiras séries do curso clássico e na primeira série do científico.

Sobre os programas das disciplinas, a Reforma ressaltava que deveriam ser “simples, claros e flexíveis” e indicar "o sumário da matéria e das diretrizes essenciais”. Afirmava-se que os programas seriam sempre “organizados por uma comissão geral ou por comissões especiais, designadas pelo Ministro da Educação, que os expedirá”. 
Assim como a produção da Gramática escrita por Nascentes em 1920 teve que se ater ao Programa elaborado para a disciplina pela Congregação do Colégio Pedro II, os livros produzidos após a Reforma Capanema, que incluiu a língua espanhola na grade curricular, procuraram atender não só as demandas surgidas pela incorporação da língua, mas, especialmente, as diretrizes do Programa elaborado desde o Ministério. Programa e diretrizes que, como em décadas anteriores, também impactaram a elaboração dos instrumentos linguísticos, com um agregado no grau de determinação: a partir de 1938, os livros deveriam passar pela aprovação da Comissão Nacional do Livro Didático ${ }^{155}$.

A política centralizadora do Estado Novo e a ambição de construir uma identidade nacional levaram o regime à criação da Comissão Nacional do Livro Didático, pelo Decreto lei $n^{\circ} 1.006$, de 30 de dezembro de 1938. Embora tenha sido a primeira Comissão de caráter nacional instituída pelo governo brasileiro para controle de conteúdos ideológicos e pedagógicos de toda a produção didática no país, a burocracia administrativa e conflitos de interesses políticos e econômicos teriam impedido a aplicação efetiva, no campo prático, desta medida (Ferreira, 2008). Essa observação poderia justificar a circulação de livros que atenderam de forma bastante díspar as demandas estabelecidas no Programa para o ensino da língua.

A Comissão teria a função de autorizar (ou não) a utilização dos livros escolares na rede educativa. Segundo Ferreira (2008), o Decreto estabelecia que a partir de $1^{\circ}$ de janeiro de 1940 as escolas pré-primárias, primárias, normais, profissionais e secundárias, não poderiam adotar nenhum livro didático sem a autorização prévia do Ministério de Educação e Saúde. A autora também registra que nas escolas préprimárias e primárias a escolha seria feita pelo diretor, já nas normais, profissionais e secundárias os professores seriam os encarregados de escolher as obras que deviam constar na relação oficial de uso autorizado pela Comissão. Em 1942 houve uma interrupção do trabalho da Comissão, produto da aplicação da Lei Orgânica de Ensino. Foi necessário realizar uma adaptação após as modificações sofridas por alguns programas após a reorganização do ensino. A Comissão foi reinstalada em março de 1944, sob uma nova configuração (Ferreira, 2008).

\footnotetext{
155 Essa é, claramente, uma constante quando se pensa na elaboração de instrumentos linguísticos. O Programa de Português de 1887 para os Exames preparatórios, também tivera impacto direto na elaboração de uma série de gramáticas de Português produzidas nesses anos. E no caso da língua espanhola, mais recentemente as diretrizes estabelecidas pelo Programa Nacional do Livro Didático (PNLD) também afetariam a produção dos livros para a escola pública, sendo 2011 o primeiro ano de circulação dos livros selecionados pelo Programa no ano anterior.
} 
Voltando aos programas de ensino elaborados pelo Ministério da Educação e Saúde é preciso lembrar que estabeleciam as diretrizes que seriam observadas pela Comissão. Pensando no Programa de espanhol, cabe perguntar: quais eram suas particularidades e que efeitos diversos produziram? Essas interrogações nos levam ao próximo item do capítulo.

\section{Programa de espanhol dos cursos clássico e científico: representações ampliadas}

Como já dito, o que constituía o caráter específico do ensino secundário era, não só a questão humanística, mas a função de formar nos adolescentes uma "sólida cultura geral”. Diante dessa afirmação caberia perguntar: como se materializa a consideração desse aspecto específico no âmbito da língua espanhola? Que mudanças ocorrem com relação ao Programa do Colégio Pedro II, de 1919? Quais são as marcas que permitem rastrear essas mudanças e a projeção de um ensino preocupado com uma sólida formação cultural dos adolescentes? Que efeitos esse Programa teve não só na produção de instrumentos linguísticos, mas também nas transformações da estrutura desses instrumentos, isto é, no surgimento no ensino da língua espanhola de um gênero discursivo que pudesse atender melhor as diretrizes propostas, ultrapassando o contorno da língua do qual, até esse momento, tinham dado conta as gramáticas?

Em 3 de fevereiro de 1943, na Portaria No 127, assinada por Gustavo Capanema no Rio de Janeiro se afirmava que: “O Ministro de Estado da Educação e Saúde, resolve expedir e determinar que se execute o programa de espanhol que se anexa à presente portaria, dos cursos clássico e científico do ensino secundário” (Brasil, 1943). Se a análise da Exposição de Motivos e da Reforma nos permitiu identificar a projeção de um programa político, de um projeto nacional de educação e a proposta de uma formação mais ampla dos adolescentes, a análise do Programa expedido pelo Estado e composto de quatro partes - 1. Leitura; 2. Gramática; 3. Noções de História Literária; 4. Outros exercícios -, possibilitará compreender aspectos projetados para essa disciplina específica. A primeira parte, “Leitura”, anunciava-se da seguinte forma:

far-se-á em trechos fáceis, em prosa e em verso, que tenham por assunto principal a paisagem e a vida na Espanha e nos países americanos de língua espanhola e, posteriormente, por já aspirar a constituir uma iniciação literária em excertos dos maiores escritores espanhóis e hispano-americanos (ibid.).

Percorrer nos textos (em prosa e em verso) a paisagem e a vida dos países hispano-americanos e da Espanha era o objetivo dessas leituras iniciais. Nelas, a língua 
ficava ao serviço do reconhecimento dessas vidas diversas. Essas intenções formuladas no Programa com relação às leituras já sinalizavam mudanças significativas e estavam presentes e destacadas explicitamente por Idel Becker no Prólogo do Compêndio de Literatura Espanhola e Hispano-Americana, obra lançada em 1943 que serviu de fonte para extrair as leituras que comporiam as diferentes versões do Manual. Diz o autor:

\begin{abstract}
Esta Antologia Espanhola - comentada em língua portuguesa - foi especialmente organizada para os alunos brasileiros dos cursos Clássico e Científico.

Seguiu-se a orientação geral do Programa de Espanhol, apresentando-se trechos cujo assunto principal é "a paisagem e a vida na Espanha e nos países americanos de língua espanhola". Foram acrescentados "excertos dos maiores escritores espanhóis e hispano-americanos”: seleções poéticas de essencial valor artístico ou bibliográfico, e fragmentos em prosa, quer notáveis pela forma ou pelo sentido, quer sugestivos pela projeção literária do autor, quer de especial interesse léxico ou temático para alunos brasileiros. Ao lado da prosa castiça, apuradamente clássica, incluíram-se alguns exemplos pitorescos de fala regional (Becker, 1943, p. 17, itálico nosso).
\end{abstract}

As diretrizes sobre as leituras aparecem explicitamente anunciadas como organizadoras do Compêndio de Literatura, escrito especialmente para alunos brasileiros. "Excertos dos maiores escritores espanhóis e hispano-americanos” e "trechos cujo assunto principal é a paisagem e a vida na Espanha e nos países americanos de língua espanhola” compõem e organizam a obra. Desse modo, explicitase a forma como a obra acompanha os pontos formulados no Programa, atendendo, assim, as diretrizes oficiais.

Voltando para o Programa, a segunda parte, “Gramática”, aproximava-se, de forma enxuta, ao Programa do Colégio Pedro II de 1919, focando tópicos que não apresentam especificidades para o ensino de espanhol e sim as características do ensino gramatical de qualquer língua, conforme as concepções da época. Com o apoio nas leituras propostas no item prévio, propunha-se a tratar os seguintes tópicos:

Unidade I:

1. Artigos, substantivos, adjetivos, pronomes e numerais

2. Flexões de número, gênero e grau.

Unidade II:

1. Verbos: pessoas, número, tempos e modos.

2. Vozes.

3. Verbos auxiliares haver e ser

4. Verbos regulares e irregulares.

Unidade III:

1. Formação das palavras. Composição e derivação. Prefixos e sufixos.

2. Principais regras de concordância

3. Regência.

4. Construção.

5. Arcaísmo e neologismos.

6. Barbarismos e solecismos.

7. Idiotismos. 
Essa segunda parte do Programa apresenta um recorte dos tópicos propostos em 1919, em que a gramática era a tônica e o único componente do programa. No capítulo 2 assinalamos que a incorporação dos "barbarismos e solecismos” na Gramática de Nascentes tinha respondido a uma decisão do autor - desenvolvida com base na Gramática da RAE de 1917 -, já que não estava presente no Programa da respectiva disciplina, publicado no Diário Oficial. Em 1943 esse tópico faz parte das diretrizes ministeriais (no ponto 6 da Unidade III), integrando o programa oficial da disciplina.

Desse modo, vemos que nos anos centrais do século XX, continuam presentes os “arcaísmos e neologismos", os "barbarismos e solecismos" e os "idiotismos”, num livro destinado ao ensino do espanhol nas escolas secundárias do Brasil. Tópicos todos que mais do que apresentar uma descrição linguística abordam a prescrição a partir de um centro e de uma norma purista.

A terceira parte do Programa de 1943, "Noções de história literária”, propunha abordar na Unidade IV: "Períodos em que se divide a história da literatura espanhola, com indicação dos principais escritores e de suas principais obras” e, na Unidade V: “Os principais escritores, e suas principais obras, dos países americanos de língua espanhola”. Os conteúdos formulados nessas duas unidades, em certa medida, impulsionaram nesses anos a produção específica de alguns compêndios de literatura, ausentes em décadas anteriores, dentre eles o do próprio Idel Becker ${ }^{156}$.

Nesse sentido, cabe observar que o já referido Compêndio de Literatura de Becker foi produzido dois anos antes que o Manual e serviu de base para toda a seleção literária do livro de 1945. As duas obras apresentam marcas da influência pedagógica e literária rioplatense, especialmente a que exerceu Roberto Giusti nos anos de formação de Becker na Argentina, como veremos na quarta seção do capítulo. Fazemos essa afirmação, por um lado, pela seleção que compõe no Compêndio a parte da Antologia dedicada à literatura Hispano-americana, em que a Argentina está presente com dezoito autores; México, Peru, Colômbia, Uruguai e Cuba com três; Equador e Venezuela com dois e Nicarágua com um. E especialmente, pelas continuas citações que, principalmente no Manual, Becker faz de seu professor argentino.

\footnotetext{
${ }^{156}$ Como exemplos desses compêndios, podemos mencionar a Antologia espanhola e hispano-americana, de Antenor Nascentes (1943); o Compêndio de literatura espanhola e Hispano-americana, de Idel Becker (1943); a Antología española, de Leônidas Sobrino Porto (1944); e uma Literatura hispano-americana, de Manuel Bandeira (1949). Obras cuja comparação será interessante tratar em trabalhos futuros.
} 
Na quarta parte do Programa, “Outros exercícios”, eram feitas diferentes propostas: “1. Exposições orais, reprodução livre dos trechos lidos na aula. 2. Exercícios para ampliação de vocabulário. 3. Exercícios de redação e de composição. 4. Exercício de ortofonia e de ortografia. 5. Exercícios de tradução e de versão”. Se por um lado esses exercícios apontavam ao desenvolvimento da escrita e da tradução, uma tradição bastante presente no ensino de línguas estrangeiras da época, também estava presente a proposta de abordar a dimensão oral da língua por meio de exposições e da expressão oral (livre) sobre trechos lidos durante as aulas.

A produção dos instrumentos linguísticos deveria se submeter a esse programa curricular estabelecido pelo Estado que fixava habilidades e saberes considerados importantes de serem desenvolvidos na escola e cuja materialização nos livros seria avaliada pela Comissão Nacional do Livro Didático. O Programa propunha abordar “a paisagem e a vida na Espanha e nos países americanos de língua espanhola” e as diversas literaturas integradas, por um lado, aos tópicos gramaticais, e por outro, a exercícios dirigidos a práticas da dimensão oral e escrita da língua. Vê-se, assim, que as diretrizes do programa proposto em 1943 expandiam as representações sobre a língua que deveria ser estudada. Poderia uma gramática atender essas novas representações projetadas para o espanhol na escola? Que mudanças exigiram essas diretrizes e que indícios dessas novas demandas podem ser encontrados no campo da gramatização da língua, isto é, na amplia produção de instrumentos linguísticos ocorrida depois da incorporação do espanhol no currículo do ensino secundário?

À Gramática de Nascentes produzida em 1920, soma-se outra série de gramáticas. E a essas obras somam-se outros instrumentos linguísticos que trazem a estrutura de outro gênero: o manual, que tentaria dar conta, justamente, dessa ampliação. Como diria Bakhtin (1997, p. 279), muda a construção composicional. No surgimento do novo gênero ${ }^{157}$ parece bem produtiva a afirmação do pensador russo: “cada esfera da atividade humana comporta um repertório de gêneros do discurso que vai diferenciando-se e ampliando-se à medida que a própria esfera se desenvolve e fica

\footnotetext{
${ }^{157}$ Evidentemente poderíamos pensar as gramáticas e os manuais de forma ampla, como obras de caráter pedagógico - e com uma estrutura seqüencial de apresentação dos saberes - destinadas ao ensino da língua na escola ou em outros âmbitos. No entanto, como afirma Bakhtin, pensamos nas especificidades da construção composicional, fato que nos leva a falar em gêneros diferentes, que, fundamentalmente, respondem a exigências sociais, pedagógicas e educativas também diferentes. São gêneros que demandam outro tipo de trabalho do professor: as gramáticas demandavam um maior trabalho na organização e preparação de exercícios ou práticas, uma organização que o manual resolve de modo específico na sua própria estruturação.
} 
mais complexa”. O processo de gramatização do espanhol respondia, assim, à própria ampliação e complexificação dessa prática dentro do aparato escolar.

Nesse contexto, vemos surgir ao longo da década de 1940 (especialmente na primeira metade) uma ampla produção de instrumentos linguísticos, elaborados por diferentes autores, produzidos por editoras diversas dentro do território nacional, o que implica circulações mais ou menos restritas nesse âmbito. Nesse contexto de expressiva produção, cabe perguntar: que livros integraram essa aceleração? E dentro desse conjunto, que elementos dão destaque ao Manual de Idel Becker, escolhido por nós para uma análise mais aprofundada? Ao final, por que esse Manual? Quais os aspectos que, entendemos, o colocam como obra paradigmática de uma época? As análises desenvolvidas no próximo item e aprofundadas no próximo capítulo tentam responder essas perguntas.

\section{Um mercado editorial em expansão: a produção acelerada de livros de espanhol}

A incorporação do espanhol no currículo da escola secundária provocou o rápido surgimento de uma produção significativa de livros destinados a esse destinatário específico. Antes de abordarmos essa questão central da seção, parece interessante uma passagem pelo período compreendido entre a saída da língua do Colégio Pedro II (1925) e sua entrada, durante o governo Vargas, no currículo da escola secundária (1942). Em que âmbitos, embora ainda bastante restritos, o espanhol esteve presente nesses dezessete anos que separam os dois acontecimentos? Guimarães (2018) mapeia em cada uma das décadas compreendidas entre 1919 e 1961 a legislação e os programas oficiais, os métodos prescritos e a produção de livros didáticos.

O trabalho do pesquisador (ibid., p. 80-83) segue um percurso cronológico e, a partir dele podemos sintetizar os vaivens do espanhol em diversos âmbitos educativos da seguinte forma: em 1926 existia o ensino optativo da língua no ensino comercial e na Escola do Estado Maior, no entanto, em 1931 o espanhol saiu do Ensino Superior Comercial; em 1929 tinha sido criada a disciplina Literatura, cujo programa contemplava o estudo das literaturas espanhola e hispano-americanas. Ainda segundo Guimarães (ibid.), em 1935 havia aulas à distância na radio Ipanema (quinze minutos às quintas-feiras) e em 1937, o Conselho Nacional de Educação estabeleceu o ensino da língua espanhola nas faculdades de ciências e letras, na seção de línguas neolatinas. 
Vê-se, assim, a presença da língua em diferentes âmbitos, fato que poderia justificar as edições subsequentes da Gramática de Nascentes ${ }^{158}$ - única produção brasileira em circulação até inicio dos anos 1940 -, mesmo após a língua ter sido retirada do currículo do Colégio Pedro II. Guimarães (2018) registra a aceleração produzida, afirmando que foram 22 obras de 19 autores $^{159}$.

Em uma pré-análise de parte dessa vasta produção, tentamos observar regularidades e diferenças e justificar a escolha do Manual de Idel Becker como obra significativa de uma época: foi a que teve mais edições e maior circulação ao longo da história do ensino de espanhol no Brasil, entre 1945 e $1996^{160}$. Isso nos leva a perguntar: quais foram as especificidades do Manual que fizeram dele uma das obras mais importantes e difundidas da segunda metade do século XX? Por que essa longa permanência?

A entrada do espanhol no currículo em 1942 precipitou a produção de instrumentos linguísticos. É em 1943 e 1944 que o maior número de livros é lançado ao mercado. A lista abaixo, extraída do trabalho de Guimarães (2018), quem mapeia toda a década de 1940, apresenta os livros produzidos nesses dois anos:

- Adolfo Pozo y Pozo: Florilegio castellano. Rio de Janeiro, São Paulo, Belo Horizonte: Livraria Francisco Alves.

- Adolfo Pozo y Pozo: Gramática española. Rio de Janeiro, São Paulo, Belo Horizonte: Livraria Francisco Alves.

- Alfredo Lamarque Madrigal: Lengua española: método gramatical y ejercicios adaptados al programa oficial para os cursos clásico y científico. Rio De Janeiro: A. Coelho Branco F .

- Antenor Nascentes: Antologia espanhola e hispanoamericana. Rio De Janeiro: Livraria Editora Zelio Valverde.

- Idel Becker: Compêndio de literatura espanhola e hispanoamericana. São Paulo, Rio de Janeiro, Recife, Porto Alegre: Companhia Editora Nacional.

- Idel Becker: Espanhol, pontos gramaticais e trechos para exercícios. São Paulo: Edições Elo.

${ }^{158}$ Em 1934 já estava pela 3a edição e em 1945 é editada a 6 $6^{\text {a }}$ edição.

$159 \mathrm{O}$ autor fez também um levantamento das editoras que participam dessa expansão editorial e das cidades onde foram publicadas as obras (Guimarães, 2018, p. 98 e 99)

${ }^{160}$ A edição mais recente do Manual que conseguimos rastrear foi de 1996. 
- Beatriz Magalhães de Chacel: El español del colegio: programa de la primera serie de los cursos clásico y científico. São Paulo, Rio de Janeiro, Recife, Bahia, Porto Alegre: Companhia Editora Nacional.

- Cândido Jucá (Filho): El castellano contemporáneo (gramática y texto): para uso de los colegios brasileños. Rio de Janeiro: Editora Panamerica.

- João de Souza Ferraz; Gastón Figueira: La lengua española: para o $2^{\circ}$ ciclo. São Carlos: Editora Didática Brasileira.

- Leônidas Sobrino Porto: Antología española. Rio de Janeiro: Companhia Editora Nacional.

- Raul Gil Lagomarsino: Gramática castellana - para uso nos cursos dos colégios brasileiros. Porto Alegre: A Nação.

- Sebastião Da Silva Neiva, Frei: Lectura castellana: trozos selectos, en prosa y verso, sacado de los mejores escritores españoles e hispanoamericanos. Petrópolis: Vozes.

- Vicente Solana; Bento Bueno de Morais: Gramática castellana. São Paulo: Edições e Publicações Brasil.

Deixando de lado as Antologias e os Compêndios - produzidos para dar conta das demandas pela inclusão do ensino das literaturas espanhola e hispano-americana -, uma leitura inicial dos títulos permite afirmar que o maior número de livros produzidos continuava respondendo ao gênero "gramática” - apesar das novas diretrizes ministeriais demandarem outros aspectos no trabalho com a língua.

Na lista acima, observamos que o gênero é marcado pelo próprio termo presente no título, como em: “Gramática española”, “Gramática castellana”, “El castellano contemporáneo (gramática y texto): para uso de los colegios brasileños” ou aparece deslocado numa especificação do subtítulo: “Lengua española: método gramatical y ejercicios adaptados”. Além disso, há uma diversidade no modo como esses instrumentos linguísticos designam o objeto de estudo: “El español del colégio (...)”, “Lengua española (...)”, “El castellano contemporáneo”, “Gramática castellana”. E, ainda, especificações que designam de modo também diverso o destinatário do âmbito escolar: "Lengua española: método gramatical y ejercicios adaptados al programa oficial para os cursos clásico y científico", "El español del colegio: programa de la primera serie de los cursos clásico y científico”, "La lengua española: para o $2^{\circ}$ ciclo". 
Buscando observar aspectos significativos, analisamos os paratextos de três gramáticas da lista acima: El castellano contemporáneo (Cândido Jucá filho, 1944), Gramática Castelhana (Vicente Solana e Bento Bueno de Morais, 1944), Gramática castellana. Para uso nos cursos dos colégios brasileiros (Raul G. Lagomarsino, 1944) ${ }^{161}$ e de uma quarta de 1948: Español - Gramática, Literatura y Antología, (Aristóteles de Paula Barros). Esses livros têm em comum o fato de terem sido produzidos por docentes e de anunciar-se (alguns deles) como respondendo ao Programa oficial da disciplina, embora nem sempre abordem o que as diretrizes propunham. Vejamos como isso aparece na obra de Solana e Bueno de Morais (1944, p. 4): “[Se buscó satisfacer] solamente las exigencias del programa oficial” e na apresentação que Luis Gonzaga e Jager fazem da obra de Lagomarsino (1944): “distinguem a presente obra ainda uma rigorosa obediência ao programa oficial, e uma admirável precisão nas definições e nítida clareza nas explicações”.

Também observamos, por um lado, a projeção de um aluno linguísticamente competente: "[o esboço gramatical] presume que o discente conheça regularmente a sua língua materna e salienta os pontos em que os dois idiomas se extremam” (Cândido Jucá, 1944, p. 5); por outro, a projeção de um aluno específico (o brasileiro) e a comparação com o português: “o esboço gramatical foi elaborado de comparação com o português, pois destina-se ao uso dos Brasileiros” (Cândido Jucá, 1944, p. 5), “como bem ensinar espanhol a alunos que falam o português?” (Lourenço Filho, ao apresentar a obra de Barros, 1948, p. 1). Duas dessas obras também fazem referência à proximidade/semelhanças das línguas: “Entre todos os idiomas “estrangeiros”, é o Espanhol - ou mais exatamente o CASTELHANO - o mais afim ao nosso” (Prefácio de Gonzaga-Jaeger, na obra de Lagomarsino, 1944), “dada a similaridade entre as duas línguas, em seu ensino, por essa mesma razão, ocorrem situações em que de forma pronunciada, manifesta-se a influência do que já se sabe sobre o que se pretende aprender” (apresentação de Lourenço Filho da obra de Barros, 1948). Por último, observamos a importância dada ao aprendizado da língua para um maior e melhor intercâmbio intelectual e social com os países da América Latina. Assim o manifestava Barros (1948, p. 3)

ao entregarmos aos nossos patrícios este despretensioso trabalho, o fazemos imbuídos do mais elevado espírito de cooperação, certos de que, assim procedendo, estaremos (...) ajudando, de acordo com as nossas humildes

${ }^{161}$ Outras duas obras não têm nenhum paratexto: Gramática española (Adolfo Pozo y Pozo, 1943) e El español del colegio, $1^{\circ}$ año de los Cursos Clásico y Científico (Beatriz Magalhães de Chacel, 1944). 
possibilidades, os grandes e salutares objetivos do nosso governo ao estabelecer, pelo ensino da língua espanhola, maior e mais fácil intercambio intelectual e social com os irmãos da América, a fim de fortalecer a cultura brasileira e, sobretudo, preservar, por esse meio, no presente e muito mais no futuro, a tão almejada paz entre os homens do Continente.

Lagomarsino também se manifestava nessa direção numa espécie de Prólogo intitulado Dedicatória e dirigido “À mocidade brasileira”

\begin{abstract}
Si o estudo de uma outra língua constitui novo elemento de cultura que permite ao homem satisfazer o desejo de saber dessedentando suas âncias nas próprias fontes originais, - o estudo do ESPANHOL se me afigura de valor maior como elemento básico e imprescindível para a integral realização de anseios que flutuam no ambiente (1944, p. 5, itálico nosso).

(...)

Homens de boa vontade procuram nas terras próximas falar vossa língua para melhor se entenderem convosco; fazei outro tanto; - e para que o Brasil mantenha sempre o lugar que lhe corresponde como vanguardeiro que é, material e espiritualmente, nas linhas de defesa do Continente da Paz aprendei a língua daqueles, para que, pelo entendimento mútuo, haja e seja uma radiosa realidade, o amor e a união fraternal que deve unir como irmãos todos os membros desta grande família das nações sul-americanas (ibid., itálico nosso).
\end{abstract}

As palavras do autor se referem, por um lado a "anseios que flutuam no ambiente" e, ampliando essa expressão, à necessidade de aprender a língua para que haja "o amor e a união fraternal" com os irmãos da "grande família das nações sul-americanas". Necessidades e anseios também expressados a partir do Estado. Essa necessidade, como em outros momentos do arquivo estudado, se antecipa vinculada a um movimento do próprio Brasil, significado como "vanguardista” no espaço continental.

Nesse sentido, outro aspecto interessante desse segundo recorte é a importância do aprendizado mútuo da língua: "Homens de boa vontade procuram nas terras próximas falar vossa língua para melhor se entenderem convosco; fazei outro tanto”. Algo que já em 1920 fora sinalizado por Nascentes na Introdução da Gramática.

Nesses recortes em que os autores se referem à importância do aprendizado da língua para levar adiante um melhor intercambio com os países da América Latina, vemos plasmadas certas vacilações políticas de época. A integração proposta pelo Estado e valorada pelos autores parece um denominador comum, no entanto, o modo como é interpretada essa aproximação apresenta algumas oscilações. Vejamos que no primeiro recorte (o de Barros) a fraternidade e a importância de aproximação visariam o desenvolvimento próprio (“os grandes e salutares objetivos do nosso governo ao estabelecer, pelo ensino da língua espanhola, maior e mais fácil intercambio intelectual e social com os irmãos da América, a fim de fortalecer a cultura brasileira (...)”). Por sua vez, como acabamos de assinalar, Lagomarsino destaca o lugar “vanguardeiro” do Brasil. 
A gramatização brasileira do espanhol tinha se iniciado em 1920 com a produção da Gramática de Nascentes, o discurso inaugural desse processo. No entanto, interessa observar que neste segundo gesto de inclusão do espanhol no currículo do ensino secundário, se ampliavam as geografias onde esse processo acontecia e se explicitavam algumas das suas dificuldades. Lagomarsino (1944), professor do Colégio Anchieta de Porto Alegre, em carta “Aos Srs Professores” presente na sua Gramática Castellana, assim se referia a esses dois aspectos:

Sendo esta obra a primeira do gênero editada no Estado, às dificuldades próprias de adatação da mesma às possibilidades intelectuais de determinada categoria de alunos, é preciso levar em conta as provenientes da composição tipográfica em língua estrangeira (...) (ibid. p. 6).

E completa, solicitando aos colegas indicarem os “defeitos, falhas ou excessos” e se desculpando por qualquer erro que possa ter escapado às revisões realizadas. O recorte também dá indícios da democratização do ensino (embora ainda em estado inicial) e da função do Estado na formação dos cidadãos que provinham, agora, de um espectro mais amplo da sociedade. As palavras referem-se "às dificuldades próprias de adaptação [da obra] às possibilidades intelectuais de determinada categoria de alunos”"

É em meio a essa expansão editorial que surgem em 1945 o livro de Idel Becker, já anunciado em seu título como manual (Manual de Espanhol), e o de Alvarez Calleja, Español Básico, de 1946 que, se não define o gênero no seu título, o faz na construção composicional assumida na sua elaboração, incorporando exercícios, leituras, e uma distribuição regular das lições. Embora sejam dois manuais dirigidos aos mesmos destinatários - os alunos dos cursos clássico e científico -, apresentam uma projeção diferente do aluno e do trabalho proposto com a língua. Seguindo a teorização de Bakhtin (1997, p. 284), para quem os gêneros do discurso constituem certo "tipo de enunciado relativamente estável do ponto de vista temático, composicional e estilístico”, podemos buscar compreender o "estilo individual” dessas realizações, nas quais, segundo o estudioso, “o autor da obra manifesta sua individualidade, sua visão de mundo” (ibid. p. 298) e é justamente esse cunho de individualidade, diz o autor, o aspecto que distingue uma obra das outras obras com as quais se relaciona. A partir da Análise do Discurso, podemos compreender esse "estilo individual” do qual fala Bakhtin como um trabalho de "autoria" - o modo como um individuo se coloca como sujeito da linguagem na origem do seu dizer, garantindo efeitos de coesão, coerência e unidade (Orlandi, 1996).

Assim, dada a contemporaneidade dessas duas produções, poderíamos nos perguntar: por que foi um desses manuais e não o outro, o que mais se projetou no 
tempo e o que teve mais reedições? Ao analisarmos o Manual de Espanhol no próximo capítulo, tentaremos confrontar, quando possível, alguns aspectos desses modos diferentes em que é projetada a língua, o ensino e o aluno a quem se destina. Embora não proponhamos uma comparação exaustiva - não é esse nosso objetivo -, nos aspectos confrontados apresentaremos - em notas - diferenças no modo como cada uma dessas obras responde às diretrizes do Programa formulado pelo Estado que implica, especialmente, em representações também diferentes.

\section{Idel Becker: aspectos biográficos e representações sobre a língua espanhola}

A diferença dos diversos artigos e trabalhos que nos permitiram expor no primeiro capítulo aspectos importantes da vida de Antenor Nascentes, um estudioso do português que participou ativamente dos debates sobre a língua e que esteve vinculado ao Estado brasileiro em diversos governos, existem poucas fontes e trabalhos que nos permitam ter uma compreensão mais aprofundada da vida de Idel Becker, o autor do Manual de Espanhol (1945). A maioria dessas informações pode ser encontrada em sites da internet e numa breve homenagem escrita por Saul Goldenberg, professor titular do departamento de cirurgia da Escola Paulista de Medicina ${ }^{162}$, logo após a morte do autor, em 1994. Sinteticamente, os aspectos que nos aproximam de sua biografia foram os seguintes: Idel Becker nasceu na localidade de Carlos Casares, Argentina, em 18 de dezembro de 1910, mas passou sua infância em Brasil, no Rio Grande do Sul, onde aprendeu a ler e escrever em três idiomas. Antes de seu nascimento, seus pais moravam numa colônia agrícola, perto de Erebango (RS) e como ali não havia recursos médicos atravessaram a fronteira por ocasião da aproximação do parto. Quinze dias depois do nascimento, a família mudou-se novamente para o Brasil. Com o tempo o filho naturalizou-se brasileiro e se graduou na Faculdade de Medicina da USP, atividade que exerceu entre 1940 e 1943. A partir dessa data optou por uma dedicação plena às letras. Foi professor de espanhol nos Colégios Rio Branco e Estadual Presidente Roosvelt e depois, na Faculdade de Ciências, Letras e Pedagogia da Universidade Mackenzie. Morreu em 1994.

162 Goldenberg era o Editor Científico responsável da Acta Cirúrgica Brasileira, onde saiu publicada no Vol. 9 (3) 1994, p. 107-108 a homenagem mencionada. 
Nenhuma das fontes consultadas, no entanto, apresenta indícios acerca de algo que parece fundamental na vida do autor e na produção das obras que escreveu sobre a língua espanhola e as literaturas hispânicas, algumas das quais serão utilizadas para o ensino de espanhol na escola secundária: a alternância da sua vida entre a Argentina e o Brasil, e uma formação escolar e universitária dividida entre esses dois países. Como mencionamos acima, nasceu na Argentina, foi criado na infância no Brasil, mas o interessante aqui é que voltou à Argentina "para cursar en ella los estudios secundarios”, como registra Roberto Giusti (1943, p. 13). Foram esses estudos, mencionados no Prefácio do Compêndio de Literatura Espanhola e Hispano-Americana (1943) ${ }^{163}$ e no Prólogo do Manual de Espanhol (1945), pelo próprio Giusti, um de seus professores no curso de Literatura no final do ensino médio ${ }^{164}$, os que colocaram Becker em contato com as literaturas hispânicas. Passadas algumas décadas, o autor sistematizaria essas experiências educativas na produção do Compêndio e do Manual. Após o ensino médio cursou a universidade de medicina em São Paulo, profissão que, como mencionamos, exerceu até 1943, época em que se debruça nas primeiras produções sobre a língua espanhola.

As idas e vindas de Becker entre a Argentina e o Brasil fez com que a sua vida se desenvolvesse no âmbito dessas duas culturas, como diz o próprio Giusti, quem afirma que "bien puede decirse que el portugués y el español son en el mismo grado sus lenguas maternas” (Giusti, 1943., p. 14). E foi o convívio com essas duas línguas o que ofereceu ao autor uma base importante na produção de uma trilogia: Compêndio de Literatura (1943), Dicionário espanhol-português e português-espanhol (1943) e Manual de Espanhol (1945), que analisada em seu conjunto, nos permitirá delinear algumas das concepções linguísticas aí presentes.

Embora o nosso foco seja o Manual, a análise dos paratextos dessa trilogia nos permitirá vislumbrar algumas das ideias do autor, ou mesmo de Giusti (quem fora seu professor e mentor intelectual), sobre a língua espanhola, sobre a compreensão que ele tinha da relação entre essa e o português e sobre os destinatários dos livros: o aluno brasileiro dos cursos clássico e científico e o professor da disciplina "língua espanhola” nesse âmbito de ensino. Assim, no próximo item analisaremos os paratextos da primeira

\footnotetext{
${ }^{163}$ Idel Becker, São Paulo - Rio de Janeiro - Recife - Porto Alegre: Companhia Editora Nacional, 1943. ${ }^{164}$ Giusti era membro da Academia Argentina de Letras e uma figura importante no campo literário da época, especialmente na produção de manuais que consagravam um cânone literário para o estudo das literaturas na escola secundária e gramáticas que propunham o estudo do idioma. Foi professor de castelhano e literatura em escolas secundárias, no "Instituto Nacional Superior del Profesorado" e na Faculdade de Filosofia e Letras, de cujo Instituto de Literatura Hispano-americana foi diretor a partir de 1955 (Bentivegna, 2017).
} 
versão do Manual de espanhol, de 1945, colocando-os aqui em uma série com os das outras duas obras, escritas dois anos antes por Idel Becker.

Os paratextos da trilogia: as projeções da língua e dos destinatários

Genette se refere às instâncias prefaciais como o discurso produzido a propósito do texto que segue (ou antecede) (2009, p. 145). Essas instâncias funcionam, assim, como uma espécie de anúncio do que encontraremos no interior, sendo, segundo esse mesmo autor, uma “declaração de intenções” (ibid. p. 196). De forma mais específica, podemos pensar que esses sujeitos do discurso que se mostram nas instâncias prefaciais de livros que abordam questões linguísticas e culturais (seja o autor escrevendo um prólogo, ou o editor ou apresentador fazendo um prefácio), além de “anunciar” em certa medida a "intenção" do livro para o leitor, deixam transparecer as concepções e representações sobre a(s) língua(s). Daí, a proposta de analisarmos os textos programáticos da trilogia. Mais do que uma abordagem linear que percorra cada paratexto, propomos uma análise pendular que nos permita reconhecer nessas materialidades específicas a emergência de certos tópicos e regularidades. Que ideias e representações sobre a(s) língua(s) e sobre os destinatários tinha esse autor cuja subjetividade estava constituída de maneira especial pelo espanhol (como uma de suas “duas línguas maternas” nas palavras de Giusti)? Quais são as marcas que funcionam como indícios dessas projeções?

Se, seguindo as reflexões de Courtine (2009, p. 111), tomarmos esses paratextos como um domínio de atualidade, num corte sincrônico que os instala como pontos datáveis (1943, 1945) e referenciais a um sujeito enunciador (Idel Becker), encontraremos neles traços de discursos anteriores (estamos pensando especialmente, mas não só, na Gramática de Nascentes de 1920) que permitem visualizar o funcionamento de uma memória já constituída num recorte anterior. Courtine afirma que essa sucessão cronológica é atravessada "pela dimensão temporal específica a um processo cujo desenvolvimento contraditório não conhece sujeito, nem origem, nem fim” (2009, p. 111). Trata-se da historia, necessariamente contraditória, afetando os objetos e o sujeito em questão. O próprio Courtine deixa claro que não está falando de uma sequencialidade “do antes, do agora e do depois”:

Não se trata, pois, de ir procurar na seqüencialidade de um domínio de memória, de um domínio de atualidade e de um domínio de antecipação a 
sequência "natural” do antes, do agora, do depois, mas sim, de nele caracterizar as repetições, as rupturas, os limites e as transformações de um tempo processual (2009, p. 111).

É nesse tempo processual que não propõe uma sequencialidade “do antes, do agora e do depois” onde buscaremos rastrear rupturas, repetições e transformações. Deslocamentos que vão marcando a memória sobre a língua e sobre seu ensino. O objetivo nas análises que seguem é levantarmos alguns tópicos que permitem entrever certas ideias, objetivos, projeções e preocupações do autor, assim como traços de uma subjetividade que se mostra na materialidade da língua.

Várias marcas nos permitem afirmar que Becker tinha claro que estava escrevendo o livro para um destinatário específico. O Manual, assim como o Compêndio de Literatura Espanhola e Hispano-Americana que escrevera dois anos antes, foi organizado para os alunos brasileiros dos cursos Clássico e Científico seguindo a orientação geral do Programa de Espanhol vigente (Becker, 1943, p. 17) ${ }^{165}$. Livros específicos para destinatários específicos: os alunos brasileiros. E, nesse sentido, um aspecto que se tornará regular na produção realizada no Brasil por autores brasileiros e que julgamos significativa ${ }^{166}$ : compreender que nesse processo de ensinoaprendizagem o par linguístico em jogo (espanhol e português) tem uma especificidade que torna o espanhol, como afirma Celada (2002), uma língua singularmente estrangeira. Vale lembrar que Nascentes, na Gramática de 1920, já falara dessas especificidades. Esses autores, inseridos em dois momentos diferentes de ensino plurilíngue, tinham percebido, cada um a seu modo, a "singularidade" da língua que estava sendo gramatizada, em relação a um falante de português do Brasil.

De forma especial, nos interessa rastrear as representações sobre a língua e sobre os destinatários, um aluno específico (o brasileiro) competente linguísticamente e um professor projetado com liberdades de escolha e autonomia. Assim se expressa Becker no Manual:

Numa gramática espanhola ${ }^{167}$ - redigida em língua portuguesa ${ }^{168}$, para uso de alunos brasileiros - pareceu-nos acertado deixar de lado, quanto possível,

\footnotetext{
165 As ideias contidas nos paratextos do Manual já tinham sido expressas, em parte, dois anos antes, na elaboração do Compêndio. Nesse livro de 1943, o primeiro dos textos programáticos é um Prefácio, escrito em espanhol por Roberto Giusti, o segundo é um Prólogo do autor. No Manual, se mantém o texto de Giusti (agora como Prólogo) e o segundo texto recebe o nome de Prefácio do autor e intercala ideias já expressas com outras mais específicas sobre a língua.

${ }^{166}$ É um aspecto significativo que de diferentes modos atravessa a gramatização brasileira do espanhol e que não está presente nas produções espanholas que entram ao Brasil na virada dos anos 1980 para os 1990.

${ }^{167}$ É interessante esse reconhecimento do autor: o livro era "uma gramática”, embora anunciado pelo seu título como manual. As três primeiras edições, todas de 1945, mantêm esse formato. Pouco tempo depois
} 
áridos aspectos doutrinários e teorias gramaticais de caráter geral. Supõe-se que o aluno já saiba o que é, por exemplo, verbo e o que significam os diversos modos, tempos, números e pessoas (1945, p. 11).

A projeção dos conhecimentos, quando imaginada de forma mais geral, é possível em um programa escolar unificado pelo Estado. No recorte acima, a projeção de um aluno competente linguísticamente justificava deixar de lado os “áridos aspectos doutrinários” e as “teorias gramaticais de caráter geral”. As definições, portanto, ficavam fora "a não ser em casos especiais de divergência de um para outro idioma” (ibid.). O verdadeiro conhecimento da língua derivava, para o autor, dos “aspectos lexicológicos e sintáticos” e a comparação entre as línguas era o modo de fazer "surgir uma compreensão mais nítida da matéria”, cuja base seria a percepção das "analogias e dessemelhanças entre o português e o espanhol”, modalidade de trabalho também proposto por Nascentes, como analisa Celada (2002).

As divergências propostas não são apenas as encontradas entre as duas línguas, mas também, no dizer de Becker, se referem “[às] mais importantes divergências gramaticais entre a Espanha e os países hispano-americanos” abordadas no livro. Com as divergências anunciam-se tensões - entre um centro que historicamente impõe uma normatividade e a diversidade da língua - que serão abordadas de forma mais aprofundada no interior do Manual.

As operações realizadas para levar adiante uma análise contrastiva parecem privilegiar não apenas aspectos metodológicos, mas fundamentalmente 0 desenvolvimento de aspectos cognitivos de aprendizagem. Assim consideradas, as línguas estrangeiras estariam ao serviço de uma formação mais integral dos estudantes. A especificidade do aluno brasileiro aparece novamente expressa quando o autor se refere aos exemplos e às palavras de “especial interesse” para esses alunos:

Nos exemplos, tratamos sempre de apelar a palavras cuja dicção, ortografia ou significado fossem de especial interesse para alunos brasileiros. Muitas delas vêm convenientemente traduzidas e comentadas (ibid.).

Se o autor projetava um aluno específico, também dialogava com um professor autônomo, que aproveitaria as situações para dar explicações que enriquecessem o trabalho: "Nas mãos do professor, esses exemplos poderão sugerir rápidas e úteis explicações léxicas” (ibid.).

\footnotetext{
a produção assume claramente o gênero anunciado no título. Abordaremos essas questões e a transição entre os gêneros no próximo capítulo.

${ }^{168}$ Aqui vale a pena observar que o ensino da língua estrangeira com o suporte de um instrumento linguístico redigido em português (como exigiam as diretrizes do Estado) permite pensar a importância da língua nacional como parte do processo de consolidação do Estados.
} 
“Seguindo as diretrizes do Programa de espanhol”, diz Becker, “quisemos, em suma, fazer gramática viva, prática, adequada realmente aos estudantes brasileiros” (ibid.). Assim, a produção tinha a intenção de responder, organizada em diversas partes, às solicitações do Programa e de suas diretrizes. Segundo o autor, essa organização também tentou deixar o professor mais autônomo no trabalho e com liberdade de escolha, sem a rigidez que uma sequência didática imporia:

A História Literária e a Antologia Espanhola e Hispano-Americana, que
completam o programa da matéria, foram deixadas em lugar aparte.
Entremear a doutrina gramatical com os trechos antológicos - como é de
praxe em muitas obras do gênero - teria sido compelir os professores a uma
determinada e rigorosa seqüência didática, à mercê do gosto e da opinião do
autor. Separadas, porém, ambas as partes, o professor poderá escolher - à
medida que for desenvolvendo os pontos gramaticais - as leituras que achar
mais adequadas ou oportunas (1945, p. 11-12).

As leituras - sempre modelos de língua - poderiam ser escolhidas pelos professores, de acordo à organização dos conteúdos. Não só o aspecto gramatical levava em conta o aluno brasileiro, também a parte antológica teve em foco esse aluno: “a parte antológica - comentada em língua portuguesa - foi especialmente organizada para os alunos brasileiros dos cursos Clássico e Científico”. O autor comenta no Prefácio do Manual que seguiu a orientação geral do programa oficial, apresentando trechos cujo assunto principal fosse “a paisagem e a vida na Espanha e nos países americanos de língua espanhola” (ibid., p. 12.). O Programa, como expressão das diretrizes ministeriais, colocava exigências que a elaboração das obras buscava atender, produzindo nelas transformações significativas. É o caso do Manual, que passa por reformulações que vão tentando se ajustar, cada vez mais, ao discurso ministerial - que trazia propostas mais amplas para o ensino da língua - e à realidade escolar, com uma hora de aula semanal.

Como na Gramática de Nascentes (1920), também na obra de Becker as diretrizes do programa funcionaram como determinações históricas que marcaram o processo de produção, explicitado inclusive pelo autor. Vale lembrar que o espanhol acabava de entrar no currículo do ensino secundário e a adesão às diretrizes do Estado é, como assinalamos acima, uma constante na produção editorial da época e em produções posteriores.

Outro tópico que surge na leitura dos paratextos é a comparação entre as línguas, um procedimento que permitiria que surgissem as "analogias e desemelhanças”, fato que levaria a “uma compreensão mais nítida da matéria”. Assim, a preocupação com as semelhanças/diferenças se apresenta como uma continuidade - lembremos que já tinha 
sido a proposta de trabalho de Nascentes. Numa das obras de 1943 (Dicionário espanholportuguês e português-espanhol, que lemos na edição de 1979, na qual são apresentados os Prefácios das edições anteriores), e do mesmo modo que tinha expressado Nascentes na Gramática de 1920, deixam-se de lados as semelhanças para por o foco nas diferenças que constituem, segundo os autores, as dificuldades mais significativas. Isso implicava ter o contraste entre as línguas como importante ferramenta de trabalho. Assim se expressa o autor sobre essa questão na segunda edição desse dicionário (1951):

Este Dicionário seleciona os termos espanhóis mais importantes para o leitor brasileiro - e para o leitor espanhol ou hispano-americano que deseje falar e escrever em português. Deixa de lado, pois, muitos homógrafos de idêntico sentido em ambos os idiomas e restringe o número de derivados e afins de um mesmo vocábulo (apud Becker, 1979, p. 7).

Com relação às dificuldades e às divergências entre as línguas, diz Becker:

Assinalei as mais significativas dificuldades léxicas e sintáticas, no conhecimento simultâneo dos dois idiomas - sobretudo as divergências gráficas, prosódicas, genéricas e semânticas, a disparidade no regime dos verbos e o uso desigual das preposições (ibid.).

Também se antecipa a proximidade histórica das línguas na península ibérica, desta vez em palavras de Giusti, presentes no paratextos do Manual e do Compêndio

Dos lenguas, el portugués y el español, hermanadas por sus orígenes, su contacto geográfico y la permanente compenetración léxica y literaria. Hubo un tiempo en que todos los trovadores de la península, así fueran castellanos, andaluces o extremeños, versificaban en lengua galaicoportuguesa, hecho corroborado por un texto inequívoco del Marqués de Santillana. El fenómeno inverso se produjo hacia el siglo XVI, cuando el habla de Castilla penetró en la corte de Lisboa, como puede verse por el Cancionero de García de Resende. Gil Vicente, Sá de Miranda, en ocasiones el propio Camões, fueron bilingües (Giusti, apud Becker, 1945, p. 7).

Nesse fragmento abordam-se diversos aspectos relacionados à proximidade das línguas: a origem, o contato geográfico e a permanente compenetração léxica e literária. Reconhece-se nesse recorte a "língua comum" usada pelos trovadores de diferentes regiões para versificar: primeiro, a língua galaicoportuguesa e, no século XVI, a fala de Castilha que penetrando a corte de Lisboa permitiu a expansão da língua e o reconhecimento de marcas de bilinguismo.

No parágrafo seguinte, essa história linguística do português e do espanhol na península do século XVI é transportada à América e, de forma mais específica, aos falantes das línguas e à identificação do povo argentino e brasileiro nos destinos do continente:

Dos pueblos, el brasileño y el argentino, vinculados, cuando no por la historia -la cual, aun en las fricciones y choques que parecen separar, tiende puentes, con certeza por su actual identificación con los comunes destinos de América (ibid.). 
Eram os anos do governo Vargas e essas palavras parecem se alinhar ao projeto do Estado e ao desejo formulado na Exposição de Motivos de 1942 de "uma maior e mais íntima vinculação espiritual com as nações irmãs do continente”. A menção aos dois povos (o brasileiro e o argentino) não só parece retomar o tratado $\mathrm{ABC}$, mas a aproximação (e posterior relação) levada adiante entre Vargas e Perón, embora este último ainda não estivesse na presidência da República Argentina. Colocando numa relação próxima língua e política, a especificação desses dois povos - brasileiro e argentino - com “los comunes destinos de América” funcionava como justificativa para o estudo das duas línguas em ambos os países:

De ahí la imperiosa necesidad de conocernos mejor, tarea emprendida en los
últimos años con tan buena voluntad de ambas as partes. Uno de los medios
más eficaces para conseguirlo será el recíproco estudio de las magníficas
literaturas de ambas lenguas peninsulares, prolongadas y vivificadas en el
suelo americano. Ese propósito se ha impuesto el colector de la presente
Antología, el doctor Idel Becker (ibid.).

Havia que "se conhecer melhor" e um dos meios mais eficazes para esse conhecimento seria o estudo das "magníficas literaturas de ambas línguas peninsulares, prolongadas e vivificadas en el suelo americano”. Já Becker, no Prólogo do Compêndio (1943) e no Prefácio do Manual (1945), em palavras em que a subjetividade (atravessada por duas línguas) se mostra de forma clara, dá contornos ao espaço latinoamericano afirmando que o livro "resume veementemente anseios pessoais de fraternidade latino-americana”, “ele sublima nossa dedicação, de igual fervor, a ambas as culturas - lusa e hispânica (Becker, 1943, p. 17; 1945, p. 12).

No último recorte de Giusti transcrito acima, reconhecemos outra continuidade nesse tempo processual: a necessidade de um melhor conhecimento que, segundo ele, se daria por meio do estudo da literatura e, segundo Nascentes, na Gramática de 1920, pelo conhecimento “não perfunctório” da língua. Segundo Giusti, a tarefa foi empreendida naqueles anos con “buena voluntad de ambas as partes”. Reconhecemos aí a referência ao empenho dos respectivos Estados, e reconhecemos, mais uma vez, o lugar de destaque dado à escola nessa proposta de ensino das línguas e das literaturas. A escola continuava sendo o lugar para estudar as línguas estrangeiras.

Sobre a diversidade da língua espanhola, embora se reconheçam certas particularidades do espanhol falado em América - avançando numa suave erosão de uma norma central -, também são assinalados barbarismos, arcaísmos e neologismos, uma parte da língua que, como refletimos no capítulo anterior, fica fora da língua e 
permite vislumbrar certo centro com relação ao dispositivo normativo. Quais seriam os arcaísmos e em relação a que "atualidade” da língua poderiam ser definidos? Afinal, se afirmarmos que um dizer é arcaico, ele será arcaico com relação a outro que já foi dito em outro momento ou em outro espaço geográfico ou com relação a um neologismo que convive e se intercala com ele.

Esses aspectos parecem indícios da permanência de um centro normativo, mesmo reconhecendo certos deslocamentos com relação a ele, tanto em 1920 como nas obras produzidas nos anos do governo Vargas. No Prefácio da segunda edição do Dicionário (1951), o sujeito da linguagem deixa transparecer da seguinte forma a tensão entre a presença desse centro e a suave erosão produzida pela sensibilidade para o caráter heterogêneo da língua:

Emfim, arrolei diversas questões gramaticais (leísmo, seseo, voseo, yeísmo, etc.), vícios de sintaxe, barbarismos (especialmente galicismos e anglicismos), arcaísmos, neologismos, etc. - com os correspondentes esclarecimentos e quando necessário, com as correções (e/ou alternativas) julgadas oportunas e adequadas (apud Becker, 1979, p. 7, itálico do autor, negritas nossas).

Junto às modalidades que apresentam um funcionamento diverso da língua, os "vícios de sintaxe” e os “barbarismos”, emanados de uma norma central ${ }^{169}$.

A concordância, de modo geral, com a Real Academia Espanhola, que apontava à unidade da língua, não impedia Becker de discordar por vezes não só dessa instituição, mas também de autores de renome. Na terceira edição do Dicionário (1961) isso é exposto de forma clara. Citando palavras de Giusti, Becker afirma:

Uniformarse a la ortografía académica, cualesquiera sean sus defectos, es de mucha conveniencia práctica para todos los pueblos del habla castellana, así como lo es la adopción de un mismo vocabulario y de normas sintácticas comunes, salvando en lo primero y en ocasiones en lo segundo, las diferencias regionales y los fueros individuales de escritores cuyo ejemplo puede hacer autoridad. La anarquía en la escritura sería un peligro para la unidad lingüística hispanoamericana, don precioso que todos debemos mantener (ibid.).

Manter a unidade da língua foi uma preocupação emanada, não só a partir da RAE, com relação ao mundo hispânico e com relação também ao ensino da língua como estrangeira (como apresentaremos no próximo capítulo), mas também presente nos primeiros instrumentos linguísticos produzidos na América após as independências dos Estados Nacionais, como apresentado no capítulo 2.

169 A sintaxe da enumeração apaga a diferença, a distância entre os elementos presentes, uma marca da tensão já assinalada. 
Na edição do Dicionário de 1961 que estamos analisando, Becker afirma que “aun cuando haya más de un punto discutible, en la mayoría de los casos uno puede concordar con la Academia Española”, justificando tal afirmação do seguinte modo:

Sus casi 250 años de honesta, tesonera y nutrida labor -gramatical, lexicográfica y literaria- merecen el acatamiento y la gratitud de todos los hispanohablantes (apud Becker 1979, p. 7).

O autor do Dicionário reconhece, por meio de palavras de Angel Rosenblat a extraordinária tarefa realizada pela Academia em seus dois séculos de vida: "Hay que reconocer que la Academia Española, en sus dos siglos de vida, ha realizado una labor extraordinaria. Por eso el mundo hispánico está atento a sus preceptos (...)” (ibid., p. 8). Mas nesse terreno de reiterações e continuidades, ao mesmo tempo em que se afirma esse lugar hierárquico dado a Academia (como, lembremos, aconteceu na Gramática de Nascentes), se desenha um terreno em que a língua se apresenta como um campo de controvérsias e de opiniões diversas (também suavemente presente na obra de 1920):

Todo ello [a tarefa extraordinária realizada pela RAE], sin embargo, no nos impide discordar a veces de la Academia y de autores de renombre. Este diccionario es obra personal y yo no quise -ni debía- deshacerme de mi criterio propio (ibid.).

E a continuação dá uma série de exemplos nos quais discorda da acentuação proposta pela Academia para certas palavras. O autor fala em não “regatear aplausos” (dados à Academia) e em “por reparos” às prescrições, sempre que “nuestra convicción personal lo juzgue necesario” (ibid.). Assim, arriscaríamos dizer que começa já com a produção do Manual (1945) e reforçado nas edições posteriores do Dicionário um trabalho lento e sutil de erosão das prescrições. Becker (1961) manifesta de forma explícita os vaivens entre as convicções pessoais e ceder à doutrina da Academia para a preservação da "língua comum":

\footnotetext{
Hay en mis razones personales tanto deseo de acertar y de conciliar el bien común, como en el que más. Que si en uno u otro punto no dejo de lado mi íntima convicción, en muchísimos he cedido ante la doctrina de la Academia (aunque no siempre enteramente convencido), en aras de los supremos intereses de una lengua común, hablada en 20 naciones por más de 160 millones de habitantes -el mayor imperio lingüístico (después del inglés) entre los idiomas de Occidente (apud Becker 1979, p. 8).
}

As tensões entre as "convicções" do autor e a adesão a uma norma central representada pelos quase 250 anos de existência da RAE e da sua "honesta, tesonera y nutrida labor gramatical, lexicográfica y literaria-“ se alinham com as ideias, debates e disputas de época que apresentam essas oscilações entre uma língua comum, constitutiva dessa 
nação americana que era a Pátria Grande e, ao mesmo tempo, constitutiva das ideias do hispanismo (Sepúlveda, 2005) - que reaproximavam à Espanha das nações da América hispânica -, e uma política independentista ${ }^{170}$. A língua comum era um valor para a manutenção da unidade.

As análises empreendidas no próximo capítulo terão presente, dentre outras questões, aspectos da biografia do autor e as representações sobre a língua analisadas nesta seção como parte das condições de produção. Um autor marcado pela própria experiência de aprendiz, na Argentina, e pela experiência pedagógica rioplatense vivida especialmente com Roberto Giusti, uma pessoa que deixou suas marcas nas produções de Becker de 1943 e de 1945.

Neste capítulo estudamos aspectos das condições de produção que tem efeitos na elaboração de instrumentos linguísticos de espanhol a partir de 1942. Inicialmente, nos detivemos na incorporação da língua espanhola no currículo dos estudos secundários, como efeito da Reforma Capanema (1942), interpretando que tal incorporação esteve vinculada à aproximação que o governo Vargas buscou estabelecer com os países da região. Também identificamos que o Programa colocava novas exigências para o ensino da língua e que essas representações ampliadas tiveram efeito no processo de gramatização: as gramáticas escolares já não davam conta das demandas ministeriais, surgindo nesses anos o manual como gênero de discurso com suas especificidades. Finalmente, estudamos aspectos da biografia da Becker que deixam marcas nas representações sobre as línguas, sobre a relação entre elas e o trabalho com elas e na produção do próprio Manual. Assim, este capítulo abordou questões importantes das condições sócio-históricas de produção do instrumento linguístico que analisaremos no próximo capítulo: Manual de español (1945) e suas reformulações.

\footnotetext{
${ }^{170}$ Adentraremos nessas questões no próximo capítulo. Aqui fazemos apenas um anuncio.
} 


\section{CAPÍTULO 4}

Reformulação interdiscursiva: as três versões do Manual de espanhol (1945, 1947, após 1961) 
No capítulo anterior apresentamos uma rede complexa de condições de produção que nos permitirão realizar uma leitura mais aprofundada do Manual de Espanhol, tentando entender como a história e, de forma mais específica um projeto político, a expansão do ensino secundário e do mercado editorial e a circulação dos conhecimentos sobre as línguas se fazem presentes na materialidade do livro e nas reformulações realizadas pelo próprio autor em um curto período de tempo. Ou seja, tentaremos interpretar as marcas que funcionam como indícios das condições de produção, consideradas enquanto historicidade que se inscreve nessa textualidade.

Nos anos iniciais da Era Vargas, é idealizado um projeto educativo nacional que projetava uma educação mais democrática e, especialmente, a ampliação do ensino médio. Ao apresentarmos aspectos da biografia e da formação do autor analisamos os paratextos (escritos por ele e por Giusti) de uma trilogia produzida entre 1943 e 1945. Esse trabalho nos permitiu delinear representações sobre as línguas (sobre a proximidade linguística e histórica e sobre o contraste como forma de trabalho) e sobre os destinatários: um aluno brasileiro competente linguísticamente e um professor com autonomia para fazer escolhas.

Neste capítulo, buscamos identificar como esse projeto educativo mais amplo e formativo dos adolescentes, proposto em 1931 com a Reforma feita por Francisco Campos e renovado com a Reforma Capanema de 1942 - cuja finalidade seria a formação da personalidade adolescente, de uma consciência patriótica e de uma sólida cultura geral -, determina o processo de produção do livro. Para esse percurso cabe perguntar: quais são as marcas que nos permitem compreender possíveis efeitos do discurso ministerial no processo de produção e reformulação do Manual? Ou seja, em que medida as mudanças produzidas a partir do Estado (na legislação e nas diretrizes para o ensino da língua) têm efeitos no Manual de espanhol de Idel Becker e quais são os indícios desses efeitos? Que contornos adquirem a língua e a cultura nesse instrumento linguístico e que projeto educativo e pedagógico - no que se refere especificamente à disciplina língua espanhola - vemos nele projetado? 
É bom lembrar que o Manual passa rapidamente por um processo de reformulação e, nesse processo, o discurso do Estado exerce suas determinações. Tais indícios, por sua vez, assinalam uma transformação no processo de gramatização do espanhol no Brasil, especialmente na produção de instrumentos linguísticos em estreita relação com a dimensão pedagógica e escolar. Mostraremos que as transformações no projeto educativo do Estado afetam tal processo de gramatização e que esse movimento produz deslocamentos com relação à Gramática de Nascentes, de 1920, estudada nos dois primeiros capítulos.

As análises realizadas ao longo do capítulo também buscam lançar luz sobre as reformulações pelas quais passa o instrumento linguístico, que inclusive implicaram numa mudança de gênero. Embora anunciado no título como manual (Manual de espanhol), as primeiras três edições, todas de 1945, se apresentam como gramáticas ${ }^{171}$. Em pouco tempo, uma reorganização dos conteúdos dá ao livro o formato final de manual: a parte gramatical (simplificada) e as leituras têm como fonte essa produção inicial de 1945, existindo todo um processo de seleção e reorganização dos textos e dos tópicos gramaticais. São incorporados também imagens, exercícios e provérbios que dão ao livro, a partir de 1947, o formato definitivo e regular das lições ${ }^{172}$.

O Manual: produção, circulação e reformulações

O Manual de Idel Becker se publica pela primeira vez em 1945 e se reedita (no mínimo) até $1996^{173}$. Foi adotado (dentre outros) na escola secundária após a entrada do espanhol no currículo com a reforma Capanema (1942) e foi utilizado também, passados os anos, em universidades ${ }^{174}$.

A elaboração do Manual não só parece responder a essas novas diretrizes do Estado, mas está atravessada também por certas particularidades da vida do autor, cuja

\footnotetext{
${ }^{171}$ Assim chama a primeira parte do livro: "Gramática Espanhola”. As outras duas partes são: "História literária", dividida em literatura espanhola e literatura hispano-americana e "Antologia”, dividida em Espanha e Hispano-América.

${ }^{172}$ As três primeiras edições, de 1945, apesar do título, respondem ao gênero gramática. A quarta edição não foi encontrada, mas a quinta, de 1947, já tinha mudado o formato. Essa mudança, inclusive, é anunciada pelo autor na carta aos professores que funciona como prólogo, e nos dados da capa em que se apresenta a $5^{\mathrm{a}}$ edição "enteramente refundida y ampliada", fato que nos permite imaginar que a primeira reformulação acontece nesse momento.

${ }^{173}$ É desse ano a última edição que encontramos na nossa pesquisa.

${ }^{174} \mathrm{O}$ próprio Becker dá indícios desse uso, ao comentar sua experiência pedagógica - abordaremos isso adiante. Também Picanço (2003), em entrevistas feitas com professoras de espanhol do Estado do Paraná constata a importância do livro no ensino universitário. Uma das professoras entrevistadas afirma que "foi o livro de texto mais usado na sua formação" (ibid., p. 93).
} 
subjetividade estava constituída pelo português e pela língua espanhola e que se apresentava a si mesmo como um sujeito com uma forte crença na "fraternidade latinoamericana”, e ainda por outras variáveis. Como afirma Tosi ${ }^{175}$ (2018, p. 19, 27, 41), os livros produzidos para a escola secundária são suporte e expressão de saberes acadêmicos, de correntes pedagógicas, de novos métodos, de ideologias institucionais e, também, de uma indústria editorial que vai tentando acompanhar o crescimento da matrícula como efeito da expansão do ensino médio. Uma série de variáveis - não mensuráveis - que entram em jogo na reformulação de um livro, transformações essas que abordaremos, ao longo do capítulo, analisando as diferentes versões da obra e as operações de reformulação.

Para levar adiante essa tarefa, tomamos o conceito de reformulação interdiscursiva de Arnoux ([2006] 2009) ${ }^{176}$. A estudiosa afirma que a diferença da reformulação intradiscursiva - a que se realiza na linha horizontal do dizer -, a interdiscursiva "se realiza a partir de um texto fuente que puede ser del mismo autor", como no caso que estamos abordando, ou de outro, "como las adaptaciones didácticas de un texto clásico” (ibid. p. 97). Arnoux também afirma que esse tipo de operações “permite vislumbrar las representaciones de la nueva situación de enunciación (...) y de las condiciones sociohistóricas de producción de los textos que orientan las operaciones realizadas” (ibid.) que podem consistir em omissões, agregados, substituições ou deslocamentos. Por último, explica que "en algunos casos las reformulaciones son muy próximas discursivamente al texto fuente” e que em outros “la distancia es mayor” (ibid.).

Pelo conceito formulado por Arnoux, especialmente produtivo para a análise do nosso corpus, abordaremos a reformulação interdiscursiva do Manual e transitaremos pelas diferentes versões observando as permanências e as transformações que, inclusive num trabalho expressivo de autoria, levaram a uma mudança de gênero: de gramática a manual. Sendo assim, poderíamos perguntar: que permanece e que muda nessas versões? Quais são as representações e as novas condições socio-históricas de produção que determinam as operações realizadas pelo autor? Em síntese, vamos observar nos textos as marcas que se tornam indícios do modo como o próprio gênero e as condições de produção de cada versão afetam a reescrita da obra.

\footnotetext{
175 A autora aborda os livros de textos da escola secundária como fontes historiográficas. Embora o estudo esteja centrado na realidade argentina, as reflexões resultam inspiradoras e, entendemos, podem ser transpostas para o nosso trabalho.

${ }^{176}$ Arnoux aborda esse conceito ao estudar um caso particular: a série de operações realizadas por Juana Manso - escritora argentina do século XIX - na publicação de novas versões de sua novela Los Misterios del Plata.
} 


\begin{tabular}{|l|l|l|}
\hline \multicolumn{1}{|c|}{1945} & \multicolumn{1}{|c|}{1947} & \multicolumn{1}{c|}{ após 1961 } \\
\hline MANUAL DE ESPANHOL & MANUAL DE ESPAÑOL & MANUAL DE ESPAÑOL \\
$\begin{array}{l}\text { Gramática } \\
\text { Historia literária } \\
\text { Antologia }\end{array}$ & $\begin{array}{l}\text { Gramática. Ejercicios. } \\
\text { Lecturas. Cuestionarios. } \\
\text { Notas Prácticas. Historia } \\
\text { Literaria. }\end{array}$ & $\begin{array}{l}\text { Gramática. Ejercicios. } \\
\text { Lecturas. Correspondencia. } \\
\text { Vocabularios. Antología } \\
\text { Poética. }\end{array}$ \\
$\begin{array}{l}\text { Companhia Editora Nacional } \\
\text { São Paulo, Rio de Janeiro, } \\
\text { Recife, Bahia, Pará, Porto } \\
\text { Alegre }\end{array}$ & $\begin{array}{l}\text { Companhia Editora Nacional } \\
\text { São Paulo, Rio de Janeiro, } \\
\text { Recife, Bahia, Pará, Porto } \\
\text { Alegre }\end{array}$ & $\begin{array}{l}\text { Nobel } \\
\text { São Paulo }\end{array}$ \\
388 páginas & 277 / 301 ${ }^{178}$ páginas & 223 páginas \\
\hline
\end{tabular}

Dados presentes nas capas (título, subtítulos, editora)

As três primeiras edições do Manual de Idel Becker, todas de 1945, compõem a primeira versão da obra, com 388 páginas escritas em português, um investimento de cunho glotopolítico diante das exigências da Comissão Nacional do Livro Didático que, por aqueles anos, exigia que os livros fossem escritos na língua nacional. Essas edições fizeram parte do primeiro movimento de aceleração na produção de instrumentos linguísticos que buscava atender a ampliação do número de alunos que passaram a estudar a língua como efeito da incorporação do espanhol ao currículo. Becker já tinha escrito o Compêndio de Literatura Espanhola e Hispano-Americana e o Dicionário espanhol-português e português-espanhol em 1943 e, pouco tempo depois, em 1945, lança essa terceira obra de fôlego.

A Era Vargas estava terminando. O contexto sócio-político era de continuas pressões e começaram a ser dados os primeiros passos para a redemocratização do país, anunciando-se as eleições presidenciais para o dia 2 de dezembro daquele ano ${ }^{179}$.

A quinta edição, de 1947, já está em espanhol e constitui uma segunda versão ${ }^{180}$, com 277 páginas. Vargas já não estava no governo, porém, continuavam vigentes as

177 Tentando precisar melhor a data dessa última versão, entramos em contato com a Editora Nobel e nos informaram que os títulos que saem de catálogo há bastante tempo (como é o caso do Manual) são enviados para um arquivo morto, ao qual os funcionários não tem acesso. Dessa forma, a data ficou imprecisa neste trabalho. Novas pesquisas talvez possam ajudar a determinar melhor o momento de publicação da terceira versão do Manual.

178 A edição de 1947 tem 277 páginas. Em uma edição de 1953, em outra de 1955 e numa terceira de 1961, o número de páginas passa a ser 301. Isso assinala uma versão que se estabiliza nos anos 50, após a incorporação de uma seção chamada Ejercicios de vocabulario.

179 As possibilidades do triunfo de Vargas eram grandes, diante disso, aceleraram-se as articulações conspiratórias que contaram com o aval do embaixador americano no Brasil. Em 29 de outubro de 1945, Getúlio Vargas foi deposto pelo Alto Comando do Exército. No dia seguinte, o presidente do Supremo Tribunal Federal, José Linhares, assumiu a presidência da República, para transmiti-la, em janeiro de 1946, a Eurico Dutra, o candidato vitorioso nas eleições. (Cepedoc). Disponível em: cpdoc.fgv.br/producao/dossies/AEraVargas1/anos37-45/QuedaDeVargas. Acesso em: maio de 2019. 
exigências do currículo e do Programa de espanhol apresentado no capítulo 3. Existe ainda uma versão final (posterior a 1961), com 223 páginas, que foi reeditada até 1996, sendo assim a que teve maior permanência no plano do ensino da língua. Essa última versão foi produzida após a entrada em vigor da Lei de Diretrizes e Bases (1961), cuja textualidade, segundo Rodrigues (2012, p. 88) “opera um apagamento sobre as línguas estrangeiras que habitavam o espaço escolar até aquele momento por meio da exclusão absoluta desse sintagma na materialidade da lei” ${ }^{181}$. Embora afastada da época em foco, pensamos que é produtivo trazer essa versão e essa época às discussões propostas no trabalho para compreendermos a reformulação produzida nesse contexto específico.

De modo geral, as transformações entre a primeira e a segunda versão revelam um trabalho de autoria na direção de atender as diretrizes ministeriais, os novos métodos e as demandas do mercado editorial como efeito da ampliação da matrícula e da estabilização do manual como gênero escolar.

Ao longo das análises apresentaremos a reorganização e as transformações que levam a um movimento de passagem entre dois gêneros diferentes - a gramática e o manual. Interessados pela dimensão ideológica do instrumento linguístico, focalizamos alguns tópicos e nos perguntamos: quais são as condições de produção que afetam o texto, produzindo omissões, diferenças e mudanças no gênero e na forma? Que jogo de antecipações imaginárias (Pêcheux, [1969] 2010) orienta essas reformulações?

No estudo das operações de reformulação realizadas pelo autor do Manual ao produzir novas versões da obra, focaremos os seguintes aspectos: 1. Gênero e organização: a reformulação composicional e os destinatários, 2. Os paratextos: da palavra própria à palavra alheia, 3. As tensões históricas: entre uma norma central e a diversidade linguística, 4. As lições preliminares: o contraste entre as línguas, 5. As leituras iniciais das lições: Espanha e Hispano-américa, 6. Os provérbios: a projeção do destinatário, 7. Os exercícios: o papel das línguas e dos tópicos gramaticais, 8. As notas explicativas da primeira versão: o que se apaga na redução. A formulação desses aspectos já antecipa os títulos dos oito itens que compõem este capítulo.

180 Não tivemos acesso à $4^{\text {a }}$ edição, publicada entre 1946 e 1947. Com base nas informações de Guimarães (2018), quem afirma que essa edição já estava em espanhol, embora tampouco o pesquisador tenha tido acesso à obra, pensamos que pode ser a que contem a primeira reformulação.

181 A própria pesquisadora observa que pelas determinações da legislação de 1942 e a organização da estrutura escolar a partir dessa normativa, “as línguas estrangeiras encontraram condições legais para subsistir mesmo com a exclusão que a LDB de 1961 operou sobre essa matéria” (ibid. p. 85). Essa "susbsistência" - apesar da lei - também permite compreender a permanência da circulação não só do Manual de Becker, mas de outros instrumentos linguísticos produzidos para o ensino da língua espanhola. 
A análise realizada nos itens 1, 2 e 3 atravessa as três versões. De 4 a 7 o foco está nas duas versões finais, quando a obra já está com a estrutura do gênero manual. O item 8 se concentra em um aspecto específico da primeira versão: as notas explicativas, omitidas na segunda e na terceira, especialmente pelas adequações político-pedagógicas e pela mudança de gênero que implicou numa mudança de estrutura e, como efeito, a omissão das reflexões mais aprofundadas sobre os tópicos gramaticais e sobre os modos como a história penetra na língua. Em cada caso buscamos refletir sobre um aspecto específico e o movimento vai, em certa forma, do macro na direção de um aspecto pontual, tal como acontece em 8, ao abordarmos as notas explicativas. Pelas especificidades do tópico tratado, alguns desses itens trazem reflexões especialmente importantes para compreendermos questões que a pesquisa busca iluminar. É o caso do ponto 3, que aborda as disputas entre uma norma central e a diversidade linguística, e as determinações e transformações que aí participam.

\section{Gênero e organização: a reformulação composicional e os destinatários}

As três primeiras edições do Manual, todas de 1945, se inscrevem no gênero gramática. Como subtítulo, na capa, se pode ler: Gramática espanhola, Historia literária, Antologia. Os paratextos - dos quais nos ocuparemos no próximo item - estão compostos por um Prólogo de Roberto F. Giusti e um Prefácio de Idel Becker. Em seguida, um quadro que leva por título “Difusão da língua espanhola” no qual se apresenta o número de falantes em Europa, Ásia, África, América do Norte, América Central, Antilhas, América do Sul, Oceania, e dos falantes da língua que moram em países de outros idiomas ${ }^{182}$. A continuação, a primeira parte dedicada à Gramática Espanhola, composta por vinte e um capítulos que abordam diversas temáticas e tópicos ${ }^{183}$ a partir de uma divisão clássica dos estudos gramaticais que descrevem a língua e prescrevem sobre a norma ${ }^{184}$.

\footnotetext{
${ }^{182}$ Em nota, pode se ler: “Quadro baseado na tabela de Grandmontagne (reproduzido das gramáticas de Roberto F. Giusti) e reformado de acordo com estatísticas modernas” (Becker, 1945, p. 14).

183 Os vinte e um capítulos levam os seguintes títulos: I Fonologia, II Ortografia, III Divergências lexicológicas, VI Artigo, V Substantivo, VI Adjetivo, VII Pronome, VIII Verbo, XI Advérbio, X Preposição, XI Conjunção, XII Interjeição, XIII Formação de palavras, XIV Concordância, XV Regência, XVI Construção, XVII Sintaxe figurada, XVIII Vícios de linguagem, XIX Arcaísmos e neologismos, XX Idiotismos, XXI Regionalismos. Divergências léxicas entre a Espanha e a América.

${ }^{184}$ Fazemos essa afirmação levando em consideração a reflexão de Asencio quem, citando Bourdieu, afirma que as palavras podem ter "la capacidad de prescribir bajo la apariencia de describir (2004, p.
} 
Nessa parte gramatical da primeira versão são abundantes as notas explicativas para os professores escritas em espanhol (lembremos que o livro está escrito em português) e com letra menor, em sua grande maioria de autoria de Giusti e que não fazem parte das versões posteriores. Essas explicações destinadas aos educadores assinalam o duplo destinatário do livro: aluno-educador, diferenciando os discursos dirigidos a cada um deles com tipografias diferentes.

Após a longa seção dedicada à Gramática Espanhola, as outras partes são: Sinopse da História da Literatura espanhola, Sinopse da História da Literatura hispano-americana, Trechos fáceis em prosa e em verso (para os exercícios preliminares) e Antologia (composta por três partes: Espanha, Geração de 98. Contemporâneos, Hispano-América).

Observa-se uma versão bastante enciclopédica que se alinha ao humanismo do qual falava a Reforma Capanema, especialmente pelo modo aprofundado de propor o estudo da língua e o da história da língua e das literaturas. Para as seções dedicadas à literatura (sinopses e antologia), o autor recupera boa parte do que já estava no Compêndio (1943). Embora alguns aspectos presentes no Programa de espanhol de 1943, como a exercitação e as praticas orais, não estivessem contemplados ainda, vemos um investimento por parte do autor em responder às exigências, propondo um trabalho intenso com as literaturas espanhola e hispano-americana, seja no estudo da história, seja na apresentação da parte antológica.

Em 1947, a reformulação do livro produz uma segunda versão. O Manual passa por transformações que o deixam com outro formato, uma nova organização e construção composicional, uma nova forma de abordar os aspectos gramaticais e mais adaptado aos requerimentos do Programa, incluindo agora a exercitação e o trabalho com a dimensão oral da língua. Nessa versão, os elementos do subtítulo da capa já anunciam as mudanças: Gramática. Ejercicios. Lecturas. Cuestionarios. Notas prácticas. Historia Literaria e em seguida, $5^{a}$ edição enteramente refundida e ampliada. Nos espaços reservados aos paratextos: uma carta de Becker intitulada A los señores profesores e o texto América ${ }^{185}$ do escritor uruguaio Enrique Rodó. O quadro já referido

223). Também Arnoux (1999, p. 40) é clara nesse sentido: "la descripción gramatical tiene una indudable dimensión prescriptiva (al decir lo que es la lengua, el gramático señala también lo que debe ser)”.

${ }^{185}$ América faz parte de El Centenario de Chile - Discurso pronunciado en representación del Uruguay, en la sesión solemne celebrada por el congreso chileno durante las fiestas del centenario, el 17 de septiembre de 1910 -, um dos textos que compõe o livro El Mirador de Próspero (1913). Vale mencionar que no Manual não há nenhuma referência a esse respeito, fato que produz o efeito de ser um texto 
sobre o número de falantes permanece com dados atualizados. Após o quadro, diversos tópicos agrupados nas Lecciones Preliminares e, a continuação, trinta lições regularmente estruturadas. Até a número dezoito, as lições estão compostas por uma leitura, uma série de perguntas a seu respeito num item denominado Conversación, um provérbio, um tópico gramatical e, de modo regular, uma série de exercícios voltados sobre esse tópico específico. Da lição dezenove à trinta, há uma simplificação na composição: uma leitura, as perguntas correspondentes ao item Conversación e um terceiro item, Cuestionario de Literatura. Essa nova estruturação do livro, com lições organizadas de forma regular que incorporam imagens no começo, sem as notas explicativas da versão anterior e com uma redução e simplificação no modo de abordar os tópicos gramaticais, parece se alinhar às regularidades do gênero manual. Após as lições, outra seção denominada Apéndice Gramatical na qual é ampliado o espectro de tópicos já abordados e Notas práticas ${ }^{186} \mathrm{e}$, a continuação, uma parte reservada à Historia de la Literatura Española, sinopsis y Sinopsis de la historia literaria hispanoamericana. Finalmente: Lecturas suplementares de autores españoles e hispanoamericanos.

A versão final, posterior a 1961, apresenta uma estrutura bastante próxima à de 1947. Algumas modificações no subtítulo assinalam omissões: Gramática. Ejercicios. Lecturas. Correspondencia. Vocabulários. Antología poética. No espaço dedicado aos paratextos, uma carta de Ramón Menéndez Pidal (diretor da RAE) dirigida ao autor da obra e o texto de Rodó - América - presente na versão anterior. O quadro com o número atualizado de falantes permanece. As trinta lições da segunda versão se reduzem a dezoito, mudança significativa que abordaremos mais adiante. Como na

independente, com o seu título (América). No entanto, é apenas um recorte de dois parágrafos do texto mencionado. Trabalharemos sobre esse efeito no próximo item, ao abordarmos os paratextos.

${ }^{186}$ Essas notas abordam estruturas para: saludos familiares, para enterararse de la salud y de la familia del interlocutor, assim como, fórmulas de despedida, de cortesia, fórmulas para agradecer. Aborda-se também o tempo: dias de la semana, meses del año, estaciones. E, finalmente, apresentam diversos modelos de correspondência: billetes y esquelas, tarjetas, cartas comerciales, correspondencia general, solicitudes, dedicatórias. Entre a edição de 1947 que instala uma segunda versão e a última (posterior a 1961) há uma transição na qual vão acontecendo transformações: muda o número de páginas pela incorporação da seção. É uma versão que se estabilizada nos anos 50, até chegar na versão final. Por exemplo, na edição de 1953 existe uma seção chamada Ejercicios de vocabulario que apresenta vinte temáticas diferentes e específicas e que não estava incluída em 1947: $1^{\circ}$ Fórmulas de cortesía. Un encuentro; $2^{\circ}$ La clase de español; $3^{\circ}$ La familia; $4^{\circ}$ Días de la semana. Meses; $5^{\circ}$ Las estaciones; $6^{\circ}$ Los colores; $7^{\circ}$ La casa (el hogar); $8^{\circ}$ Los vestidos, el traje, el vestuario; $9^{\circ}$ La comida, los alimentos; $10^{\circ} \mathrm{El}$ cuerpo humano; $11^{\circ}$ Oficios y profesiones; $12^{\circ}$ Industria y Comercio; $13^{\circ}$ Medios de transporte; $14^{\circ}$ La ciudad; $15^{\circ}$ El campo; $16^{\circ}$ Los animales; $17^{\circ}$ Los vegetales; $18^{\circ}$ Los minerales; $19^{\circ}$ Deportes y diversiones; $20^{\circ}$ Vida Moral, social y cívica. Também há uma regularidade nesses vinte ejercicios de vocabulario: após um breve texto se solicita aos alunos a realização de uma versão ao castelhano, logo uma tradução cujo objetivo é o trabalho com os heterosemânticos e, ainda, a leitura de adivinanzas e a presencia de refranes, provérbios, adágios, em alguns casos e sentencias, máximas, aforismos em outros. 
versão de 1947, antes dessas lições há uma breve introdução dedicada às Lecciones Preliminares e após as 18 lições há outra chamada apenas Apéndice Gramatical; desaparece a especificidade de Notas prácticas. Segue uma breve seção com modelos de correspondência - Modelos de billetes y esquelas, Modelos de tarjetas, Modelos de cartas comerciales y correspondencia general. Em seguida, a seção Ejercicios de vocabulario, que apresenta as temáticas já apresentadas em nota. Finalmente, uma última seção: Breve Antología Poética de autores españoles e hispanoamericanos.

O quadro abaixo completa o já apresentado e permite visualizar mais claramente as mudanças e as permanências, seja nos subtítulos, nos paratextos ou nas seções que compõem cada uma das versões:

\begin{tabular}{|c|c|c|}
\hline 1945 & 1947 & após 1961 \\
\hline MANUAL DE ESPANHOL & MANUAL DE ESPAÑOL & MANUAL DE ESPAÑOL \\
\hline $\begin{array}{l}\text { Gramática } \\
\text { Historia literária } \\
\text { Antologia }\end{array}$ & $\begin{array}{l}\text { Gramática. Ejercicios. } \\
\text { Lecturas. Cuestionarios. } \\
\text { Notas Prácticas. Historia } \\
\text { Literaria. }\end{array}$ & $\begin{array}{l}\text { Gramática. Ejercicios. } \\
\text { Lecturas. Correspondencia. } \\
\text { Vocabularios. Antología } \\
\text { Poética. }\end{array}$ \\
\hline $\begin{array}{l}\text { Companhia Editora Nacional } \\
\text { São Paulo, Rio de Janeiro, } \\
\text { Recife, Bahia, Pará, Porto } \\
\text { Alegre }\end{array}$ & $\begin{array}{l}\text { Companhia Editora Nacional } \\
\text { São Paulo, Rio de Janeiro, } \\
\text { Recife, Bahia, Pará, Porto } \\
\text { Alegre }\end{array}$ & $\begin{array}{l}\text { Nobel } \\
\text { São Paulo }\end{array}$ \\
\hline 388 páginas & 277 / 301 páginas & 223 páginas \\
\hline $\begin{array}{l}\text { - Prólogo (Roberto Giusti) } \\
\text { - Prefácio (Idel Becker) }\end{array}$ & 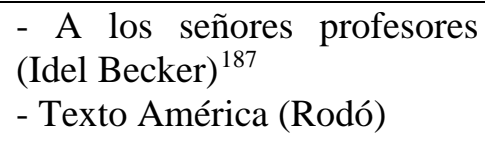 & $\begin{array}{l}\text { - Carta de Menéndez Pidal } \\
\text { - Texto América (Rodó) }\end{array}$ \\
\hline $\begin{array}{l}\text { - Gramática Espanhola } \\
\text { (vinte e um capítulos) } \\
\text { - História Literária } \\
\text { Literatura Espanhola } \\
\text { Literatura Hispano-Americana } \\
\text { - Antologia } \\
\text { Espanha } \\
\text { Geração de 98.Contemporâneos } \\
\text { Hispano-América }\end{array}$ & $\begin{array}{l}\text { - Lecciones Preliminares } \\
\text { - } 30 \text { Lecciones } \\
\text { - Apéndice gramatical } \\
\text { - Notas prácticas } \\
\text { - Ejercicios de vocabulario (1953) } \\
\text { - Historia de la literatura española } \\
\text { - Historia de la literatura } \\
\text { hispanoamericana } \\
\text { - Lecturas suplementares (de } \\
\text { autores españoles e } \\
\text { hispanoamericanos) }\end{array}$ & $\begin{array}{l}\text { - Lecciones Preliminares } \\
\text { - } 18 \text { Lecciones } \\
\text { - Apéndice Gramatical } \\
\text { - Correspondencia } \\
\text { - Ejercicios de vocabulario } \\
\text { - Breve antología poética } \\
\text { de autores españoles e } \\
\text { hispanoamericanos }\end{array}$ \\
\hline
\end{tabular}

Capa com título e subtítulos, paratextos e partes que integram cada versão

O quadro permite acompanhar de forma ampla o teor das reformulações. Dois gêneros diferentes, um único autor, um mesmo ideal, mas plasmado com certas omissões, modificações, sínteses, modalizações e reduções.

${ }^{187}$ A partir de alguma edição que não conseguimos identificar, a carta aos professores é retirada do livro. Em 1953 já não estava presente. Em seu lugar, uma dedicatória a três "maestros": Don Roberto Giusti, Don Angel Valbuena Prat, Don Ramón Menéndez Pidal. 
A mudança na estrutura e organização, na extensão da obra (388, 277 (301) e 223 páginas respectivamente nas três diferentes versões), nos subtítulos de cada versão e na passagem da gramática para o manual são todas variáveis que funcionam como indícios das condições de produção: por um lado, um discurso ministerial que seja na Reforma Capanema ou por meio do Programa específico da disciplina exigia leituras, uma prática oral da língua, o estudo das literaturas e a formação mais ampla dos adolescentes, com base numa sólida cultura geral e, por outro, a projeção de um tipo de falante/usuário da língua, diferente em cada uma das versões e a realidade do pouquíssimo tempo de aula atribuído à disciplina. A última delas apresenta-se mais instrumental: com uma abordagem cultural que passa da Historia Literária a uma Antologia Poética (um compilado do Canon) e com a omissão das perguntas sobre as leituras e dos questionários de literatura. Os vinte e um exercícios de vocabulário também são simplificados, embora sejam mantidas as temáticas.

Duas observações mais gerais são importantes. Uma tem a ver com o docente. Na primeira versão, há toda uma estrutura gramatical e notas especialmente escritas para o docente, quem deveria pensar e organizar todo o trabalho das aulas. A partir da segunda versão (“manual”), as lições estruturam o trabalho (supondo um docente que precisa desse apoio), trazendo outros subgêneros (imagens, provérbios, exercícios, leituras, traduções, questionários) que somam elementos para a formação dos jovens. A outra observação se refere às continuas adequações às diretrizes ministeriais. Na segunda versão já estão presentes as leituras iniciais, os exercícios, o trabalho oral com a língua, aspectos ausentes na primeira e requeridos pelas directrizes do Programa.

\section{Os paratextos: da palavra própria à palavra alheia}

No final do capítulo 3 analisamos os paratextos da primeira versão (1945) em relação aos de outras duas obras escritas por Becker dois anos antes. Agora, retomamos alguns aspectos para estabelecer uma nova série de análise integrada pelos paratextos das outras duas versões do Manual. Sem fazer referência à norma, esses textos introdutórios de 1945 (o Prólogo de Giusti e o Prefácio de Becker) apresentavam uma série de antecipações: um aluno específico - brasileiro e competente linguísticamente -, um professor autônomo e com liberdade para escolher caminhos, um trabalho linguístico que privilegia o contraste entre as línguas e um autor que se projeta a si 
mesmo acreditando veementemente na fraternidade latino-americana. Com relação a essa última projeção, vale lembrar que Giusti se refere a dois povos, o brasileiro e o argentino, vinculados menos pela sua historia - que "aun en las fricciones y choques que parecen separar, tiende puentes” (1945, p. 7) e sim, “con certeza por su actual identificación con los comunes destinos de América” (ibid.). Parece ressoar nas palavras do gramático argentino um ideário de época, reflexões projetadas por Perón e por Vargas em anos próximos àqueles ${ }^{188}$. Era essa “identificación” com os destinos de América o fato que tornava "imperiosa” a necessidade de ambos os povos se conhecerem melhor e o estudo das literaturas era um "meio eficaz" ${ }^{189}$. Nesse mesmo Prólogo, Giusti também apresenta o autor do livro como um homem de duas almas conciliadas para superarem diferenças e contradições ${ }^{190}$. Como disse o gramático argentino, uma vida - a de Becker - desenvolvida entre duas culturas e um sujeito atravessado por duas línguas maternas ${ }^{191}$. Após a apresentação do autor, é a vez da obra: uma empresa idealista - já que busca "fraternizar las dos culturas latinas de América"

\footnotetext{
${ }^{188}$ Maceyra (1984, p. 89) assinala que "una de las piezas angulares de la política latinoamericana trazada por Perón era Brasil, siendo Chile la restante [...]. De acuerdo con esta concepción, Perón había establecido durante su primer gobierno acuerdos con Getúlio Vargas y Carlos Ibáñez, futuros presidentes de Brasil y Chile [...]. Con ambos había acordado impulsar tratados de unión económica, el primero de los cuales debía ser suscripto con Brasil. Sin embargo, dificultades políticas internas -y, posiblemente, presiones externas- demorarían el cumplimiento de lo previsto por parte de Brasil. En vista de ello, Perón -previa comunicación a Vargas y con su anuencia- adoptó la iniciativa respecto de Chile". Mais adiante complementa: "Sorpresivamente el acuerdo (con Chile) fue recibido con duras críticas en la cancillería brasileña, en abierta contradicción con la posición asumida en los contactos extraoficiales sostenidos entre Vargas y Perón. Aparentemente, el presidente de Brasil era presa de fuerzas internas que no dominaba. Según la postura de Itamaraty, los pactos regionales destruían la unanimidad panamericana. Sin duda pesaba en Brasil la influencia de los planes norteamericanos, que concebían la unidad continental en torno al prevalente papel de aquel país, así como la histórica vocación hegemónica de los grupos de poder locales" (ibid., p. 90). Na mesma direção, também Justo (1983) comenta o olhar que Perón tinha sobre a unidade latino-americana, apresentando recortes dos artigos publicados no periódico oficial "Democracia" (com o pseudônimo Descartes). Em um deles, Perón fazia referência ao antigo tratado ABC, afirmando que havia sucumbido: "abatido por los trabajos subterráneos del imperialismo empeñado en dividir e impedir toda unión propiciada o realizada por los `nativos' de estos países `poco desarrollados' que anhela gobernar y anexar, pero como factorías de `negros y mestizos'. E, em seguida, continuava: "Ni Argentina, ni Brasil, ni Chile aislados pueden soñar con la unidad económica indispensable para enfrentar un destino de grandeza. Unidos, forman, sin embargo, la más formidable unidad, a caballo sobre los dos océanos de la civilización moderna. Así podrán intentar desde aquí la unidad latinoamericana con una base operativa polifásica, con inicial empuje indetenible. Desde esa base podría constituirse hacia el norte la Confederación Sudamericana” (apud Justo, p. 45). Por sua vez, Abelardo Ramos (1968) menciona que nos primeiros discursos, Vargas deixa transparecer que percebia a existência de Brasil no contexto da América Latina.

${ }^{189}$ Vale lembrar que esse texto de Giusti já tinha aparecido como Prefácio do Compêndio de Literatura Espanhola e Hispano-Americana (1943), de Becker.

190 "Pocos estudiosos mejor preparados para la imperiosa tarea. Si el alma brasileña y la argentina son diferentes, de él podremos decir que es un hombre de dos almas. No combatidas entre sí, sino conciliadas para superar diferencias y contradicciones” (apud Becker, 1945, p. 7-8).

191 "Bien puede decirse que el portugués y el español son en el mismo grado sus lenguas maternas" (ibid.).
} 
(ibid, p. 8) $)^{192}$ - e um livro composto com critério educativo ${ }^{193}$. Para finalizar, um desejo para que pudesse surgir um livro assim na Argentina: "Espero que en mi patria otro estudioso, que como Becker sienta vivamente el espíritu de las dos culturas, nos dé una antología semejante de las literaturas portuguesa y brasileña” (ibid., p. 9).

Alguns aspectos do Prefácio do próprio Becker também são significativos para compreendermos os textos programáticos da primeira versão. O Prefácio começa reconhecendo o gênero da obra e o aluno específico:

Numa gramática espanhola - redigida em língua portuguesa, para uso de alunos brasileiros - pareceu-nos acertado deixar de lado, quanto possível, áridos aspectos doutrinários e teorias gramaticais de caráter geral (Becker, 1945, p. 11, itálico nosso).

Na segunda página isso aparece reforçado: “A parte antológica - comentada em língua portuguesa - foi especialmente organizada para os alunos brasileiros dos cursos Clássico e Científico” (ibid. p. 12). Além de um aluno brasileiro, as projeções imaginárias também antecipam um aluno competente linguísticamente:

Supõe-se que o aluno já saiba o que é, por exemplo, verbo e o que significam os diversos modos, tempos, números e pessoas. Excusam-se, portanto, as respectivas definições, a não ser em casos especiais de divergência de um para outro idioma (ibid.).

O método de trabalho também aparece expresso, a comparação e o contraste que faziam parte dos métodos mais reconhecidos no ensino das línguas estrangeiras aparecem anunciados:

dentro do possível, adaptamos nossa exposição, à lexicologia e sintaxe portuguesas, comparando sempre, para que das analogias e dessemelhanças entre o português e o espanhol, possa surgir uma compreensão mais nítida da matéria (ibid.).

A sensibilidade e experiência do autor com as duas línguas e com a prática docente permitem que prefigure um lugar de complexidade para a relação entre elas, identificando esse “entremeio" (Celada, 2002) que o reconhecimento das "analogias e dessemelhanças” contribuiria a separar, para que “[pudesse] surgir uma compreensão mais nítida da matéria”.

\footnotetext{
192 "El presente libro también es una empresa idealista, pues se propone hacer fraternizar las dos culturas latinas de América” (ibid.).

193 "Es además un libro ameno, compuesto con criterio educativo, pues mira, no sólo a historiar mediante ejemplos forzosamente fragmentarios, el desenvolvimiento histórico de las literaturas de lengua española, sino a ilustrar al alumno, valiéndose de trozos hábilmente escogidos, sobre el paisaje, las empresas, los sentimientos e ideales de las naciones que dieron vida a aquellas” (ibid. p. 8-9).
} 
O livro também projeta um professor autônomo. Ao se fazer referência à seleção das palavras, afirma-se: "nas mãos de professores, esses exemplos poderão sugerir rápidas e úteis explicações léxicas” (ibid.). Também há uma explicação sobre a presença das “notas adicionais”, “especialmente destinadas aos professores” e “escritas em língua castelhana”, que “esclarecem pormenores ou pontos de vista pessoais” (ibid.).

Outro aspecto presente é o anuncio do livro estar alinhado às diretrizes do Estado, que não só foi uma constante nas diversas obras publicadas pelo autor, mas também nas publicadas por outros autores nesse momento inicial da entrada do espanhol no currículo do ensino secundário:

Quisemos, em suma - seguindo as diretrizes do PROGRAMA DE ESPANHOL - fazer gramática viva, prática, adequada realmente aos estudantes brasileiros (ibid.).

Esse aspecto é retomado ao se fazer referência à parte antológica:

seguiu-se a orientação geral do programa oficial, apresentando-se trechos cujo assunto principal é ‘a paissagem e a vida na Espanha e nos países americanos de língua espanhola' (ibid. p. 12, itálico do autor) ${ }^{194}$.

Após os agradecimentos especiais a Giusti "pelas sabias lições e o generoso estímulo”, são trazidos à tona os "veementes anseios pessoais de fraternidade latinoamericana”, resumidos - segundo ele - no livro, que é “fruto do profundo carinho votado aos idiomas de Cervantes e Camões” (ibid.). O livro sublima, diz o autor, a sua dedicação “de igual fervor a ambas as culturas - lusa e hispânica”.

Como vemos, os paratextos da primeira versão de modo geral apresentam alguns aspectos da história da língua, da importância do livro, do método que estrutura o trabalho, do alinhamento com as diretrizes do Estado, da projeção dos destinatários, da identificação dos povos (brasileiro e argentino) com os destinos da América e da história do autor, cuja subjetividade estava atravessada por contextos culturais e linguísticos diversos e cujos anseios pessoais, tal como registrado no Prólogo, incluíam a "fraternidade latino-america" e um "fervor" por ambas as culturas.

Ao analisarmos a segunda versão do Manual, a primeira mudança significativa, após a dos subtítulos, é a modificação dos textos programáticos: já não estão presentes o Prólogo de Giusti e o Prefácio de Becker das edições de 1945. Em seu lugar há uma

\footnotetext{
${ }^{194}$ E complementando, Becker afirma: "Foram acrescentados `excertos dos maiores escritores espanhóis e hispano-americanos': seleções poéticas de essencial valor artístico ou bibliográfico e fragmentos em prosa, quer notáveis pela forma ou pelo sentido, quer sugestivos pela projeção literária do autor, quer ainda de especial interesse léxico ou temático para leitores brasileiros” (ibid.).
} 
missiva do autor dirigida “A los señores profesores” e o texto "América” do escritor uruguaio Enrique Rodó.

Algumas ideias centrais norteiam a carta dirigida aos professores. Por um lado, já no começo, anuncia-se uma aproximação a uma obra que o magistério e as necessidades do ensino reclamavam:

\begin{abstract}
Al incorporar este libro a la producción didáctica brasileña, creo haberme aproximado, un poco más, a la obra ideal -y, por lo tanto, inalcanzable-, que el magisterio y las necesidades de nuestra enseñanza reclaman” (Becker, 1947, p. 10).
\end{abstract}

Opera aí uma projeção da própria obra e do lugar dentro da série didática produzida após a Reforma Capanema. Além disso, o autor afirma que embora tivesse sido composta sobre a base do "primitivo Manual”, a obra que estava apresentando era, em grande parte, “obra nueva”. A continuação, são sinalizadas algumas das principais mudanças:

el texto está, ahora, enteramente redactado en castellano; ello sin duda, favorecerá la labor en el aula. Por otra parte, se le ha dado mayor agilidad y sentido práctico, mediante un conjunto seleccionado de lecturas y ejercicios adecuados” (ibid.).

Vargas já não estava no poder e as exigências para que os livros fossem escritos na língua nacional pareciam ser menos rígidas. Além disso, a “mayor agilidad”, o "sentido práctico", a seleção de "lecturas y ejercicios adecuados” também parecem projetar um trabalho mais prático. Na primeira versão, mais enciclopédica e humanística, não havia a organização nem a exercitação desta segunda que trazia o trabalho de alunos e professores "mais preparado e organizado".

As leituras e os exercícios sobre o tópico trabalhado na lição, junto com a incorporação de imagens, provérbios, perguntas específicas e uma ampla regularidade das lições são aspectos que contribuem na configuração do novo gênero.

Faz-se presente também um modo de significar o próprio Manual na sua relação com "novos métodos”. Nessa carta apresentada aos professores, o autor afirma: "Han sido aprovechadas las sugestiones de los más modernos y seguros preceptos didácticos” (ibid.). Além disso, observa-se que "la gramática ha sido reducida a los puntos esenciales”. Aparece novamente o sentido mais prático dado ao livro que também está relacionado ao modo de apresentar e trabalhar as questões gramaticais. Nesse sentido, as explicações são simplificadas e são retiradas as notas explicativas da versão anterior, que adentravam na história e no funcionamento da língua. O tópico gramatical é trabalhado em meio aos outros componentes da lição, ajustando-se melhor ao Programa 
da disciplina que, a diferença do Programa do Colégio Pedro II de 1919, não estava estruturado apenas sobre questões gramaticais.

O autor anuncia a parte antológica como “menos densa”, embora, como ele mesmo diz, consiga "reunir las más altas glorias de la literatura hispánica” e continuar “con su aspecto ecléctico, en la esperanza de ofrecer materia provechosa a todos los buenos gustos literarios y a todas las sanas orientaciones” (ibid.). Na carta, como se pode notar, abordam-se as mudanças (na língua, no sentido prático do livro, na simplificação gramatical, numa antologia menos densa) que dão ao livro uma cara nova e, como efeito, a possibilidade de estar mais adequado às diretrizes do Estado. Transcorridos vários anos da entrada do espanhol no currículo, o livro não só deveria disputar sua circulação com um mercado editorial expandido, mas também teria passado por dois anos de uso e por uma real necessidade de adequação: sem deixar de considerar as exigências do Programa, atender a realidade do ensino da língua na escola, com pouquíssimo tempo semanal de aula.

Se nesta versão já não estão as palavras do autor e de Giusti que de forma específica se referiam à história da língua, à identificação dos países com o destino da América, o texto de Rodó, América, pareceria apresentar essas questões de outra forma, remetendo a uma "patria grande e única”, a uma "patria americana”. A necessidade de estudar a língua para uma “maior e mais íntima vinculação espiritual com as nações irmãs do continente”, manifestada na Exposição de Motivos da Reforma Capanema e a "fraternidade latinoamericana” expressada pelo autor na versão anterior, se fazem presentes de outro modo, num texto literário que se apresenta como uma espécie de manifesto.

Cabe observar que nesta segunda versão, os paratextos entram numa certa oscilação. Começam sendo a carta aos professores e o texto América, mas em um determinado momento a carta é omitida, permanecendo apenas o segundo.

Já na última versão, desaparecem as palavras do autor presentes nas anteriores de diferentes modos e passam a coexistir (lado a lado) duas materialidades específicas com as quais o leitor se depara ao abrir o livro: uma carta do Diretor da Real Academia Espanhola (RAE), Ramón Menéndez Pidal, com data de 1948, dirigida ao professor Idel Becker; e o próprio texto América do escritor uruguaio José Enrique Rodó. 

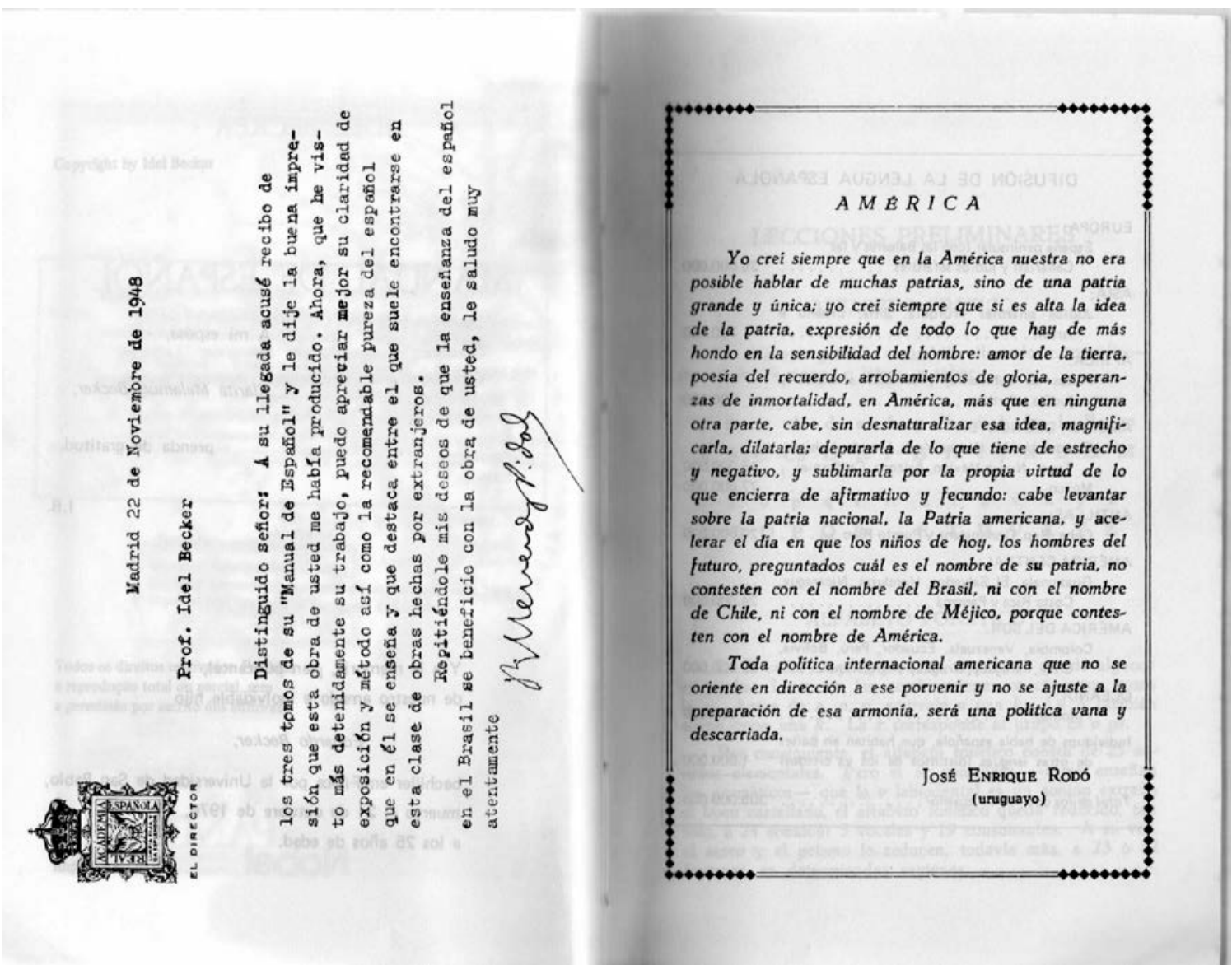

Essas duas textualidades nos despertam uma pergunta inicial: que imaginários projetam? Não se trata apenas de buscar sentidos que ajudem a compreender a autoria que coloca essas materialidades específicas (aparentemente tão distantes) em relação, mas também, de compreender aspectos da vida e das ideias de dois intelectuais de peso no campo linguístico, político e cultural, seja atuando na área de filologia, seja na literatura, no jornalismo, na política e na educação. Quem foram Ramón Menéndez Pidal e José Enrique Rodó? Mais do que aprofundar nas biografias dos dois autores, os apresentamos e tentamos compreender aspectos de suas posições com relação à língua.

\subsection{Menéndez Pidal e a carta encaminhada a Idel Becker}

Os aspectos da trajetória intelectual de Pidal nos interessam para entendermos a importância que o filólogo espanhol teve na construção de uma narrativa sobre a língua, sobre a história (política) da língua e, fundamentalmente, sobre a sua unidade. Menéndez Pidal (1869-1968) foi filólogo, historiador, medievalista espanhol e pioneiro da linguística moderna na Espanha, sendo, como afirma Del Valle (1997) o primeiro a 
elaborar uma Gramática histórica da língua espanhola segundo os cânones dominantes na Europa. Ingressou na RAE em 1902 e foi seu diretor a partir de 1926, cargo que ocupava nos anos em que o Manual foi produzido. Segundo esse mesmo estudioso, Pidal foi uma figura importante na criação de uma versão sobre a história política do espanhol, defendendo em diferentes épocas da sua carreira a concepção unitária da língua e manifestando importantes e diversas reações diante de uma suposta fragmentação (Del Valle, 1999). Del Valle (2015) também afirma que o Manual Elemental de gramática histórica de la lengua española, de 1904, foi uma das publicações que fez de Pidal um dos pesquisadores espanhóis mais destacados em matéria de linguagem e filologia. Trata-se, por tanto, de uma figura significativa na construção política da língua espanhola, isto é, na construção de uma narrativa elaborada em um momento histórico concreto e ressuscitada em outros, ao serviço de projetos ligados a interesses nacionais espanhóis (ibid., p. XV) ${ }^{195}$.

A carta presente no Manual nos permite pensar uma série de questões. Uma mais geral se refere à incorporação da missiva depois de tantos anos de ter sido escrita. A carta é de 1948, no entanto, é incorporada ao Manual nas edições que ocorreram após 1961. Qual seria a sua função passados tantos anos? Num mercado concorrido e disputado, seria uma forma de validar o livro - nacional e internacionalmente - por meio de uma voz de autoridade? O espanhol, assim como as outras línguas estrangeiras, já não estava no currículo, o mercado tinha mudado e os destinatários, certamente, também.

A leitura da carta também nos permite compreender que foi escrita em resposta ao envio de três tomos do Manual:

Distinguido señor: A su llegada acusé recibo de los tres tomos de su "Manual de Español” y le dije la buena impresión que esta obra de usted me había producido" (Becker, 1988, p. 10).

Quando Pidal encaminha a missiva, Becker já tinha escrito as duas primeiras versões do Manual - bastante diferentes entre si -, não podendo saber sobre qual delas o filólogo espanhol produziu sua "boa impressão", embora nos inclinemos a pensar que o procedimento de Becker, por uma prática de época, tenha sido enviar a de 1945.

A continuação, Pidal comenta:

Ahora, que he visto más detenidamente su trabajo, puedo apreciar mejor su claridad de exposición y método así como la recomendable pureza del español que en él se enseña y que destaca entre el que suele encontrarse en esta clase de obras hechas por extranjeros (ibid.).

195 Para aprofundar nesses aspectos, ver Del Valle (1997, 1999, 2015). 
As palavras acima dão destaque à “claridad de exposición y método”, assim como à “recomendable pureza del español”. Diante disso, caberia perguntar: quais seriam os sentidos projetados pelo sintagma la recomendable pureza del español quando Pidal se refere à língua ensinada no Manual? Só uma análise do interior do livro, onde estariam concentrados os sentidos de pureza que levaram Pidal a fazer essa afirmação, pode lançar luz sobre essa pergunta.

Por fim, também nos interessa chamar a atenção para o final do fragmento anterior onde se afirma (em tom elogioso) que a pureza do espanhol ensinado "destaca entre el que suele encontrarse en esta clase de obras hechas por extranjeros". A afirmativa do filólogo nos desperta uma série de questões. Por um lado, a obra - por meio do espanhol ensinado - parece “destacar” dentro de uma classe, a das “obras hechas por extranjeros”, cujas produções pareceriam não ter, no geral, tão boas impressões do filólogo. O sintagma que define a classe nos leva a perguntar: a obra de Becker não destacaria se comparada com produções feitas por "nativos" da língua? Ou seria outro o sentido de estrangeiro que estaria ai implícito? Becker seria estrangeiro com relação a uma nação (à Espanha?)? Ou seria estrangeiro com relação à língua (que pelas afirmações de Giusti, podemos pensar que não era). Pidal, certamente, desconhecia a biografia de Becker e, dessa forma, desconhecia o fato do autor estar atravessado pela língua espanhola que, segundo Giusti, era também sua língua materna.

Parece estar implícita aí a divisão projetada muitos anos depois por Auroux ([1992] 2009, p. 120) ao se referir aos conceitos de endo e exo-gramatização que, justamente, distinguiriam lugares dos sujeitos produtores dos instrumentos linguísticos segundo eles sejam ou não locutores nativos da língua gramatizada ${ }^{196}$. Dentre os aspectos envolvidos nessa distinção, o autor se refere ao saber epilinguístico, de cunho não consciente ou inconsciente que todo falante tem como relação “à sua língua” (ibid. p. 16 e 76) e que não se faria presente no caso da exo-gramatização. A carta de Pidal, que inclui o trabalho de Becker na classe de "obras hechas por extranjeros", nos permite aproveitar a reflexão acerca do par conceitual elaborado por Auroux. Assim, no contexto da nossa pesquisa caberia indagar: o que seria endo e exo-gramatização no Brasil, um território no qual o espanhol não é língua nacional, mas no qual essa língua foi introduzida no ensino secundário (nos anos 1920 e na Era Vargas) por razões que a

${ }^{196}$ Diniz (2010, p. 55-56) retoma ambos os conceitos para refletir sobre o início da gramatização do português como língua estrangeira no Brasil. 
definem como "singularmente" estrangeira, pelo fato de ser vizinha e próxima? Seria exo-gramatização, segundo os conceitos de Auroux, a produção feita no Brasil desde começo do século XX por autores brasileiros por não serem estes nativos da língua? Deveríamos identificar como endo-gramatização as produções espanholas que, embora elaboradas por autores nativos dessa língua, vieram "transportadas” de outro espaço geopolítico de produção para o qual foram pensadas? Que indicaria “exo” (de fora) ao refletirmos sobre a língua espanhola gramatizada no Brasil?

A partir do par conceitual elaborado por Auroux e aproveitando o que ele nos suscita, abrimos uma reflexão para pensar as particularidades dessa gramatização específica da língua espanhola feita por autores brasileiros, em território brasileiro. Uma gramatização - que segundo o par conceitual se trataria de exo-gramatização - marcada por relações fortes de comparação com a língua do brasileiro. O que nos parece interessante destacar é que assim como diversos autores já se referiram às particularidades no processo de aprendizado do espanhol por brasileiros, também seria o caso de compreender (como o fizeram Nascentes e Becker, apesar das determinações instauradas pela longa existência de um centro normativo) as particularidades que implicaria, então, esse processo de gramatização específico e reconhecer que a “memória local” - à qual faz referência Orlandi (1993) - e as "realidades particulares” às quais se referem Bourdieu e Wacquant (2002) - são cruciais nesse processo de elaboração de instrumentos linguísticos.

A carta presente no Manual, também nos permite abrir um espaço para outras reflexões. Por um lado, nos leva a indagar tanto sobre a relação de Becker com a RAE que o parabeniza pela produção da obra, como sobre o acompanhamento que essa instituição e seu diretor (Menéndez Pidal em aqueles anos) fazem do ensino do espanhol no Brasil. Pouco podemos dizer sobre a primeira indagação, a não ser que o envio pelos próprios autores dos materiais elaborados a instituições e estudiosos reconhecidos como uma forma de fazer circular as ideias e as produções - era uma prática comum à época, executada de forma intensiva já por Nascentes décadas antes ${ }^{197}$. No entanto, sobre a segunda indagação, podemos afirmar que a RAE esteve sempre atenta ao ensino

\footnotetext{
${ }^{197}$ Fazemos essa afirmação após termos tido um primeiro contato com as cartas internacionais passivas as recebidas por Nascentes de diferentes lugares do mundo -, nas quais o agradecimento pelo envio de obras diversas (a Tese de concurso, o Ensaio de Fonética, O Idioma Nacional, o Linguajar Carioca, o Dicionário Etimológico, o Método Prático de Análise Lógica, os Estudos Filológicos) e parabenizar o autor pela obra recebida são temáticas que ocupam uma porcentagem significativa dentro do conjunto geral das cartas. Vale recordar que a Gramática de Nascentes (1920) também apresenta uma carta da mesma instituição (RAE), agradecendo o envio de um exemplar da que fora a Tese do concurso (1919), apresentada no Colégio Pedro II.
} 
de espanhol fora das fronteiras da Espanha, preocupação que incluía o ensino dessa língua como estrangeira nos dois países não hispânicos mais importantes do continente americano: Brasil e Estados Unidos ${ }^{198}$.

A missiva de Pidal no livro de Becker, além de nos remeter àquela enviada pela instituição a Nascentes, em 1920, nos remete, especialmente, à carta que o filólogo espanhol enviara em 1917 à recém instituída American Association of Teachers of Spanish nos Estados Unidos e que, em fevereiro de 1918, sairia publicada no primeiro número da revista dessa associação, Hispania ${ }^{199}$. Isso nos leva a estabelecer relações interdiscursivas entre elas. Duas cartas vinculadas ao ensino da língua, enviadas desde Espanha, um centro político que tinha clara a "necessidade" de manutenção da unidade e pureza da língua. As relações interdiscursivas mostram, por um lado, um intelectual atento ao ensino de espanhol como língua estrangeira nesses dois “gigantes” não hispânicos da América (o Brasil e os Estados Unidos ${ }^{200}$ ), nos quais a língua ia incrementando sua presença, e por outro, um intelectual especialmente preocupado com o modelo da língua que ia ser ensinada. Que rastros encontramos da imagem de língua que o filólogo espanhol projeta na longa carta encaminha à Associação dos Estados Unidos e na carta presente no livro de Idel Becker e que relações podem ser estabelecidas?

Dentre outros fines, na carta enviada à American Association of Teachers of Spanish, Pidal queria "saludar con cariño la útil idea de la publicación de la revista” (1918, p.1), já que, sendo os Estados Unidos o país onde mais aumentava o ensino da língua "no puede ser indiferente que para el mejor cultivo de esa enseñanza inicien los profesores norteamericanos un importante acto de esmero y consagración” (ibid.). Del Valle (1999) analisa a carta e assinala que o filólogo espanhol "se proponía aconsejar a los miembros de la naciente asociación sobre el modelo concreto a seguir”.

Nesse mesmo trabalho, afirma que a maior parte da carta está dedicada a argumentar em favor de duas teses que insistem no caráter unitário e estável da língua: uma delas sustenta que tanto na fala popular como, em maior medida, na língua culta, tinha se logrado um alto grau de coincidência entre a Espanha e a América Latina; a segunda tese defende que a futura fragmentação da língua espanhola era improvável.

\footnotetext{
198 Aqui vale a pena registrar, com base em Celada (2019), que um século depois do envio da carta, o Brasil e os Estados Unidos continuam sendo os dois grandes objetivos da política pan-hispânica, levada adiante - dentre outros - pelo Instituto Cervantes, braço cultural do Estado espanhol.

199 Agradeço a Daniela Lauría pelo envio da carta aqui analisada.

200 Segundo Sánchez (1992, p. 289), no inicio do século XX, das 203 universidades existentes nos Estados Unidos, 124 incluíam o espanhol na grade curricular. Os livros publicados também eram numerosos.
} 
Del Valle também analisa a re-elaboração dos sentidos presentes na carta num texto alinhado a outro gênero e produzido por Pidal em 1944, La unidad del idioma (um discurso pronunciado com motivos da inauguração da Asamblea del Libro Español), mostrando como quase trinta anos depois o filólogo espanhol retomara as hipóteses formuladas no texto encaminhado à American Association of Teachers of Spanish. No entanto, assinala que o que no primeiro texto se apresentava como uma tese que tentava provar a unidade do espanhol, em 1944 era abandonada como tal para funcionar como premissa: a unidade do espanhol era apresentada como posta, como uma evidência. No caso, a argumentação do filólogo se centra na segunda das teses, a que aborda a improbabilidade da fragmentação da língua. Del Valle (1999) destaca que em diferentes textos e fundamentalmente em La lengua española: una carta de Don Ramón Menéndez Pidal (1918) e em La Unidad del idioma (1944), Pidal busca convencer seus leitores da unidade indissolúvel da língua espanhola, construindo discursivamente essa narrativa sobre a unidade da língua.

Da carta enviada à Associação de professores dos Estados Unidos nos interessa destacar esses dois argumentos: o da unidade e o da não fragmentação da língua, que são questões que atravessam o imaginário de época (nas próprias disputas ao interior das políticas linguísticas nos países hispano-falantes) e que, como veremos, deixam marcas no Manual.

Del Valle (ibid.) também argumenta que na carta de 1917, o filólogo espanhol não só insiste no caráter unitário e estável da língua, desenvolvendo uma tese destinada a provar tal unidade, mas ainda, argumenta a favor da adoção nos Estados Unidos de um tipo de norma, de uma variedade, de um modelo de espanhol para estrangeiros que deveria se centrar na língua culta e literária e na variedade castelhana.

Ao abordarmos certas questões normativas nas diferentes versões do Manual, apresentaremos as tensões e vaivens - como efeito de contradições constitutivas e históricas - entre, de um lado, o reconhecimento que Becker faz da história e da força que ainda carregava a RAE e os instrumentos linguísticos produzidos por essa instituição e, de outro, a diversidade da língua, apresentada na distribuição geográfica do funcionamento linguístico ${ }^{201}$. As marcas detectadas assinalam que o Manual não se alinha de forma rígida aos sentidos que, em diversos trabalhos, o filólogo espanhol

201 Tomamos o conceito de "contradição” de Pêcheux (1977). Para o autor essa não é de cunho lógico, mas histórico. Na sua base há uma relação de desigualdade: ao longo dos processos históricos (instaurados a partir da conquista e colonização) tal desigualdade se materializa na divisão entre uma norma central e tudo aquilo que, na língua, não faz parte dessa norma. 
deixa transparecer com relação à pureza del español e a um modelo linguístico que, partindo da heterogeneidade, gera unidade linguística e cultural (Del Valle, 1997). Pidal é claro e assertivo com relação ao normativo, Becker, com parte de seus estudos realizados na Argentina e com um ideal de "fraternidade latino-americana" deixa marcas, como analisaremos adiante, dessas antigas (e continuas) tensões.

\subsection{Rodó e o texto América}

José Enrique Rodó (1871-1917) nasceu em Montevidéu, Uruguai, e morreu em Palermo, Itália. Foi ensaísta, crítico literário e narrador. Além de escritor de renome, foi político, deputado (eleito em 1902, 1908 e 1911), periodista e professor universitário (Asencio, 2004). Segundo Benedetti (2001), esse autor tinha sido uma das vozes que se ouviram na América Latina para revelar a possibilidade de opor aos Estados Unidos todo um grupo de nações unidas pela herança, o idioma e o passado comum. Diz Benedetti:

la suya fue una de las primeras voces que se alzaron en América Latina para reivindicar la común raíz latina de estos pueblos, y revelar asimismo la posibilidad de oponer a Estados Unidos todo un haz de naciones, unidas por la herencia, el idioma y el pasado comunes (ibid., p. 204).

Para Rodó, o feixe de nações ("haz de naciones”) que deveria fazer frente à política intervencionista dos Estados Unidos incluía a Espanha como origem dessa raiz comum, fato que, se por um lado apresenta o sentimento anti-norteamericano que a intervenção dos Estados Unidos a Cuba, em 1898, despertara no intelectual uruguaio, também mostra a valorização de uma tradição espanhola e uma veta hispânica que o aproximava às ideias do filólogo espanhol. Para Rodó, tinha havido apenas uma revolução hispano-americana, cujo destino histórico

\footnotetext{
no fue alumbrar un conjunto inorgánico de naciones, que pudieran permanecer separadas por estrechos conceptos de la nacionalidad y de la patria, sino traer a la faz de la tierra una perenne armonía de pueblos vinculados por la comunidad del origen, de la tradición, del idioma, de las costumbres, de las instituciones; por la contigüidad geográfica, y por todo cuanto pueda servir de fundamento a la unidad de una conciencia colectiva (Rodó, 1913, p. 155).
}

Assim, no plano político, para Rodó “a revolução” deveria produzir uma harmonia para além das fronteiras nacionais, afirmação que antecipa a designação que no texto América se referirá à “Patria grande”, à “Patria americana”. Uma "Patria grande” que deveria ter uma língua comum. Desse modo, no plano sociocultural, Rodó aderia à tradição européia (Asencio, 2004), reivindicando o sentimento de fidelidade ao passado 
e à "fuerza directriz y plasmante con que debe el genio de la raza imponerse en la refundición de los elementos que constituirán al americano definitivo del futuro" (Rodó 1910, p. 83 apud Asencio 2004, p. 228). A língua, nesse sentido, passa a ser considerada como um dos mais importantes bens herdados que a educação deveria preservar: Rodó opta pela norma “espanhola” (ibid., p. 230-231). Era o espanhol da Espanha, diz Asencio, o que deveria ser escolhido como modo de apropriação da essência da raça superior que está nas origens. A autora conclui afirmando que "a hispanofilia de Rodó se manifiesta con especial énfasis con respecto a lo lingüístico” (ibid., p. 230), promovendo na educação e na prensa a legitimação da variedade peninsular. Com base em Del Valle e Stheeman (2002) ${ }^{202}$ a autora explica essa filiação ao hispanismo - o movimento que intentou criar um clima de harmonia para preservar a imagem de uma “autêntica civilização hispânica” com centro em Espanha e propagada por América - e que se articula em torno a várias ideias:

la existencia de una cultura, un estilo de vida, características, tradiciones y valores puramente españoles, todos ellos incorporados en la lengua, la idea de que la cultura hispanoamericana no es otra cosa que la cultura española trasplantada al Nuevo Mundo, y la noción de que la cultura hispánica tiene una jerarquía interna en la que España ocupa una posición hegemónica (Asencio, 2004, p. 220).

Assim, não é de surpreender que Rodó tenha sido designado correspondente estrangeiro da Academia Espanhola ${ }^{203}$, em 1912, como lemos no verbete sobre o autor, presente no “Nuevo Dicionário de Literatura Uruguaya L-Z”, escrito por Benedetti (2001, p. 204).

Ao refletir sobre o texto de Rodó no Manual de Idel Becker, duas leituras diferentes (e aparentemente contraditórias) parecem interessantes. Uma, a mais simples e direta, a que nós mesmos fizemos num primeiro momento, a que faria - imaginamos -

202 Del Valle. José e Luis Gabriel Stheernan. Nationalism. Hispanismo. and Monoglossic Culture". The Battle over Spanish between 1800 and 2000: Language Ideologies and Hispanic Intelíectuals ed. por J. del Valle e L.G. Stheernan. 1-13. London and New York: Routledge, 2002.

${ }^{203}$ Segundo consta no site da RAE:

La categoría de académico correspondiente, formalizada en los estatutos de 1859, distingue a personas reconocidas por sus investigaciones, estudios y publicaciones sobre distintas materias relacionadas con la lengua o la literatura españolas. Contribuyen a los fines de la institución desempeñando las tareas que esta les encomienda e informando de las variantes del español en sus lugares de residencia.

Disponível em: http://www.rae.es/la-institucion/los-academicos/academicos-correspondientes; acesso em: 13/5/2017. Parece importante observar que houve, em momentos diferentes, diversos rechaços a esse diploma acadêmico outorgado pela RAE. Uma das polêmicas mais importantes foi a protagonizada pelo argentino Juan María Gutiérrez, após rechaçar o título oferecido em 1875. O rechaço buscava desconhecer o lugar hierárquico da RAE e o purismo linguístico que a instituição prescrevia e reconhecer a heterogeneidade linguística. Nesse sentido, Ennis e Pfänder (2013, p. 38) assinalam que um dos argumentos mais fortes de Gutiérrez para repelir o cargo foi "la pertenencia a una pujante ciudad moderna, que no tolera os oscurantismos que todo casticismo vendría a imponer”, fundando aí sua resistência à presença da RAE "en la proyección de una Buenos Aires moderna, liberal y cosmopolita". 
a maioria dos leitores e a que fizeram alguns pesquisadores, trabalha apenas sobre a materialidade do texto América ${ }^{204}$. A outra levará em consideração as filiações do autor às origens hispânicas e a valorização das raízes ibéricas como elemento importante constitutivo da identidade latino-americana (Gouveia, 2012).

Dessa forma, para refletir sobre o texto América, seguindo a primeira leitura proposta, nos concentramos nos sentidos de integração americana que estão aí colocados, remetendo a uma "patria grande e única”, a uma “patria americana”, sentidos próximos aos expressados na Exposição de Motivos da Reforma na qual se fazia referência à importância do estudo do espanhol para uma "maior e mais íntima vinculação espiritual com as nações irmãs do continente”, e próximos também à “fraternidade latino-americana” expressada pelo autor do Manual no Prefácio da primeira versão. E também indagamos as antecipações sobre o interior da obra que a leitura inicial desse texto produz, afetando as perspectivas do sujeito leitor.

Assim expressa Rodó suas ideias nos dois parágrafos que compõem o texto:

Yo creí siempre que en la América nuestra no era posible hablar de muchas patrias, sino de una patria grande y única; yo creí siempre que si es alta la idea de la patria, expresión de todo lo que hay de más hondo en la sensibilidad del hombre: amor de la tierra, poesía del recuerdo, arrobamientos de gloria, esperanzas de inmortalidad, en América, más que en ninguna otra parte, cabe, sin desnaturalizar esa idea, magnificarla, dilatarla; depurarla de lo que tiene de estrecho y negativo, y sublimarla por la propia virtud de lo que encierra de afirmativo y fecundo: cabe levantar sobre la patria nacional, la Patria americana, y acelerar el día en que los niños de hoy, los hombres del futuro, preguntados cuál es el nombre de su patria, no contesten con el nombre de Brasil, ni con el nombre de Chile, ni con el nombre de Méjico, porque contesten con el nombre de América.

Toda política internacional americana que no se oriente en dirección a ese porvenir y no se ajuste a la preparación de esa armonía, será una política vana y descarriada (itálico nosso).

Uma primeira observação nos permite refletir sobre o sintagma “América nuestra”, uma América de tradição ibérica que possuía uma constituição distinta da América anglo-saxão. Duas Américas com tradições muito distintas sobre as quais Rodó se debruçou nos seus escritos. De forma mais ampla, como pode se observar, no texto se valoriza a dimensão política do continente. Mais do que uma pátria nacional, uma pátria americana que atravesse as fronteiras nacionais. A “política internacional” devia se orientar a esse propósito, projetando o reconhecimento futuro por parte das

\footnotetext{
${ }^{204}$ Lembremos que a materialidade do texto América foi recortada de uma obra mais ampla à qual não se tem acesso direto.
} 
crianças de aqueles anos, dessa Pátria Grande, dessa pátria americana que incluía o Brasil. A dimensão política se faz presente na composição desse breve texto.

Numa primeira leitura, a carta de Menéndez Pidal e o texto de Rodó colocados lado a lado no começo do livro nessa terceira versão -, se apresentavam como duas materialidades marcadas por posições diferentes: a pureza da língua clamada na primeira e a Pátria Grande na segunda, o que nos levou a pensar se haveria ai um conflito regional, territorial, linguístico ou político.

Tentando aprofundar essa primeira interpretação, nos perguntamos: que outra leitura poderia ser feita da relação desses dois textos (a carta de Pidal e o texto de Rodó) colocados em duas páginas lado a lado, tentando compreender as questões linguísticas apresentadas na carta de Pidal a partir da leitura desse texto, América, um recorte de um texto mais amplo que se apresenta - no interior da obra de Becker - como uma espécie de manifesto? Existe uma tensão que tem a ver com conflitos de época, uma tensão, por um lado, entre o que era o ideal político independentista das nações que buscavam, ao mesmo tempo, a consolidação das independências políticas e a criação de uma pátria grande, e, por outro, o valor dessa Pátria ter uma língua comum (a unidade da língua tão amplamente defendida). É interessante notar que no texto de Rodó não se fala da língua (a língua era uma), isso dava valor e era o elemento constitutivo dessa grande nação.

A unidade da língua já tinha sido uma preocupação em Bello (Lara, 1996; Arnoux, 1999, 2008; Fanjul, 2011) e continuava se alinhando aos imaginários de época, em tensão, certamente, com outros. Vale lembrar as disputas de Sarmiento com o próprio Bello sobre os caminhos que deveria seguir a língua em território americano (Fanjul, 2011) e as disputas que na Argentina, na época do centenário da revolução (1910) também tiveram um lugar de destaque ${ }^{205}$. Também vale lembrar que essas disputas não tinham se plasmado, ainda, nos instrumentos linguísticos que impunham a norma. A unidade da língua e uma norma central e purista continuavam ocupando a linha de frente e tomando conta das disputas, quando a questão era a produção de instrumentos linguísticos.

Mas essa língua comum da Pátria Grande, impulsionada por grande parte dos intelectuais hispano-americanos, continuava deixando à Espanha num lugar de destaque nas relações de força dos aspectos normativos: como afirmava Becker, tinham sido 250 anos de formulações e de ações prescritivas assentadas nos instrumentos linguísticos produzidos por

205 Sobre este tema, ver Glozman e Lauria (2012). As autoras recopilam e analisam a importância que tiveram os debates sobre a identidade linguística na Argentina. 
essa instituição. Essas tensões se repetem no interior do livro, como apresentaremos nos próximos itens, e se repetem ao longo da historia do espanhol no Brasil.

Entendemos que na coexistência da carta de Pidal e do texto de Rodó, pareceria se manifestar essa tensão/contradição histórica existente na época entre a projeção de sentidos que, ao mesmo tempo em que convocam uma "uma patria americana”, “uma pátria grande”, projetam uma matriz linguístico-cultural (entendida como regularidade) que valoriza uma tradição espanhola e a "pureza” de uma língua comum, aspectos que, entendemos, atravessam a materialidade do Manual ${ }^{206}$. Pidal e Rodó estavam alinhados no ideário hispanista, no entanto desses dois textos parecem surgir as contradições inerentes a discursos que se pronunciam pela independência política e, ao mesmo tempo, pela unidade (e continuidade) linguístico-cultural.

Como colocamos acima, outra questão importante dos paratextos é pensar quais outros imaginários essas materialidades convocam. Retomando formulações de Alvarado (2009), vale lembrar que os paratextos representam o lugar onde podem ser formuladas as primeiras hipóteses a propósito do texto que será lido, portanto, onde a interpretação pode começar a funcionar perante um sentido que é sempre aberto, opaco e por vezes contraditório. Diversos pesquisadores se referiram aos possíveis sentidos que o texto de Rodó projeta sobre o continente, estando presente em um livro para o ensino da língua. Dois deles interpretaram essa projeção na direção de uma heterogeneidade das variedades abordadas e dos mundos representados. Vieira (2012) assinala que os dizeres desse texto projetam sentidos que filiam a língua espanhola aos países hispano-falantes da América e não apenas ou de um modo exclusivo à Espanha. Na mesma direção, Giglio (2006, p. 58) apontara que "a escolha [desse] texto para a abertura do livro é um indicativo que demonstra o sentimento do autor a respeito da questão da inclusão do espanhol da América com suas variantes”. No entanto, como viemos afirmando no texto, a independência política das jovens nações hispano-americanas não estava em relação direta com a independência linguística e nem cultural, segundo Asencio.

Apresentar a diversidade da língua era uma preocupação para Becker, abordada em diversos momentos na elaboração da obra. Entre tanto, quando o foco está posto nas leituras que iniciam cada uma das lições, muda ao longo das reformulações a realização

\footnotetext{
${ }^{206}$ Aqui vale a pena pensar que as independências das jovens repúblicas hispano-americanas já estavam consolidadas. Os inimigos e os temores eram, por um lado, os Estados Unidos - e nesse sentido é muito pertinente o poema A Roosvelt (1904), do escritor nicaraguense Rubén Darío, uma clara denuncia contra o imperialismo e as intromissões dos Estados Unidos no continente - e, por outro, os efeitos dos fluxos migratórios e os perigos que eles representavam para a coesão nacional em cada uma das nações. Nesse ponto, a tão perseguida unidade da língua teria sua força política.
} 
dessas antecipações iniciais. As projeções realizadas (especialmente ao observarmos a última versão, posterior a 1961) entram em confronto com o modo como Espanha e Hispano-américa são projetadas na materialidade das leituras que compõem a obra. Também nesse aspecto o trabalho de reformulação vai produzindo transformações, afetando o recorte de leituras e as relações que podem ser estabelecidas entre essas e os paratextos. Analisaremos esse aspecto no item 5.

\section{As tensões históricas: entre uma norma central e a diversidade linguística}

Este ponto concentra uma questão importante do nosso trabalho, não só no esforço de tentarmos entender as tensões históricas dos discursos sobre a língua espanhola e os efeitos no processo de gramatização dessa língua no Brasil, mas, especialmente, porque é um dos pontos que integra o emaranhado inicial de indagações que nos levaram à realização da pesquisa. Vale retomar: se a partir dos anos 1990 o mercado editorial é preenchido com certa naturalidade por livros espanhóis que tinham um olhar determinado sobre o ensino da língua e da cultura (alinhado a uma centralidade da Espanha) e que marcaram por mais de uma década a produção de outros instrumentos linguísticos e o próprio ensino, como tinha sido essa presença peninsular do ponto de vista cultural, linguístico e por tanto, político com relação à língua espanhola no Brasil? ${ }^{207}$ Em termos de Foucault, poderíamos perguntar sobre a sua genealogia, não buscando uma origem, mas buscando presenças anteriores.

Na primeira versão (1945), a seção Gramática Espanhola constitui a primeira parte do Manual de espanhol e já de saída apresenta o que entendemos é uma constante e um "ponto de articulação”"208 entre o Manual e a Gramática de Nascentes: a tensão como efeito da contradição histórica -, entre uma norma central e o reconhecimento da diversidade da língua e de uma distribuição geográfica do seu funcionamento. É claro que o modo em que essa tensão se manifesta nesses dois momentos históricos e nessas duas obras atravessadas por condições de produção diferentes e por histórias de vidas específicas é também diferente.

\footnotetext{
${ }^{207}$ Também vale lembrar que chega ao Brasil - foco de expansão internacional do Estado espanhol -, em 1998, o Instituto Cervantes, como estratégia para a promoção internacional da língua.

${ }^{208}$ Tomamos essa formulação de Celada (2002), que a utiliza ao analisar o Manual de Idel Becker e, especificamente, ao se referir ao trabalho de colocar as línguas em contraste, dando continuidade ao já realizado por Nascentes na Gramática de 1920. Nesse sentido, deveríamos nos referir a ele como um "outro (ou novo)" ponto de articulação.
} 
A pergunta orientadora é: como acontecem essas tensões ao longo das três versões do Manual? Para abordarmos os deslocamentos que vão sendo produzidos na reescrita da obra, tomamos a discussão que se faz sobre duas modalidades fonéticas (o seseo e o yeísmo) e sobre um aspecto morfossintático (o voseo). É importante salientar a representatividade desses três traços da língua no espaço rioplatense (no qual Becker tinha vivido); uma variedade não dominante, mas de presença expressiva no mundo do espanhol. Entendemos que esses aspectos encarnam, em certa forma, a tensão Espanha-América ${ }^{209}$.

Assim começa o Capítulo 1 - Fonologia, da versão de 1945 - no qual são abordados os dois primeiros - e cujo subtítulo é Principais Modalidades Fonéticas:

\begin{abstract}
As primeiras dificuldades fonéticas não residem, como poderia parecer, na pronúncia dos sons estranhos à língua portuguesa (ch, j, z), mas na adopção dum tipo único de fonética. Poderíamos restringir-nos, sem maiores considerações, ao esquema ideal, teórico, do dialeto castelhano - que nós chamamos DIALETO ACADÊMICO - simbolizado na gramática e no dicionário da Academia Espanhola. A imparcialidade, porém, o espírito crítico, a honestidade científica, mandam dizer que essa seria uma solução muito simplista, e muito cômoda, mas nem sempre de acordo com a realidade, com a opinião dos professores e com a conveniência dos alunos (Becker, 1945, p. 15).
\end{abstract}

O Manual começa com a apresentação de uma tensão e com o autor assumindo uma posição ao reconhecer a dificuldade que implicaria ter que se restringir a um único dialeto, o castelhano, ou como ele mesmo afirma: "Dialeto Acadêmico” (Becker, 1945, p. 15). Em contraposição, aborda-se a diversidade das realizações fonéticas da língua. A partir de uma tomada de posição do autor, na qual se afirma que embora “poderiam” ter se restringido a um modelo teórico ideal que estaria representado no dialeto castelhano $^{210}$, “a imparcialidade”, “o espírito crítico” e “a honestidade científica” mostram que seria "uma solução muito simplista e muito cômoda". O autor apresenta uma língua dividida entre o dialeto castelhano e o que não faz parte dele, uma condição de desigualdade à qual se opõe, já que "nem sempre [está de acordo] com a realidade, com a opinião dos professores e com a conveniência dos alunos”. O próprio autor estava atravessado por outro “dialeto” (o rioplatense), então, como não apareceria de alguma forma esse reconhecimento? Mas também, como apresenta o recorte, estava atravessado pela sua experiência docente.

\footnotetext{
${ }^{209}$ Tomamos Espanha-América como um binômio construído a partir da primeira, um centro político que o instaurou.

${ }^{210}$ Vale lembrar aqui que esse tinha sido o dialeto sugerido por Pidal na carta enviada à Associação de professores de espanhol dos Estados Unidos, publicada em 1918 e já analisada no item 2 deste capítulo.
} 
É interessante a nomeação de “dialeto castelhano” e “dialeto acadêmico” para o que a partir da RAE é colocado como norma central. Na obra diferenciavam-se os falares diferentes:

\begin{abstract}
Não falam igual um mandrileno (sic) e um habitante do interior de Castela ou um andaluz; nem um castelhano, em geral, e um hispano-americano; nem um mexicano e um portenho de Buenos Aires. Nas diversas regiões espanholas e hispano-americanas o problema não existe, uma vez que se adota - em todos os estudos - a pronúncia local. No Brasil a solução é delicada e ela requer, de todos os modos, o conhecimento dessas diferenças (ibid.).
\end{abstract}

Para o autor, esses modos diversos de falar não eram um problema nas diferentes regiões espanholas e hispano-americanas, já que, como se afirma no próprio texto, em cada uma de elas se adotava nos estudos a pronúncia local. No Brasil, no entanto, a solução era “delicada” e requeria “o conhecimento dessas diferenças”. As tensões estavam instaladas e as soluções delicadas vão oscilar entre o respeito que o autor tem pelos 250 anos de ação da Academia e as suas próprias convicções e conhecimentos sobre a diversidade, marcados pela sua experiência como falante dessa língua. Um vaivém que apresentaremos ao longo das análises.

E falamos em tensões porque, ao mesmo tempo em que no Manual se adere a certas questões formuladas a partir de uma norma central, aparecem marcas da sensibilidade do autor - enquanto sujeito da linguagem - para a diversidade da língua e para certos usos censurados pela Academia. Uma amostra disso surge na apresentação do seseo:

\title{
“SESEO” $(\mathrm{Z}=\mathrm{S})$
}

$\mathrm{O}$ z (e o c, antes de e, i) tem - no dialeto acadêmico - um som especial línguo-dental, análogo ao th inglês (forte), como em - three. Em muitas regiões da Espanha, porém e em toda a América soam como o s espanhol (lingual-dental, sibilante, forte). É o que se chama seseo, que a Academia acioma ainda de "vício", mas que deve ser considerado, apenas, uma "modalidade fonética" que, aliás, vem-se impondo nítidamente por tôda parte (Becker, 1945, p. 15 e 16).

Interpretamos que há aí contrapostos dois modos de significar o funcionamento linguístico, e a tomada de distância com relação aos dizeres da Academia - inclusive por meio de marcas de "heterogeneidade mostrada” (Authier-Revuz, 1990) naquilo que a instituição chama de "vício", e que para Becker funcionava apenas como uma “modalidade fonética” - assinala a percepção do autor com relação à diversidade do funcionamento da língua. Essa tensão também se manifesta na nota explicativa sobre o tema (omitida nas versões posteriores), que Becker cita de Giusti (lembremos: argentino, integrante da Academia Argentina de Letras e professor de Becker no ensino médio), embora em nenhum momento registre a obra fonte: 
Dice Giusti: la z y la c dulce (ce, ci) son interdentales, esto es, se pronuncian adelantando la punta de la lengua contra los bordes de los incisivos superiores, sin cerrar por completo la salida del aire, pero en América y en algunas regiones de España, es un hecho general el seseo, que consiste en pronunciar ambas letras como s (apud Becker, ibid., p. 16).

Após as palavras de Giusti, Becker destaca, em caixa alta, a afirmação final do seu Mestre, materializando a tomada de posição na própria escrita: "NINGÚN GRAMÁTICO AUTORIZADO REPROCHA YA EL 'SESEO' COMO UN VICIO, POR SER COMÚN A TODAS LAS CLASES SOCIALES, AÚN LAS MÁS CULTAS”. E finaliza a exposição justificando a adoção da forma americana

Ya se comprende que es la forma americana $(\mathrm{z}=\mathrm{s})$ la que adoptamos en nuestras clases. Imponer la z castellana a nuestros alumnos sería someterlos a un terrible esfuerzo del cual están libres millones de españoles e hispanoamericanos. Se perderían semanas enteras en ayudarlos a superar tal dificultad. ¿'Y para qué? (Becker, 1945, p. 16).

As explicações sobre o seseo trazem à tona a experiência de Becker como professor, uma experiência que utiliza para justificar as opções realizadas. Ao mesmo tempo, apresentam uma crítica às posições hierárquicas da Academia, relativizando a norma ditada a partir de um centro normatizador.

A segunda das modalidades fonéticas que tomamos do Manual, o “yeísmo (ll=y)”, também tem uma abordagem ampla, mostrando as diferentes pronuncias e comparando-as com sons do português. O autor vai apresentando os diversos modos de pronúncia da letra $l l$, mostrando como seria o sonido equivalente em português, por meio da apresentação de grafias:

O ll corresponde, no dialeto acadêmico, ao diagrama português "lh" (linguopalatal molhado), como em ‘TRABALHO', 'FOLHA'”(ibid., p 16).

A continuação apresenta a diversidade:

Os madrilenos, alguns meridionais da Espanha e os americanos em geral fazem o ll igual ao y (yeísmo), isto é, dão-lhe um som linguopalatal semioclusivo, como o do “i” português em ‘praia', 'iodo', 'maio’” (ibid.).

Observemos em primeiro lugar, a generalização com relação ao yeísmo em América: “os americanos em geral”, respondendo, pensamos, a um imaginário como efeito da falta de estudos específicos sobre o tema e da existência da oposição Espanha-América para abordar o funcionamento linguístico. Também vale observar que embora nas explicações - marcadas pelas formações imaginárias que respondem a uma prática pedagógica - não sejam mobilizados os símbolos fonéticos, o autor apresenta aos alunos 
as respectivas designações conceituais: "linguopalatal semioclusivo" e "linguopalatal fricativo” na apresentação de mais uma pronuncia:

alguns núcleos de argentinos, uruguaios e paraguaios - que pronunciam o y como "j" português - dão ao ll esse som linguopalatal fricativo, como em 'haja', 'objeto', 'rijo'” (ibid.).

Finalmente, por meio de um exemplo, encerra a explicação e apresenta as diferentes formas de pronunciar a palavra caballo: "por um castelhano - cabalho; por um mexicano - cabaio; por um portenho - cabajo”.

A nota explicativa correspondente ao yeísmo, também citando Giusti, traz uma descrição ampla e heterogênea dessa modalidade fonética, poucas vezes vista em um livro dedicado a alunos brasileiros do ensino médio ${ }^{211}$, na qual, por exemplo, são apresentadas as diferenças de caráter regional dessa modalidade, possíveis de serem encontradas na Argentina:

En la Argentina, por ejemplo - según declara Santiago Lugones en el prólogo a su edición del Martín Fierro - hay tres elles distintas: la elle castellana (Corrientes, San Juan y La Rioja), que suena como una I seguida de i: caballo suena como cabal-io, la elle fuerte o áspera (Buenos Aires y Santiago del Estero): caballo suena como cabayo; y la elle de la provincia de Córdoba, y también de Catamarca y parte de Tucumán, que suena como una i: caballo suena como cabaio (Giusti, apud Becker, ibid., p. 16, negrita do autor).

Essa explicação, além de apresentar a diversidade, quebra inclusive o imaginário de uma "pronúncia nacional” (única), ou de um funcionamento da língua que seria o mesmo em todo o território de uma nação. Pensamos especialmente nas explicações dadas nos livros de espanhol para brasileiros, em diversos momentos do seu processo de gramatização - especialmente nas últimas décadas apesar da quantidade de estudos desenvolvidos sobre o tema - não só sobre o yeísmo na Argentina, mas, de forma mais geral, sobre o funcionamento da língua em um território nacional. Esses modos de apresentar e explicar produzem simplificações, achatamentos, reduções dentro de um processo de generalização que apaga a diversidade.

Se com relação ao seseo Becker afirma que adota nas aulas a forma americana (para não expor os alunos às dificuldades da pronúncia do “dialeto acadêmico”), no caso do yeísmo optará pelo "Il mexicano”: "En nuestros cursos hemos adoptado, en general, la elle mejicana, que nos parece la más extendida y es, quizás, la más conveniente para

\footnotetext{
${ }^{211}$ Fazemos essa afirmação com base na leitura atenta de um amplo leque de livros produzidos até a primeira década do século XXI. Parte desse trabalho de análise foi desenvolvido ao longo da pesquisa de mestrado (Sokolowicz, 2014).
} 
un brasileño” (ibid., p. 17). Ao mesmo tempo deixa claro que serão praticados "os três ll”, em diferentes situações:

en la lectura de poesías pronunciamos la ll al modo castellano, costumbre harto frecuente aún en países americanos, nuestros alumnos suelen imitarnos sin mayor esfuerzo. Y, finalmente, en uno que otro pasaje, de trozos típicamente argentinos, permitimos que se ejerciten en la pronunciación de la elle bonaerense (ibid.) $)^{212}$.

Após essa explicação, o autor resalta que "entre centenares de discípulos brasileños” não recordava nenhum “que haya tenido mayores dificultades para aprender y practicar las tres elles”. Assim, afirma, "les hemos enseñado a conocer y respetar las tres modalidades fonéticas, cada una de ellas correcta en sus respectivas regiones”213 (ibid., p. 17). Essas explicações, ao mesmo tempo em que adentram no conhecimento da língua estrangeira, colocam o aluno em contato com uma forma mais ampla de funcionamento linguístico, fato que, em certas situações, permitiria expandir esse conhecimento e vivência para a língua própria, facilitando a percepção das diferenças e do diferente, e a possibilidade de respeitar, como se afirma no texto, cada uma delas. Observamos um gesto glotopolítico no modo de trabalhar a relação do aprendiz com as línguas e com a linguagem de modo geral. O autor expressa essa possibilidade de expansão e de transposição da observação sobre as línguas ao retomar essas questões no capítulo XVIII Vícios de Linguagem. Após se distanciar da Academia com relação ao seseo e ao yeísmo, afirma:

Lembremos que Portugal e o Brasil - e as diversas regiões portuguesas e brasileiras, entre si - têm também as suas divergências prosódicas. E nem por isso se dirá que estão ERRADAS tais ou quais modalidades fonéticas (ibid., p. 130).

Apesar das escolhas feitas, o autor esclarece que "cada profesor puede - y debe - adoptar, en su curso, el sistema que le parezca más conveniente o exacto, de acuerdo con su orientación y sus puntos de vista” (ibid.). A aclaração reforça a projeção de professores autônomos.

A tomada de posição do autor diante dos modos contrapostos de significar o funcionamento linguístico nas duas modalidades fonéticas abordadas até aqui (seseo e yeísmo) se repete nesse mesmo capítulo (Vícios de Linguagem) - um dos últimos da seção Gramática Espanhola -, quando são abordados os barbarismos ortográficos e prosódicos. Retomando de forma explícita o que já tinha sido exposto, no texto se expressa:

\footnotetext{
${ }^{212}$ É interessante observar no sintagma "harto frecuente" uma identificação desse sujeito da linguagem com formas regulares do espanhol no espaço americano.

${ }^{213}$ Como observamos anteriormente, o autor recupera uma experiência docente com um nós inclusivo.
} 
Já se viu que o seseo e o yeismo são, na severa opinião da Academia, vícios prosódicos. Para nós, repetimos, não passam de modalidades fonéticas, pertencentes a diversas regiões da Espanha e dos países hispano-americanos (ibid., p. 129-130).

O autor reforçava a distância tomada com relação à "severa opinião da Academia”, e ampliava o reconhecimento da diversidade com relação à Gramática de Nascentes que, vale lembrar, designava o seseo como "grave defeito” e "barbarismo", ao igual que o faziam as Gramáticas usadas na argentina no começo do século XX para o ensino da língua na escola que também qualificavam o seseo como "grave e imperdonable falta” (Blanco, 1999, p. 89).

Nesse mesmo capítulo, ao se referir ao yeismo, o autor volta a se distanciar da “excessiva intolerância” da Academia:

Parecer-nos-ia excessiva intolerância censurar o mexicano que pronuncia “cabaio" - a palavra caballo - ou o portenho que diz “cabajo”. Da mesma forma não aconselharíamos condenar taxativamente a pronúncia bonaerense “jerba” para a palavra yerba (Becker, 1945, p. 130).

No começo deste item falamos em tensões porque ao mesmo tempo em que a diversidade da língua se faz presente de forma clara, inclusive apresentando aspectos do funcionamento diverso dentro de um mesmo país, a adesão a uma norma representada como “central” também atravessa a produção do Manual.

Nesse sentido é claro o modo em que é abordado o aspecto morfossintático conhecido como voseo, presente no Capítulo VII ao tratar dos Pronomes Pessoais. Pareceria até um paradoxo (que na verdade é efeito da contradição referida anteriormente) já que se trata de um uso “arraigado”, como o próprio Becker reconhece, na cidade de Buenos Aires, onde o autor tinha passado parte de sua vida e feito o ensino médio. Vale à pena transcrever a explicação na íntegra:

Em certas regiões da América emprega-se com maior ou menor freqüência, a palavra vos, em lugar do pronome tú. Essa expressão, errada e vulgar, constrói-se com formas verbais incorretas, em que há, quase sempre, síncope do i: vos sos (de sois), vos tenés (de tenéis), vos andás (de andáis).

Este censurável vício de linguagem - denominado voseo - acha-se arraigado na conversa familiar, sobretudo nas cidades de Buenos Aires, Montevidéu, e em outros centros menores como Rosário, Asunción, etc. Já anos atrás Bello reprovava-o: "El vos de que se hace tanto uso en Chile en el diálogo familiar, es una vulgaridad que debe evitarse”. Mais tarde verificava Juan V. Selva: "He podido comprobar personalmente que en Chile la gente más culta pone buen cuidado en evitar el voseo, que viene quedando relegado al uso de la gente ignorante, lo que me hace creer que este perfeccionamiento del habla es obra de la escuela, de los educadores.

E hoje, diz Giusti: "Pero hay otro vos muy generalizado en el lenguaje familiar de nuestro país (Argentina) que convendría desterrar de la conversación y que es suma incorrección emplear cuando se escribe”... “El voseo argentino y de algunas otras partes de América, que sorprende tanto a 
los españoles y demás americanos, es una forma viciosa y vulgar, que la escuela debe en lo posible procurar corregir”214 (Becker, 1945, p. 65).

Observemos que a nota apresenta um uso estendido do voseo: "em certas regiões da América emprega-se com maior ou menor freqüência a palavra vos”, “acha-se arraigado na conversa familiar, sobretudo nas cidades de Buenos Aires, Montevidéu, e em outros centros menores como Rosário, Asunción, etc.”, “el vos de que se hace tanto uso en Chile en el diálogo familiar (citando a Bello)”, e em palavras de Giusti, volta-se sobre Argentina: "pero hay otro vos muy generalizado en el lenguaje familiar de nuestro país”. No entanto, essa apresentação vai acompanhada de um caráter normativoprescritivo do texto escolar: “essa expressão errada e vulgar”, "este censurável vício de linguagem”, “una vulgaridad que debe evitarse”, um uso “que convendría desterrar de la conversación y que es suma incorrección emplear cuando se escribe”, "una forma viciosa y vulgar, que la escuela debe en lo posible procurar corregir”. Na última das anomalias mencionadas, na citação de Giusti, vem à tona a oposição (tão clássica) oralidade/escrita. Vejamos que o gramático reconhecia o uso num outro "vos generalizado en el lenguaje familiar”, mas a escola deveria "procurar corrigir" e essa correção se daria, certamente, na escrita.

Reflexões de Bello, Selva e Giusti dão sustento às afirmações do autor sobre a vulgaridade do voseo, fato que nos faz indagar: por que o reconhecimento do seseo e do yeísmo e a reprovação do voseo? Uma pergunta que se por um lado nos parece chave para compreendermos como são colocadas as questões prescritivas e a relação norma/diversidade, também tende uma ponte com a Gramática de Nascentes e os aspectos já abordados no capítulo 2.

Uma aparente contradição - poderíamos pensar após analisar o modo como é abordado o voseo - que, no entanto, está estreitamente vinculada à história da língua espanhola desde a conquista de América e aos debates e disputas que aconteceram no continente americano após a independência política das jovens Repúblicas na primeira metade do século XIX (com exceção de Cuba). Essas tensões estavam instaladas no interior da própria história das políticas linguísticas no mundo hispânico, especialmente na Argentina, lugar de formação escolar do Becker e onde, segundo López García (2009) tais políticas oscilavam entre um “purismo hispânico” e a “valoração das

\footnotetext{
${ }^{214}$ Embora na obra de Becker não exista nenhuma referência às fontes citadas, detectamos que a citação de Giusti sobre o voseo foi extraída textualmente (com alguns cortes) da seguinte obra do autor argentino: "Gramática y ejercicios de idioma. Primer Curso", Buenos Aires: Angel Estrada Editores S.A., da qual consultamos a 24 edição, 1956, p. 15.
} 
variedades regionais”. A autora (2009, p. 57) analisa o papel da escola e dos manuais escolares na conformação de um sujeito da língua que se constitui numa duplicidade: língua espanhola/língua argentina. E é justamente esse confronto o que produz, ao longo da história, as tensões que vemos reproduzidas no Manual.

A Real Academia Espanhola (RAE), ligada desde suas origens (1714) ao Estado espanhol, foi a primeira instituição que regulou sobre a língua. Como afirma López García, se trata de "una institución al servicio de un determinado proyecto de EstadoNación que debía garantizar y velar por la unidad de la lengua castellana”. A estudiosa explica que foi justamente a variedade castelhana (que Becker denomina "dialeto acadêmico”) a que iria servir de base para a construção de uma língua standard, necessária para o projeto político de unificar a nação no final do século XIX. A seleção dessa variedade regional, diz a autora, responde mais a motivações extralinguísticas (predominantemente político-econômicas) que a questões puramente linguísticas.

As diferenças fonéticas, léxicas e sintáticas do espanhol nos vastos territórios que a língua ocupa foram tratadas e aceitas de diferentes modos. Se as variedades fonéticas (como o seseo e o yeísmo) tiveram uma aceitação mais tranquila ao longo do tempo, as morfossintáticas (dentre elas o voseo) foram vistas como modalidades que atentavam para a manutenção da unidade da língua. Na análise que Asencio (2009) faz da Gramática de Bello, especialmente do Prólogo da obra, fica claro o que acabamos de expressar. O autor afirma que para Bello o perigo não estava nos neologismos léxicos, mas nas “innovaciones sintácticas que alteran `la estructura del idioma”” (ibid., p. 9). Asencio assim justifica:

Esos neologismos de construcción, que violentan lo que para Bello sería el genio natural de la lengua, podrían abrir brecha para la ruptura de la deseable unidad lingüística y, por ello, deben ser proscritos. De hecho, el gramático adopta tono reprobatorio para llamar la atención sobre algunos de ellos (ibid.).

Observemos que as reprovações sintáticas não provinham apenas da Academia, mas estavam instaladas também nessa Gramática de la lengua castellana destinada al uso de los americanos, de Bello (1847). Essas tensões entre o que eram inovações possíveis e o que era perigoso para a manutenção da unidade linguística têm a ver com a historia das políticas linguísticas do espanhol ao longo dos séculos, e deixam suas marcas no Manual de Becker - e de modo geral na produção de instrumentos linguísticos ao longo do século XX -, um autor que viveu a contradição histórica que atravessa o funcionamento da língua no próprio território argentino e na escola desse país, em seus anos de formação. 
Vale lembrar aqui os constantes debates e disputas que existiram, desde finais do século XIX e ao longo de significativas décadas do século XX, ao redor do lugar da língua nos processos de unidade regional e da autonomia linguístico-institucional que as nações independentes da América colocavam com relação à Espanha (Glozman, Lauria, 2012). Pensando que a Academia Argentina de Letras reconheceu o voseo só em 1982 (López García, 2009), ainda caberia indagar: poderia o autor do Manual ter percorrido outro caminho no processo de produção da obra e no trabalho mais específico com esse aspecto morfossintático e com outros aspectos da língua?

Se as independências das Repúblicas americanas da Espanha tiveram como efeito, dentre muitos outros, os debates e disputas que acabamos de mencionar, é importante retrocedermos até a conquista da América para entendermos o que Lara (1996, p. 345) designa como um “hecho simbólico” e que se torna fundamental, não só para compreendermos o desenvolvimento da lexicografia hispano-americana e espanhola (o campo de estudo do pesquisador), mas também para compreendermos as contradições, tensões, debates e disputas que se instalaram de modo mais geral no território da língua. Assim é explicado pelo linguista mexicano:

La conquista de América no solamente produjo el fenómeno objetivo de la expansión del español por una gran parte del nuevo continente, tal como lo intuyó Nebrija, sino que estableció un hecho simbólico cuya vigencia permanece en nuestra concepción social de la lengua española: creó un sujeto histórico y una localización geográfica de nuestra lengua de acuerdo con los cuales España, la metrópoli, y su corte o sus autores literarios determinan la "verdadera imagen de la lengua española" -según expresión reciente de un lexicógrafo español-, mientras que Hispanoamérica se convirtió en permanente periferia de la lengua y objeto pasivo de los juicios de corrección peninsulares: reiteradamente sospechosa de barbarismo, aunque muchas veces perdonada indulgentemente por lo pintoresco de sus amerindianismos, sólo se la puede mirar como arcaica, como andalucista, como objeto de una siempre posible redención (Lara, 1996, p. 345).

A continuação, o autor afirma que a lexicografia hispanoamericana e espanhola "se ha desarrollado sobre la base de ese hecho simbólico, reforzado por otros fenómenos ideológicos” dentre os quais:

el valor supremo de la conservación de la unidad de la lengua, establecido a partir de Nebrija pero fortalecido por Andrés Bello y Rufino Cuervo, como ejemplos sobresalientes; y la autoridad prescriptiva de la Academia Española” (ibid.).

Lara afirma que para poder compreender a produção de diccionarios (“desde el de la Academia hasta el más humilde de los americanos” [ibid. p. 346]) e explicar seu desenvolvimento, é importante partir desses símbolos ideológicos. O estudioso 
apresenta claramente a relação que divide a língua espanhola e que está na base da contradição histórica que produz as tensões e vaivens abordados no livro de Becker.

Se as explicações de López Garcia trazidas acima permitem compreender as tensões numa temporalidade e num espaço mais restritos, após as independências do século XIX, as colocações de Lara retomam e expandem temporalmente o modo como se expressam as tensões que viemos apresentando no capítulo e que, claramente, atravessam a memória do espanhol no Brasil e o processo de gramatização para seu ensino.

Voltando às análises das modalidades fonéticas e morfossintáticas e ao modo como são abordadas na primeira versão do Manual, a modo de síntese podemos reafirmar que se no seseo e no yeísmo, as explicações aproximaram o pêndulo das prosódias regionais, reconhecendo-as, no voseo o pêndulo ficou do lado do censurável, do vício, de uma norma ditada a partir de um centro, negando a possibilidade de um funcionamento diverso da língua ${ }^{215}$. Desse lado fica também o Capítulo XVIII - Vícios de Linguagem. Segundo o autor,

os vícios de linguagem destruem a pureza, propriedade e elegância do idioma. A Academia Espanhola aponta entre os principais vícios de dicção os seguintes: barbarismos, solecismos, cacofonia, anfibología ou obscuridad, monotonia y pobreza" (Becker, 1945, p. 128).

Uma nota do próprio autor deixa clara a origem desse capítulo, as determinações do Programa expedido pelo Ministério de Educação e Saúde em 1943 e a aprovação que o autor faz delas:

El programa de español, aprobado por resolución ministerial del 2 de febrero de 1943, incluye en su desarrollo el estudio de los vicios de dicción. Esta exigencia, que podría parecer audaz e imprudente, porque destinada a alumnos "extranjeros" -es, sin duda alguna, necesaria y provechosa. La divergencia que existe, en portugués, entre el habla culta, correcta, gramatical, y el idioma vulgar, descuidado- se repite en castellano, como en cualquier otra lengua viva.

Prevenir al alumno brasileño contra tales errores -algunos de ellos, infelizmente, harto extendidos- es tarea práctica, eficaz y oportuna. No sea que al encontrarse más tarde con esos vicios de dicción -en la conversación, en los diarios y revistas, y aun en buenos libros de lengua castellana- se imagine el alumno brasileño, que le han enseñado mal las reglas del idioma, o que no supo aprenderlas debidamente, atribuyéndose una culpa que no le cabe. Y que, entonces, por natural escrúpulo, tema enmendar lo que haya sido mal dicho o mal escrito en español. El hecho de que alguno hable o escriba

\footnotetext{
${ }^{215}$ Neste ponto, podemos compreender o fato de que Becker, quem foi aluno da escola argentina e estudou com manuais e livros que abordavam o "voseo" como forma incorreta, não tenha podido se colocar de outro modo diante desse gesto de exclusão. Para o ouvido dos puristas, o fenômeno implicava um expressivo desvio da linha que pensa a língua etimologicamente e não consegue aceitar uma forma que vem do plural e se instala no singular. Nesse sentido, vale a pena dizer que esse fenômeno hoje está ausente das formas de dizer do território espanhol, onde sim se conserva, no plural, a oposição "vosotros/ustedes".
} 
fluentemente su lengua materna no le concede privilegios gramaticales, ni lo exime de equivocarse y poder ser corregido por un "extranjero". Que en todas partes cuecen habas (ibid.).

O autor explica a importância da inclusão dos “vicios de dicción” no Programa oficial da disciplina e a possibilidade de um “extranjero” reconhecer os “errores” (e poder corrigilos) de alguém que fale ou escriba fluentemente essa língua como materna. A projeção dessa possibilidade por parte de Becker nos permite inferir a antecipação que o autor fazia dos seus alunos (e dele próprio) e do aprendizado da língua. Mas por que as aspas para “extranjero”? Não deixa de ressoar aqui o termo utilizado por Menéndez Pidal poucos anos depois para especificar, dentro da produção gramatical do espanhol, o lugar dado à obra de Becker que, lembremos, “destaca” dentre as elaboradas por “extranjeros”.

Até aqui apresentamos como são abordadas essas modalidades na primeira versão do Manual e, a partir de Lara e López García, propusemos uma reflexão que ajuda a compreender a forma que a língua foi tomando ao longo do seu processo de gramatização no Brasil. Para continuarmos horizontalmente a análise das outras duas versões do Manual de Becker, cabe perguntar: como se manifestam essas modalidades em cada uma delas? Que transformações ocorrem no trabalho de reformulação da obra?

Como afirmamos anteriormente, de modo geral, vai havendo reduções nas explicações que implicam em omissões (das notas), recortes e síntese, e em certa atenuação dos aspectos mais conflituosos.

Observemos em primeiro lugar como se realiza nessas duas versões a introdução do item Principais Modalidades Fonéticas. Na de 1947, a introdução do item se reduz a dois curtos parágrafos. Uma redução que parece entendível quando refletimos sobre a estrutura desse gênero específico (manual) e quando compreendemos que os aspectos gramaticais iam acompanhados de uma variedade de práticas: leituras, exercícios, provérbios, expressão oral.

Nessa segunda versão, não existia o espaço que houve na primeira para reflexões e explicações mais aprofundadas que incluíam, inclusive, as experiências de Becker como docente. Na versão de 1947 e na final (após 1961) não são apresentadas as “dificuldades” pelas quais passaria um professor brasileiro na eleição do tipo de fonética - aspecto que estava diretamente relacionada com a experiência docente do autor e com o fato da língua estar sendo ensinada fora de um país hispânico e sobre o qual o autor se deteve nas edições de 1945. Na síntese e simplificação o foco está colocado em ressaltar 
o mais essencial das explicações da primeira versão: a não unidade léxica e fonética. Isso seria o mais importante, tal como se expressa no Manual:

Así como no existe rigurosa unidad léxica en todas las regiones de habla española, tampoco existe absoluta identidad fonética en toda España y en los países de Hispano-América. Ya se comprende que no hablan exactamente igual un madrileño y un andaluz o un catalán; ni un castellano y un hispanoamericano; ni un mejicano y un porteño.

Las principales divergencias fonéticas se reducen a tres cuestiones esenciales: el seseo, el yeísmo y la pronunciación de la v (Becker, 1947, p. 23).

Embora tenham sido omitidos aspectos das controvérsias e das experiências do autor que ampliavam a compreensão dessas questões, o mais importante é mantido: a não unidade nem léxica nem fonética,

Já na versão final esses dois parágrafos se mantêm e, intercalado entre eles, é incorporado um terceiro que traz a voz da autoridade - neste caso nas palavras de Menéndez Pidal - para reafirmar ou confirmar o que acabava de ser afirmado sobre os diferentes falares:

La pronunciación española no es la vulgar del pueblo de Castilla, ni la del vulgo de ninguna otra región. Los castellanos no pronuncian todos de igual modo; los andaluces tampoco; los hispanoamericanos se diferencian bastante entre sí. ¿Quién podría imponer la norma? Ninguno de un modo absolutamente general (Menéndez Pidal, apud Becker, 1986, p. 24) ${ }^{216}$.

A versão final, de modo geral, apresenta esse movimento como constante: na necessidade de redução e síntese já não se apresenta - como na de 1945 - a disputa e a tomada de posição do autor se distanciando dos dizeres da Academia, mas a voz de “autoridades” que apresentam as diferenças como modalidades e não mais como “vícios”, no dizer da Academia. No entanto, observe-se como nesse recorte específico, nas palavras de Menéndez Pidal, essa diversidade está vinculada a determinadas valorações, especialmente no primeiro enunciado que inclui duas operações de negação significativas: "la pronunciación española no es la vulgar del pueblo de Castillo, ni la del vulgo de ninguna otra región”.

Vejamos como acontece isso no seseo, um caso claro desse movimento que elimina as disputas. Assim se enuncia na versão de 1947:

La z y la c (en las combinaciones ce, ci) tienen, en la pronunciación académica un sonido linguodental, análogo al de la th inglesa (fuerte) como en three. Pero en algunas regiones de España y en toda América suenan como la $s$ castellana (silbante). Esto es lo que se llama el seseo (Becker, 1947, p. 23).

\footnotetext{
${ }^{216}$ Infelizmente o livro de Becker não traz a bibliografia, dessa forma é difícil saber de onde foi extraído esse recorte de Menéndez Pidal.
} 
Para finalizar a explicação é trazido o enunciado final da nota explicativa de Giusti da versão de 1945: “Ningún gramático autorizado reprocha ya el seseo como un vicio, por ser común a todas las clases sociales, aún las más cultas” (Giusti, apud Becker, ibid.). Na versão final - que transcrevemos na íntegra -, vemos transformações, por um lado, nas designações da produção dos sonidos (de linguadental se passa a interdental e de silbante a alveolar) e, por outro, nas autoridades que validam a explicação do autor, já não é Giusti (como em 1945 e 1947), mas Menéndez Pidal e Navarro Tomás:

\footnotetext{
La $z$ y la $c$ dulce (ce, ci) tienen -en la pronunciación académica- un sonido interdental, análogo al de la th inglesa (fuerte) como en three. Pero en algunas regiones de España y en toda la América hispánica se pronuncian como la s castellana (alveolar). A esta modalidad fonética se denomina seseo. "El seseo de andaluces y americanos se halla admitido en la pronunciación culta” (Menéndez Pidal).

"La opinión general castellana acepta este seseo como modalidad dialectal que los andaluces, extremeños, canarios e hispanoamericanos pueden usar sin reparo en Castilla hasta en los círculos sociales más cultos y escogidos” (Navarro Tomás). (Becker, 1986, p. 24-25).
}

Esse movimento se repete na apresentação do yeísmo. Da versão de 1945, já não está a nota explicativa de Giusti sobre a diversidade do yeísmo em diferentes regiões da Argentina, nem a justificativa do tipo de $l l$ adotado nos cursos, nem a prática diversa com os diferentes sonidos. É mantida a descrição inicial da modalidade e a explicação dos diversos sons por meio da grafia do português. Embora sejam identificadas as diversidades “nacionais”, são apagadas com relação à primeira versão as diferenças regionais dentro de um mesmo país, um aspecto que desconstruía a ideia de "nacional” como unidade.

Como no seseo, novamente na versão final, num parágrafo que não estava em 1947 e que fecha as explicações, é citada uma autoridade:

En los países hispanoamericanos no se ha perdido completamente la ll. Se conserva en algunas zonas de la Argentina, Chile, Perú, Colombia y Ecuador. En los libros escolares de estos países se recomienda combatir el yeísmo y reponer el sonido de la $l l$ (Navarro Tomás) (Becker, 1986, p. 25).

Vamos observar agora o terceiro dos aspectos abordados, o voseo, buscando compreender as transformações que ocorrem. Vale lembrar que na primeira versão, o autor se posicionava junto aos dizeres da Academia e que as palavras de Bello, Selva e Giusti reforçavam a afirmação de ser o voseo uma "expressão errada e vulgar” e um “censurável vício de linguagem”. Na segunda versão se mantém a explicação inicial, se apresentam as formas e as cidades em que "el voseo se encuentra arraigado" e as que "han quedado indemnes" (Becker, 1947, p. 57). Também se afirma que na Espanha daqueles anos "el voseo [era] desconocido" (ibid.). Finalizando a explicação, são 
introduzidas as vozes de Amado Alonso e Henríquez Ureña. É interessante observar que nelas, os filólogos não se posicionam negativamente, apenas descrevem - ampliando de forma considerável - a "Distribución y diferencias del voseo en América” (título das palavras citadas no livro de Becker) da seguinte forma:

Vos reemplaza a tú, dentro del habla familiar, en una gran porción de América: la Argentina, el Uruguay, y, menos profusamente, el Paraguay, Chile, Bolivia, el Perú (en parte), el Ecuador, Colombia (a excepción de la costa norte), parte de Venezuela, parte de Panamá, Costa Rica, Nicaragua, El Salvador, Honduras, Guatemala, el estado mejicano de Chiapas y una pequeña parte de la zona oriental de Cuba. En cambio, emplean exclusivamente el tú Méjico y Cuba -con las dos pequeñas excepciones señaladas-, Santo Domingo y Puerto Rico, gran parte de Venezuela y de Panamá, el norte de Colombia y la zona del Perú cuyo centro es Lima.

El uso del vos no es uniforme en todas las regiones donde se conserva: así, por ejemplo, en la Argentina es común en todas las clases sociales, pero en Colombia está relegado al habla popular”217 (apud ibid.).

No trabalho de reformulação que produz a última versão é omitida a nota de Amado Alonso e Henríquez Ureña e, com ela, o uso estendido do voseo que era apresentado.

De modo geral, na transversalidade que nos permitiu abordar aspectos da composição das três versões, pode-se observar o seguinte movimento: na primeira versão há um posicionamento do autor e uma apresentação mais ampla de alguns aspectos da diversidade e das disputas sobre a língua, na segunda e na terceira há uma redução que na síntese põe o foco na não unidade fonológica da língua (no caso do seseo e do yeísmo).

Os próximos pontos do capítulo (4 a 7) giram ao redor dos elementos que compõem as lições que organizam o livro a partir da segunda versão. Assim, transitaremos entre a segunda e a terceira e faremos referência à primeira em algumas ocasiões que a análise a convoque. As análises que seguem põem o foco, assim, nos diversos aspectos que estruturam a obra como manual.

O Manual, na segunda versão e na final, apresenta uma primeira seção que contém as Lecciones Preliminares e uma série de trinta e dezoito lições respectivamente que organizam o estudo da língua. As lições começam com uma leitura, seguida de um provérbio, um tópico gramatical e, de modo geral, exercícios que abordam o tópico proposto. Cada uma dessas partes nos permite expandir a reflexão sobre a língua, o universo cultural representado e os sujeitos projetados (os destinatários).

\footnotetext{
217 Como mencionamos anteriormente, embora não existam referências sobre as fontes, a citação é um fragmento retirado textualmente da obra de Amado Alonso e Pedro Henríquez Ureña “Gramática Castellana - segundo curso”, Buenos Aires: Editorial Losada, da qual consultamos a 25a ed., de 1975, pp. 81-82.
} 


\section{As lições preliminares: o contraste entre as línguas}

Essa seção da segunda e terceira versão do Manual apresenta em poucas páginas alguns aspectos da língua distribuídos nos seguintes tópicos: alfabeto gráfico, alfabeto fónico, vocales, concurrencia de vocales, consonantes, signos de puntuación, silabeo, ejercicios de paronimia, ejercicio de análisis fonético, ejercicio de lectura y silabeo. Esses tópicos provêm, a partir de um trabalho de reformulação que implica em reduções do Capítulo 1 (Fonologia) da primeira versão de 1945.

As notas preliminares já permitem entrever o contraste entre as línguas, adotado como proposta de trabalho, uma questão também presente na primeira versão do Manual e nas outras produções do autor. A comparação e o contraste entre as línguas é uma constante nessa obra, observando especialmente as diferenças entre 0 funcionamento do espanhol e do português, mas sem deixar de assinalar as semelhanças, como se lê, por exemplo, na primeira página das Lecciones Preliminares, em que é apresentado o alfabeto fonético: “La h, como en portugués, no representa sonido alguno: es muda” (1947, p. 13).

Nessa seção, portanto, o espanhol vai sendo apresentado ao aluno mediante uma comparação que tem na base o português. Nesse sentido, ao apresentar as vogais, o autor vai fazendo referência ao sonido que corresponderia no português. Encontramos marcas disso em diversos exemplos: "La $a$ corresponde siempre a la $a$ abierta del portugués (á)” ou “la $u$ corresponde siempre a la $u$ aguda del portugués (ú)” (ibid., p. 14). Também ao se referir às consoantes, à separação em sílabas e aos signos de pontuação, o português vai organizando a comparação, seja nas aproximações ou nos afastamentos: "las siguientes consonantes suenan siempre como en portugués” (ibid., p. 15), “la $l l$, en la correcta pronunciación castellana suena como la "lh" mojada del portugués” (ibid., p. 17), “la ñ corresponde siempre a la letra doble `nh' del portugués” (p. 18), "la s suena siempre como 'ç’ o 'ss' portuguesas” (ibid., p. 18), “las únicas dificultades [de la división de las palabras en sílabas] para un alumno brasileño, residen en los casos de letras dobles (que son indivisibles)” (ibid., p. 20). Após a apresentação dos signos de pontuação, se afirma: "la única dificultad, para un alumno brasileño, está en el uso de los signos de interrogación y admiración. Ellos se ponen al principio y al final de la oración o frase que deba llevarlos (...)” (ibid.). Como vemos, a partir do contraste se reconhecem as semelhanças e se marcam as diferenças que criariam esses espaços de dificuldades onde a língua poderia produzir tensões para um aluno brasileiro. 
Podemos pensar que esse jogo de comparação entre as línguas que explora o contraste - embora referido ao espanhol de forma geral, sem especificações - remite, quando pensado em outro plano, à relação do Brasil com os países hispano-americanos que, se por um lado são semelhantes ao primeiro, também apresentam diferenças. Em alguns momentos, para reduzir a distância, tendeu-se a falar que as duas línguas (majoritárias) que estabeleceriam essa relação deviam ser compreendidas como uma língua só. E nesse sentido, assim o expressava Darcy Ribeiro $\left(1986^{218}\right.$, p. 84 apud Arnoux e Del Valle, 2010, p. 10, itálico dos autores)

Los españoles, portugueses e ingleses, que jamás consiguieron asimilar los bolsones lingüístico-dialectales de sus reducidos territorios, al trasladarse a la Américas impusieron a sus colonias, inmensamente mayores, una uniformidad lingüística casi absoluta y una homogeneidad cultural igualmente notable. Somos cuatrocientos millones de hablantes de dos variedades subdialectales (el portugués y el español) mutuamente inteligibles de una misma lengua. Cien kilómetros alrededor de Madrid o de Lisboa se encuentran mayores variaciones dialectales que en el castellano o lusitano del continente latinoamericano.

Celada (2002, p. 61) abordou o aspecto da comparação entre as línguas, reconhecendo no Manual de Idel Becker um “ponto de articulação” que daria acesso a dois planos. Um desses planos, diz a autora, remete a uma memória, inscrevendo-se numa linha que permitiria "afiliar o gesto de interpretação ao qual tal instrumento submete a língua espanhola à linha de reflexão [desenvolvida por] Nascentes”. Assim, o Manual daria continuidade a essa proposta em que o contraste não só está presente, mas constitui o escopo do trabalho. Em palavras de Celada (ibid. p. 73) “os estudos de Nascentes instauram e fundam uma interpretação acerca da língua espanhola que o Manual de Becker consolida e consagra”.

Tendo a comparação contrastiva como operação articuladora do trabalho, o Manual de Becker instaura o estudo do "vocabulário de divergências léxicas"219, dividindo-o em: heterotónicos (com e sem acento ortográfico), heterogenêricos e heterosemánticos. Um tópico que continua presente em grande parte das gramáticas e manuais escritos no Brasil para o estudo de espanhol por brasileiros.

Se a proposta de Becker consolida e consagra de diferentes modos o trabalho iniciado por Nascentes, especialmente nesse aspecto da comparação contrastiva entre as línguas, também é verdade que, a partir da segunda versão, amplia-se esse escopo de trabalho, por

${ }^{218}$ A obra referida de Darcy Ribeiro é America Latina, a Patria Grande. Rio de Janeiro: Editora Guanabara, 1986.

${ }^{219}$ Esse tópico já tinha aparecido na Gramática de Nascentes de forma sucinta e sem a divisão clássica que instaura Becker e que permanecerá até a atualidade. 
meio do universo cultural existente nas leituras que iniciam cada uma das lições, e também por meio dos provérbios e dos exercícios, aspectos que trataremos nos três próximos itens.

\section{As leituras iniciais das lições: Espanha e Hispano-américa}

Na segunda seção do capítulo anterior analisamos o item "Leitura” do Programa de Espanhol para os cursos clássico e científico. Como objetivo dessas leituras iniciais o documento estabelecia percorrer nos textos (em prosa e em verso) a paisagem e a vida nos países hispano-americanos e na Espanha. Junto com isso e numa instância mais ampla, na Exposição de Motivos da Reforma Capanema se destacava o caráter específico do ensino secundário: formar nos adolescentes uma "sólida cultura geral”, propiciando neles “formas de conhecer a vida”. Alguns aspectos das próximas análises nos permitirão iluminar o entrecruzamento dessas duas questões presentes no Programa e na Exposição de Motivos que interpretamos como cruciais na organização do livro.

Há uma reformulação significativa entre a versão de 1947 e a final, posterior a 1961. A primeira delas é composta por trinta lições e a última apenas por dezoito. Em ambos os casos, essas lições que integram a primeira parte do livro começam com uma "leitura inicial” que, se por um lado, é uma forma de responder aos requerimentos do Programa oficial, também implica num projeto pedagógico específico, diferente daqueles que trabalham tão só o aspecto gramatical. A prática de leitura exige do aluno uma posição mais ativa, na qual parece entrar em jogo o “eu” e “o outro”, o "próprio” e o "alheio" (como diferente) $)^{220}$. A organização em lições regulares e as leituras iniciais das mesmas marcam uma transformação significativa com relação à primeira versão ${ }^{221}$.

As primeiras dezoito lições se mantêm iguais nas duas versões: contêm as mesmas leituras, provérbios, abordagem gramatical e exercícios. Na versão final, só são omitidas as perguntas sobre cada leitura, presentes no item Conversación ${ }^{222}$.

\footnotetext{
${ }^{220}$ No capítulo 3 tínhamos anunciado que ao analisarmos o Manual de Becker faríamos alguns contrapontos com outro da época: Español Básico, de Calleja Alvarez. Nesse último, também organizado em lições, cada uma delas começa com um exercício de ditado. Em contraste com a prática de leitura proposta no Manual de Becker, os ditados sugeririam outro modo de se vincular ao texto, focalizando, numa reprodução mais passiva, a relação sons/ortografia.

${ }^{221}$ As leituras são selecionadas da Antologia da primeira versão do Manual.

$222 \mathrm{O}$ item Conversación da Lección 11, cuja leitura é Corrida de Toros propõe, por exemplo, as seguintes perguntas: "1. ¿Cuál es el espectáculo máximo del público español? 2. ¿A qué corresponderia, en Sudamérica, la corrida de toros? 3. ¿Qué se ve en la plaza de toros? 4. ¿Qué cubre el ruedo de la plaza? 5. ¿Cuántas son las suertes de la lidia y cómo se llaman? 6. ¿Qué otros nombres se da al torero que mata los toros con espada? 7. ¿Cuántos sinónimos de toro hay en la lectura? 8. ¿Cuáles son los sinónimos de
} 
O segundo bloco de lições, da dezenove à trinta, só está presente na versão de 1947. Todas elas apresentam um formato mais curto: incluem as perguntas sobre o texto, um provérbio e um questionário de literatura, não contendo, assim, nem o tópico gramatical e nem os exercícios sobre esse aspecto específico. Opera aí uma redução significativa e são justamente essas lições as omitidas na versão final. Uma interpretação, a mais direta e espontânea, poderia nos levar a dizer que o tempo real das aulas (bastante escasso) exigia um corte e que ele foi realizado de forma pragmática, separando esses dois blocos diferentes para que ficassem, na versão final, as lições que apresentavam um trabalho mais diversificado e que, além das leituras, abordavam os tópicos gramaticais e propunham exercícios. Porém, o que acaba chamando a atenção é que excluindo esse segundo bloco de lições e as respectivas leituras (de 19 a 30) ficam de fora as temáticas que giravam ao redor de assuntos, paisagens, lugares e história dos países hispanoamericanos. De fato, se na segunda versão existia um equilíbrio entre as leituras que abordavam fundamentalmente diversos aspectos e textos literários do espaço espanhol (presentes no primeiro bloco) ${ }^{223}$ e as que se ocupavam de temáticas e da literatura dos países hispano-americanos (no segundo) ${ }^{224}$, esse equilíbrio se quebra na versão final.

Em 1947, o espanhol estava instalado no currículo. Os argumentos para a incorporação da língua em 1942 tinham sido os de dar "um passo a mais para uma vinculação espiritual com os países do continente”. Por sua vez, o Programa exigia que os textos percorressem a vida e as literaturas da Espanha e dos países de Hispano-

multitud, empleados en esta lección?” 9. ¿Qué nombres se les dan a las suertes de capas? 10. ¿Qué otras expresiones como "gritos, aplausos, creciente exaltación”, describen la agitación y el entusiasmo del público? (Becker, 1947, p. 54). Como vemos, perguntas que apontam a questões diversas. Algumas perguntas solicitam do aluno uma informação específica do texto, outras uma interpretação semântica, especialmente para identificar sinônimos, outra (a 2), sai do texto e pede do aluno uma transposição cultural, a identificação do que poderia ser um espetáculo como esse em América do Sul. Perguntas variadas cujos formatos apresentam certas regularidades: algumas se vinculam ao texto, outras mais específicas versam sobre a língua e outras se concentram em estabelecer relações culturais ou tender pontes com o estudo da literatura.

223 1. Castellano, Español, 2. Don Quijote de la Mancha, 3. Calma (Antonio Machado), 4. España I, 5. España II, 6. España III, 7. Caperucita (Francisco Villaespesa), 8. La raiz del rosal (fragmento, Gabriela Mistral), 9. La flor del camino (Juan Ramón Jiménez), 10. Rima (Bécquer), 11. Corrida de Toros, 12. Niña que cose (Pio Baroja), 13 (sem leitura), 14. Rima (Bécquer)/Añoranzas (Valle Inclán), 15. Escalando la montaña (Teresa de la Parra)/ Una lucecita roja (Azorín), 16. Noche de primavera (ValleInclán), 17. La Paloma azul (Emilia Pardo Bazán), 18. La Paloma azul (continuación). Quando a leitura não traz o nome do autor, interpretamos que são textos do próprio Becker.

224 19. El descubrimiento de América, 20. Los indios de América (José Martí, cubano), 21. Visión de Hispanoamérica, 22. San Martín y Bolívar (B. Vicuña Makenna, chileno), 23. México (Carlos Castillo, mexicano), 24. La rosa blanca (José Martí), El sueño (Rafael Alberto Arrieta, argentino), Meciendo (Gabriela Mistral, chilena), Marzo (Juana de Ibarbourou, uruguaia), 25. El gaucho, 26. El rodeo (Adaptado de Ricardo Güiraldes, argentino e Rómulo Gallegos, venezuelano), 27. Las cataratas del Iguazú (José Vasconcelos, mexicano), 28. Nieve en los Andes, 29. Buenos Aires (Roberto F. Giusti, argentino), 30. Iberoamérica (Franco e Rodríguez, argentinos). 
américa o que permite inferir que, para além das convicções do autor, as condições de produção determinavam esse equilíbrio. Condições reforçadas pelo contexto político: quando Vargas volta à presidência da República pelo voto popular, em 1950, Perón era presidente da Argentina e, como já dissemos - com base em Ramos (1968) e Justo (1983) -, ambos os presidentes pensavam a existência de cada um dos países no contexto de América Latina.

Após 1961, as línguas estrangeiras são excluídas do currículo, caindo com essa exclusão as exigências do Programa e das diretrizes da Exposição de Motivos. Também muda a editora, passando da Companhia Editora Nacional à Editora Nobel, embora não possamos saber exatamente em que momento isso ocorre. Com a exclusão das línguas, muda também o número de alunos que potencialmente teriam aula com esse livro. Todos esses aspectos levam a pensar que a reformulação que implicou nesse significativo corte do segundo bloco (corte sempre político), respondeu a questões comerciais, à produção de um livro mais econômico em um momento em que a língua deixava de ter o destaque das duas décadas anteriores. Nesse corte reduzem-se por volta de 80 páginas e nessa redução Hispano-américa é omitida e, portanto, silenciada. Uma omissão que perdurará até a última reedição da obra, de acordo com nosso registro: 1996.

\subsection{O primeiro bloco de leituras: Espanha e a formação pedagógica e moral}

Uma primeira interpretação quantitativa das leituras que constituem o que chamamos de primeiro bloco permite pensar a projeção da Espanha e sua vida cultural, seja no universo de autores escolhidos, seja nas temáticas abordadas. Dos dezenove textos presentes ${ }^{225}$ dez são de autores espanhóis ${ }^{226}$; sete não têm referência autoral fato que nos leva a pensar que foram escritos pelo próprio Becker - embora seis deles abordem assuntos espanhóis (Don Quijote, España I, II e III, Corrida de Toros) e, o sétimo, uma temática histórica e polêmica sobre o nome da língua (Castellano, Español); restando tão só dois textos de autores hispano-americanos: um deles de Gabriela Mistral, escritora chilena ganhadora do premio Nobel de Literatura em 1945 e o outro de Teresa de la Parra, autora venezuelana. Uma pergunta parece significativa diante desse mapeamento inicial: por que foram duas mulheres as autoras hispano-americanas

\footnotetext{
${ }^{225}$ Duas lições apresentam dois textos e uma delas não tem nenhum.

${ }^{226}$ Antonio Machado, Francisco Villaespesa, Juan Ramón Jiménez, Bécquer (2), Pio Baroja, Valle Inclán (2), Azorín, Emilia Pardo Bazán.
} 
selecionadas? Uma hipótese seria pensar que nessa época as mulheres não estavam marcadas politicamente como sim estavam os homens que, além de escritores, muitas vezes tinham uma participação política em diversos âmbitos da vida da nação. Assim, a escolha dessas duas mulheres de renome das letras hispano-americanas poderia diminuir o cuidado que o autor deveria ter na escolha de escritores homens, especialmente no espaço dos países mais próximos, neutralizando em certa forma, o aspecto político.

Esse primeiro bloco de leituras se concentra no território e na vida cultural da Espanha. Afirmação sobre a qual cabe perguntar: que aspectos tem o mundo representado? As leituras, de modo geral, apresentam um universo visto através da seleção realizada por esse autor que vai fazendo opções que apontam, por vezes, à diversidade de vidas e paisagens que compõem um território, ou que tentam oferecer aos alunos uma formação cultural mais sólida e humanista. Numa aproximação inicial às leituras da lição 1 à 18, uma questão chama a atenção: os únicos textos anônimos são os que se referem ao nome da língua ou, diretamente, à Espanha e ao seu universo cultural (Don Quijote, España I, II e III, Corrida de Toros). Textos que, provavelmente, como já afirmamos, tenham sido escritos pelo próprio autor. Essa constatação nos leva a pensar que a Espanha entra no Manual, então, representada segundo o olhar de Becker que apresenta um território diverso - em España I, II e III - e questões culturais importantes e singulares, seja abordando uma das obras mais significativas da literatura espanhola - Don Quijote -, ou um espetáculo cultural “típico” - Corrida de Toros.

A Espanha é reconhecida no seu território (na paisagem e na vida) mediante as leituras que percorrem diversos espaços. Esse parece ter sido o programa itinerante do autor. As leituras España I, II e III (respectivamente das lições 4, 5 e 6) descrevem as diversas províncias, nomeando cidades e regiões e expandindo a "explicação"227. O procedimento dá lugar a uma cenografia própria de guia turístico ${ }^{228}$ - que ressalta as belezas naturais - ou de relato de viagem. De modo geral, as descrições são localizadas, focalizando cidades ou regiões, a capital, os rios, o porto, o clima, os habitantes.

As leituras acompanham o percurso de um viajante que por meio de um relato descritivo vai apresentando a diversidade de espaços, de climas e pessoas. Quebra-se assim a projeção de uma Espanha com um centro forte - sua região central -, para dar lugar a uma

\footnotetext{
${ }^{227}$ Fazemos essa afirmação inspirados em Arnoux (2010). Na análise do "Manual de Istoria de Chile” de Vicente Fidel López (1845), a autora designa esse procedimento de "modelo lexicográfico", que consistiria, justamente, em nomear a cidade e expandir a explicação sobre ela.

${ }^{228}$ Também parece prudente dizer que o trabalho do autor se filiava às tradições de leitura escolar - por ele mesmo experimentada na educação argentina - que apresentavam as paissagens do país numa forte interpelação patriótica.
} 
Espanha diversa na vida e nas riquezas. Vejamos alguns recortes que sustentam tal afirmação, começando com a leitura da lição quarta: España I. Um parágrafo breve exalta o clima (“ameno”), a luminosidade (“tierra de sol”), a natureza (“pródiga”) e a historia desse país (“España, (...) empapada de historia y de tradiciones gloriosas”). Diz-se também que encanta y deslumbra con la variedad pintoresca de sus provincias.

España, tierra de sol y de maravillas, empapada de historia y de tradiciones gloriosas; de clima ameno y naturaleza pródiga; país de música, flores, mantilla de encaje, verbenas y corridas de toros -encanta y deslumbra con la variedad pintoresca de sus provincias. Viajemos por ellas (Becker, 1947, p. 31).

Com esse nós inclusivo que convoca o leitor (“viajemos por ellas”), começa uma viagem por esa "variedad pintoresca de sus provincias” por meio desse procedimento que focaliza (numa cidade ou região) e expande. Ao norte, “Galicia -la Suiza española-, con sus ríos, sus lagos y cascadas, valles umbrosos y montes cubiertos de castaños”. Após a descrição da natureza surgem os habitantes: os "audaces pescadores [que] se hacen a la mar desde el espléndido puerto de Vigo, centro de industria notable” e as “campesinas de pañuelos rojos” diseñadas “en las vegas floridas, donde pace el ganado” (ibid..). A viagem novamente focaliza, continuando por Asturias, da qual se exalta a riqueza mineral: “Asturias, con sus ricas minas de carbón, hierro, zinc y plomo”, chegando às "Provincias Vascongadas: tierra de mineros y pescadores. Pueblecitos de gente sencilla y hospitalaria. Callejuelas empinadas y tortuosas. Costas azotadas por un mar furioso; muelles envueltos en bruma”.

Depois de apresentados os trabalhadores (mineros y pescadores), as pessoas (sencillas y hospitalarias) dos povoados, são pintadas as ruelas (empinadas e tortuosas) e a fúria da natureza (costas azotadas por un mar furioso), que deixa os muelles envueltos en bruma. “Ahora rumbo al sur:”, afirma-se a continuação, “Castilla la Vieja”. Paisagem e melancolia descritas em breves linhas:

El paisaje es límpido y diáfano. Carreteras uniformes atraviesan pueblos vetustos, de tristeza ensoñadora. Hay ventas destartaladas, mesones de anchos zaguanes, viejos palacios. Y por toda parte - una soledad de añejas tradiciones- (ibid.).

Um texto com sequências fundamentalmente descritivas que, embora com um léxico rico e abundante, parte do qual pode ser um pouco mais opaco, não apresenta muitas dificuldades para um aluno brasileiro, especialmente um aluno que por aqueles anos tinha uma formação plurilingue. Respondia-se assim à demanda de terem que ser as leituras iniciais apresentadas por meio de textos fáceis em prosa ou em verso. 
España II, a leitura que inicia a lição quinta, dá continuidade à viagem empreendida pelo leitor junto ao narrador, agora em direção à capital, Madrid, ampliando as imagens (variadas) que o leitor vai construindo:

Lejos, en la dirección de Portugal, quedó la sabia Salamanca. Atravesemos el nevado Guadarrama. He aquí la capital del país - Madrid - con su rico Museo del Prado y la célebre Puerta del Sol” (ibid. p. 34).

Novamente as pessoas, o clima e a paisagem: "Castilla la Nueva: hombres afables y mujeres hogareñas, discretas. El sol ciega con sus vivas reverberaciones el árido paisaje de la Mancha, seca y desnuda, por donde el hidalgo manchego paseó su genial locura”. E, novamente, a viagem continua em direção ao sul:

Y, otra vez, rumbo al sur. Surgen las llanadas de Valencia, con sus campos de arroz y sus naranjales. En Alicante, famosa por su turrón y sus vinos, hay frutos exquisitos. No tienen árboles sus colinas, pero en las huertas, en los barrancos y en las laderas -florecen granados, algarrobos, higueras, viñas, datileras, olivos-. Y jóvenes de peregrina y delicada belleza cogen palmas y azahares.

En Murcia el aire cálido anuncia el África cercana. Bulle el agua en las largas acequias, por entre huertas exuberantes, donde gusanos de seda tejen sus capullos” (ibid.).

Os procedimentos são os mesmos, a focalização e a expansão: "Valencia, con sus campos de arroz y sus naranjales”. “Alicante, famosa por su turrón y sus vinos (...), “ Murcia (...)”. As sequências descritivas, fortemente marcadas por substantivos e adjetivos, permitem a construção de imagens que vão compondo, ao longo da trilogia, uma Espanha variada em seu clima, suas paisagens e produtos, seus habitantes e os trabalhos por eles realizados, as atividades agrícolas, e a indústria com o seu esplêndido porto.

Finalmente, para fechar a trilogia, a leitura da lição sexta - España III - que nos faz viajar por Andaluzia, Córdoba e Sevilha, Granada, Alhambra:

Y, en el fin, bajo un cielo azul purísimo -Andalucía, graciosa y sonriente. Aquí natura derrocha sus dones: minas de oro y plata, ganados, cereales, olivos, remolacha, naranjos, limoneros, todas las frutas tropicales. ¡Y hasta caña de azúcar!

En medio de olivares, ambas a orillas del Guadalquivir, descansan Córdoba y Sevilla. Córdoba, con sus sierras fragosas, pobladas de pinos, sus huertas opulentas, sus mujeres hábiles y laboriosas en el hogar. En la ciudad, tras las murallas moriscas, se yergue la magnífica Mezquita (hoy Catedral), el templo más grande de los árabes en España.

Y, al pie de la Sierra Nevada: Granada, la joya de la arquitectura árabe, donde los fantásticos palacios de la Alhambra y del Generalife sueñan gloriosos recuerdos de tiempos lejanos (ibid., p. 37-38).

Andaluzia, “graciosa y sonriente”, é o lugar onde a natureza “derrocha sus dones”, e junto às riquezas naturais os vestígios do domínio árabe na Espanha: a "magnífica Mezquita” e Granada, “la joya de la arquitectura árabe”. 
Nessas leituras ancoradas no território da Espanha, funciona claramente um discurso turístico. A análise dessa trilogia nos permite observar a operação que leva adiante o trabalho de escrita dando visibilidade a um modo particular de conceber a linguagem e a relação com o mundo. A escrita de Becker se vincularia a uma mimese realista que interpreta que a linguagem é transparente e que, desse modo, descreve e nomeia o mundo tal qual é. Tratar-se-ia de um realismo inócuo, que traz uma natureza idealizada e na descrição das paisagens apresenta todo como estabilizado, sem nenhum tipo de contradições ou problemáticas e criando a ilusão de que o mundo é esse que está sendo mostrado. Essa narrativa realista está atravessada por um olhar que apresenta habitats, as pessoas com seus trabalhos, o clima, as paisagens. Se essa mimese realista se apresenta como operação no funcionamento que atravessa as leituras España I, II e III, outros funcionamentos, quase opostos a ele, com um eu que exalta o próprio olhar, num tom quase romântico e de narrativas menos inócuas atravessam outras leituras da obra.

Os outros dois textos que complementam a série de cinco que abordam questões da historia e a cultura da Espanha são Don Quijote de la Mancha (segunda lição) que já se desloca, mesmo que suavemente, desse olhar idealizado e Corrida de Toros (lição onze). Desses textos propomos apenas algumas observações. A leitura da segunda lição apresenta Don Quijote como “la suprema invención de España” e, depois da Biblia, como “el más alto monumento literario de todos los tiempos” (ibid., p. 25). Traduzido a muitas línguas e de amplíssima circulação ("Se lo ha traducido a muchos idiomas. Y ha sido leído y comentado en todos los continentes”). Lido por todos (“Niños y grandes se han reído de sus aventuras. Adolescentes, sabios y políticos, literatos y filósofos -con emociones distintas-, se han detenido a meditar, gravemente, ante sus páginas” [ibid.]), a tragicomédia - diz a voz narrativa - fez circular pelo mundo a suavidade da mensagem e o enigma e a gloria da obra ("Grande y bella, irónica y profunda, la tragicomedia de Cervantes ha paseado por el mundo entero la dulzura y amenidad del mensaje, su humorismo genial, el enigma sutil de su significado y el imperio avasallador de su gloria”). O texto não só fala da variedade de leitores, das emoções que produz e de línguas às que foi traduzido Don Quijote, mas também, finalizando, expressa a contradição da vida da Espanha e da humanidade e a contradição do esplendor e a decadência do mundo:

Don Quijote y Sancho Panza: sueño heroico de quimeras y escepticismo prudente, fantasía divina y cruda realidad -una lección inmortal para todos los mortales. Como la vida de España, como la historia de la propia 
humanidad, el Quijote es el símbolo contradictorio de un mundo de esplendor y decadencia, de luz y de sombra, de amargura y fe (ibid.).

Como em muitas das leituras do livro, a da lição 11, Corrida de Toros (ibid. p. 53), prevalecem as sequências descritivas, com alguns toques narrativos. O texto parece apresentar uma sequência fotográfica de um dos eventos culturais mais importantes da Espanha. A “abigarrada multitud” que “se apiña en las gradas del vasto anfiteatro”. "Sombreros de alas anchas y rectas", para se referir à diversidade de homens que assistem ao evento; e "cabezas femeninas cargadas de rosas y rojos claveles; mantillas de encajes” para falar das mulheres. Textos que descrevem os costumes e os espaços.

Além desse eixo (o território e as práticas culturais da Espanha) que reúne as leituras mencionadas, reconhecemos outro tópico que foca mais diretamente a formação dos adolescentes: o ensino da vida e a anulação da fantasia, que se apresenta como temática nas leituras Caperucita, de Francisco Villaespesa - lição 7 (ibid., p. 40) -, e La Paloma azul, de Emilia Pio Baroja - lições 17 e 18 (ibid., p. 73 e 75), leituras que também deslocam a mimese realista. Vale mencionar que na última delas, a anulação da fantasia vem após uma exaltação romântica da imaginação infantil.

Esse primeiro bloco é o que permanece na última versão do livro, circulando assim por quase cinqüenta anos, por isso nos detivemos mais na sua apresentação. Sobre o segundo, propomos algumas observações que nos parecem pertinentes para compreendermos os efeitos que as sucessivas políticas linguísticas tiveram no processo de gramatização da língua e esse, na produção de continuidades, rupturas e deslocamentos.

\subsection{O segundo bloco de leituras: Hispano-américa}

As leituras que iniciam as lições do segundo bloco (de 19 a 30) são as seguintes: 19. El descubrimiento de América, 20. Los indios de América (José Martí, cubano), 21. Visión de Hispanoamérica, 22. San Martín y Bolívar (B. Vicuña Makenna, chileno), 23. México (Carlos Castillo, mexicano), 24. La rosa blanca (José Martí), El sueño (Rafael Alberto Arrieta, argentino), Meciendo (Gabriela Mistral, chilena), Marzo (Juana de Ibarbourou, uruguaia), 25. El gaucho, 26. El rodeo (Adaptado de Ricardo Güiraldes, argentino e Rómulo Gallegos, venezuelano), 27. Las cataratas del Iguazú (José Vasconcelos, mexicano), 28. Nieve en los Andes, 29. Buenos Aires (Roberto F. Giusti, argentino), 30. Iberoamérica (Franco e Rodríguez, argentinos). Essas leituras estão presentes na versão de 1947 e o trabalho de reformulação as omite da última versão. 
Observamos que nesse bloco, Hispano-américa aparece no centro das composições, seja no universo de autores escolhidos ou nas temáticas abordadas: espaços (cidades, países ou belezas naturais), costumes, personagens (próceres dos processos independentistas ou um homem do campo), tradições e a própria história. Como dissemos, esse aspecto estabelece um claro equilíbrio com o primeiro bloco, em que as temáticas se referiam à Espanha e sua vida cultural. Assim, em diversos momentos, as leituras do primeiro e do segundo bloco poderiam ser pensadas numa horizontalidade. É o caso de El rodeo ou inclusive El gaucho, leituras que poderiam ser pensadas em relação com Corrida de Toros. Da mesma forma que México, Buenos Aires, Nieve en los Andes e Las Cataratas del Iguazú, poderiam, na horizontalidade, ser pensadas conjuntamente com Espanha I, II e III. Essa divisão em blocos nos leva a perguntar: como apresentam esse outro mundo as leituras do segundo bloco?

Observemos primeiro que em contraposição ao olhar realista presente nas sequências descritivas que compõem algumas das leituras do primeiro bloco, relativamente fáceis para um aluno brasileiro; as do segundo apresentam outro funcionamento: pontos de vista, descrições mais densas e vocabulários menos acessíveis (ou transparentes). Vejamos por exemplo as duas primeiras e suas visões contrapostas. El descubrimiento de América, da lição 19, provavelmente escrita pelo próprio Becker e Los índios de América, da 20, de José Martí. A primeira traz a visão de um narrador identificado com o descobrimento e com a figura de Colón:

\footnotetext{
Madrugada del 12 de octubre de 1492.

Tres carabelas de Castilla -la Santa María, la Pinta y la Niña- surcan el mar desconocido. Al bordo de la primera, un audaz navegante teje sus sueños de visionario. Es Cristóbal Colón, el genial marino genovés, que vela en la última noche de una era que agoniza. ¡Cuántas oposiciones, hasta entonces, cuántos años de largas peregrinaciones y penurias, cuántas luchas y sacrificios! Pero, al fin, ya se aproxima la hora gloriosa de su triunfo, que es también la hora suprema del destino de España (Becker, 1947, p. 77).
}

A exaltação do marino genovês e da epopéia do "descobrimento" se reitera em outros fragmentos da leitura: "Este es el hombre que dará a España un mundo”, “todo es oscuridad y quietud en esta noche histórica”, “los ecos agoreros de un disparo retumban, por primera vez, en el Nuevo Mundo. Ha empezado una nueva era” (ibid. 78). Fala-se de Colón e da epopéia do descobrimento e da nova era que começa nessa noite histórica. Desse novo mundo nada se diz.

O começo da próxima leitura, um texto de Martí, como antecipamos, deixa clara a visão contraposta à qual nos referíamos: 
No habría poema más triste y hermoso que el que se puede sacar de la historia americana. No se puede leer sin ternura y sin ver como flores y plumas por el aire, uno de esos buenos libros viejos forrados de pergamino, que hablan de la América de los indios, de sus ciudades y de sus fiestas, del mérito de sus artes y de la gracia de sus costumbres (ibid., 79).

O narrador do texto conta a história a partir de outra perspectiva, a de quem habitava de modos diversos as terras da América havia muito tempo: "unos vivían aislados y sencillos, como pueblos acabados de nacer (...)”, “otros eran pueblos de más edad, y vivían en tribus, en aldeas de cañas o de adobe (...)”, “otros eran ya pueblos hechos, con ciudades de ciento cuarenta mil casas, y palacios adornados con pinturas de oro (...)” (ibid.). E para finalizar, uma descrição “deles”, da sua inteligência, imaginação e inocência, da existência independente da cultura, da arquitetura e da arte:

Ellos fueron inocentes, supersticiosos y terribles. Ellos imaginaron su gobierno, su religión, su arte, su guerra, su arquitectura, su industria, su poesía: todo lo suyo es interesante, atrevido, nuevo. Fue una raza artística e inteligente (ibid.).

A leitura da lição 25 é uma espécie de homenagem a El gaucho, o homem do campo, “altivo y sereno”, “leal, hospitalero, sufrido y valiente”. Uma descrição detalhada da vestimenta ("viste chiripá o bombacha, con cinto cairelado de lentejuelas y monedas de plata. Calza altas botas de potro y espuelas”), dos acessórios (“usa chambergo, vincha y un ancho pañuelo anudado al cuello"), das ferramentas ("trae facón, lazo y boleadoras”) e do seu instrumento musical (“y no se olvida de la guitarra”), vai construindo a imagem do gaucho e contando as transformações desse homem do campo com as próprias transformações da nação ("no es más el héroe legendario, hazañoso, atajador de malones y hacedor de fronteras”, ahora “es el hombre del campo: resero, domador, trabajador de estancia”) (Becker, 1947, p. 89).

Alguns outros textos percorrem as belezas da natureza - "Las cataratas del Iguazú", "Nieve en los Andes" - ou espaços de uma cidade - "Buenos Aires” - ou de um país - "México”. A leitura da lição 22 homenageia dois importantes próceres das independências - “San Martín y Bolívar”.

Mas, não estando essas leituras na última versão, desaparece a projeção equilibrada da Espanha e de Hispano-américa, fato que afeta a diversidade. Isso parece reforçado pelo desequilíbrio também existente na última seção do livro: Breve Antología Poética de autores españoles e hispanoamericanos. Embora Becker aborde nessa seleção uma literatura prestigiosa de época e textos relativamente contemporâneos, dos 21 textos: dois são de autores anônimos, quatorze de autores 
espanhóis $^{229}$, três de autores argentinos ${ }^{230}$, um de autor nicaragüense (Rubén Darío) e, outro, de autor mexicano (Amado Nervo). De modo geral pode-se afirmar que a literatura espanhola, com autores especialmente ligados ao romantismo e à geração de 98 e a escritores que produzem ao longo do século XX está mais representada. Vale lembrar ainda, para finalizar, que nessa última versão em que as temáticas que giram ao redor de Hispano-américa são silenciadas, também são silenciados os conflitos linguísticos entre as posições puristas da Academia que chamava de "vícios" alguns aspectos da língua que o autor reconhecia apenas como modalidades fonéticas próprias de diversas regiões.

\section{Os provérbios: projeção e interpelação do destinatário}

Após cada uma das leituras que iniciam as lições, o Manual apresenta um provérbio. Em seu estudo sobre a enunciação proverbial, Santos (2004, p. 12) afirma que o provérbio “é caracterizado por uma faceta didática e moralizante”. Existe uma ideologia além de uma vocação pedagógica que se manifesta na seleção e na própria presença do provérbio nas lições. Coincidimos com a autora citada (ibid., p. 9) quando afirma que a enunciação proverbial é um lugar em que “determinados valores sociais são reproduzidos por uma voz coletiva”, mas entendemos que esse caráter universal, atemporal e impessoal do provérbio é um efeito do próprio funcionamento desses enunciados na memória. Os provérbios incluídos no livro também ampliam o que a Gramática de Nascentes e a primeira versão da obra de Becker propunham. Agora, além das leituras, esses provérbios que flutuam fora de um texto, colocam o estudante em contato com outras formas de compreender o mundo. E dizemos “outras formas” em plural, já que pelo seu caráter polissêmico, aos mesmos provérbios podem ser atribuídos interpretações e sentidos diferentes. A sua materialidade (às vezes vinculada a um funcionamento metafórico) dá margem para essas interpretações diversas. Para fazermos algumas considerações (dentre outras possíveis), transcrevemos a série inteira

\footnotetext{
${ }^{229}$ Gutierre de Cetina, Lope de Vega, Lupercio Leonardo de Argensola, Calderón de la Barca, Adolfo Bécquer, Gaspar Núñez de Arce, Francisco Villaespesa, Antonio Machado, Juan Ramón Jiménez (2), Federico García Lorca (2), Gerardo Diego.

${ }^{230}$ Enrique Banchs, Rafael Alberto Arrieta, Alfonsina Storni.
} 
dos provérbios presentes nas duas versões (1947 e posterior a 1961) ${ }^{231}$ com o número que corresponde à respectiva lição:

1 - Donde hay una voluntad, hay un camino.

2 - Mira a la luz de frente y las sombras quedarán a tus espaldas.

3 - Dos personas miran afuera a través de la misma reja: una ve el fango y la otra las estrellas.

4 - No sabe hablar quien no sabe callar (Pitágoras).

5 - Creo que si miráramos siempre al cielo, acabaríamos teniendo alas (Flaubert).

6 - Quien no ha visto Sevilla, no ha visto maravilla.

Quien no ha visto a Granada, no ha visto nada.

7 - La felicidad no es cosa fácil: es difícil encontrarla en nosotros mismos e imposible hallarla en otra parte.

8 - Las estrellas no temen parecer gusanitos de luz (Rabindranat Tagore).

9 - La libertad no consiste en hacer lo que se quiere, sino en hacer lo que se debe.

10 - Morir ignorante habiendo tenido capacidad para ser sabio, eso sí que es una tragedia humana.

11 - En materia de carácter, modales y estilo, la simplicidad es lo supremo por excelencia.

12 - La adversidad es la piedra de toque del carácter.

13 - Dios hizo el campo, el hombre la ciudad.

$14-$

15 - Quien dice lo que quiere oye lo que no quiere.

16 - Piensa en lo que puedas hacer mejor, asegúrate de que realmente es eso y hazlo con todas tus fuerzas.

17 - Quien nunca juega el papel de tonto, no es tan sabio como se cree.

18 - Ni el brillante se pule por si, ni el hombre se perfecciona sin experiencia ${ }^{232}$.

${ }^{231}$ Aqui nos concentramos nos provérbios das lições que permanecem na última versão, mas vale à pena mencionar que na de 1947 os provérbios se multiplicam em diversos espaços do livro, permitindo-nos inferir que estão na base de essa formação que interpela os estudantes e que, além de uma formação patriótica e humanística, tentava colocá-los em contato com outras formas de compreender o mundo. A multiplicação de provérbios também pareceria ter essa função.

${ }^{232} \mathrm{O}$ manual de Alvarez Calleja também traz provérbios ou refrães populares nas lições. Nas análises, observamos certas diferenças com relação à seleção realizada por Becker, projetando, dessa forma, outra representação do destinatário. De modo geral não trazem uma reflexão sobre a condição humana e, bebendo em outro corpus cultural, não apresentam nem a sofisticação nem a elevação nem a reflexão aprofundada dos provérbios do livro de Becker. Focando outros aspectos da vida, parecem atuar sobre os comportamentos. Transcrevemos alguns exemplos: "Quien mucho duerme, poco aprende” (Calleja, 1946, p. 13); “Fue por lana y salió trasquilado” (ibid. p. 20); “Dime con quién andas y te diré quien eres” (ibid., 
Sobre esses provérbios inseridos no Manual com finalidade pedagógica e formativa, fazemos possíveis leituras, sabendo que outras poderão ser acrescentadas. Leituras possíveis que buscam nas entrelinhas e nesse contexto escolar, a projeção e interpelação do destinatário: o aluno do ensino médio.

O primeiro desses provérbios (Donde hay una voluntad, hay un camino) apresenta dois elementos entrelaçados que de modos diferentes estão presentes em vários dos outros: a determinação de enfrentar a vida se apresenta como necessária para traçar percursos. Já o segundo reforça a determinação presente no primeiro (Mira a la luz de frente y las sombras quedarán a tus espaldas). O terceiro (Dos personas miran afuera a través de la misma reja: una ve el fango y la otra las estrellas) se refere à relatividade de toda e qualquer percepção do mundo e como, a partir de uma mesma posição e observando através da mesma grade, o objeto visto pode adquirir formatos bem diferentes. Desse enunciado surge também uma possível pergunta: que olhamos quando olhamos? Onde está o foco, onde cada uma dessas pessoas que olham desde o mesmo ponto põe o foco. A subjetividade surge como um núcleo de reflexão. No quarto provérbio está presente a questão da linguagem e do seu controle por parte do homem moderado (No sabe hablar quien no sabe callar - Pitágoras) - reforçado pelo provérbio décimo quinto. As palavras de Flaubert, no quinto, ressaltam que ter objetivos elevados nos engrandece (Creo que si miráramos siempre al cielo, acabaríamos teniendo alas). Mas se são valorados os objetivos da vida, o modo de olhar e a subjetividade de quem olha, também são valorados espaços específicos, por meio de uma homenagem a duas grandes cidades marcadas por uma trajetória histórica singular (Quien no ha visto Sevilla, no ha visto maravilla. Quien no ha visto a Granada, no ha visto nada.). O provérbio também apresenta o relativo das apreciações dos homens que não podem escapar a seu próprio lugar de percepção e enunciação. A felicidade não é coisa fácil, diz o sétimo, que prefigura o desafio e a dificuldade: é uma experiência subjetiva que cada um deve buscar em si mesmo e, se isso é difícil, impossível é encontrá-la fora de nós (La felicidad no es cosa fácil: es difícil encontrarla en nosotros mismos e imposible hallarla en otra parte). Sem dúvida depende, de novo, de uma vontade determinada. A citação de Rabindranat Tagore traz a problemática do ser e do parecer no oitavo: não importa o que os outros possam pensar, o que cada um pareça ao o olhar do outro, mas 
o que cada um é (Las estrellas no temen parecer gusanitos de luz). No nono está presente também a questão do “deber ser” (La libertad no consiste en hacer lo que se quiere, sino en hacer lo que se debe - haveria algo mais forte que as próprias pulsões internas: a sociedade, a pátria?). A valoração do conhecimento no décimo (Morir ignorante habiendo tenido capacidad para ser sabio, eso sí que es una tragedia humana) junta-se ao patriotismo do provérbio anterior, integrando duas questões fortemente instaladas no âmbito escolar. Assim como também, no décimo primeiro, a ideia da simplicidade na formação do caráter (En materia de carácter, modales y estilo, la simplicidad es lo supremo por excelencia) e a necessidade de enfrentar as adversidades, no décimo segundo (La adversidad es la piedra de toque del carácter).

O décimo terceiro traz uma questão diferente às já abordadas: o paralelismo (e a diferença) entre Deus e o homem, e a ideia de que o homem, por tanto, teria algo de divino (Dios hizo el campo, el hombre la ciudad). O décimo quinto apresenta novamente os sentidos de um homem responsável pelo seu dizer e de controle da palavra própria (Quien dice lo que quiere oye lo que no quiere). O décimo sexto reforça, mais uma vez, a determinação para enfrentar os afazeres da vida (Piensa en lo que puedas hacer mejor, asegúrate de que realmente es eso y hazlo con todas tus fuerzas).

Finalmente, e por meio de uma comparação, a ideia de que o homem, assim como um brilhante que tem que ser polido para brilhar, precisa de um apoio, de trabalho e de experiência ( $N$ i el brillante se pule por sí, ni el hombre se perfecciona sin experiencia). A escola, nesse sentido, teria uma tarefa nesse aperfeiçoamento.

De forma geral, esses provérbios fortemente estabilizados na memória, abordam questões sobre a condição humana e a sua complexidade, a relação com os outros e a compreensão do mundo. Neles, vemos projetado o destinatário - o estudante secundário que tem que ser formado numa sólida cultura geral - e a orientação do sentido da interpelação da qual é objeto: um sujeito simples, moderado, forte, com domínio sobre a própria sensibilidade e emoções, que rechaça a vaidade, responsável pelas suas palavras e pelo seu destino, determinado, decidido e para quem o conhecimento é importante; um tipo de homem que a escola deveria cultivar e desenvolver. Um estudante projetado na sua formação mais ampla, uma formação humanística que implicava, segundo expressado na Exposição de Motivos da Reforma Capanema (1942), a compreensão “do valor e do destino do homem”, “do que é o homem” e de “uma concepção do ideal da vida humana”. Alinhados com as diretrizes do Estado, os provérbios do livro de Becker parecem ir nessa direção. 


\section{Os exercícios: o papel das línguas e dos tópicos gramaticais}

Se a série de provérbios nos permitiu sondar a projeção do destinatário e da sua formação, a análise dos exercícios nos permitirá adentrar nas representações das línguas e do trabalho com elas. Os exercícios abordam de diferentes formas os tópicos gramaticais em foco em cada uma das lições. Pela exigência que implicam, interpretamos que pressupõem, por um lado, que os aspectos envolvidos tenham sido trabalhados nas aulas e, ao mesmo tempo, um aluno competente linguisticamente e um professor autônomo. Isso já tinha sido antecipado por Becker no Prefácio das primeiras edições: “Supõe-se que o aluno já saiba o que é, por exemplo verbo e o que significam os diversos modos, tempos, números e pessoas” (Becker, 1945, p. 11). Becker tinha antecipado um aluno e para ele propõe os exercícios. Anuncia-se, assim, a ativação dos conhecimentos em/do português e a projeção dos mesmos no estudo da língua estrangeira.

Como uma espécie de regularidade, três grandes propostas compõem o Manual. Uma delas (1) apresenta textos ou frases em espanhol com lacunas que devem ser completadas segundo anunciado na consigna. Esses exercícios põem o foco, de forma específica, no tópico trabalhado na respectiva lição. A outra proposta (2) solicita aos alunos algum tipo de trabalho de tradução ao espanhol de frases ou de fragmentos e sintagmas específicos, apresentados em português entre parênteses. A particularidade é que o que deve ser traduzido (em sua grande maioria do português ao espanhol) não é um texto - que implicaria trabalhar com elementos ainda desconhecidos -, mas aspectos específicos da língua considerados centrais em cada lição por meio de frases que correspondem sempre ao tema gramatical abordado. As traduções parecem buscar estabilizar e exercitar o aprendizado gradual e específico da língua ensinada. Essas propostas permitem pensar não só o papel que esses exercícios de tradução desempenham no Manual (o reforço do aprendizado e a exercitação de pontos considerados centrais na gramática do espanhol) ${ }^{233}$, mas também o lugar da língua portuguesa no aprendizado e no trabalho de comparação contrastiva. A terceira proposta (3) remete diretamente à leitura inicial da lição, pedindo o reconhecimento nela de algum aspecto específico do funcionamento linguístico. Isso permitiria pensar que em alguns casos a leitura teria sido escolhida também por apresentar, na sua materialidade,

\footnotetext{
${ }^{233}$ O livro de Álvarez Calleja também apresenta exercícios de tradução, em sua grande maioria pequenos textos que se por um lado apresentam a "exercitação" do vocabulário (e não da questão gramatical, como proposto no livro de Becker) deixam dúvidas sobre como se espera que o aluno resolva as questões não trabalhadas ainda, ou as diversas estruturas específicas da língua.
} 
o tópico proposto na lição, possibilitando ver seu funcionamento na "língua em uso", neste caso, em certas práticas literárias.

Transcrevemos alguns dos exercícios que mostram o funcionamento dessas três propostas regulares. As primeiras lições apresentam o artigo definido e indefinido com as contrações, as regras de eufonia e o plural de substantivos e adjetivos. Esses tópicos são exercitados de forma específica do seguinte modo e nessas três modalidades de exercícios. Vejamos a lição 2:

Ejercicios [proposta 1]

1. Reemplacen los puntos suspensivos por el artículo definido, o por la contracción al o del, como convenga:

$$
\begin{aligned}
& \text { Tal vez ...... pájaro cante } \\
& \text { para ...... ramas ..... roble. } \\
& \text { Tal vez ...... río murmure } \\
& \text { para ...... piedras que roe. } \\
& \text { Tal vez ...... viento se queje } \\
& \text { para ...... cruz de ...... torre. } \\
& \text { Tal vez nosotros callemos } \\
& \text { puesto que tú no nos oyes. }
\end{aligned}
$$

Fernández Moreno (Becker, 1947, p. 27) ${ }^{234}$.

2. Sustituir los puntos suspensivos por el artículo definido o indefinido, o por la contracción al o del, como convenga -en los siguientes refranes y máximas:

...... hábito no hace ....... monje

Siempre quiebra ...... soga por ....... más delgado.

...... esperanza es ...... buen desayuno; pero ...... mala cena.

Más vale ....... amigo que pariente ni primo.

...... dicho ...... hecho hay mucho trecho.

...... gota constante horada piedras.

....... hombres, cuando reciben ...... mal, suelen escribirlo en

...... mármol; cuando reciben ....... bien, en ....... polvo.

(da versão final, Becker, 1988, p. 29).

Esses exercícios parecem buscar a estabilização e fixação das questões abordadas, de forma especial, os artículos definidos e indefinidos e as contrações. Embora não anunciado na consigna do exercício, também se trabalha o artículo neutro lo, apresentado na própria lição como "legítimo orgullo de la lengua castellana” que "no tiene forma propia en las demás lenguas neolatinas". "Se ha producido en ellas", afirma-se, "la confusión gráfica entre el neutro y el masculino” (Becker, idid. p. 28). A continuação se explica seu uso quando se antepõe a adjetivos para serem convertidos em substantivos

\footnotetext{
${ }^{234}$ Na versão final as consignas apresentam os verbos em infinitivo. Também é bom notar que na versão final não aparece o nome do autor do poema.
} 
abstratos: "lo hermoso (equivalente a la hermosura), lo difícil (equivalente a la dificultad)” (ibid.), e seu uso (antigo) com substantivos, advérbios e outras locuções.

Das duas últimas versões vão desaparecendo aspectos interessantes que possibilitam uma melhor compreensão do tópico tratado. Por um lado, uma explicação que aborda a diferença entre “o adjetivo substantivado” e o próprio substantivo. Nas três versões se davam os seguintes exemplos: "lo hermoso (equivalente a la hermosura), lo difícil (equivalente a la dificultad)” (Becker, 1945, p. 41; 1947, p. 26; 1988, p. 28). No entanto, das duas versões finais desaparece a diferença dos dois usos, que em 1945 o autor apresentava em palavras de Cuervo:

Aquí notaré - diz Cuervo - que el adjetivo neutro presenta las cualidades más en abstracto que el sustantivo correspondiente: al decir LO BUENO, se ofrece al entendimiento una cualidad claramente desprendida de un sujeto; en LA BONDAD, por el mero hecho de su carácter léxicamente sustantivo, no aparece tan a las claras la falta del sujeto (Becker, 1945, p. 41).

E no caso específico da versão final, o trabalho de reformulação retira os exemplos do uso da forma neutra com substantivo (um uso mais antigo que poderia deixar um professor com certas dúvidas), presentes nas duas primeiras com os seguintes exemplos: “Todo fue grande en aquel príncipe, LO Rey, LO capitán, LO santo (Bello)” (Becker, 1945, p. 41; 1947, p. 26). Evidentemente, embora importante e interessante para aprofundar questões e sutilezas gramaticais, o tempo atribuído ao ensino e as diretrizes ministeriais que ampliavam o modo de trabalhar a língua exigiram cortes e as opções para realizar os cortes também estiveram dirigidas a essas explicações sobre aspectos mais específicos e sutis do funcionamento da língua (como as palavras de Cuervo) e usos menos comuns (como os exemplos do artigo neutro com substantivo, comprometendo neste caso a compreensão).

Voltando aos exercícios, na terceira lição aparecem de forma combinada as três propostas, na ordem apresentada a continuação:

1. Decir cuántas veces se observan las reglas de eufonía en la lectura de esta lección (CALMA). [proposta 3]

2. Traducir al español las siguientes frases:

A água soa na praça. A boa (buena) água. Ramagem e hera. Cipreset alto e hirto. A larga vidraça. Muro ou horta. [proposta 2]

3. Colocar el artículo determinante que corresponda y completar los adjetivos:

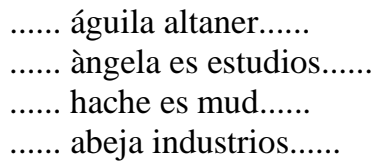

...... hacha filos......
..... ancla pesad......
..... hambre canin......
...... alta torre 


\section{Traducir al español:}

Uma águia altaneira. Um machado afiado. Uma âncora pesada. Uma abelha. Uma alta torre. Uma fome canina. [proposta 2]

5 Las conjunciones (en bastardilla) están en portugués. Tradúzcanlas al castellano.

Juan $e$ Ignacio. Firme $e$ hialino. Mujer ou hombre. Alcohol $e$ yodo. Plata ou oro. Caballo $e$ yegua. Trabajador $e$ inteligente. Nariz ou oído. Aguja $e$ hilo. Martillo e yunque. Recordar ou olvidar. [proposta 2]

(Becker, 1988, p. 32-33; Becker, 1947, p. 30).

Dentro do primeiro subgrupo, que propõe exercícios só utilizando o espanhol, existem alguns que, buscando por o aluno em contato com um contexto cultural mais amplo, combinam o ensino da poesia com o ensino da gramática. É o caso de um dos exercícios da lição 9, em que os tópicos gramaticais abordados são os possessivos e demonstrativos:

Sustituyan los puntos suspensivos por demostrativos o posesivos, y digan quién es el autor de este soneto:

Alma ...... gentil que te partiste de ...... vida mortal tan brevemente, descansa allá en el cielo eternamente y viva yo en la tierra siempre triste.

Si en el asiento etéreo a do subiste memoria de ...... vida se consiente, nunca te olvides del amor ardiente que en ...... ojos tan puro y firme viste.

$\mathrm{Y}$ si ves que algo puede merecerte el inmenso dolor que me ha quedado del daño irreparable de perderte, ruega al Dios, que ...... años ha abreviado, que tan presto de aquí me lleve a verte cuan presto de ...... ojos te ha quitado.

(Becker, 1947, p. 49; Becker, 1988, p. 52).

Vejamos que a consigna solicita do aluno dizer a qual autor pertence o soneto, o que parece também um indicador do trabalho que o autor propunha transversalmente com a literatura.

Os grupos de exercícios propostos estão pautados pelos tópicos gramaticais trabalhados, o que nos parece uma regularidade geral dos manuais que surgiam por aqueles anos. Havia uma necessidade de prática com a língua, prática escrita, facilitada pela realização dos exercícios e prática oral, abordada de outros modos. 


\section{As notas explicativas da primeira versão: o que se apaga na redução}

As notas explicativas da primeira versão "esclarecem pormenores ou pontos de vista pessoais”, diz Becker (1945, p. 11) no Prefácio da obra. Sendo próprias de uma gramática, podemos observar que aprofundam e expandem as reflexões sobre a língua e sua historia. Nesse sentido, os apagamentos produzidos no trabalho de reformulação omitem o aprofundamento existente na primeira versão sobre o conhecimento da língua, especialmente ao fazer registros da sua historia. O livro tinha estado presente nas práticas de ensino e a experiência da combinação do tempo curto destinado às aulas, com as diretrizes que exigiam extrapolar o puramente gramatical e adentrar em outras questões da língua (oralidade, historia das literaturas, leituras, exercícios), e ainda um mercado editorial que também exercia suas pressões, parecem ter levado o autor a essas reduções, omitindo um trabalho mais reflexivo e histórico com a língua.

Lendo as notas escritas por Giusti e pelo próprio autor (com maior frequência), mas também por Bello e pela Academia, encontramos algumas regularidades. Por um lado, há aquelas que ampliam algum aspecto do tópico tratado, acrescentando saberes, como é o caso da nota de Giusti que se refere aos ditongos e tritongos (Becker, 1945, p. 20), ou a do próprio autor ao explicar as exceções de algumas regras de eufonia (ibid., p. 23) e, também, das que introduzem a explicação de algum aspecto em desuso, como a nota sobre o pronome "cuyo" na qual se afirma que, embora em desuso como interrogativo, tinha sido usado pelos clássicos com esse sentido (ibid., p. 34). Outras notas apresentam a comparação contrastiva, gesto regular na obra: ao abordar as vogais, uma nota do próprio Becker traz uma comparação fonética do /e/ e do /o/ em espanhol e português e do uso do trema (ibid., p. 20); nesse mesmo sentido ao apresentar o funcionamento do acento agudo, o autor comenta:

El acento, en castellano, indica apenas la sílaba tónica. No se lo confunda con
el acento AGUDO del portugués que señala abertura de la vocal. Recuérdese
que en español las vocales son siempre uniformes” (ibid., p. 31).

Um terceiro grupo amplia o gesto de comparação contrastiva (pela semelhança ou dessemelhança) de diversos modos. Ao apresentar as consoantes, na explicação do funcionamento do “h”, se parte do reconhecimento de haver uma fonética muda em ambas as línguas e se lança uma hipótese com base na pronúncia latina acerca da tendência - observada provavelmente ao longo da experiência docente do autor - de 
pronúncia “errada” por parte do estudante brasileiro. Como em outros casos, neste também a explicação adentra na história da língua:

A pesar de ser letra muda en ambos idiomas, los brasileños tienen una curiosa propensión a aspirar la $h$ de las palabras españolas sobre todo las iniciales. Repárese en que muchas haches iniciales provienen de una $f$ latina, que se ha conservado en la lengua portuguesa, como hablar (falar), hacer (fazer), hada (fada), hembra (fêmea), hijo (filho), hilo (fio), hermoso (formoso), higo (figo), hambre (fome), hincar (fincar), humo (fumo), hoja (fôlha), etc. Parecería, entonces, que un "instinto etimológico" tratase de devolverle a la h su calidad de consonante. Y el impulso subconsciente del lector brasileño se concretizaría en el único modo de conseguirlo: la aspiración de la $h$.

Sea como fuere, habrá que combater (sic) enérgicamente esa extraña tendencia fonética (Becker, 1945, p. 21-22).

As notas de um quarto grupo explicam, expandem, aprofundam e trazem o debate com a Real Academia Espanhola, por meio de afirmações que se distanciam das realizadas por essa instituição. Exemplo delas são as já apresentadas no item 3 sobre o seseo e o yeísmo (que abordam o conflito linguístico, fundamentalmente entre Espanha e América), e também aquela que amplia a explicação de $v=b$. Nela, se fala da história da língua e do que o autor considera um empobrecimento fonético do espanhol ao longo dos séculos. Vale aqui sua leitura:

No estará demás recordar que "los gramáticos de los siglos XV y XVI dicen que estas letras se pronuncian de distinta manera” (Gramática de Bello y Cuervo, pg. 11 de las Notas, Edición Anaconda, 1941).

Del punto de vista etimológico, ya se sabe que la $\mathbf{v}$ labiodental existía en el latín y se ha conservado en las demás lenguas neolatinas (portugués, francés, italiano, etc.). Es lamentable que el español constituya una excepción en este caso.

Cuanto a la tradición o al uso, ya se ha visto que no siempre se confundían la b y la $\mathbf{v}$ y lo mismo ocurre aún en ciertas regiones españolas. La propia Academia lo confiesa de forma indirecta: "Siendo en la MAYOR parte de España igual la pronunciación de la $\mathbf{b}$ y la v”... Sería excelente poder aprovechar tan oportuna inclinación fonética de la parte MENOR.

Muchas ventajas habría en ello. Se evitaría la natural confusión ortográfica entre la b y la v. Se permitiría a ciertas palabras una correcta pronunciación etimológica (valquiria, vals, levita, voltio, volteriano, Varsovia). Y, sobre todo, se enriquecería notablemente la fonética española, ya empobrecida en siglos anteriores con la pérdida de la $\mathbf{s}$ intervocálica (como en el francés rose o en el portugués casa), de la $\mathbf{x}$ análoga a la shin árabe (como en el portugués caixa), de la $\mathbf{g}$ o $\mathbf{j}$ (como en el portugués coragem e rijo), de la ç equivalente a la $\mathbf{z}$ italiana (como en zucchero). Si en nombre del "pueblo" y del "uso" -no siempre considerados en su totalidad- fueron aprobadas y sancionadas tantas innovaciones contrarias a la antigua pureza e índole del idioma, es de esperar que se imponga tendencia tan justa, necesaria y elogiable de cierta parte del pueblo y del uso.

A los que nos reprochan: ¡Influencia francesa (o italiana, o portuguesa)” no tememos responderles: -Pues, ¡bienvenida sea!, como bienvenidos fueron centenares de galicismos, italianismos y lusitanismos, que enriquecieron el idioma, y hoy ya están registrados por la severísima Academia Española” (Becker, 1945, p. 18). 
Da nota derivam diversas questões: por um lado, os dados históricos sobre as mudanças fonéticas, por outro, a parcialidade da Academia na seleção do que é feito em nome do “povo” e do "uso" nos parecendo estar implícita uma dúvida do autor sobre qual povo e qual uso estariam aí considerados. Finalmente, as “abdicações” da "severíssima” Academia, que terminou por registrar centenas de galicismos, italianismos e lusitanismos que, segundo Becker, tinham enriquecido o idioma. Observemos que no último parágrafo da nota analisada vem a tona novamente a tomada de posição do autor, já referida no item 3 deste capítulo. Numa escrita mais solta e numa sequência dialogal que parece projetada ao imaginar uma interlocução com puristas o autor muda o tom e o modo de dizer.

A reflexão em profundidade sobre a língua ativa operações metalingüísticas que estimulam o desenvolvimento cognitivo, como parte de uma formação integral. É possível que a representação do estudante e das obrigações da escola na sua formação também tenham variado com o tempo, embora não tenhamos feito um estudo mais aprofundado sobre essas questões.

Outra nota na qual se abordam as mudanças da língua ao longo da sua historia surge no capítulo dedicado ao artigo. Num dos itens do capítulo vão sendo apresentadas formas do definido que foram omitidas e a referida nota assinala essa dimensão histórica:

Se usó antiguamente el artículo con el posesivo, como aun hoy en el portugués. La Academia cita a Garcilaso “Contaréis LA MI muerte cada día (ibid., p. 41).

Além das regularidades apresentadas até aqui, as notas abordam de outros modos temáticas já presentes no livro, algumas das quais já foram tratadas neste trabalho. Uma delas traz a especificidade do aluno brasileiro e os ganhos de uma produção específica para esse aluno:

Este modo de exponer, agrupar y numerar las reglas de acentuación lo hemos organizado especialmente, para mayor facilidad de los estudiantes brasileños. En ninguna gramática española, ni aun en la de la Academia, hemos encontrado semejante forma metodizada de desarrollar ese tema (Becker, 1945, p. 31).

O autor chama a atenção para o trabalho metódico que apresenta as regras de acentuação aos estudantes brasileiros e para a ausência dessa sistematização em gramáticas espanholas, inclusive na da Academia.

Outra nota fornece orientações didáticas aos professores e novamente projeta a representação de um aluno autônomo. Ao abordar os falsos sinônimos, diz o autor:

Para familiarizar a los alumnos con estos falsos sinónimos, son recomendables ejercicios de traducción - en el aula o fuera de ella $\quad$ con oraciones que incluyan palabras como BIZARRO, CACHORRO, COPA, 
DESCOMPUESTO, DISTINTO, ESCOBA, EXQUISITO, LADRILLO, LARGO, OFICINA, PALCO, PALOS, PERO, PRONTO, PULCRO, RATO, ROJO, RUBIO, RUIN, TODAVÍA, TORPE, VASO, etc. Muy conveniente sería que los alumnos descubriesen los diversos significados y acepciones, por sí mismos, mediante libros o diccionarios, pero sin ayuda del profesor (Becker, 1945, p. 39).

Como vimos, a primeira versão do Manual apresentava diversas notas que indo de um pólo de maior tensão onde localizamos o conflito linguístico e político, a outro que aprofundava descritivamente uma questão gramatical específica, enriqueciam o conhecimento da língua e de sua história por parte de alunos e, certamente, de muitos professores.

Neste capítulo abordamos um dos manuais de maior permanência no ensino da língua espanhola, publicado em 1945 - em um contexto de abundância de oferta de livros - e reformulado pelo próprio autor em duas oportunidades. No trabalho de análise rastreamos as mudanças nas condições de produção, as possíveis representações que se materializam nas transformações operadas e as marcas que funcionaram como indícios do trabalho de reformulação da obra: mudança de gênero, omissões, cortes e agregados. A identificação de Becker com o projeto político enunciado na Exposição de Motivos da Reforma Capanema e com um Programa que projetava de forma mais ampla as práticas escolares com a língua, tiveram efeitos na primeira reformulação, de 1947. O trânsito pelos oito itens propostos para a análise nos permitiu reconhecer nessa versão uma adequação às diretrizes ministeriais. Observamos uma redução dos aspectos que abordavam de forma aprofundada a transformação da língua ao longo da história e tópicos gramaticais específicos, recortando-se assim o caráter mais enciclopédico que a primeira versão apresentava. Nessa redução, detectamos também a omissão dos conflitos no debate sobre certos aspectos da língua, apresentados por Becker na primeira versão em diversas oportunidades em que suas explicações se distanciavam dos juízos "severos” da Academia. Na mudança de gênero operada nessa reformulação, assinalamos a incorporação de leituras que introduziam cada lição, provérbios, um trabalho mais específico com os tópicos gramaticais e exercícios dirigidos à prática e estabilização dos mesmos. Além dessas transformações, na obra de 1947, observamos a existência de um equilíbrio entre as lições dedicadas a aspectos da Espanha e de Hispano-América, ao pensarmos as temáticas abordadas nas leituras e o universo de autores escolhidos. Equilíbrio que desaparece da última versão, produzida após 1961. Por aqueles anos, as condições de produção tinham mudado significativamente. As 
línguas estrangeiras tinham sido retiradas do currículo: já não havia diretrizes, não havia Programa vigente, nem uma projeção ampla dos potenciais leitores (e consumidores) do livro. Cortes editorialmente pragmáticos - na busca, certamente, de um livro mais rentável - e um trabalho de reformulação que como efeito do apagamento das questões que giravam ao redor de Hispano-América produz uma versão menos equilibrada e menos alinhada ao projeto político-educativo que em 1942 tinha incluído o espanhol no currículo da escola secundária e tinha sido o contexto imediato para a produção da obra. 
CONSIDERAÇÕES FINAIS E PROJEÇÕES 
Iniciamos a pesquisa tomando como ponto de partida uma cena contemporânea que disparou as primeiras indagações e a reflexão empreendida sobre a história do espanhol no ensino secundário brasileiro e os primeiros gestos de gramatização da língua. Para projetar o trabalho novamente em direção desse núcleo inicial, dividimos este item final em dois momentos. No primeiro, recuperamos argumentos, discussões e análises, percorrendo - embora não linearmente - o trabalho realizado, e propondo algumas conclusões sobre a inclusão da língua no ensino secundário e seu processo de gramatização. No segundo momento, nos centramos em reflexões mais amplas suscitadas ao longo do percurso que, em certa forma, projetam o trabalho ao seu ponto de partida, tentando dar conta das indagações iniciais. Fazemos uma parada nos anos do governo de Juscelino Kubitschek e construimos um final que permite recomeçar o ciclo de reflexões.

I.

Como indica o título da tese, abordamos o trabalho fundamentalmente em dois planos: o jurídico/legislativo e o da gramatização da língua, aspectos que orientaram a construção desta pesquisa e que se constituem como lugares de memória nos quais se entrelaça o histórico, o político, o social e o linguístico. Realizamos o percurso em dois períodos particulares da historia do Brasil: os anos 1920 e o que corresponde ao Estado Novo (1937-1945) durante o governo de Getúlio Vargas, os dois primeiros momentos de inclusão da língua no ensino secundário com a consequente elaboração de instrumentos linguísticos para o seu ensino. No percurso analisamos um conjunto de discursos de características heterogêneas, que se mostraram significativos para abordar a complexidade dos fenômenos envolvidos e para compreender as questões, também heterogêneas, que fomos colocando como indagações.

Um dos aspectos abordados trata das motivações governamentais, já que a inclusão e a permanência do espanhol no currículo dizem respeito a uma política de Estado. Rastreamos nos discursos os possíveis aspectos que levaram o Estado brasileiro a incluir a língua "dos países vizinhos” na grade curricular. Percorremos, assim, o arquivo jurídico/legislativo e a partir dele outros discursos que lidos em conjunto nos 
permitiram observar diferenças significativas entre os anos 1920 e a Era Vargas. Diferenças que se manifestaram nos discursos sobre a inclusão, no modo em que aconteceu essa inclusão (facultativa nos anos 1920 e obrigatória com a Reforma Capanema) e na permanência da língua na escola (cinco anos no primeiro período e quase duas décadas no segundo). Diferenças essas marcadas não só pelo lugar ocupado pela educação em cada um dos projetos de país, mas também pelas representações projetadas sobre esses países vizinhos, o lugar outorgado a eles no tabuleiro político e as relações estabelecidas. A partir dessas diferenças, projetava-se também o lugar que ocuparia a língua espanhola no currículo.

Trabalhar sobre esse plano horizontal nos levou a vincular os mecanismos de inclusão/exclusão da língua e o tipo de inclusão aos diferentes movimentos que o Brasil assumiu nas relações internacionais com os países da América Latina e também com os Estados Unidos. Nos anos 1920, o Brasil estava fortemente alinhado a uma posição subordinada aos Estados Unidos, defendendo o pan-americanismo já preanunciado quase um século antes com a Doutrina Monroe. Nesses anos, também se projetava no imaginário um Brasil “fora da América Latina”, afastado das “repúblicas caóticas” da América hispânica, “onde campeava a desordem e a fragmentação” (Prado, 2001, p. 131-132) ${ }^{235}$. Os países vizinhos ocupavam, claramente, um segundo plano nas relações internacionais. Como efeito, a inclusão da língua se mostrou "tímida”, "tênue”, uma troca de gestos diplomáticos que buscaram retribuir a iniciativa do governo uruguaio na inclusão do português e atender as demandas desse Estado para que o Brasil fizesse sua parte. E o Brasil fez: incluiu a língua no Colégio Pedro II com suas potencialidades limitadas pelo caráter facultativo (e, assim, subalterno) atribuído ao seu ensino e pela breve permanência ao interior do âmbito educativo. Apesar da brevidade, foi um gesto inaugural e começava aí, nessa sociedade e nesse colégio elitista a construção de uma memória e de uma permanência que ultrapassou os muros da escola. Excluída do ensino formal, a língua ocupou outros âmbitos e teve outras permanências, certamente menos visíveis.

O governo Vargas, sem cortar as relações com a potência do norte - que atravessam de modos diversos a história do Brasil ao longo de todo o século XX buscou dar destaque às alianças com os países da região: alianças comerciais, missões culturais, aproximações políticas. Para esses anseios de Estado explicitados nos documentos analisados, o ensino de espanhol tinha outra projeção e a obrigatoriedade

${ }^{235}$ Segundo Prado (2001), eram ideias defendidas pelos ideólogos do império que escreveram a história oficial do Brasil e defendiam a monarquia em oposição a essas "repúblicas caóticas". 
da língua nos cursos “clássico” e “científico” buscou dar conta dessa dimensão política. Nesses anos, o espanhol formou parte de um projeto político-educativo que não só instaurou a língua no currículo com caráter obrigatório, mas garantiu uma longa permanência que foi além dos períodos em que Vargas esteve no poder. Projetar a língua como um aspecto que permitiria “uma maior vinculação espiritual” com os países da região teve efeitos claros e duradouros. Uma parte da sociedade brasileira estudou espanhol no âmbito escolar no decorrer dessas duas décadas.

Em síntese, ao longo do trabalho nesse plano da tese, apresentamos as diferentes dinâmicas que em cada um dos dois períodos marcaram a inclusão da língua: pontual no primeiro, não só em termos da inclusão em uma única instituição - que embora funcionando como paradigma e modelo da educação projetava a língua para uma pequena elite -, mas também na produção de uma única gramática; e mais abarcadora e expandida, no segundo, com a ampliação do ensino médio e com a inclusão da língua como disciplina obrigatória nesse âmbito específico. A projeção de uma educação mais democrática ampliou a circulação da língua por diferentes estados e instituições, ampliou o número de alunos e, consequentemente, ampliou a produção de instrumentos linguísticos. O estudo do processo de gramatização e a aceleração da produção que marcou a passagem da existência de um único instrumento linguístico - a Gramática de Nascentes - a múltiples gramáticas e manuais foi o que nos propusemos estudar e analisar no outro plano trilhado na tese.

Como no plano anterior, também neste as entradas eram complexas. Nos anos 1920, estudamos a Gramática de Nascentes como discurso fundador da gramatização brasileira do espanhol e, dessa forma, como lugar de memória da língua e, fundamentalmente, do processo que ao selecionar e excluir determinados aspectos a vinculou a um padrão linguístico outorgando a ela um contorno específico. Nesse estudo buscamos compreender a forte adesão da obra à Real Academia Espanhola e à Gramática produzida por essa instituição em 1917, adesão anunciada pelo autor já na Introdução. Ao mesmo tempo, buscamos rastrear o que não ficava contido nesse padrão linguístico disciplinador propagado ao longo dos séculos desde a Espanha, o que estabelecia certas controvérsias e o que o ultrapassava, se afastando - mesmo que timidamente - das “severas opiniões” da instituição, como diria décadas mais tarde Idel Becker, produzindo já alguns deslizamentos.

Essa adesão nos situava no campo da memória discursiva. Há memória porque há retomada e regularização de sentidos, porque há um regime de repetibilidade, diria Indursky 
(2011). A Gramática de Nascentes foi o discurso fundador da gramatização brasileira do espanhol, o primeiro contorno dado à língua em um instrumento linguístico produzido no Brasil. Um tecido de noções formuladas por Courtine - “domínio de memória”, de “atualidade” e de “antecipação” (2009, p. 110-114) - nos permitiu pensar a obra de Nascentes como "domínio de atualidade”, um objeto que retoma discursos do passado e, ao mesmo tempo se projeta ao futuro. Uma dobradiça que num primeiro movimento, nos levou a buscar no passado, no “domínio de memória”, traços de discursos que se sustentam em funcionamentos anteriores, traços desse "sempre já do discurso" e "dos sentidos” (Courtine, 2009; Indursky, 2011). Nesse giro ao passado, pudemos identifica os discursos da RAE e dos instrumentos linguísticos produzidos por ela como imaginários fundadores e propagadores das ideias disciplinadoras sobre a língua ou, seguindo Courtine (ibid. p. 112), identificá-los como "formulações-origem" 236 . Se como apresentamos no percurso da tese, a força desse imaginário de “unidade” e “purismo” linguístico marcou os debates, as disputas e a produção de instrumentos linguísticos elaborados nas jovens repúblicas que se libertaram da Espanha no decorrer do século XIX, também é verdade que esse imaginário marcou a obra de Nascentes. Não poderia ter sido diferente, aquelas produções tinham sido as fontes utilizadas por ele. As Repúblicas hispano-americanas se tornaram independentes politicamente, mas, embora não de forma hegemônica, a produção de instrumentos linguísticos retomava, regularizava e repetia os sentidos de "unidade” e "purismo". Sentidos esses também retomados, regularizados e repetidos por Nascentes na produção da Gramática, na qual reverberam os discursos da Academia.

Mas a repetição de sentidos também pode levar a efeitos de redefinição, de transformações e deslizamentos. Esses últimos identificados na Gramática naqueles espaços que acima designamos como de tímidos afastamentos desse imaginário fundador de uma memória sobre a língua ou, inclusive, de suaves deslizamentos, como por exemplo, na abordagem que Nascentes faz da noção de "barbarismos", retomando da Gramática da RAE de 1917, mas redefinindo, por meio de um procedimento de modalização, os aspectos mais prescritivos.

Nas repetições havia uma hegemonia da matriz de sentidos, mas havia também fissuras por onde emergiam outros sentidos das ideias linguísticas do autor. Nascentes produziu sua vasta obra como filólogo, lexicógrafo e gramático a partir de um lugar

\footnotetext{
${ }^{236} \mathrm{O}$ autor esclarece que "o domínio das formulações-origem não atribui, de modo algum, um `começo' ao processo discursivo, mas constitui o lugar onde se pode determinar, no desenvolvimento do processo discursivo, o surgimento de enunciados que figuram como elementos do saber próprio de uma FD” (ibid., p. 112).
} 
particular nesse contexto social e geográfico específicos: o de ser negro numa sociedade que nos anos 1920 falava fortemente em branqueamento racial e, assim, na desaparição próxima de negros e mulatos. Era um autor que parecia concentrar na sua pessoa as próprias tensões da sociedade da época. Um autor que se formou em meio aos debates e disputas sobre a língua portuguesa em território brasileiro, entre os que defendiam o purismo das formas lusitanas e os que propunham uma ruptura. O estudo de parte de sua ampla obra nos permitiu compreender não só a percepção das claras diferenças que o autor observava entre o português de Portugal e do Brasil, embora entendendo que era errado pensar que as línguas eram duas, mas também a concepção histórica, social e política dos processos linguísticos e das transformações sofridas, especialmente pelas línguas “transplantadas”. Lembremos a relação que pudemos inferir entre emancipação e liberdade da língua, recuperando uma passagem de O Linguajar Carioca: "submeter o nosso falar diferente às formas portuguesas é um absurdo desprezível e servilmente colonial” (Nascentes, 1922, p. 12). Essas eram também as ideias que o atravessavam e o faziam sujeito do discurso, por isso, não é difícil compreender que surgissem na produção da Gramática de espanhol para uso dos brasileiros, mesmo nas margens, e nas estreitas fissuras de uma matriz de sentidos (colonial) mais hegemônica, certos deslizes que, como suaves pinceladas referiam-se à diversidade da língua e às controvérsias que a habitam.

A Gramática foi o primeiro instrumento linguístico produzido para o ensino de espanhol na escola e o único (provavelmente) que circulou até os anos 1940 quando se multiplica, de forma acelerada, a produção editorial. Ao pensar a obra como dobradiça, outro movimento a projeta ao futuro, a esse período posterior da gramatização da língua, o da Era Vargas, no qual o conjunto de gramáticas e manuais decorrente da rápida multiplicação da produção constitui um “domínio de antecipação”. Ou em outras palavras, materialidades nas quais ressoam certas formulações da Gramática de Nascentes - e, consequentemente, dos discursos da Academia - que estabelecem relações com esse conjunto.

Nesse novo período pesquisado, os discursos do Estado eram potentes, projetava-se uma formação integral e humanista dos adolescentes e, nesse contexto, projetava-se também outro lugar para o espanhol e outros sentidos para o ensino da língua. O Programa da disciplina, formulado a partir do Ministério de Educação e Saúde, concentrava essa mudança de paradigma. Foi um discurso inovador com relação ao dos anos 1920, que tinha se restrito ao aspecto gramatical. Propunha-se abordar a dimensão 
oral e escrita da língua, a história da literatura espanhola e hispano-americana e, a partir de leituras breves, a vida e as paisagens dos países que compõem esses espaços geográficos. Como gênero discursivo, a gramática já não dava conta dessas exigências, no entanto, as transformações foram mais demoradas que a determinação oficial para que se executara um programa de ensino. Assim, especialmente nos primeiros anos posteriores à determinação da obrigatoriedade da língua no currículo do ensino médio, as gramáticas continuaram sendo os principais suportes para o trabalho escolar.

A produção editorial tinha que se transformar, as determinações históricas dos processos de produção de sentido instauravam e "exigiam” mudanças, e alguns anos depois vemos o surgimento - no âmbito de ensino da língua espanhola no Brasil - de um novo gênero discursivo, o manual, respondendo assim à complexificação dessa prática no âmbito escolar.

Do conjunto de instrumentos linguísticos estudados, selecionamos para uma análise mais aprofundada o Manual de espanhol (1945), de Idel Becker. Os motivos foram diversos: (i) foi uma das obras de maior circulação em toda a história do ensino da língua, (ii) a sua primeira versão, ainda como gramática e com um viés altamente enciclopedista, exigia um estudo aprofundado pelo modo em que eram abordadas as questões linguísticas e a história das literaturas, (iii) o autor, assim como Nascentes, parecia condensar na sua própria biografia questões de época (a sua circulação entre Argentina e Brasil, desenvolvendo sua vida no âmbito dessas duas culturas e dessas duas línguas e, especialmente, os “anseios pessoais de fraternidade latino-americana”) e, não menos importante, entender que (iv) as reformulações realizadas pelo autor se configuravam como materialidades potentes para o estudo das transformações das condições de produção. Três versões em três momentos históricos diferentes (os dois primeiros muito próximos) que produzem, como efeito, mudanças significativas na materialidade e na composição dessa obra que se reeditou até meados dos anos 1990.

Para finalizarmos este primeiro momento, vale a pena fazermos algumas considerações sobre essa experiência de análise que buscou identificar o que permanecia e o que mudava em cada uma das versões, em estreita relação com as transformações das condições de produção. As materialidades das três versões da obras, per se, não explicavam as transformações identificadas. Apenas podíamos reconhecêlas. Foi o estudo desse complexo emaranhado social, educativo e político o que nos permitiu lançar possíveis explicações/interpretações para as operações de reformulação produzidas pelo autor. 
As mudanças nos subtítulos das capas, a língua utilizada na elaboração da obra, a sua extensão e a passagem da gramática para o manual foram as primeiras pistas. De modo geral, as transformações entre a primeira e a segunda versão revelam um trabalho político de autoria na direção de melhor atender as diretrizes ministeriais e a demanda decorrente da ampliação do ensino. Essa segunda versão, de 1947, foi a que de forma mais equilibrada conseguiu atender a expansão dos sentidos propostos desde o Ministério para o ensino da língua. Já estamos diante de um manual organizado em lições regulares que abordam a vida e a paisagem do mundo hispânico, distribuindo de forma equilibrada as lições que se ocupavam da Espanha e as que se referiam aos países da América hispânica. Como solicitava o Programa, essas lições têm uma leitura inicial que nos conecta com vidas e paisagens diversas de países diferentes e as perguntas sobre elas abrem, entendemos, para práticas orais da língua, também exigidas, além de para reflexões culturais, linguísticas e literárias. Essas lições também incluem um provérbio que permite vislumbrar a projeção dessa formação mais integral e patriótica dos estudantes que o governo propunha e, além disso, encontramos tópicos para o estudo da gramática da língua e exercícios para as respectivas práticas.

O reconhecimento das operações discursivas que marcaram as reformulações omissões, agregados, substituições e deslizamentos - e das representações que operaram (a projeção de estudantes e docentes, a realidade escolar, as diretrizes ministeriais, os novos métodos, dentre outros) nos levaram a identificar essa segunda versão, tanto na sua composição como na abordagem das questões linguísticas e culturais, como a mais alinhada com o projeto político-educativo da Era Vargas, embora Getúlio já não estivesse no poder. Tinham passado dois anos do lançamento da primeira e o tempo necessário para que as transformações ocorressem. Esse alinhamento às diretrizes governamentais e a adequação à realidade escolar e a um mercado do livro, também implicaram em renúncias. Com a omissão das notas explicativas da primeira versão, desaparecem os esclarecimentos sobre "pontos de vista” do autor, as tomadas de posição relacionadas à sua experiência docente, as reflexões mais aprofundadas sobre a língua e sua história e as controvérsias entre discursos desse imaginário fundador (as formulaçõesorigem) da RAE e seus instrumentos linguísticos, e a mirada do autor para a diversidade da língua que por vezes se contrapunha "às severas opiniões da Academia”. Embora omitidas, elas ressoam - modalizadas - ao longo da obra. Se as controvérsias se suavizam - desaparecendo por vezes -, os espaços que abordam aspectos da diversidade da língua permanecem. Com relação à Gramática de Nascentes, a obra de Becker produz uma 
maior erosão desse imaginário fundador da Academia. Um lento trabalho que verá continuidade várias décadas depois, com a produção de obras afetadas já pela produção do conhecimento provinda das universidades brasileiras e da região ${ }^{237}$. E se essa erosão nos permite assinalar transformações na realização das duas obras (a de Nascentes e a de Becker), também é verdade que houve permanências, no sentido de regularidades que continuaram. Dentre ela, uma parece fundamental: a percepção que ambos os autores tiveram sobre as particularidades desse par linguístico e sobre a necessidade para que a proximidade contida nessas "semelhanças/diferenças" fosse levada em conta no processo de ensinoaprendizado dessa língua tão “singularmente estrangeira” (Celada, 2002).

A realidade educativa geral e a das línguas estrangeiras de forma particular para os interesses deste trabalho mudaram significativamente em 1961 com a Lei de Diretrizes e Bases, segundo a qual as línguas clássicas e as estrangeiras deixavam de fazer parte do currículo obrigatório. Por tanto, a circulação da língua seria outra e o número de alunos também. Sobre a última versão (posterior a essa data), agora sem exigências do Estado a serem atendidas, vale lembrar que o equilíbrio se quebra, que América hispânica fica silenciada, assim como as controvérsias sobre a língua. No entanto, em menor grau, a diversidade continua sendo apresentada. Estamos diante de uma obra mais afetada pelas regras do mercado, um viés que marcará também a próxima aceleração na produção e circulação de instrumentos linguísticos, ocorrida a partir dos anos 1990.

II.

As reflexões desenvolvidas neste último item, embora parcialmente referidas a outro momento histórico, permitirão compreender indagações que atravessam esta tese. Se a Lei de Diretrizes e Bases de 1961 é um acontecimento político-educativo especialmente significativo para compreendermos a última reformulação do Manual de Espanhol, também é chave para voltarmos sobre um dos núcleos disparadores da pesquisa: as indagações sobre o não “enraizamento” do espanhol na escola. Para tanto, voltemos aos anos prévios à LDB, à presidência de Juscelino Kubitschek (1956-1961).

\footnotetext{
${ }^{237}$ De forma mais ampla, essa produção de conhecimento foi fundamentalmente afetada pelas políticas linguísticas que surgiram como efeito de décadas de lutas anti-colonialistas.
} 
Os dois períodos estudados nos mostraram que os anseios políticos de um Estado com relação às línguas estrangeiras têm um alto grau de determinação nas ações que administram e organizam o currículo linguístico da escola. Também nos mostraram as relações de força ao interior do Estado. Lembremos que durante o Estado Novo, as decisões não eram submetidas às disputas legislativas, sempre espaço de tensões políticas. O Congresso havia sido desativado e os anseios do governo com relação à inclusão da língua espanhola seguiram seu curso. Esse é um aspecto fundamental na compreensão de acontecimentos posteriores com relação à língua espanhola, que ocorreram durante a presidência de Juscelino Kubitschek (JK). À diferença de Vargas, Juscelino assume a presidência de forma democrática e em outro momento do mundo e do país. A Guerra tinha terminado ${ }^{238}$ e o entorno democrático dava plenos poderes ao poder Legislativo ${ }^{239}$, isso exigia do governo a negociação de decisões, não só dentro do poder público, mas também com grupos ligados ao capital internacional, tendo que administrar as pressões internas e as disputas de força.

Durante o governo JK, o Poder Executivo apresenta à Câmara dos Deputados o que, do nosso ponto de vista, foi o projeto mais ousado na história do Brasil com relação ao ensino da língua espanhola: o 4.606. Um projeto que alterava o Decreto-Lei 4.244, de 9 de abril de 1942 - analisado na tese -, dando a ele uma continuidade ampliada. Em mensagem pronunciada no Congresso, em 1958, o presidente propunha equiparar o ensino de espanhol ao de inglês [e francês] ${ }^{240}$ em número de horas e em anos de ensino. Após o discurso, o projeto teve repercussão na prensa local. Três jornais diferentes publicaram matérias que difundiam e comentavam, com sentidos eufóricos, o pronunciamento do presidente com relação ao espanhol ${ }^{241}$. Embora arquivado após anos de tramitação (1971) (Rodrigues, 2010), parece um momento chave para entendermos os

\footnotetext{
${ }^{238}$ Após as conferências de Yalta (1945) e com o início da Guerra Fria se produz a repartição das zonas de influência entre o leste e o oeste e as consequentes áreas de influencia idiomáticas que tinham se configurado naqueles anos e que estavam em vigência durante a presidência de Kubitschek. Pensamos especialmente na importância da área de influência do inglês.

${ }^{239}$ No âmbito educativo o governo teve que enfrentar o conservadorismo católico, especialmente contrário ao projeto Novacap que tinha o planejamento do futuro educacional do país e a fundação de um conjunto de escolas públicas que iam da educação infantil ao ensino médio (Montalvão, 2013). Como afirma o historiador, em maio de 1957, o projeto da Lei de Diretrizes e Bases ganhou notoriedade devido à polarização das posições dos deputados (ibid.). Montalvão assinala ainda que o ano de 1958 foi pródigo em uma produção textual católica que reafirmava a liberdade de ensino que não podia perder de vista a tradição cristã.

${ }^{240} \mathrm{O}$ projeto oscila nas formulações se referindo ora unicamente ao inglês, ora ao inglês e francês.

${ }^{241}$ Os jornais e as matérias recuperadas em pesquisa na Biblioteca Nacional (Rio de Janeiro) são os seguintes: O Globo, 25 de setembro de 1958, "Ensino de espanhol ajudará a Operação Panamericana”; Jornal do Brasil, 26 de setembro de 1958, "Operação Panamericana também no setor cultural”; Última Hora, 30 de setembro de 1958, "Espanhol obrigatório no Ginásio para fortalecer a amizade interamericana”. Chegamos a esse arquivo graças ao trabalho de Ayllón (2004) e trabalharemos sobre ele em outra oportunidade.
} 
confrontos políticos que atravessam os debates sobre as línguas. A Comissão de Educação da Câmara tinha opinado a favor do arquivamento do projeto já em $1959^{242}$. E a própria aprovação da LDB, em 1961, que retira do currículo de disciplinas obrigatórias as línguas estrangeiras modernas (e as clássicas) inviabilizou a continuidade da proposta.

Em 1959, ano em que se propõe o arquivamento do projeto, entram em funcionamento nove sedes dos Institutos de Cultura Hispânica, vinculados ao Estado espanhol (Ayllón, 2004). Interpretamos essas ações à luz das conjunturas históricas, especialmente, do impulso dado à língua espanhola pelo poder executivo e da reaproximação com o governo da Espanha, gestos que parecem ter favorecido diretamente a política de expansão cultural desse país na América Latina (ibid.) ${ }^{243}$. Os Institutos de Cultura Hispânica começaram a oferecer cursos de espanhol para a população e tiveram uma importância particular, especialmente a partir de 1961, quando a Lei de Diretrizes e Bases exclui as línguas estrangeiras da grade de disciplinas obrigatórias do ensino médio. Com essa medida, embora não se possa afirmar que o espanhol desaparece efetivamente da escola, sim o faz dos discursos e da política linguística explícita do Estado. Nessa conjuntura, essas instituições espanholas instaladas no Rio de Janeiro se transformaram em uma referência para o aprendizado da língua ${ }^{244}$.

Voltando ao projeto, entendemos que deve ser compreendido em estreita relação com os princípios da política exterior do governo: a Operação Pan-Americana, que como condições de produção nos permite observar a relação de aproximação dos países do hemisfério sul com a política continental. Vejamos o último parágrafo da mensagem do presidente da República, encaminhada juntamente com a Exposição de Motivos do Ministério de Educação e Cultura ao $1^{\circ}$ secretário da Câmara de Deputados, José Bonifácio, em 22 de setembro de 1958:

Em verdade, [o projeto] é uma resultante inafastável das amplas perspectivas que se abriram ao entrelaçamento das relações pan-americanas, através da atual política continental, de mais íntima aproximação dos países deste hemisfério (itálico nosso).

Já na Exposição de Motivos afirmava-se o seguinte:

\footnotetext{
${ }^{242}$ Essa informação está no Dossiê 4606/1958 da Câmara de Deputados.

243 Após a viagem de Kubitschek à Espanha, em 1956, houve uma reaproximação internacional com o governo desse país. As relações tinham sido interrompidas durante a segunda guerra por causa do isolamento e como parte do cerco diplomático internacional a Franco (Ayllón, 2004). Embora no momento da viagem Franco fosse ainda o presidente espanhol, Juscelino identifica no país europeu um sócio potencial que podia cooperar com o Brasil no seu programa de desenvolvimento.

${ }^{244}$ Em um trabalho apresentado no "I Congreso de Instituciones Hispánicas”, Navarro Morales e Pôrto (1963, p. 330) afirmam que os Institutos "no han cesado de crecer” e "ya cuentan con un número de alumnos equivalente al total de los estudiantes de español de las secciones de Letras de las cuatro Facultades de Filosofía de Río”.
} 
O maior estreitamento dos povos do continente americano reclama um estudo mais intenso do espanhol no curso secundário e a sua inclusão como disciplina obrigatória no primeiro ciclo, a fim de ser dada maior difusão ao seu ensino e tornar possível a plena consecução dos seus objetivos.

Após a leitura dos documentos surge a seguinte indagação: a ampliação dos anos de ensino e a obrigatoriedade da língua nesses anos, equiparando-a ao francês e ao inglês, teriam funcionado finalmente a favor de uma maior estabilização do espanhol na escola? Se a pergunta evidentemente não pode ser respondida (embora nos inclinemos pela afirmativa), sim nos permite pensar esse projeto de lei como lugar de memória sobre o espanhol no sistema educativo e sobre a importância que as relações internacionais e as disputas entre diversos grupos do poder tiveram (e terão) na construção dessa memória.

Sem dúvida, após o arquivamento do projeto e com a aprovação da LDB de 1961 houve uma mudança de rumo para o espanhol. Se as formulações do período Vargas reforçaram com a obrigatoriedade a importância da língua para o projeto político do governo (com relação às ações mais tênues dos anos 1920), desta vez, os anseios do Estado (expressos por meio do poder executivo) tinham sido derrotados nessas disputas de força ao interior do Legislativo. Do complexo de formações discursivas, outra era a dominante (Pêcheux, [1975] 2009) e os sentidos do período anterior tinham sido refutados. Essa “derrota” também constrói uma memória a partir de outra matriz de sentidos, antagônica àquela que, de diversos modos e intensidades, levou a língua para o interior do âmbito escolar, apostando na importância do seu ensino para "uma maior e melhor relação com os países vizinhos”. Essa “derrota” faz surgir outras redes de memória, que se inscrevem em sentidos de uma formação discursiva a partir da qual a língua espanhola é novamente abafada nas suas potencialidades e importância e a partir da qual podemos compreender dois acontecimentos ocorridos mais recentemente: por um lado, a Reforma do Ensino Médio que começou com a medida provisória 746, de setembro de $2016^{245}$, uma das primeiras medidas do governo que assume após o golpe contra Dilma Roussef e que, dentre outras alterações estruturais, propõe a retirada da grade curricular da língua espanhola, incluída de forma facultativa em 2005. E, por outro, também uma das primeiras medidas do Ministro das Relações Exteriores do governo Bolsonaro, Ernesto Araújo (fevereiro de 2019), que foi excluir o curso sobre a

\footnotetext{
${ }^{245}$ Em fevereiro de 2017, a medida provisória acabou virando a Lei 13.415. Nela se propõe o estudo obrigatório apenas da língua inglesa no ensino médio - e outras línguas estrangeiras optativas - e o inglês como única língua obrigatória a ser estudada no ensino fundamental, do $6^{\circ}$ ao $9^{\circ}$ ano.
} 
história dos países da América Latina do currículo do Instituto Rio Branco, a escola de formação de diplomatas do Itamaraty ${ }^{246}$. Vemos ao longo da história e do estudo desses lugares de memória de ordem diversas, as oscilações e alternâncias da matriz de sentidos que vai afetando a presença/ausência do espanhol no sistema educativo e as diferentes tramas políticas que dão maior visibilidade/invisibilidade à língua nesse âmbito e importâncias diferentes às relações com os países vizinhos.

Enquanto os discursos jurídico/legislativos dos anos 1920 de forma tênue (decreto lei $\mathrm{N}^{0}$ 3.674), da Era Vargas com maior intensidade (Lei $\mathrm{N}^{\circ} 4.244$ ), do projeto de Juscelino Kubitschek de 1958 que ampliava a proposta dos vinte anos anteriores (Projeto de Lei $\mathrm{N}^{\mathrm{0}}$ 4.606) e do governo Lula sem a força que se esperava pela conjuntura política do momento (Lei $\mathrm{N}^{\circ}$ 11.161), se inscrevem numa formação discursiva a partir da qual se projeta a importância da língua na escola, mesmo que de modos diversos; a derrota do projeto em 1958, a aprovação da LDB de 1961 e a exclusão da língua pela lei 13.415 durante o governo Temer produzem um discurso que, deixando o inglês numa posição central (também de modos diversos), refutam os sentidos políticos do estudo da língua para uma vinculação mais efetiva com os países vizinhos.

Os deslocamentos ao interior da primeira série nos levam a uma última reflexão ${ }^{247}$. Se considerarmos que essa série remete a uma mesma formação discursiva cujos sentidos dão visibilidade ao espanhol, incluindo de diversos modos a língua no sistema educativo, devemos compreender que os enunciados diferentes que a integram foram produzidos a partir de posições-sujeito diversas e que, desse modo, esses enunciados se relacionam diferentemente com a ideologia, produzindo efeitos de sentidos diversos. Do mesmo modo, nessa última análise realizada, deveríamos pensar como se posicionam nessas duas séries a LDB de $1971^{248}$ e a de $1996^{249}$, não focalizadas aqui.

Entendemos que em meio a outras problemáticas, o trabalho abordou no percurso esses sentidos diversos, mas, sem dúvida, aprofundamentos futuros poderão contribuir para ajustar a movência dos sentidos e a oscilante e sempre política construção de uma memória discursiva sobre o espanhol no Brasil.

\footnotetext{
${ }^{246}$ A reformulação que envolveu a extinção dessa disciplina sinaliza uma menor ênfase a temas da região. Para mais detalhes, ver nota publicada pela Folha de São Paulo no seguinte link: www1.folha.uol.com.br/mundo/2019/02/chanceler-exclui-curso-sobre-america-latina-de-formacao-dediplomatas.shtml

${ }^{247}$ Fazemos essa reflexão a partir do trabalho teórico-analítico de Indursky (2011).

${ }^{248}$ As línguas estrangeiras voltam a fazer parte do currículo obrigatório como opção das disciplinas a serem escolhidas pelos Conselhos Estaduais de Educação. Para uma maior compreensão ver Rodrigues (2012, p. 90-93).

${ }^{249}$ Para compreender a complexidade e os novos sintagmas que emergem nessa LDB com relação às línguas estrangeiras, ver Rodrigues (ibid., p. 96-100).
} 


\section{BIBLIOGRAFIA}


AL ASSAL, Marianna Boghosian. Arquitetura e Identidade Nacional no estado Novo. As escolas práticas de agricultura no Estado de São Paulo. São Paulo: Annablume, FAPESP, 2013.

ALONSO, Amado. Castellano, español, idioma nacional. Historia espiritual de tres nombres. Buenos Aires: Editorial Losada S.A, [1943] 1979.

ALVARADO, Maite. Paratexto. Enciclopedia semiológica. Buenos Aires: Eudeba, 2009.

ALVES, Therezinha Nascentes. Fala de Therezinha Nascentes Alves. In: Cadernos do X Congresso Nacional de Linguística e Filologia, Volume X, $\mathrm{n}^{0 .} 17,2006$. Disponível em: http://www.filologia.org.br/xcnlf/17/01.htm. Acesso em: 26 de agosto de 2017.

ALVIM, Zuleika. Imigrantes: a vida privada dos pobres do campo. In: Nicolau Sevcenko (org.), História da Vida Privada no Brasil 3. República: da Belle Époque à Era do Radio. São Paulo: Companhia das Letras, 1998.

ARNOUX, Elvira Narvaja de. El discurso normativo en los textos gramaticales de Andrés Bello. In: — BEIN, Roberto (copiladores), Prácticas y representaciones del lenguaje. Buenos Aires: Editora Universitaria de Buenos Aires, 1999, pp. 37-61.

La Glotopolítica: transformaciones de un campo disciplinario. In: Lenguajes: teorías y prácticas. Gobierno de la Ciudad de Buenos Aires, Instituto Superior del Profesorado, 2000.

Análisis del discurso. Modos de abordar materiales de archivo. Buenos Aires: Santiago Arcos Editor, 2006.

El discurso sobre la nación y el lenguaje en la formación del Estado (Chile, 1842-1862). Estudio glotopolítico. Buenos Aires: Santiago Arcos editor, 2008.

Representaciones sociolingüísticas y construcción de identidades colectivas en el Mercosur. In: CELADA, Maite; FANJUL, Adrián; NOTHSTEIN, Susana (coordinadores), Lenguas en un espacio de integración: acontecimientos, acciones, representaciones. Buenos Aires: Biblos, 2010.

Desde Iguazú: mirada glotopolítica sobre la integración regional. In: FANJUL, Adrián; CASTELA, Greice da Silva (orgs.). Línguas, políticas e ensino na integración regional. Cascavel: Assoeste, 2011, pp. 38-64.

Hacia una gramática castellana para la escuela secundaria: opciones y desplazamientos a mediados del siglo XIX. In: Boletín de Filología, Tomo XLIX, número 2. Universidad de Chile, 2014, pp. 19-48. 
La Perspectiva Glotopolítica en el Estudio de los Instrumentos Lingüísticos: aspectos teóricos y metodológicos. In: Matraga, Rio de Janeiro, v. 23, n. 38, jan/jun 2016, pp. 18-42.

. El tratamiento de la diferencia lingüística en las gramáticas para la escuela secundaria argentina de fines del siglo XIX y comienzos del XX. Boletín de la Sociedad Española de Historiografía Lingüística (BSEHL), n. 11, 2017, pp. 31-53.

; BEIN, Roberto. Hacia una historización de las políticas de enseñanza de lenguas. In: (org.) Política lingüística y enseñanza de lenguas. Ciudad Autónoma de Buenos Aires: Biblos, 2015, pp. 13-50.

; DEL VALLE, José. Las representaciones ideológicas del lenguaje. Discurso glotopolítico y panhispanismo. In: Spanish in context, número especial sobre “Ideologías lingüísticas”, John Benjamins Publishing Company, 2010, pp. 1-24.

; DEL VALLE. Introducción a la creación del español: perspectivas latinoamericanas y transatlánticas. In: DEL VALLE, J. (ed.) Historia política del español. La creación de una lengua. Madrid: Aluvión editorial, 2015 (1 $1^{\text {a }}$ versão em espanhol), pp. 145-156.

; NOTHSTEIN, S. Introducción. Glotopolítica, integración regional sudamericana y panhispanismo. In:____ (eds.), Temas de Glotopolítica. Integración regional sudamericana y panhispanismo. Ciudad Autónoma de Buenos Aires: Biblos, 2014, pp. 9-29.

ASENCIO, José J. Gómez. De “gramática para americanos” a "gramática de todos”. El caso de Bello (1847). In: Revista argentina de historiografía lingüística. I, 1, 2009, pp. 1-18.

ASENCIO, Pilar. Una frontera sociolingüística en el Uruguay del siglo XIX: lengua española e identidad nacional. In: Spanish in context. ISSN: 1571 - 0726. 1, 2, 2004, pp. 215-240.

AUROUX, Sylvain (1992). A revolução tecnológica da gramatização. Trad. Eni Orlandi $-2^{\mathrm{a}}$ ed. Campinas, SP: Editora da Unicamp, 2009a.

. Filosofia da Linguagem. São Paulo: Parábola, 2009b.

AUTHIER-REVUZ, Jacqueline. (2012). Heterogeneidade(s) Enunciativa(s). In: Cadernos De Estudos Lingüísticos, 19, Campinas, jul/dez 1990, pp. 25-42.

AYLLÓN PINO, Bruno. Las relaciones entre Brasil y España ponderadas desde la perspectiva de la política exterior brasileña, (1979 - 2000). Tese de doutorado apresentada no Departamento de Direito Público Internacional e Relaciones Internacionais da Universidade Complutense de Madrid, 2004.

BAGGIO, Kátia Gerab. A “outra” América: A América Latina na visão dos intelectuais brasileiros das primeiras décadas da república. Tese de doutorado. São Paulo: Depto. de História - FFLCH - USP, 1998. 
BAGNO, Marcos. O que é uma língua? Imaginário, ciência \& hipóstase. In: LAGARES, Xoán Carlos; BAGNO, Marcos (orgs.): Políticas da Norma e conflitos linguísticos. São Paulo: Parábola Editorial, 2011, pp. 355-387.

BAKHTIN, Mikhail. Estética da criação verbal. São Paulo: Martins Fontes, 1997.

BALDINI, Lauro. A Nomenclatura Gramatical Brasileira interpretada, definida, comentada e exemplificada. Dissertação de mestrado, IEL, Unicamp, Campinas, 1999.

; A NGB e o dicionário de Mattoso Câmara: duas formas de dizer. In: Revista Brasileira de Letras (3/4). São Carlos: Editora da UFSCar, 2002, pp. 57-65

BARROS, C; COSTA, E.; GALVÃO, J (org.). Dez anos da "Lei do Espanhol” (20052015). Belo Horizonte: UFMG, 2016.

BECHARA, Evanildo. Antenor Nascentes - Romanista. In: Revista Brasileira de Filologia, $1^{\circ}$ semestre, 2014.

BENCHIMOL, Jaime Larry. Pereira Passos: um Haussmann tropical. A renovação urbana do Rio de Janeiro no início do século XX. Rio de Janeiro: Secretaria Municipal de Cultura, Turismo e Esportes, Departamento Geral de Documentação e Informação Cultural, Divisão de editoração - Biblioteca Carioca, 1992.

BENEDETTI, Mario. RODÓ, José Enrique. In: Oreggioni, Alberto: Nuevo Diccionario de Literatura Uruguaya L-Z. Ediciones de la Banda Oriental, Uruguay, 2001

BENTIVEGNA, Diego. Estudio Preliminar. In: GRAMSCI, Antonio. Escritos sobre el Lenguaje. Sáenz Peña: Universidad Nacional de Tres de Febrero, provincia de Buenos Aires, 2013.

La eficacia literaria: configuraciones discursivas de literatura nacional en manuales argentinos 1866-1947. Ciudad Autónoma de Buenos Aires: Eudeba, 2017.

BLANCO, María Imelda. La configuración de la "lengua nacional” en los orígenes de la escuela secundaria argentina. In: ARNOUX, Elvira Narvaja de, BEIN, Roberto (compiladores): Prácticas y representaciones del lenguaje, Buenos Aires, Editora Universitaria de Buenos Aires (EUDEBA), 1999, pp. 75-100.

BLOCH, Pedro. Entrevista a Antenor Nascentes. In: Cadernos do X Congresso Nacional de Linguística e Filologia, Volume $\mathrm{X}, \mathrm{n}^{\mathrm{0}}$ 17, 2006. Disponível em: http://www.filologia.org.br/xcnlf/17/08.htm. Acesso em: 18 de setembro de 2017.

BOLOGNESI, Luiz. A Revolução de 1930. In: Documentário Guerras do Brasil.doc. $1^{a}$ temporada, episódio 4, 2018.

BOURDIEU, Pierre; WACQUANT, Loïc. Sobre as artimanhas da razão imperialista. In: Estudos Afro-Asiáticos, Ano 24, nº 1, 2002, pp. 15-33.

BRAUDEL, Fernand. O mediterrâneo: o espaço e a história. Lisboa: Teorema, 1987. 
BUENO, Clodoaldo. O Barão do Rio Branco no Itamaraty (1902-1912). Revista Brasileira de política internacional, vol. 55 n² 2. Brasília, jul/dec. 2012.

CÂMARA JR, Joaquim Mattoso. Dispersos. Rio de Janeiro: Fundação Getúlio Vargas, Antenor Nascentes e a Filologia Brasileira, 1972. In: Revista Brasileira de Filologia, $1^{\circ}$ semestre, 2014, pp. 191-195.

CAMPOS, Cynthia Machado. A política da língua na Era Vargas: proibição do falar alemão e resistências no Sul do Brasil. Campinas, SP: Editora da UNICAMP, 2006.

CANDIDO, Antonio. Os brasileiros e a nossa América. In: Recortes, Rio de Janeiro: Ouro sobre Azul, 2004, pp. 143-155.

A Revolução de 1930 e a Cultura. In: A educação pela noite.

Rio de Janeiro: Ouro sobre Azul, 2011.

CÁNOVAS, Maria Dalva Klaumann. Inmigrantes espanhóis na Paulicéia: trabalho e sociabilidade urbana, 1890-1922. Tese apresentada ao Programa de Pós-Graduação em História Social, USP, 2007.

CAPELATO, Maria Helena. O “Gigante brasileiro" na América Latina: ser ou não ser latino-americano. In: MOTA, Guilherme (org.) Viagem incompleta. A experiência brasileira (1500-2000). Editora SENAC: São Paulo, 2000, pp. 285-316.

Cuadernos Hispanoamericanos - ideias políticas numa revista de cultura. In: Varia Historia, vol. 21, No 34, Belo Horizonte, julho/2005.

CARVALHO, José Murilo de. Os bestializados: o Rio de Janeiro e a República que não foi. São Paulo: Companhia das Letras, 1987.

CARVALHO, Maria Alice Rezende de. Rio de Janeiro - Crepúsculo da Ouvidor. In: GORELIK, Adrián; PEIXOTO, Fernanda (orgs.). Cidades sul-americanas como arenas culturais, São Paulo: Edições SESC São Paulo, 2019, pp. 25-36.

CELADA, María Teresa. O espanhol para o brasileiro: uma língua singularmente estrangeira. Tese de doutorado, IEL, Unicamp, Campinas, 2002.

- Problemáticas impuestas por el SIELE. Brasil, panhispanismo y un oportuno "iberoamericanismo". Conferência oferecida no X Coloquio CELU, Universidade Nacional de Rio Cuarto, Córdoba, Argentina, 2019.

CERVO, Amado Luiz. Relações Internacionais da América Latina: velhos e novos paradigmas. Brasília: Instituto Brasileiro de Relações Internacionais (IBRI), 2001.

, RAPOPORT, Mario (orgs.). História do Cone Sul. Rio de Janeiro: Revan, Brasilia: Editora Universidade de Brasilia, 1998.

CIFUENTES, B. La política lexicográfica de la Academia Mexicana de la Lengua a finales del siglo XIX. In: Del Valle, J. (ed.) Historia política del español. La creación de una lengua, Madrid: Aluvión editorial, 2015 (1ª versão em espanhol), pp. 194-209. 
CONDURU, Guilherme Frazão. O subsistema Americano, Rio Branco e o ABC. Rev. Bras. Polít. Int. 41 (2), 1998, pp. 59-82.

COURTINE, Jean-Jacques (1981). Análise do discurso político: o discurso comunista endereçado aos cristãos. São Carlos: EDUFSCAR, 2009.

CUNHA, Celso. Presença de Antenor Nascentes. In: NETO, Barbadinho (org.), Estudos Filológicos. Volume dedicado à memória de Antenor Nascentes. Rios de Janeiro, 2003.

DALLABRIDA, Norberto. A Reforma Francisco Campos e a modernização nacionalizada do ensino secundário. In: Educação, Porto Alegre, v. 32, n. 2, maio/agosto 2009, pp. 185-191.

DALPONTE, B., MARINKEFF, C. La relevancia estratégica del vínculo ABC en la política exterior argentina. Trabalho apresentado na "Jornada de Relaciones Internacionales de FLACSO”, outubro de 2009.

DANNA, Stela Maris Detregiacchi Gabriel. A língua espanhola no Brasil: História de sua presença em materiais linguísticos produzidos entre 1919 e 1961. Tese (doutorado em Linguística) - Faculdade de Filosofia, Letras e Ciências Humanas, Universidade de São Paulo, São Paulo, 2019.

DEL VALLE, José. La historificación de la lingüística histórica. Los orígenes de Ramón Menéndez Pidal. In: Historiographia Lingüística XXIV. John Benjamin, Amsterdam, 1997, pp. 175-196.

- Lenguas imaginadas: Menéndez Pidal, la lingüística hispánica y la configuración del estándar. In: Bulletin of Hispanic Studies, 1999, pp. 215-233.

. (ed.). Lenguas nacionales y multinacionales: las políticas de promoción del español en Brasil. Revista da Abralin, vol. 4, nº 1 e 2, 2005, pp. 197-230.

La lengua, ¿patria común? Ideas e ideologías del español. MadridFrankfurt: Vervuert-Iberoamericana, 2007.

. Lenguaje, política e historia: ensayo introductorio (Parte I. Fundamentos teóricos). In: Del Valle, J. (ed.) Historia política del español. La creación de una lengua. Madrid: Aluvión editorial, 2015 (1 $1^{\text {a }}$ versão em espanhol), pp. 3-26.

DEZERTO, Felipe Barbosa. Francês e Colégio Pedro II: um processo de construção de um campo disciplinar escolar (de 1838 a 1945). Tese de doutorado apresentada à UFF, 2013.

DINIZ, Leandro R. A. Mercado de línguas: a instrumentalização brasileira do português como língua estrangeira. Campinas: Editora RG, 2010.

DOMINGUES, Michel G. A.; HENRIQUES, Claudio C. O Pioneirismo de Nascentes e a inauguração dos debates linguísticos no Brasil. In: Revista Brasileira de Filologia, $1^{\circ}$ semestre, 2014. 
DORIA, Escragnolle. Memória Histórica do Colégio Pedro Segundo / Escragnolle Doria; Comissão de Atualização da Memória Histórica do Colégio Pedro II. Roberto Bandeira Accioli et al., Brasília: Instituto Nacional de Estudos e Pesquisas Educacionais, 1997.

ENNIS, Juan. Decir la lengua. Debates ideológico-lingüísticos en Argentina desde 1837. Frankfurt am Main et al., Peter Lang, 2008.

; PFÄNDER, Stefan. Lo criollo en cuestión. Filología e historia. Ciudad Autónoma de Buenos Aires: Katatay, 2013.

FABRO, Ana Paula de Oliveira. O discurso do Diccionario de la lengua española (RAE) em diferentes condições de produção: língua, sujeitos e sentidos. Tese (Doutorado em Língua Espanhola e Literaturas Espanhola e Hispano-Americana) - Faculdade de Filosofia, Letras e Ciências Humanas, Universidade de São Paulo, São Paulo, 2018.

FANJUL, Adrián Pablo. Português - Espanhol: línguas próximas sob o olhar discursivo. São Carlos: Claraluz Editora, 2002.

Proximidad lingüística y memória discursiva. Reflexiones alrededor de un caso. In: Signo \& Seña Número 20. Facultad de Filosofia y Letras UBA, janeiro 2009, pp. 183-205.

"Policêntrico" e "Pan-hispânico". Deslocamentos na vida política da língua espanhola. In: LAGARES, Xoán Carlos; BAGNO, Marcos (org.). Políticas de Norma e conflitos linguísticos. São Paulo: Parábola editorial, 2011.

A pessoa no discurso. Português e espanhol: novo olhar sobre a proximidade. São Paulo: Parábola Editorial, 2017.

; CELADA, Maria Teresa. El español en Brasil. Investigación, enseñanza, políticas. Revista del Instituto de Lingüística. Facultad de Filosofía y Letras. Universidad de Buenos Aires. Número 20, 2009.

; GONZÁLEZ, Neide Maia (orgs.). Espanhol e português brasileiro: estudos comparados. São Paulo: Parábola Editorial, 2014.

FAUSTO, Boris. História Concisa do Brasil. $3^{\mathrm{a}}$ ed. atualizada e ampliada, São Paulo: Editora da Universidade de São Paulo, 2015.

et al. História general da civilização brasileira. Tomo III O Brasil republicano, volume 9. Sociedade e instituições (1889-1930). Rio de Janeiro: Bertrand Brasil, 2006.

; DEVOTO, Fernando J. Brasil e Argentina: um ensaio de história comparada (1850-2002). São Paulo: Editora 34, 2004.

FERREIRA, Rita de Cássia Cunha. A Comissão Nacional do Livro Didático durante o Estado Novo (1937-1945). Dissertação apresentada à Faculdade de Ciências e Letras de Assis, UNESP, para obtenção do título de mestre em História, 2008. 
FONTANELLA DE WEINBERG, B. El español de América. Madrid: Mapfre, 1992.

FOUCAULT, Michel. A Arqueologia do saber. Rio de Janeiro: Forense-Universitária, 1986.

FRAGA, Walter. Pós-abolição; o dia seguinte. In: Schwarcz, Lilia M. e Gomes, Flávio (orgs.)

Dicionário da escravidão e liberdade. $1^{\mathrm{a}}$ ed. São Paulo: Companhia das Letras: 2018.

FREITAS, L. M. A. et al. Relatório final. Niterói: PIBIC/UFF, 2013.

GADET, Françoise e PECHEUX, Michel. A língua inatingível. Campinas: Editora RG, 2010.

GALVES, Charlotte. A Gramática do Português Brasileiro. In: Línguas e Instrumentos linguísticos $\mathrm{n}^{\circ}$ 1. Campinas: Pontes Editores, janeiro/junho, 1998, pp. 79-96.

GENETTE, Gérard. Paratextos Editoriais. Cotia, SP: Ateliê Editorial: 2009.

GIGLIO, C. L. F de Macedo, A compreensão leitora em Manuais de espanhol como língua estrangeira de 1945 a 1990. Dissertação de mestrado, Instituto de Letras da UFF, Niterói, 2006.

GINZBURG, Carlo. Sinais. Raízes de um paradigma indiciário. In: Mitos, emblemas, sinais. Morfologia e história. São Paulo: Cia das Letras, 1989.

GLOZMAN, Mara. Lengua y peronismo: políticas y saberes lingüísticos en la Argentina, 1943-1956. Archivo documental. Ciudad Autónoma de Buenos Aires, Biblioteca Nacional, 2015.

; LAURÍA, Daniela. Voces y Ecos. Una antología de los debates sobre la lengua nacional (Argentina, 1900-2000). Colección Oxímoron: Libros del Museo, 2012.

GOMES, Angela de Castro. Autoritarismo e corporativismo no Brasil: o legado de Vargas. In: REVISTA USP, São Paulo, n.65, março/maio 2005, pp. 105-119.

. O Estado Novo e o debate sobre o populismo no Brasil. In: Sinais Sociais: Rio de Janeiro, v.9 n. 25, maio/agosto 2014, pp. 9-37.

GONZÁLEZ, Neide Maia. Cadê o pronome? O gato comeu. Os pronomes pessoais na aquisição/aprendizagem do espanhol por brasileiros adultos. Tese de doutorado (Programa de Semiótica y Lingüística General), Facultad de Filosofía, Letras y Ciencias Humanas, Universidad de San Pablo, 1994, inédita, disponible em: http://dlm.fflch.usp.br/node/211

GOUVEIA, Regiane. O enigma Latino-Americano: construção de identidades e polarizações entre América Latina e Estados Unidos nos escritos de Martí e Rodó. Dissertação de mestrado. Departamento de História, Pontifícia Universidade Católica do Rio de Janeiro, 2012.

GUIMARÃES, Anselmo. Panaméricas Utópicas: a institucionalização do ensino do espanhol no Brasil (1870-1961). Dissertação apresentada ao Programa de PósGraduação em Educação da Universidade Federal de Sergipe, 2014. 
História dos livros didáticos de espanhol publicados no Brasil (19191961). Tese de doutorado (Programa de Pós-Graduação em Educação - História, Política e Sociedade), Universidade Federal de Sergipe. São Cristovão, Sergipe, 2018.

GUIMARÃES, Eduardo. História da semântica. Sujeito, sentido e gramática no Brasil. Campinas, SP: Pontes, 2004.

Semântica do acontecimento. $2^{\mathrm{a}}$ ed. Campinas, SP: Pontes, 2005.

INDURSKY, Freda (1997). A fala dos quartéis e as outras vozes. Campinas, SP: Editora da Unicamp, 2013.

A memória na cena do discurso. In: ; MITTMANN, Solange; FERREIRA, Maria Cristina Leandro (orgs), Memória e história na/da análise do discurso. Campinas: Mercado de Letras, 2011.

JUSTO, Liborio. Argentina y Brasil en la integración continental. Buenos Aires: Centro Editor de América Latina, 1983.

LAGARES, Xoán Carlos. Apresentação. In: ; BAGNO, Marcos (orgs.): Políticas da Norma e conflitos linguísticos. São Paulo: Parábola Editorial, 2011, pp. 9-14.

LARA, Luis Fernando. Por una redefinición de la lexicografía hispánica. In: Nueva Revista de Filología Hispánica, Tomo XLIV, núm. 2, 1996, pp. 345-364.

LAURIA, Daniela. Reseña: Narvaja de Arnoux, E. y Stefano, M.(eds). Discursividades políticas: en torno de los peronismos. Buenos Aires: Editorial Cabiria (Colección Elementos: indagaciones en prácticas de la cultura), 2017 - 222 p. In: RALED, Vol. 17 (2), 2017, pp. 147-151.

LEFFA, Vilson J. O ensino de línguas estrangeiras no contexto nacional. Contexturas, APLIESP, n. 4, 1999, pp. 13-24.

LESSA, Antônio Carlos. O Barão de Rio Branco e a inserção internacional do Brasil. In: Revista brasileira de política internacional. Vol. 55, nº 1, Brasília, 2012.

LONDRES, Cecília. A Invenção do Patrimônio e a Memória Nacional. In: BOMENY, Helena (org.): Constelação Capanema: intelectuais e políticas. Rio de Janeiro: Editora FGV, 2001, pp. 85-101.

LÓPEZ GARCÍA, María. Representaciones de la variedad rioplatense en manuales de la escuela primaria en Buenos Aires. Tese de doutorado (Facultad de Filosofía y Letras, Universidad de Buenos Aires (UBA)), 2009.

LUCCHESI, Dante. Língua e sociedade partidas: a polarização sociolinguística do Brasil. São Paulo: Contexto, 2015.

LUIS, Carlos Rafael. La Academia Española y la Historia de la Gramática. In: Línguas e Instrumentos lingüísticos $N^{\circ}$ 2. Campinas: Editora Pontes, julho/dezembro, 1998. 
MACEYRA, Horacio. La segunda Presidência de Perón. Buenos Aires: Centro Editor de América Latina, 1984.

MANZIONI, Cecília. Lengua nacional e inmigración: Gámez Marín y Rodó (1912). Trabalho lido em: XVI Congreso de la Sociedad Argentina de Estudios Lingüísticos, UNSAM - Campus Miguelete - Buenos Aires, 3 a 6 de julho de 2018.

MARIANI, Bethania. A redação do Código Civil: polêmica linguística, jurídica ou política? In: LAGARES, Xoán Carlos; BAGNO, Marcos (orgs.): Políticas da Norma e conflitos linguísticos. São Paulo: Parábola Editorial, 2011, pp. 237-257.

; MEDEIROS, Vanise Gomes de. Notícias de duas pesquisas: idéias linguísticas e governo JK. In: Veredas on line. Revista de Estudos Linguísticos, p. 128-144 - PPG LINGÜÍSTICA/UFJF - Juiz de Fora, 1/2007.

Que sentidos de língua nacional para uma nação marcada pelo enunciado "cinqüenta anos em cinco"? In: (org.) Ideias linguísticas. Formulação e circulação no período JK. Rio de Janeiro: Faperj - Campinas: Editora RG, 2010.

MATTOS, Ilmar R. Do Império à República. Estudos Históricos, CPDOC/FGV, 2/4, 1989, pp. 163-171.

MATTOS, T., MEDEIROS, V. O Linguajar Carioca, de Nascentes: Discurso naturalista e dizeres sobre a língua nacional. In: Entremeios: revista de estudos do discurso. v.7, jul/2013. Disponível em: <http://www.entremeios.inf.br>

MATTOSO CÂMARA JR, Joaquim. Dispersos. Rio de Janeiro: Fundação Getúlio Vargas. Antenor Nascentes e a Filologia Brasileira, 1972. In: Revista Brasileira de Filologia, $1^{\circ}$ semestre, 2014.

MENÉNDEZ PIDAL, Ramón. La lengua española. In: Hispania 1, pp. 1-14, 1918.

MONTAGNER, Miguel Ângelo. Trajetórias e biografias: notas para uma análise bourdieusiana. In: Revista Sociologias, Porto Alegre, ano 9, n 17, jan./jun., 2007, pp. 240-264.

MONTALVÃO, Sérgio. Liberdade de ensino versus totalitarismo: a semântica política dos substitutivos de Carlos Lacerda durante a tramitação da Lei de Diretrizes e Bases (19581959). In: Revista de História. São Paulo, No 169, julho/dezembro 2013, pp. 293-322.

MONTEAGUDO, Henrique. Variação e norma linguística: subsídios para uma (re)visão. In: LAGARES, Xoán, BAGNO, Marcos (orgs.) Políticas da Norma e Conflitos Linguísticos. São Paulo: Parábola Editorial, 2011.

NAPOLITANO, Marcos. História do Brasil república: da queda da Monarquia ao fim do Estado Novo. São Paulo: Contexto, 2017.

NASCENTES, Antenor. Um ensaio de phonetica differencial luso-castellana. Dos elementos gregos que se encontram no espanhol. Rio de Janeiro: Typographia do Jornal do Commercio, 1919. 
. O Linguajar Carioca. Rio de Janeiro: Süssekind de Mendonça \&Comp., 1922.

. Gramática da Língua Espanhola para uso dos brasileiros. Rio de Janeiro: Pimenta de Mello, $3^{\mathrm{a}}$ ed, 1934.

A pronúncia brasileira da Língua Portuguesa. In: NETO, Barbadinho (org.), Estudos Filológicos. Volume dedicado à memória de Antenor Nascentes. Rio de Janeiro, Academia Brasileira de Letras, 2003a.

. Língua brasileira. In: , 2003b.

. Carta ao Exmo. Sr. Jorge Guimarães Daupiás. In: 2003c.

. A Filologia Portuguesa no Brasil (Esboço histórico). In: 2003d.

. Leite de Vasconcelos e o Brasil. In: 2003e.

. Figueiredo, esse mal julgado. In: $2003 f$. . Adolfo Coelho e a Etimologia. In: , 2003g. . Vocabulário Ortográfico. In: 2003h.

. Quarenta anos de amizade. In: , 2003i.

NAVARRO MORALES, Emilia; PÔRTO, Leônidas Sobrino. Una experiencia de la enseñanza del español en el Brasil. In: Presente y Futuro de la Lengua Española. Actas de la Asamblea de Filología del I Congreso de Instituciones Hispánicas. Ediciones Cultura Hispánica, Tomo II, Madrid, 1963.

NEEDELL, Jeffrey D. Belle époque tropical: sociedade e cultura de elite no Rio de Janeiro da virada do século. São Paulo: Companhia das Letras, 1993.

NORA, Pierre. Entre Memória e História. A problemática dos lugares. In: Projeto História. Revista do Programa dos estudos pós-graduados de história, v. 10, 1993.

NOVAES, Mariana Gonzales Leandro. Os “Galegos da Galícia” no Rio de Janeiro. Seminário Nacional de Memória Social, Rio de Janeiro, de 8 a 10 de maio de 2013.

NUNES, José Horta. Um espaço ético para pensar os instrumentos linguísticos: o caso do dicionário. In: ORLANDI, Eni P. (org). Políticas Linguísticas no Brasil, Pontes Editores: 2007.

- Uma articulação da Análise de Discurso com a história das Ideias Linguísticas. In: Revista Letras, Santa Maria, v. 18, n² 2, jul/dez 2008, pp. 107-124.

OITICICA, José. Homenagem ao Professor Nascentes. In: NETO, Barbadinho (org.), Estudos Filológicos. Volume dedicado à memória de Antenor Nascentes. Rio de Janeiro, Academia Brasileira de Letras, 2003. 
OLIVEIRA, Lucia Lippi. O intelectual do DIP: Lourival Fontes e o Estado Novo. In: BOMENY, Helena (org.): Constelação Capanema: intelectuais e políticas. Rio de Janeiro: Editora FGV, 2001, pp. 37-58.

OLIVEIRA LIMA, Manoel de. América Latina e América Inglesa. A evolução brasileira comparada com a hispano-americana e com a anglo-americana. Rio de Janeiro: Garnier, s/d. (publicação de seis conferências pronunciadas originalmente na Universidade de Stanford, EUA, em outubro de 1912).

Impressões da América Espanhola (1904-1906). Rio de Janeiro: Livraria José Olympio Editora, 1953. Irmãos, 1920.

. Na Argentina (impressões 1918-19). São Paulo; Rio de Janeiro: Weiszflog . Pan-americanismo (Monroe, Bolívar, Roosevelt). Brasília: Senado Federal; Rio de Janeiro: Fundação Casa de Rui Barbosa, 1980 (1a. ed. de 1907).

ORLANDI, Eni P. A língua imaginária e a língua fluida: dois métodos de trabalho com a linguagem. In: Pontes, 1988. (org.) Política linguística na América Latina. Campinas, SP:

. Vão surgindo sentidos. In: ORLANDI, Eni P. (org). Discurso Fundador: a formação do país e a construção da identidade nacional. Campinas, SP: Pontes, 1993.

História das idéias linguísticas. Construção do saber metalingüístico e constituição da Língua nacional. Campinas, São Paulo: Pontes; Cáceres, MT: Unemat Editora, 2001.

. Língua e conhecimento linguístico: para uma História das Ideias no Brasil. São Paulo: Cortez, 2002.

(1999). Análise do discurso: princípios e procedimentos, $7^{\mathrm{a}}$ ediç̧ão, Campinas, São Paulo: Pontes, 2007.

Terra à vista. Discurso do confronto: velho e novo mundo. $2^{\mathrm{a}}$ ed.

Campinas: Editora da Unicamp, 2008.

PAYER, Maria Onice. Memória da língua. Imigração e Nacionalidade. São Paulo: Ed. Escuta, 2006.

PÊCHEUX, Michel. Remontemos de Foucault a Spinoza. Comunicação de Pêcheux no Simpósio do México sobre "Discurso Político: teoria e análise”, realizado de 07 a 11/11/1977.

O discurso: estrutura ou acontecimento. Campinas, SP: Pontes Editora, 2008.

- Papel da Memória. In: ACHARD, Pierre et al. Papel da Memória. Campinas: Pontes, 2010a. 
(1969). A análise automática do discurso (AAD-69). Parte I (Trad. Eni Orlandi) In: GADET, F. e HAK, T. (orgs.). Por uma análise automática do discurso. Uma introdução à obra de Michel Pechêux. Campinas: Editora da UNICAMP, 2010b, pp. 61-105.

. Ler o arquivo hoje. In: Eni P. Orlandi (org.). Gestos de leitura: da história no discurso. $3^{\mathrm{a}}$ ed. Campinas, SP: Editora da Unicamp, 2010c.

(1975). Semântica e Discurso. Uma crítica à afirmação do óbvio. $4^{\mathrm{a}}$ ed. Campinas: Ed. UNICAMP, 2009.

; Fuchs, Catherine (1975). A propósito da análise automática do discurso: atualização e perspectivas. In: In: GADET, F. e HAK, T. (orgs.). Por uma análise automática do discurso. Uma introdução à obra de Michel Pechêux. Campinas: Editora da UNICAMP, 2010, pp. 159-249.

PEIXOTO, Fernanda Áreas. A Viagem como Vocação: Itinerários, Parcerias e Formas de conhecimento, São Paulo: FAPESP/Editora da Universidade de São Paulo, 2015.

PICANÇO, D. C. de Lima. História, Memória e Ensino de Espanhol no Brasil (19421990). Curitiba: Ed da UFPR, 2003.

PONTE, Andrea. Prefácio. In: Dez anos da “Lei do Espanhol” (2005-2015). Belo Horizonte: UFMG, 2016.

PRADO, Maria Ligia Coelho. O Brasil e a distante América do Sul. Revista de História 145, 2001, pp. 127-149.

Davi e Golias: as relações entre Brasil e Estados Unidos no século XX. In: MOTA, Guilherme (org.) Viagem incompleta. A experiência brasileira (1500-2000). Editora SENAC: São Paulo, 2000, pp. 319-347.

QUINTELA, Anton Corbacho; Da COSTA, Alexandre Ferreira. A filologia de Antenor Nascentes e o início, no Brasil, da Linguística Aplicada ao ensino de espanhol. In: Revista SIGNÓTICA, Programa de Pós-Graduação em Letras e Linguística da Universidade Federal de Goiás, v. 25, n. 2, 2013. Disponível em: www.revistas.ufg.br/sig/article/view/24629.

RAMOS, Jorge Abelardo. Historia de la Nación Latinoamericana. Buenos Aires: Ed. Peña Lillo Ediciones Continente, $1^{\mathrm{a}}$ ed, 1968.

RAPOPORT, Mario; MADRID, Eduardo. Os países do Cone Sul e as grandes potências. In: CERVO, Amado Luiz, RAPOPORT, Mario (orgs.). História do Cone Sul. Rio de Janeiro: Revan, Brasilia: Editora Universidade de Brasilia, 1998, pp. 239-288.

RECUERO, Ana L. Pederzolli Cavalheiro. Por que (não) ensinar espanhol no Brasil? As políticas linguísticas e a gramatização no ensino do espanhol a partir da glotopolítica. Tese de doutorado (Universidade Federal de Santa Maria (RS)), 2017. 
REIS, Mateus Favaro. Americanismo(s) no Uruguai: os olhares entrecruzados dos intelectuais sobre a América Latina e os Estados Unidos (1917-1969). Dissertação de Mestrado (Programa de Pós-graduação em História), Universidade Federal de Minas Gerais, 2008.

REIS, João José. "Nos achamos em campo a tratar da liberdade": a resistência negra no Brasil oitocentista.. In: MOTA, Carlos Guilherme (org.). Viagem incompleta. A experiência brasileira (1500-2000). Formação: histórias. São Paulo: Editora SENAC São Paulo, 2000, pp. 241-263.

REVEL, Jaques. Microanálise e construção do social. In: (org.). Jogos de Escala. A experiência da microanálise. Rio de Janeiro: Editora da Fundação Getúlio Vargas, 1998.

RIBEIRO, Manoel. Editorial. In: Revista Brasileira de Filologia, $1^{\circ}$ semestre, 2014.

RODRIGUES, Fernanda dos Santos Castelano. Língua viva, letra morta. Obrigatoriedade e ensino de espanhol no arquivo jurídico e legislativo brasileiro. São Paulo: Humanitas, 2012.

Reflexões da Operação Pan-Americana nos projetos de JK para a educação nacional: um lugar para o espanhol. In: Mariani, B; Medeiros, V (orgs). Ideias LInguísticas: formulação e circulação no período JK. Rio de Janeiro: Faperj Campinas: Editora RG, 2010.

SAMPAIO, Rita. O livro didático e o cânone literário-escolar (1930-1945). Dissertação de mestrado (Programa de Pós-Graduação em Educação), Faculdade de Educação da Universidade de São Paulo, 2010.

SAMPAIO MALAN, Pedro. Relações econômicas internacionais do Brasil (19451964). In: FAUSTO, Boris (org), História Geral da Civilização Brasileira, Tomo III, O

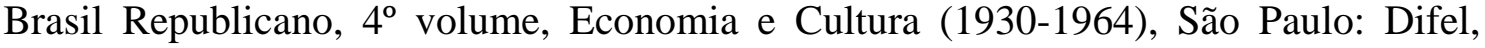
1984, pp. 51-106.

SÁNCHEZ, Aquilino Pérez. Historia de la enseñanza del español como lengua extranjera. Madrid: Editora Sgel, 1992.

SANTOS, Ademir Valdir dos. A política educacional nacionalista e o aspecto linguístico: vestígios na escola primária. In: Rev. Brasileira de Est. Pedag. Brasília v. 90 n. 225, maio/agosto 2009, pp. 511-527.

SARLO, Beatriz. Escenas de la vida posmoderna: intelectuales, arte y videocultura en la Argentina. Buenos Aires: Ariel, 1994.

SCHWARCZ, Lilia M. Lima Barreto: triste visionário. São Paulo: Companhia das Letras, 2017.

Teorias Raciais. In: ; GOMES, Flávio (orgs.). Dicionário da Escravidão e Liberdade: 50 textos críticos. São Paulo: Companhia das Letras, 2018, pp. 403-408. 
Letras, 2015.

; STARLING, Heloisa M. Brasil: uma biografia. São Paulo, Companhia das

; GOMES, Flávio (orgs.). Dicionário da Escravidão e Liberdade: 50 textos

críticos. São Paulo: Companhia das Letras, 2018.

SCHWARTZMAN, Simon; BOMENY, Helena; COSTA, Vanda. Tempos de Capanema. Rio de Janeiro: Paz e Terra, São Paulo: Edusp, 1984.

SEGISMUNDO, Fernando. Memória de estudante (Colégio Pedro II). Edições comemorativas do sesquicentenário. Rio de Janeiro: Editora Brasil-América (EBAL), 1987.

SEPÚLVEDA, Isidro. El sueño de la Madre Patria. Hispanoamericanismo y nacionalismo. Madrid: Marcial Pons, 2005.

SERRANI-INFANTE, Silvana. Análise de ressonâncias discursivas em micro-cenas para estudo da identidade linguístico-cultural. In: Trabalhos de Linguística Aplicada, Campinas (24), Jul/Dez, 1994, pp. 79-90.

SEVCENKO, Nicolau. A revolta da vacina: mentes insanas em corpos rebeldes. São Paulo: Editora Scipione, 1993.

SILVA, Ana Maria da. Itinerários da Produção Intelectual de Antenor de Veras Nascentes na Comunicação Científica. Dissertação de mestrado (Ciências da Informação. Instituto Brasileiro de Informação em Ciência e Tecnologia e Universidade Federal do Rio de Janeiro). Rio de Janeiro, 2012.

SINGER, Paul. Interpretação do Brasil: uma experiência histórica de desenvolvimento. In: FAUSTO, Boris (diretor). História Geral da Civilização Brasileira. III O Brasil Republicano, 4 Economia e Cultura (1930-1964), capítulo iv, São Paulo: Difel / Difusão Editorial S.A., 1984, pp. 209-245.

SOKOLOWICZ, Laura. Livros didáticos em revista (1990-2010). Sujeito, linguagem, discurso e ideologia no ensino de espanhol como língua estrangeira no Brasil. Dissertação de mestrado. Universidade de São Paulo, 2014. Disponível em: http://www.teses.usp.br/teses/disponiveis/8/8145/tde-17042015-182950/

A gramatização do espanhol no Brasil (1990-2015): a configuração de mercados hegemônicos. In: SOUSA, Socorro C. T.; SOUSA, Emny N. B.; Ponte, Andrea S. (Orgs.). Fotografias de política linguística: um panorama das pesquisas na pós-graduação brasileira. João Pessoa: Editora da UFPB, 2019.

SOUZA, Maria do Carmo Campello de. O processo político partidário na primeira república. In: MOTA, Carlos Guilherme (org.), Brasil em perspectiva, difusão européia do livro, São Paulo, 1968, pp. 162-226.

TOSI, Carolina. Escritos para enseñar. Ciudad autónoma de Buenos Aires: Paidós, 2018. 
VENTURA, Roberto. Um Brasil mestiço: raça e cultura na passagem da monarquia à república. In: MOTA, Carlos Guilherme (org.). Viagem incompleta. A experiência brasileira (1500-2000). Formação: histórias. São Pauloditora SENAC São Paulo, 2000, pp. 329-359.

VIEIRA, Priscila Oliveira. ¿Español sin fronteras? Ou entre as fronteiras projetadas pelo imaginário e pelo real? Dissertação de mestrado (Programa de Língua Espanhola e Literaturas Espanhola e Hispano-americana), FFLCH, São Paulo, 2012.

VILLA, Laura. La oficialización del español en el siglo XIX. La autoridad de la Academia. In: Del Valle, J. (ed.) Historia política del español. La creación de una lengua, Madrid: Aluvión editorial, 2015 (1ª versão em espanhol), pp. 107-121.

VISCARDI, Cláudia M. R. O Federalismo Oligárquico brasileiro: uma revisão da política do café com leite. In: Anuario IEHS (Buenos Aires), Tandil, Argentina, v. 16, 2001, pp. 73-90.

WESTPHALEN, Maria Cecília. Introdução. In: VECHIA, A.; LORENZ, K.M. Programas de ensino da escola secundária brasileira: 1850-1951. Curitiba: Ed. do Autor, 1998.

ZOPPI-FONTANA, Mónica Graciela. Cidadãos modernos: discurso e representação política. Campinas, SP: Editora da UNICAMP, 1997.

ZOTTI, Solange Aparecida. O ensino secundário nas reformas Francisco Campos e Gustavo Capanema: um olhar sobre a organização do currículo escolar. In: Anais do IV Congresso Brasileiro de História da Educação. Goiânia: Universidade Católica de Goiás / SBHE, 2006.

\section{DOCUMENTOS / ARQUIVO JURÍDICO-LEGISLATIVO}

BRASIL. Lei 3.674 de 7 de janeiro de 1919. Fixa a despesa geral da República dos Estados Unidos do Brasil para o exercício de 1919.

BRASIL. Ministério da Justiça e Negócios Interiores. Programas de ensino da cadeira de espanhol aprovado em 5 de abril de 1919. Diário Oficial da União. Rio de Janeiro, DF, 5 de jul. de 1919.

BRASIL. Reforma Francisco Campos: Decreto $n^{\circ}$ 19.890. Diário Oficial da União. Rio de Janeiro, 18 de abril de1931. Disponível em:

https://www2.camara.leg.br/legin/fed/decret/1930-1939/decreto-19890-18-abril-1931504631-publicacaooriginal-141245-pe.html

BRASIL. Exposição de Motivos da Reforma Capanema: Decreto Lei $\mathrm{n}^{0} 4.244$ (por Gustavo Capanema), de 1 de abril de 1942, Rio de Janeiro, 1942a. Disponível em: https://www2.camara.leg.br/legin/fed/declei/1940-1949/decreto-lei-4244-9-abril-1942414155-133712-pe.html 
BRASIL. Decreto-Lei 4.244 de 9 de abril de 1942. Lei orgânica do ensino secundário, Rio de Janeiro, 1942b. Disponível em:

https://www2.camara.leg.br/legin/fed/declei/1940-1949/decreto-lei-4244-9-abril-1942-

414155-publicacaooriginal-1-pe.html

BRASIL. Portaria Ministerial $n^{\circ}$ 127, de 3 de fevereiro de 1943. Rio de Janeiro:

Ministério de Estado da Educação e Saúde, 1943. Disponível em:

https://www.jusbrasil.com.br/diarios/2162571/pg-11-secao-1-diario-oficial-da-uniao-

dou-de-05-02-1943.

BRASIL. Projeto de Lei 4.606, 1958. Altera o Decreto-lei $\mathrm{n}^{\circ} 4.244$, de 9 de abril de 1942, no que se refere ao aprendizado do idioma espanhol nos dois ciclos de ensino secundário. Do poder executivo à comissão de educação da Câmara dos Deputados.

BRASIL. Lei 4.024 de 20 de dezembro de 1961. Fixa as diretrizes e bases da educação nacional. Disponível em:

https://www2.camara.leg.br/legin/fed/lei/1960-1969/lei-4024-20-dezembro-1961-

353722-publicacaooriginal-1-pl.html

\section{GRAMÁTICAS E MANUAIS}

ALONSO, Amado; UREÑA, Pedro Henríquez. Gramática Castellana - segundo curso. Buenos Aires: Editorial Losada, 25 a ed., 1975.

ÁLVAREZ CALLEJA, José Ramón. Español Básico. Editora do Brasil S/A. São Paulo, Rio de Janeiro, Belo Horizonte, Salvador, Recife, Curitiba, Porto Alegre, [1946]1952.

BARROS, Aristóteles de Paula. Español. Gramática, literatura y antología. São Paulo: Edições Melhoramentos, 1948.

BECKER, Idel. Compêndio de Literatura Espanhola e Hispano-Americana. São Paulo, Rio de Janeiro, Recife, Bahia, Pará, Porto Alegre, 1943.

. Dicionário Espanhol-Português, Português-Espanhol. São Paulo: Livraria Nobel, [1943] 1979.

. Manual de espanhol. $1^{\text {a }}$ ed. São Paulo, Rio de Janeiro, Recife, Bahia, Pará, Porto Alegre: Companhia Editora Nacional, 1945.

Manual de español. $5^{a}$ ed. São Paulo, Rio de Janeiro, Recife, Bahia, Pará, Porto Alegre: Companhia Editora Nacional, 1947.

. Manual de español. 16 ed. São Paulo: Companhia Editora Nacional, 1953.

. Manual de español. 26a ed. São Paulo: Companhia Editora Nacional, 1955.

. Manual de español. 44a ed. São Paulo: Companhia Editora Nacional, 1961.

. Manual de español. 73a ed. São Paulo: Nobel, 1986. 
. Manual de español. 76a ed. São Paulo: Nobel, 1988.

GIUSTI, Roberto F. Gramática y ejercicios de idioma. Primer Curso. Buenos Aires: Angel Estrada Editores S.A., 24 edição, 1956.

GOLDSCHMIDT, Berthold. Noções práticas da Língua Allemãa. Leipzig: F.A. Brockhaus. Livreiro de S.M o Imperador do Brasil, 1859.

. Noções teóricas da Língua Allemãa. Leipzig, 1960.

JUCÁ FILHO, Cândido. El castellano contemporáneo (gramática y textos). Rio de Janeiro: Editora Pan-americana, 1944.

LAGOMARSINO, Raul G. Gramática Castellana. Porto Alegre: Edições A Nação, 1944.

MONAT, Henrique; RUCH, Gastão. Curso Graduado de Língua franceza. Methodo pratico para aprender a língua franceza. Rio de Janeiro: Livraria Francisco Alves (distribuição em São Paulo e Minas), 1901.

NASCENTES, Antenor. Gramática da Língua Espanhola para uso dos brasileiros. Rio de Janeiro: Pimenta de Mello, $3^{\text {a }}$ ed., 1934.

- Um ensaio de phonetica diferencial luso-castelhana - Dos elementos gregos que se encontram no espanhol. Rio de Janeiro, 1919.

POZO Y POZO, Adolfo. Gramática española. Rio de Janeiro, São Paulo, Belo Horizonte: Livraria Francisco Alves, 1943.

SAID ALI. Advertência. In: Primeiras Noções de Grammatica Franceza, pelo Dr Carlos Ploetz. Obra traduzida do allemão e adaptada à língua portuguesa por M. Said Ali. Rio de Janeiro: Livraria Francisco Alves, 21ª ed, 1935.

SOLANA, Vicente; MORAIS, Bento Bueno de. Gramática castellana. São Paulo: Edições e Publicações Brasil. 